\title{
Reguły polityki pieniężnej w Polsce Podejście ilościowe
}


盗 


\section{Reguły polityki pieniężnej w Polsce Podejście ilościowe}

Paweł Baranowski

ŁÓDZKIEGO

ŁÓDŹ 2014 
Paweł Baranowski - Uniwersytet Łódzki, Wydział Ekonomiczno-Socjologiczny Katedra Ekonometrii, 90-214 Łódź, ul. Rewolucji 1905 r. nr 39

\section{RECENZENT}

Michat Brzoza-Brzezina

REDAKTOR WYDAWNICTWA UŁ

Elżbieta Marciszewska-Kowalczyk

SKŁAD I ŁAMANIE

AGENT PR

OKŁADKĘ PROJEKTOWAŁA

Karolina Józwik

C Copyright by Uniwersytet Łódzki, Łódź 2014

Wydane przez Wydawnictwo Uniwersytetu Łódzkiego

Wydanie I. W.06317.13.0.H

ISBN (wersja drukowana) 978-83-7969-070-1

ISBN (ebook) 978-83-7969-202-6

Wydawnictwo Uniwersytetu Łódzkiego

90-131 Łódź, ul. Lindleya 8

www.wydawnictwo.uni.lodz.pl

e-mail: ksiegarnia@uni.lodz.pl

tel. (42) 6655863 , faks (42) 6655862 


\section{SPIS TREŚCI}

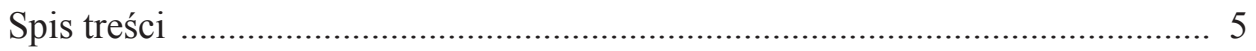

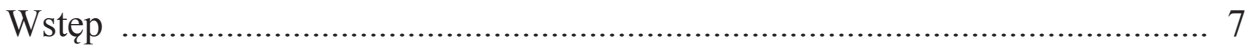

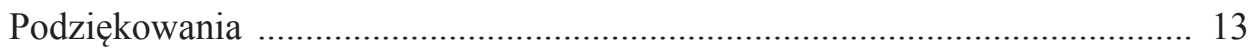

1. Wybrane kategorie i metody opisu polityki pieniężnej ................................. 14

Niespójność polityki pieniężnej w czasie ................................................... 14

Reguły polityki pieniężnej .................................................................... 16

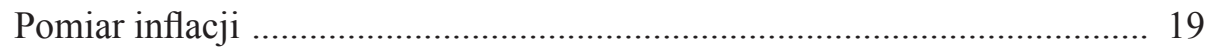

Pomiar luki produkcyjnej ...................................................................... 26

Uogólniona metoda momentów .............................................................. 28

Załącznik 1.1. Model niespójności polityki gospodarczej Kydlanda

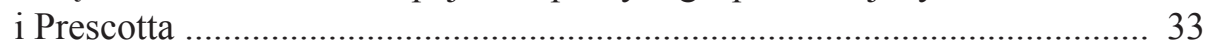

Załącznik 1.2. Niespójność polityki pieniężnej w modelach Barro

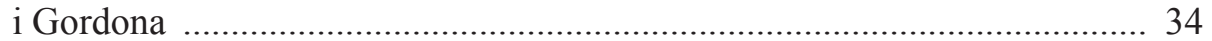

2. Reguła Taylora oraz jej rozszerzenia - przegląd badań .............................. 37

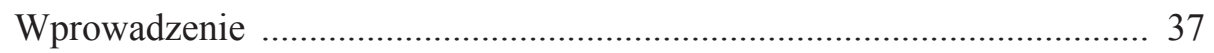

Reguła stopy procentowej J.B. Taylora ………..................................... 37

Reguła Taylora - przegląd dotychczasowych badań .................................. 38

Zastosowania reguły Taylora ............................................................... 54

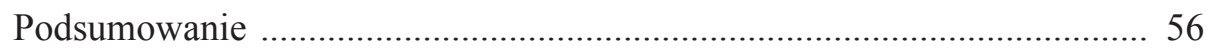

3. Reguła Taylora dla Polski - adaptacyjna, bieżąca i antycypacyjna ............ 59

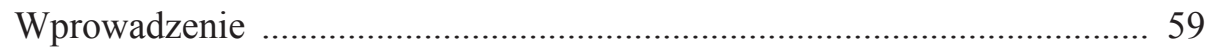

Reguła Taylora dla Polski - analizowane warianty ..................................... 59

Podejście data-rich w analizie reguł polityki pieniężnej ............................. 61

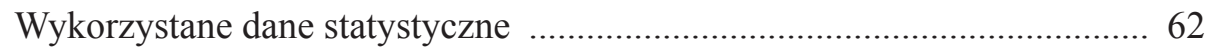

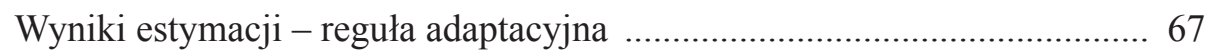

Wyniki estymacji - reguła bieżąca .......................................................... 69

Wyniki estymacji - reguła antycypacyjna .............................................. 70

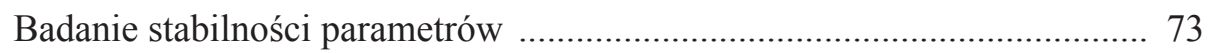




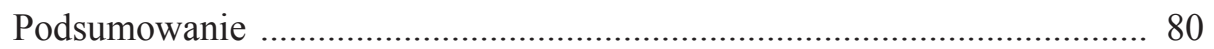

Załącznik 3.1. Opis zmiennych użytych do analizy czynnikowej .............. 82

Załącznik 3.2. Wrażliwość wyników - reguła adaptacyjna ........................ 83

Załącznik 3.3. Wrażliwość wyników - reguła antycypacyjna ..................... 84

Załącznik 3.4. Wrażliwość wyników - luka produkcyjna wyznaczona

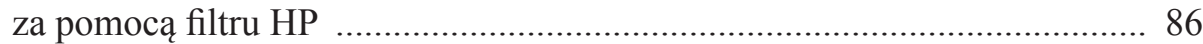

4. Oczekiwane i nieoczekiwane zacieśnienie polityki pieniężnej dla gospodarki Polski - analiza w warunkach różnych reguł ...................... 87

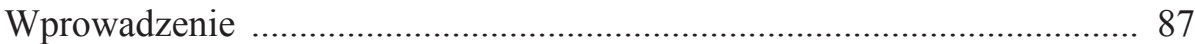

Modele DSGE - uwagi ogólne ............................................................. 88

Podstawy teoretyczne i specyfikacja modelu ............................................... 90

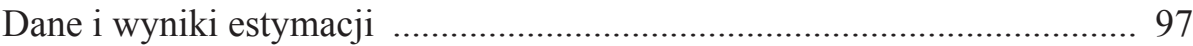

Badanie stabilności parametrów ............................................................ 100

Rozwiązanie modelu i założenia symulacji - uwagi ogólne ..................... 103

Wyniki symulacji - reguła adaptacyjna _.............................................. 107

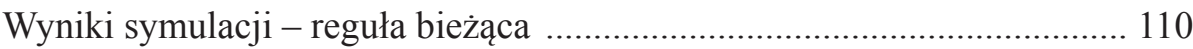

Wyniki symulacji - reguła antycypacyjna .............................................. 112

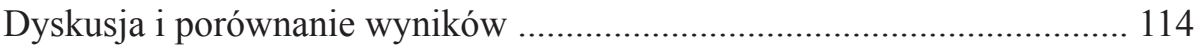

Symulacja w warunkach ,przełączania reguł” ............................................ 121

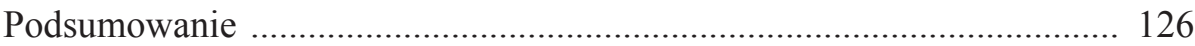

Załącznik 4.1. Wyprowadzenie równania hybrydowej krzywej IS .......... 128

Załącznik 4.2. Wyprowadzenie równania hybrydowej krzywej Phillipsa ... 129

Załącznik 4.3. Analiza wrażliwości funkcji reakcji na szok polityki

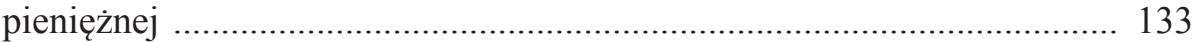

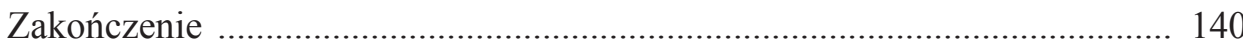

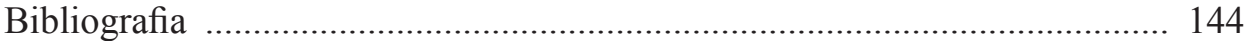

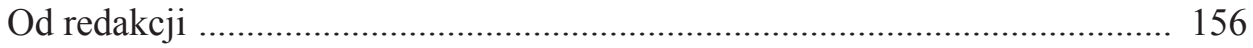




\section{WSTEPP}

Powszechnie uznanym nadrzędnym celem polityki pieniężnej jest zapewnienie stabilnej siły nabywczej pieniądza poprzez utrzymanie niskiej inflacji, a w miarę możliwości również łagodzenie wahań koniunktury gospodarczej. Takie cele ustanowiono m.in. dla Narodowego Banku Polskiego oraz Europejskiego Banku Centralnego.

Kluczowa część dyskusji o polityce pieniężnej dotyczy sposobu realizacji tych celów. Ekonomiści przez długi czas spierali się m.in. o to, czy bank centralny powinien działać wedle stałych reguł, czy też w sposób uznaniowy. Wydaje się, że od czasu przedstawienia przez Kydlanda i Prescotta (1977) problemu niespójności polityki gospodarczej w czasie i reguł jako jednego z możliwych rozwiązań, przeważa pogląd o korzyściach ze stosowania reguł.

Do połowy lat osiemdziesiątych XX wieku analizy reguł polityki pieniężnej ograniczały się niemal wyłącznie do reguł celów, które można utożsamiać ze strategiami polityki pieniężnej (deklaracjami banku centralnego co do sposobu długofalowej kontroli realizacji jego celów). W późniejszych pracach zwrócono uwagę na reguły opisujące kształtowanie się instrumentów banku centralnego. Największą popularność zyskał prosty model opisujący nominalną stopę procentową w zależności od inflacji i luki produkcyjnej, zaproponowany przez J.B. Taylora (1993) oraz jego rozszerzenia. Reguły tego typu stanowią najczęściej spotykany sposób opisu polityki pieniężnej we współczesnych modelach makroekonomicznych, w tym w nowokeynesistowskich modelach dynamicznej stochastycznej równowagi ogólnej (DSGE), wykorzystywanych również w niniejszej pracy.

Coraz dłuższe szeregi czasowe, licząc od wprowadzenia strategii bezpośredniego celu inflacyjnego, umożliwiają bardziej precyzyjną ilościową analizę polityki pieniężnej. Głównym celem książki jest więc ekonometryczna analiza reguł polityki pieniężnej w Polsce w okresie realizacji strategii bezpośredniego celu inflacyjnego (od 1999 roku). W pracy argumentujemy, że restrykcyjność polityki pieniężnej może być wyrażona za pomocą nominalnej rynkowej stopy procentowej o krótkim okresie zapadalności. Stopę tę modelujemy za pomocą rozszerzeń reguły Taylora.

Główne pytania badawcze, na które próbujemy odpowiedzieć, brzmią następująco:

1. W jaki sposób nominalna stopa procentowa - główna miara stopnia restrykcyjności polskiej polityki pieniężnej, reaguje na zmiany inflacji i luki produkcyjnej? 
2. Jak zmienia się inflacja i luka produkcyjna w Polsce pod wpływem szoku polityki pieniężnej - rozumianego jako krótkookresowe podwyższenie stopy procentowej ponad wartość wynikającą z reguły?

Powyższe pytania badawcze dotyczą więc kształtu reguł w Polsce oraz skutków krótkookresowego odejścia od tych reguł.

Uszczegółowieniem pierwszego pytania badawczego są następujące hipotezy:

H1) wzrost inflacji i luki produkcyjnej powoduje wzrost stopy procentowej,

H2) występuje mechanizm wygładzania stóp procentowych,

H3) parametry reguły stopy procentowej są stabilne w czasie.

Pewną trudność w poszukiwaniu odpowiedzi na te pytania i weryfikacji postawionych hipotez sprawia fakt, że przedstawiciele banków centralnych (w tym członkowie ciał decyzyjnych) niechętnie wypowiadają się co do stosowanych przez nich reguł instrumentów, w szczególności do tego czy decyzje dotyczące polityki pieniężnej podejmowane są z wykorzystaniem: przeszłych, bieżących czy oczekiwanych wartości zmiennych makroekonomicznych. Specyfikacji dynamicznej równań reguł instrumentów nie możemy również określić na podstawie przesłanek teoretycznych. Co ciekawe, również w modelach DSGE, gdzie równania opisujące zmienne makroekonomiczne ściśle wynikają $\mathrm{z}$ formalnego rozwiązania problemów optymalizacji pojedynczych mikropodmiotów, w zdecydowanej większości przypadków działalność banku centralnego opisują reguły o specyfikacji przyjmowanej ad hoc.

Z tego względu analizy prowadzimy wielowariantowo - spośród wielu modyfikacji reguły Taylora, do estymacji i porównania wybieramy następujące postacie reguł:

a) adaptacyjną - z opóźnioną inflacją i luką produkcyjną (backward looking),

b) bieżącą $-\mathrm{z}$ bieżącą inflacją i luką produkcyjną,

c) antycypacyjną - z przyszłą, oczekiwaną inflacją i luką produkcyjną (forward looking).

Dokonując porównania otrzymanych wyników dla poszczególnych wariantów, skupiamy się na analizie odpowiedzi na szok polityki pieniężnej. Stawiamy w tym przypadku następującą hipotezę badawczą:

H4) skutki szoku polityki pieniężnej dla inflacji i luki produkcyjnej różnią się znacząco, w zależności od przyjętej reguły.

Po omówieniu zamierzeń badawczych możemy umieścić je na tle literatury przedmiotu. Reguły polityki pieniężnej oparte o koncepcję zaproponowaną przez Taylora były wykorzystywane w licznych badaniach empirycznych i teoretycznych (przegląd najważniejszych znajduje się w rozdz. 2). Nowokeynesistowskie 
modele typu DSGE, w formie zbliżonej do tej jaką stosujemy w pracy, są znane od końca lat dziewięćdziesiątych XX wieku (Clarida, Gali, Gertler, 1999). Reguła Taylora lub jej modyfikacje stanowią najczęściej spotykaną kotwicę nominalną modeli DSGE, sprowadzającą modelowaną gospodarkę do punktu długookresowej równowagi (zob. np. Woodford, 2003; Gali, 2008). Jak sądzimy, wartością dodaną pracy jest oszacowanie trzech wariantów reguł dla gospodarki Polski, a następnie porównanie skutków szoku polityki pieniężnej w ramach modelu DSGE małej skali, w zależności od reguły. Według naszej wiedzy, poza wkładem o charakterze empirycznym (oszacowanie reguł i pozostałych równań modeli DSGE dla gospodarki Polski), nowością jest również zbadanie skutków szoku oczekiwanego w zależności od każdej z trzech przyjętych specyfikacji reguły. W literaturze krajowej i zagranicznej badania skutków szoku oczekiwanego są wciąż rzadko spotykane i nie znajdujemy wśród nich analiz z użyciem różnych reguł (zob. np. Schmitt-Grohe, Uribe, 2009, 2012; Milani, Treadwell, 2011). Nowym elementem są również symulacje modelu, w którym dopuszczamy „przełączanie” reguły Taylora - dotychczasowe badania uwzględniały jedynie zmiany parametrów a nie zmiany specyfikacji dynamicznej reguły (zob. np. Davig, Leeper, 2007). W literaturze polskiej nowe elementy obejmują również: reinterpretację modelu DSGE z podmiotami nieoptymalizującymi (wzorowanego na pracy: Amato, Laubach, 2003) oraz wielowariantowe badanie skutków szoku polityki pieniężnej.

Czynimy również następujące komentarze do użytych metod badawczych.

Po pierwsze - w książce unikamy analiz o charakterze normatywnym, które mogłyby sprawić wrażenie dawania ,prostych recept” co do sposobu prowadzenia polityki pieniężnej. Reguły stopy procentowej nigdy nie mają charakteru ścisłego, lecz stanowią opis „,komponentu systematycznego” polityki pieniężnej (od którego dopuszcza się odchylenia). Innym naturalnym ograniczeniem jest warunkowość analiz (zarówno ekonomicznych, jak i ekonometrycznych) ze względu na przyjęty model. $Z$ tego względu, naszym zdaniem, analizy modelowe prezentowane w niniejszym opracowaniu nie mogą w pełni opisać w jaki sposób była prowadzona polityka pieniężna (odpowiedź na pierwsze pytanie badawcze, co do kształtu reguł) oraz jakich zmian luki produkcyjnej i inflacji możemy oczekiwać na skutek krótkookresowego odejścia od reguły (odpowiedź na drugie pytanie badawcze, co do skutków szoku polityki pieniężnej). Próbą zobiektywizowania wniosków są dodatkowe analizy, które miały na celu przedstawienie odporności ${ }^{1}$ wyników.

Po drugie - podstawą analiz prowadzonych w rozdziale 4 jest model DSGE. W modelach tego typu przyjmuje się, że gospodarstwa domowe i przedsiębiorstwa zachowują się tak, jak wynika z rozwiązania matematycznego problemu maksymalizacji użyteczności lub zysku. W prezentowanym modelu częściowo uchylamy te założenia, poprzez uwzględnienie podmiotów nieoptymalizujących.

\footnotetext{
${ }^{1}$ Mamy tu na myśli odpowiednik angielskiego słowa robustness.
} 
Jednocześnie model ten zawiera jedynie podstawowe mechanizmy występujące w gospodarce. Abstrahuje się w nim od zagadnień gospodarki otwartej, niemal całkowicie pomija się rynek pracy i rynki finansowe, a także upraszczająco zakłada się, że kształtowanie się produkcji w długim okresie może być opisane w sposób egzogeniczny, za pomocą deterministycznego trendu. Mamy nadzieję, że prostota przyjętego modelu jest nie tylko ograniczeniem, ale i zaletą. Pozwala bowiem z jednej strony na dokonanie przejrzystej oceny ekonomicznej i interpretacji wyników symulacji, a z drugiej strony - ułatwia analizy empiryczne, dzięki mniejszej liczbie parametrów (co ma znaczenie w kontekście stosunkowo krótkiej próby - 55 kwartałów, licząc od wprowadzeniu strategii bezpośredniego celu inflacyjnego).

Po trzecie - w książce koncentrujemy się na tradycyjnie rozumianej funkcji polityki pieniężnej, jaką jest utrzymanie niskiej i stabilnej inflacji oraz stabilizacja cyklu koniunkturalnego. Od czasów kryzysu finansowego w 2008 roku, tak rozumiane cele polityki pieniężnej częściowo straciły na znaczeniu, na rzecz stabilności szeroko rozumianego systemu finansowego (tzw. polityka makroostrożnościowa). W przeciwieństwie do krajów z bardziej rozwiniętym sektorem finansowym, Polska nie doświadczyła tak silnych skutków kryzysu, co spowodowało, że NBP nie stosował na szeroką skalę nadzwyczajnych instrumentów polityki pieniężnej. Wydaje się więc, że pominięcie elementów polityki makroostrożnościowej nie zmniejsza wartości prowadzonych badań.

Przyjęto następujący układ pracy.

Pierwszy rozdział stanowi wprowadzenie do zagadnień i metod stosowanych w książce. Przedstawione tu treści mają głównie na celu prezentację tematu pracy i motywacji dla podjęcia badań nad regułami oraz zrelacjonowanie Czytelnikowi kilku najważniejszych ,szczegółów technicznych” używanych w kolejnych częściach pracy. W szczególności podejmujemy kwestię niespójności polityki pieniężnej w czasie oraz reguły tejże polityki (jako jednego z jego rozwiązań). Ponadto przedstawiamy metody pomiaru dwu najważniejszych zmiennych warunkujących politykę pieniężną, tj. inflacji i luki produkcyjnej. Opierając się na tej prezentacji dokonamy wyboru metod pomiaru, które wykorzystujemy w dalszej części pracy. Przedstawiamy również uogólnioną metodę momentów, z której korzystamy w celu oszacowania parametrów antycypacyjnej reguły Taylora (w rozdz. 3) oraz pozostałych równań modelu DSGE (w rozdz. 4).

W rozdziale drugim szerzej omawiamy regułę zaproponowaną przez J.B. Taylora oraz dokonujemy krytycznego przeglądu badań wykorzystujących tę koncepcję. Przegląd ten pozwala określić sposób, w jaki przeprowadzamy empiryczną weryfikację reguł w kolejnym rozdziale. Na tej podstawie zdecydowaliśmy, że miarą restrykcyjności polityki pieniężnej jest nominalna rynkowa stopa procentowa o krótkim okresie zapadalności. W wyjściowych postaciach reguł wprowadzimy mechanizm wygładzania stóp procentowych, co pozwala uwzględnić 
awersję banku centralnego do gwałtownych zmian tego instrumentu polityki pieniężnej i zweryfikować hipotezę H2.

Trzeci rozdział zawiera wyniki estymacji reguł stopy procentowej, wywodzących się z koncepcji reguły Taylora poszerzonych o wygładzanie stóp procentowych. Korzystając z danych kwartalnych dla Polski (za lata 1999-2012) analizujemy trzy warianty reguł: adaptacyjną, bieżącą i antycypacyjną. Następnie ocenimy siłę i dynamikę wpływu inflacji i luki produkcyjnej na krótkookresową stopę procentową, mierzącą restrykcyjność polityki pieniężnej, a tym samym udzielimy odpowiedzi na pierwsze pytanie badawcze i pierwsze trzy hipotezy.

Ostatni rozdział zawiera analizę skutków zacieśnienia polityki pieniężnej w gospodarce Polski, w kontekście stosowanej reguły polityki pieniężnej. Rozpoczyna go ogólna prezentacja założeń leżących u podstaw nowokeynesistowskich modeli typu DSGE, a następnie prezentacja założeń proponowanego modelu. Równania opisujące wielkości agregatowe, wyprowadzone z założeń o optymalizacji gospodarstw domowych i przedsiębiorstw, podlegają estymacji uogólnioną metodą momentów na podstawie danych kwartalnych dla Polski (za lata 1997-2012). Do oszacowanych równań, tj. hybrydowej krzywej IS i hybrydowej krzywej Phillipsa dołączamy kolejno każdy z trzech wariantów reguły stopy procentowej. Na podstawie odpowiedzi na impuls, wyznaczonych na bazie modeli z różnymi wariantami reguły, analizujemy skutki oczekiwanego i nieoczekiwanego zacieśnienia polityki pieniężnej. Następnie symulacje te powtarzamy przy założeniu, że z ustalonym prawdopodobieństwem następują zmiany reżimów - od reguły adaptacyjnej, poprzez bieżącą, aż do antycypacyjnej. Analiza wyników symulacji pozwoli nam odpowiedzieć na drugie pytanie badawcze oraz zweryfikować hipotezę $\mathrm{H} 4$.

Dla zachowania przejrzystości wywodu, mniej istotne kwestie „techniczne” (np. szczegóły wyprowadzeń) oraz wyniki dodatkowych analiz zamieściliśmy w załącznikach.

Czuję się w obowiązku wspomnieć, że w rozdziałach 2-4 nawiązuję do moich wcześniejszych publikacji oraz że przedstawione tam wyniki badań były finansowane ze środków na naukę uzyskanych w ramach projektów badawczych realizowanych na Uniwersytecie Łódzkim.

Rozdział 2 bazuje w znacznej mierze na moim opracowaniu opublikowanym w roku 2008 w czasopiśmie „Gospodarka Narodowa” (finansowane w ramach projektu badawczego MNiSW pt. Polityka fiskalna i monetarna w okresie akcesji do strefy euro - scenariusze i wyzwania).

Wielowariantowe szacunki reguły Taylora opublikowałem w 2011 roku w czasopiśmie „Oeconomia Copernicana” (finansowane w ramach projektu badawczego MNiSW pt. Ocena skutków wprowadzenia euro w Polsce na podstawie 
dynamicznych stochastycznych modeli równowagi ogólnej). Przedstawione tam postacie reguł różniły się od tych, które prezentowane są w rozdziale 3 (brak reguły adaptacyjnej, a reguła bieżąca i adaptacyjna nie uwzględniały przyrostów inflacji i luki produkcyjnej), zaś największa zbieżność występuje w estymacjach wariantu data-rich.

Pierwsze analizy reakcji gospodarki na oczekiwany i nieoczekiwany szok polityki pieniężnej ukazały się w 2011 roku w czasopiśmie „Ekonomista” (finansowane w ramach projektu badawczego MNiSW pt. Ocena skutków wprowadzenia euro $w$ Polsce na podstawie dynamicznych stochastycznych modeli równowagi ogólnej). W artykule ograniczyłem się jednak do reguł o kalibrowanych parametrach, zaś w książce prezentuję wyniki z regułami estymowanymi. Natomiast model DSGE wykorzystywany w rozdziale 4 ma niektóre elementy zbliżone do modelu, który szacowałem wspólnie z G. Szafrańskim, a wyniki te opublikowaliśmy w czasopiśmie „Bank i Kredyt” w 2012 roku (badanie to było finansowane w ramach projektu NCN pt. Modelowanie i prognozowanie inflacji w Polsce przy pomocy modeli z endogeniczna częstotliwościa zmiany cen; mój wkład obejmował analizy za pomocą uogólnionej metody momentów - badania te są kontynuowane w pracy, podczas gdy G. Szafrański stosował metody bayesowskie - tej części artykułu nie wykorzystuję w książce).

W stosunku do przywołanych wyżej prac, w niniejszej książce poszerzono opis i uwzględniono najnowsze publikacje związane z poruszanymi zagadnieniami. Wszystkie estymacje przeprowadzono na wydłużonej próbie (kończącej się na III kw. 2012).

Dodam również, że wszystkie treści zawarte w tej książce wyrażają mój osobisty pogląd, a nie stanowią oficjalnej opinii NBP, którego jestem obecnie pracownikiem. 


\section{PODZIĘKOWANIA}

Dziękuję przede wszystkim Profesorowi Jackowi Sztaudyngerowi za pomoc w stworzeniu warsztatu naukowego, zachętę i mobilizację do pracy, a także liczne dyskusje naukowe oraz krytyczne przeanalizowanie pierwszej wersji maszynopisu. Podkreślę, że tak szeroko rozumianego wsparcia Profesor udzielał mi nie tylko jako promotor pracy doktorskiej, a później kierownik katedry, ale także w latach 2008-2012 - kiedy formalnie nie był moim przełożonym.

Wiele komentarzy i uwag zostało zgłoszone podczas seminariów i nieformalnych spotkań przez pracowników i współpracowników: Katedry Ekonometrii, Katedry Funkcjonowania Gospodarki, Katedry Makroekonomii i Katedry Modeli i Prognoz Ekonometrycznych UŁ, jak również Instytutu Ekonomicznego NBP oraz uwag zgłaszanych przez uczestników konferencji naukowych. Pozwoliło to już wtedy poszerzyć zakres badań i zastosować dodatkowe metody badawcze i zapewne poprawić niektóre błędy. W tym miejscu ponownie wszystkim dziękuję.

Za wnikliwe przeczytanie obszernych fragmentów maszynopisu i zgłoszenie konstruktywnych uwag szczególnie dziękuję: Wirginii Doryń, Mariuszowi Górajskiemu, Zbigniewowi Kuchcie, Agnieszce Leszczyńskiej oraz Szymonowi Wójcikowi.

Serdecznie dziękuję także Michałowi Brzozie-Brzezinie - nie tylko za podjęcie się roli recenzenta wydawniczego i wysiłek włożony w sporządzenie recenzji, ale przede wszystkim za mobilizację do wykonania dodatkowych obliczeń. Dzięki Jego uwagom zawartym w recenzji poszerzyłem analizy m.in. o porównanie reguł opierając się na funkcji straty banku centralnego, a także postanowiłem opisać scenariusz ,przełączania reguł”.

Oczywiście wszystkie ewentualne błędy obciążają wyłącznie mnie.

Osobne podziękowania należą się moim bliskim, którzy okazali dużo wyrozumiałości i cierpliwie wspierali mnie w trakcie powstawania tej książki. 


\section{WYBRANE KATEGORIE I METODY OPISU POLITYKI PIENIĘŻNEJ}

\section{Niespójność polityki pieniężnej w czasie}

Począwszy od końca lat siedemdziesiątych XX wieku toczy się dyskusja nad stosowaniem reguł w polityce gospodarczej, często określana w literaturze mianem „reguły kontra uznaniowość” (rules versus discrection). Od tego czasu główne ramy analityczne tej dyskusji wyznacza model dynamicznej niespójności polityki pieniężnej. Model tej klasy po raz pierwszy sformułowali Kydland i Prescott (1977)1, a kilka lat później - Barro i Gordon (1983) (zob. opis w Załącznikach 1.1 i 1.2). W modelach tych dyskrecjonalna (uznaniowa) polityka pieniężna przejawia tendencję do nadmiernej ekspansywności w celu poprawy koniunktury gospodarczej. W przypadku, gdy bank centralny kieruje się inną funkcją celu niż pozostałe podmioty, współzależność polityki pieniężnej i zachowań innych podmiotów można także przedstawić jako swego rodzaju „grę”. Rezultatem tych interakcji jest sytuacja, w której podmioty gospodarcze w pełni antycypują ,pokusę ekspansji” banku centralnego, wskutek czego poprawa koniunktury nie następuje. Wzrastają jednak oczekiwania inflacyjne, co wprost prowadzi do wyższej inflacji. Takie rozwiązanie jest spójne w czasie, choć generuje „skrzywienie inflacyjne" (inflation bias), co czyni je społecznie nieefektywnym ze względu na znaczne negatywne skutki wysokiej inflacji ${ }^{2}$. Stokey (2003, s. 9) zauważa, że korzyści ze stosowania reguł są przede wszystkim wynikiem dwu elementów modelu: wpływu oczekiwań co do przyszłej polityki gospodarczej na bieżące decyzje podmiotów oraz negatywnych „efektów zewnętrznych” jakie powoduje polityka gospodarcza.

W celu wyeliminowania lub zmniejszenia opisanego wyżej „skrzywienia inflacyjnego" zaproponowano kilka rozwiązań (por. też: Gärtner, 2000; Blinder, 2001, s. 67 i n.; Walsh, 2010, s. 283 i n.):

a) uwzględnienie w modelu reputacji banku centralnego - w takiej sytuacji gra staje się powtarzalna, a w przypadku nieoczekiwanej ekspansji monetarnej,

${ }^{1}$ Autorzy ci w roku 2004, m.in. za prace nad modelem dynamicznej niespójności w czasie, zostali uhonorowani nagrodą Banku Szwecji imienia Alfreda Nobla, www.nobelprize.org.

${ }^{2}$ Skutki te opisują np.: Wojtyna (1996), Temple (2000), Kokoszczyński (2004, s. 110-122), Sztaudynger (2005, s. 40-48) lub Ciżkowicz, Hołda i Rzońca (2010). 
władze monetarne są ,karane” w następnym okresie ze względu na wzrost oczekiwań inflacyjnych - propozycja Barro i Gordona;

b) konserwatywny bankier centralny - powierzenie sprawowania polityki pieniężnej decydentowi wykazującemu znaczną awersję do inflacji (w szczególności większą niż ogół społeczeństwa) - zaproponowane przez Rogoffa;

c) kontrakty antyinflacyjne - powiązanie użyteczności decydenta ze skutecznością prowadzonej przez niego polityki, np. poprzez uzależnienie jego wynagrodzenia od stopnia realizacji celu inflacyjnego bądź automatyczne zdymisjonowanie go w sytuacji, gdy inflacja przekroczy pewną wartość krytyczną ${ }^{3}$ - propozycja Perssona i Tabelliniego oraz niezależnie Walsha;

d) niezależność banku centralnego - zapewnienie ram instytucjonalnych umożliwiających realizację „twardej” polityki pieniężnej, np. poprzez zapewnienie niezależności banku centralnego ${ }^{4}$, w szczególności w zakresie sposobu ustalania i realizacji celów polityki pieniężnej oraz w zakresie powoływania i odwoływania członków ciał decyzyjnych - argument wysunięty po raz pierwszy przez Alesinę;

e) reguły polityki pieniężnej - rozumiane jako wiarygodne zobowiązanie banku centralnego do prowadzenia polityki antyinflacyjnej, ograniczające swobodę decyzji na rzecz rozwiązań antyinflacyjnych;

f) wpływ szeroko rozumianej polityki gospodarczej na strukturalne parametry danej gospodarki, w szczególności na wrażliwość inflacji na zmianę produkcji w krzywej Phillipsa ${ }^{5}$ (zob. Hardouvelis, 1992).

Oczywiście propozycje te w znacznej mierze są ze sobą powiązane. Przykładowo kontrakty antyinflacyjne są niczym innym jak pośrednim sposobem na włączenie inflacji do funkcji użyteczności decydenta, a zatem nie są potrzebne gdy decydent już posiada silną awersję do inflacji. Z kolei, gdy bank centralny nie jest niezależny, decydent nie może skutecznie realizować swoich celów - a zatem tracą znaczenie rozwiązania w postaci konserwatywnego bankiera centralnego czy kontraktów antyinflacyjnych. Brak niezależności utrudnia również budowania reputacji. Wydaje się, że najtrudniejsze do zastosowania jest ostanie wymienione rozwiązanie, polegające na zmianie „nachylenia” krzywej Phillipsa. Wymaga to bowiem np. spopularyzowania lub narzucenia rozwiązań instytucjonalno-prawnych służących zmianie stopnia sztywności cen.

W dalszej części książki skoncentrujemy się na regułach polityki pieniężnej, które szerzej scharakteryzujemy w kolejnym podrozdziale.

\footnotetext{
${ }^{3}$ Problem ten można analizować w kategoriach modelu mocodawca-pełnomocnik (principal-
} agent). W literaturze polskiej to podejście omawia Wojtyna (2004b).

${ }^{4} \mathrm{~W}$ literaturze polskiej zagadnienie to szeroko omawia Kokoszczyński (2004, rozdz. 6).

${ }^{5}$ Wrażliwość tę wyraża parametr $\alpha$ we wzorze (Z2-2) (zob. Załącznik 1.2). 


\section{Reguły polityki pieniężnej}

Debata nad stosowaniem reguł polityki gospodarczej (rozumianych szeroko) toczy się od wielu lat, sięgając znacznie wcześniej niż przedstawione w poprzedniej części modele dynamicznej niespójności w czasie ${ }^{6}$. McCallum (1999 s. 1485) wskazuje, że pierwsze analizy reguł polityki pieniężnej pochodzą jeszcze z XIX wieku. Ważnym głosem na rzecz stosowania reguł w polityce pieniężnej była propozycja Simonsa (1936, cyt. za: Barbaroux, 2009, s. 3), który zalecał przyjęcie reguły w celu zapewnienia ,stałego poziomu pewnego wybranego indeksu cen [tj. stabilności cen - przyp. P.B.]". Istotny wkład na rzecz stosowania reguł wnieśli przedstawiciele monetaryzmu, zwłaszcza Milton Friedman (zob. np. Snowdon, Vane, Wynarczyk, 1998, s. 173 i n.; Blinder, 2001, s. 61 i n.). Autor ten podkreślał, że wobec długich i zmiennych w czasie opóźnień towarzyszących wpływowi instrumentów na cele polityki gospodarczej, aktywna polityka stabilizacyjna może przynieść przeciwny skutek, tj. zwiększenie amplitudy wahań koniunktury. Innym tradycyjnym argumentem na rzecz stosowania reguł były teorie związane tzw. nurtem ekonomii politycznej (np. hipoteza politycznego cyklu koniunkturalnego). Wydaje się, że od czasu powszechnego zapewnienia niezależności banku centralnego, ostatni z wymienionych argumentów w większym stopniu dotyczy reguł polityki fiskalnej (zob. Mackiewicz, 2006b, s. 20; Mackiewicz, 2010a, s. 47-52).

Choć od czasu pracy Kydlanda i Prescotta większość ekonomistów opowiada się na rzecz rozwiązań o charakterze reguł’ można znaleźć argumenty uzasadniające uznaniowość (zwłaszcza organiczoną). Podkreśla się na przykład, że polityka oparta na sztywnych regułach nie jest $\mathrm{w}$ stanie poradzić sobie $\mathrm{z}$ dużymi szokami, których nie jesteśmy w stanie przewidzieć w momencie projektowania reguły (zob. np. Mankiw, Taylor, 2009, s. 455) czy zdarzeniami na tyle mało prawdopodobnymi, że celowo pomija się je w analizach (Kohn, 2004, cyt. za Bussière, Fratzscher, 2008). W ostatnim przypadku problem szczególnie dotyczy takich zdarzeń, które jeśli już wystąpią, wówczas wywierają bardzo duży wpływ na gospodarkę - tzw. high impact low probability events ${ }^{8}$. Jak się okazuje, uwzględnienie w modelu asymetrycznej informacji zmienia wnioski płynące $\mathrm{z}$ analizy modelu niespójności w czasie. W przypadku, gdy bank centralny dysponuje dodatkową, niedostępną publicznie informacją na temat gospodarki i na jej podstawie formułuje własną ocenę bieżącego stanu gospodarki i prognozy,

${ }^{6} \mathrm{~W}$ literaturze polskojęzycznej syntetyczne omówienie tej dyskusji np.: Kokoszczyński (2004, s. 61 i nast.) oraz Landreth i Colander (2005, s. 158-159).

${ }^{7}$ Snowdon, Vane i Wynarczyk (1998, s. 436, tab. 9.1) wskazują, że na siedem rozważanych szkół w makroekonomii: cztery szkoły jednoznacznie opowiadają się za regułami, w jednej brak jest wyraźnej zgody, a dwie faworyzują decyzje uznaniowe.

${ }^{8}$ Doskonałą analogią jest kryzys finansowy z $2008 \mathrm{r}$. Zanim ujawniły się jego skutki, niewielu ekonomistów dostrzegało to zagrożenie i w konsekwencji pomijała je także polityka pieniężna. 
wówczas pozostałe podmioty gospodarcze nie są w stanie precyzyjnie ocenić czy prowadzona polityka jest spójna w czasie (Canzonieri, 1985). W takiej sytuacji trudno jest ocenić ,jakość" polityki pieniężnej (w sensie spójności w czasie), co w pewnym stopniu podwyższa oczekiwania inflacyjne. W takim przypadku najlepszym sposobem prowadzenia polityki pieniężnej jest częściowe pozostawienie uznaniowości. Ze względu na cel pracy, jakim jest przede wszystkim analiza pozytywna (a nie normatywna), w tym miejscu kończymy dyskusję na temat optymalnego kształtu reguł polityki pieniężnej czy stopnia elastyczności reguły9.

Do pewnego stopnia na rzecz uznaniowości świadczy także fakt, że większość propozycji zmniejszenia skrzywienia inflacyjnego (zaprezentowanych w poprzednim podrozdziale) nie sprawdziło się w praktyce bądź są one bardzo trudne do wprowadzenia (szerzej: Blinder, 2001, s. 61 i n.).

W dyskusji „reguły czy uznaniowość” podkreśla się również, że reguły są także mechanizmem, który chroni przed szeroko rozumianą „niedoskonałością decydentów"10 (Stokey, 2003, s. 11). Co więcej, zdaniem Stokey, największe porażki polityki gospodarczej nie wynikały jedynie z niespójności tej polityki w czasie, ale także z niekompetencji polityków bądź nacisku wąskich grup interesu.

Reguły polityki pieniężnej, którym poświęcono niniejszą pracę, można podzielić na dwie główne kategorie - odnoszące się do celów (targeting rule) bądź do instrumentów (instrument rule) (por. np. Svensson, 2002; Wojtyna, 2004a, s. 144-145; Musielak-Linkowska, 2008, s. 40).

Do pierwszej z tych grup zaliczyć możemy niemal wszystkie strategie polityki pieniężnej, m.in. ${ }^{11}$ :

- kontrolę kursu walutowego,

- kontrolę nominalnego PKB,

- strategię bezpośredniego celu inflacyjnego,

- kontrolę poziomu cen.

Do reguł celów zalicza się także propozycja Friedmana (1969), zawierająca postulat stałego tempa wzrostu podaży pieniądza. W klasyfikacji Cottarelliego i Gianniniego, obejmującej dziewięć różnych systemów pieniężnych, aż w siedmiu systemach można wskazać na dużą rolę reguł (por. Wojtyna, 2004a, s. 21-22).

Reguły celów i reguły instrumentów są ze sobą ściśle związane, właściwa reguła instrumentów umożliwia bowiem skuteczne wypełnienie reguł celów

${ }^{9}$ Problem ,ile reguł a ile uznaniowości” analizowali m.in.: Lohmann (1992) oraz Athey, Atkeson i Kehoe (2005).

${ }^{10}$ Zauważmy, że w modelu Kydlanda i Prescotta decydenci polityki gospodarczej posiadają doskonałą informację, maksymalizują funkcję celu zgodną z preferencjami całego społeczeństwa itp.

${ }^{11}$ Należy zaznaczyć, że niektórzy autorzy nie klasyfikują strategii bezpośredniego celu inflacyjnego jako reguły. Przykładowo, Bernanke i Mishkin (1997) wskazują że jest to raczej podejście (framework) niż sztywna reguła. 
(strategii). Rozróżnienie utrudnia jednak fakt, że historycznie zmianie ulegały poglądy na temat celów polityki pieniężnej. Na przykład w latach 60. XX wieku stopa procentowa była rozważana jako możliwy cel pośredni, a obecnie jest ona traktowana wyłącznie jako instrument polityki pieniężnej (por. Szpunar, 2000, rozdz. 3.4). Innym przykładem tego typu wątpliwości może być reguła McCalluma (1988, 2000), opisująca tempo wzrostu bazy monetarnej w zależności od odchylenia tempa wzrostu nominalnego PKB od wartości pożądanej (równej sumie docelowej wartości inflacji i tempa wzrostu potencjalnego PKB) ${ }^{12}$.

Dotychczasowe rozważania dotyczyły przede wszystkim reguł celów, obecnie natomiast skoncentrujemy się na regułach instrumentów, które Taylor (1999, s. 319) definiuje jako ,szczegółowy, wyrażony przy pomocy równania, liczby lub rysunku, opis w jaki sposób instrumenty polityki [...], reagują na zmienne opisujące stan gospodarki".

Rozważając różnice pomiędzy regułami celów a regułami instrumentów, warto wspomnieć, że reguła instrumentów dopuszcza zwykle pewną dozę elastyczności ${ }^{13}$, zaś reguła celów w większości przypadków stanowi silniejsze zobowiązanie. Wydaje się również, że reguła celów - o ile jest faktycznie realizowana - opisuje politykę pieniężną w długim okresie, a reguła instrumentów opisuje „procedury” działania banku centralnego, które mogą dotyczyć zarówno długiego jak i krótkiego okresu.

Kolejną różnicą pomiędzy regułami celów i instrumentów jest komunikacja reguły przez władze monetarne. Niemal wszystkie banki centralne oficjalnie deklarują przywiązanie do reguły celów ${ }^{14}$, dzięki czemu zwiększa się wiarygodność polityki pieniężnej i tym samym stabilizuje na niskim poziomie oczekiwania inflacyjne. Znacznie rzadziej władze monetarne przyznają się do stosowania reguł instrumentów. Taka niechęć może wynikać z trudności w komunikacji, na ile decyzje są kształtowane przez prostą, „mechaniczną” regułę, a na ile biorą pod uwagę szersze spektrum zmiennych określających obecny i przyszły stan gospodarki (co zawsze w pewnym stopniu ma charakter uznaniowy). Stąd też można przyjąć, iż reguły instrumentów polityki pieniężnej mają w dużej mierze charakter modelowego opisu reakcji banku centralnego na zmiany zachodzące w gospodarce - w odróżnieniu od np. analogicznych

${ }^{12}$ Na marginesie warto dodać, że różne reguły często dają zbliżone wyniki. Np. Razzak (2003) porównuje regułę stopy procentowej Taylora oraz regułę wzrostu podaży pieniądza McCalluma. Wskazuje on, że przy założeniu, że szybkość cyrkulacji pieniądza jest funkcją stopy procentowej, obie reguły są niemal identyczne. Wnioski te potwierdzono następnie za pomocą analiz empirycznych.

${ }^{13}$ Wydaje się, że większość banków centralnych tłumaczy przyczyny niezrealizowania celu inflacyjnego bardziej szczegółowo niż decyzje dotyczące instrumentów polityki pieniężnej.

${ }^{14}$ Według Kokoszczyńskiego (2004, s. 227), w Polsce o strategii polityki pieniężnej możemy mówić od 1991 r. W 1990 polityka pieniężna „nie była autonomiczną częścią polityki gospodarczej, lecz fragmentem szerszego programu stabilizacyjnego" (tamże, s. 226), którego celem była jednocześnie stabilizacja gospodarki jak i realizowanie zmian systemowych. 
reguł dla polityki fiskalnej, które są dużo mniej elastyczne (szczególnie gdy wynikają z przepisów prawa).

Na koniec wspomnijmy o barwnej analogii dotyczącą żeglarstwa, której Taylor (2000, cyt. za: Wojtyna, 2004c, s. 28) użył do przedstawienia różnic pomiędzy regułami celów a instrumentów. W tej analogii reguła celów wskazuje na port przeznaczenia, a reguła instrumentów - zasady sterowania jachtem, które pomagają osiągnąć ten cel.

Jak już wspomniano, współcześnie niemal wszystkie banki centralne ${ }^{15}$ stosują w charakterze podstawowego instrumentu kontrolę krótkookresowej stopy procentowej (zagadnienie to szerzej opisujemy w rozdz. 2). Zapewne to sprawiło, że współczesna dyskusja toczy się głównie wokół reguł stóp procentowych.

Pierwszą regułę stopy procentowej wprowadził Wicksell już na przełomie XIX i XX wieku (zob. Woodford, 2003, s. 7-39; Barbaroux, 2009, s. 3). Reguła ta odzwierciedlała postulat dodatniej zależności pomiędzy stopą procentową a poziomem cen. Wicksell twierdził, że gdy ceny rosną, należy podwyższyć stopy procentowe (i na odwrót) i pozostawić je na nowo ustalonym poziomie aż do czasu, gdy ceny się ustabilizują (Barbaroux, 2009, s. 35). Wprawdzie Wicksell nie zapisał swojej reguły w postaci równania, jednak z tego opisu wyłania się obraz polityki pieniężnej której celem jest raczej zerowa inflacja niż stały poziom cen (tzn. po wzroście cen bank centralny nie stara się przywrócić poprzedniego poziomu cen).

W pracy rozważać będziemy regułę Taylora, która jest najbardziej popularną regułą stopy procentowej - w rozdziale 2 przedstawiamy przegląd dotychczasowych badań nad modyfikacjami reguły Taylora, zaś w rozdziale 3 przedstawiamy wyniki empirycznej weryfikacji tych reguł dla Polski.

\section{Pomiar inflacji}

Inflację powszechnie definiuje się jako ,proces wzrostu ogólnego poziomu cen", zaś miarą natężenia procesów inflacyjnych jest stopa inflacji, czyli tempo wzrostu ogólnego (przeciętnego) poziomu cen.

Trudności związane z pomiarem inflacji wynikają przede wszystkim z niejednoznaczności pojęcia „ogólny poziomu cen”. Lebow i Rudd (2008) wyróżniają tu trzy najważniejsze problemy:

1) w jaki sposób agregować ceny pojedynczych dóbr,

2) jaki zakres dóbr powinien obejmować indeks,

3) czy ceny poszczególnych dóbr są właściwie mierzone.

${ }^{15}$ Chodzi oczywiście o banki centralne, które utrzymują reżim płynnego kursu walutowego - a więc w myśl koncepcji trójkąta niemożliwości (zob. np. Małecki, Sławiński, 2011, s. 195-197) mają możliwość prowadzenia autonomicznej polityki pieniężnej. 
W celu pomiaru ogólnego poziomu cen konstruuje się różne agregatowe indeksy (wskaźniki) cen. Omówienie tego zagadnienia rozpoczniemy od zdefiniowania indeksu cen.

Dla indeksu cen wyrażonego za pomocą funkcji:

$$
I C\left(\mathbf{p}_{\mathrm{t}}, \mathbf{p}_{0}, \mathbf{x}_{\mathrm{t}}, \mathbf{x}_{0}\right) \rightarrow R^{+}
$$

gdzie:

$\mathbf{p}_{\mathbf{t}}$ i $\mathbf{p}_{\mathbf{0}}$ - wektory cen, w okresie badanym (subskrypt $t$ ) i bazowym (subskrypt 0 ),

$\mathbf{x}_{\mathbf{t}}$ i $\mathbf{x}_{\mathbf{0}}$ - wektory ilości nabywanych dóbr, w okresie badanym i bazowym.

Dla dowolnych ${ }^{16} \mathbf{p}_{\mathbf{t}}, \mathbf{p}_{\mathbf{0}}$ oraz $\mathbf{p}_{\mathbf{t}}>\mathbf{p}_{\mathbf{n}}$ zachodzić powinny następujące zależności (Kokoszczyński, 2004, s. 133) ${ }^{17}$ :

- warunek jednoznaczności (normalizacji): jeśli $\mathbf{p}_{\mathbf{t}}=\mathbf{p}_{\mathbf{0}}$ wówczas funkcja IC osiąga wartość 1 ,

- warunek proporcjonalności (homogeniczności): jeśli $\mathbf{p}_{\mathbf{t}}=k \mathbf{p}_{\mathbf{0}}$ wówczas funkcja $I C$ osiąga wartość $k$,

- warunek odwracalności $\mathrm{w}$ czasie: $I C\left(\mathbf{p}_{\mathbf{0}}, \mathbf{p}_{\mathbf{t}}, \mathbf{x}_{\mathbf{t}}, \mathbf{x}_{\mathbf{o}}\right)=\frac{1}{I C\left(\mathbf{p}_{0}, \mathbf{p}_{\mathbf{t}}, \mathbf{x}_{\mathrm{t}}, \mathbf{x}_{\mathbf{0}}\right)}$,

- warunek monotoniczności: $I C\left(\mathbf{p}_{0}, \mathbf{p}_{\mathrm{t}}, \mathbf{x}_{\mathrm{t}}, \mathbf{x}_{\mathbf{0}}\right) \geq \operatorname{IC}\left(\mathbf{p}_{0}, \mathbf{p}_{\mathrm{t}}, \mathbf{x}_{\mathrm{t}}, \mathbf{x}_{\mathbf{0}}\right)$.

Biorąc pod uwagę najbardziej ogólne kryterium podziału indeksów cen opartych na teorii kosztów utrzymania, tzn. sposób obliczania tych kosztów, wyróżnić możemy dwie grupy indeksów (Woźniak, 2002, s. 29-29; The New..., 2003, s. 13).

Pierwszy rodzaj indeksów służy do porównania minimalnych wydatków potrzebnych na zakup koszyków dóbr przynoszących tę samą użyteczność. Ten sposób liczenia ogólnego poziomu możemy przedstawić za pomocą następującego zapisu:

przy warunku:

$$
I C^{u}\left(\mathbf{p}_{\mathbf{0}}, \mathbf{p}_{\mathbf{t}}, \mathbf{x}_{\mathbf{t}}, \mathbf{x}_{\mathbf{0}}\right)=\frac{\min _{x_{t}}\left(\mathbf{p}_{\mathbf{t}}^{\mathbf{T}} \mathbf{x}_{\mathbf{t}}\right)}{\min _{x_{t}}\left(\mathbf{p}_{\mathbf{0}}^{\mathbf{T}} \mathbf{x}_{\mathbf{0}}\right)}
$$

$$
U\left(\mathbf{x}_{\mathrm{t}}\right)=U\left(\mathbf{x}_{\mathbf{0}}\right)
$$

gdzie: $U$ - oznacza funkcję użyteczności reprezentatywnego gospodarstwa domowego.

${ }^{16}$ Wektory te wyrażają ceny i ilości, zatem należy tu rozpatrywać jedynie wektory (kolumnowe) o nieujemnych składowych.

${ }^{17}$ Opracowanie, na które się powołujemy podaje tylko wzory, nie nazywając poszczególnych warunków. Dlatego też nazwy warunków 1-3 zaczerpnięto z pracy Welfego (1966, s. 40-43). 
Idea tego sposobu pomiaru ogólnego poziomu cen bazuje na teorii wyboru konsumenta. Konsument dokonuje wyboru struktury konsumpcji w celu maksymalizacji użyteczności przy danym ograniczeniu budżetowym. Zastosowanie tej koncepcji do pomiaru indeksów cen wymaga określenia jak rozumiemy porównywalne koszyki. Badana jest więc relacja wartości zakupionych porównywalnych koszyków dóbr (przy czym ich strukturę w dalszym ciągu wybiera konsument, kierując się maksymalizacją użyteczności). Ich porównywalność przejawia się tym, iż przynoszą one jednakową użyteczność konsumentowi.

Z uwagi na brak możliwości obserwacji i pomiaru preferencji konsumentów, brak jest danych odnośnie do tak liczonej inflacji. Ta interesująca koncepcja jest jednak wykorzystywana $\mathrm{w}$ modelach teoretycznych ${ }^{18}$ oraz stanowi bazę teoretyczną do konstrukcji indeksów cen typu COLI (Cost of Living Index).

W obliczu braku możliwości empirycznego wyznaczenia indeksu cen opartego na funkcji użyteczności, w praktyce stosuje się indeksy służące do porównania kosztu nabycia określonego koszyka produktów. Konstrukcja tych indeksów oparta jest na założeniu, że koszyk jest niezmienny, tj. struktura wydatków jest jednakowa w okresie badanym i bazowym. Struktura koszyka powinna być zbliżona do struktury badanego zestawu produktów - np. w wypadku dóbr konsumpcyjnych do przeciętnej struktury konsumpcji gospodarstw domowych.

Powyższe rozważania prowadzą nas do dwu najprostszych formuł indeksów (zob. np.: Domański, 2001, s. 221; Kokoszczyński, 2004, s. 138-139).

Indeks typu Laspeyresa - przyjmuje się strukturę koszyka z okresu bazowego (0):

$$
I C^{L}\left(\mathbf{p}_{\mathrm{t}}, \mathbf{p}_{0}, \mathbf{x}_{\mathrm{t}}, \mathbf{x}_{0}\right)=\frac{\mathbf{x}_{0}^{T} \mathbf{p}_{\mathrm{t}}}{\mathbf{x}_{0}^{T} \mathbf{p}_{\mathbf{0}}}
$$

Indeks typu Paaschego - przyjmuje się strukturę koszyka z okresu badanego $(t)$ :

$$
I C^{P}\left(\mathbf{p}_{\mathrm{t}}, \mathbf{p}_{\mathbf{0}}, \mathbf{x}_{\mathrm{t}}, \mathbf{x}_{\mathbf{0}}\right)=\frac{\mathbf{x}_{\mathrm{t}}^{T} \mathbf{p}_{\mathrm{t}}}{\mathbf{x}_{\mathrm{t}}^{T} \mathbf{p}_{\mathbf{0}}}
$$

W ogólnym przypadku wartości tych indeksów dla jednakowych: $\mathbf{p}_{\mathbf{t}}, \mathbf{p}_{\mathbf{0}}$, $\mathbf{x}_{\mathbf{t}}, \mathbf{x}_{\mathbf{0}}$ różnią się od siebie. Ponadto indeksy Laspeyresa i Paaschego nie spełniają warunku odwracalności w czasie. $Z$ tego powodu zaproponowano inne sposoby agregacji cen, a w rezultacie inne formuły indeksów. Spośród wielu najciekawszymi wydają się ${ }^{19}$ :

- indeks Fishera będący średnią geometryczną z wymienionych indeksów typu Laspeyresa i Paaschego,

${ }^{18}$ Por. np. indeksy zaproponowane przez Dixita i Stiglitza (1977), wykorzystywane w modelach klasy DSGE.

${ }^{19}$ Szczegółowe formuły tych indeksów oraz omówienie innych rodzajów indeksów przedstawiają: Kokoszczyński (2004, s. 139-142) oraz Białek (2010). 
- indeks Marshalla-Edgewortha, w którym ilości nabywanych dóbr przyjmuje się na poziomie średniej arytmetycznej z okresu badanego i bazowego,

- indeks Walsha, w którym ilości nabywanych dóbr przyjmuje się na poziomie średniej geometrycznej z okresu badanego i bazowego.

Drugi problem wyróżniony przez Lebowa i Rudda (2008) dotyczył zakresu dóbr włączanych do indeksu cen.

W praktyce najszersze zastosowanie mają miary inflacji obejmujące swym zakresem pełen koszyk towarów i usług konsumpcyjnych, dla których istnieją dobrze zdefiniowane ceny ( $\mathrm{tj}$. nabywane na wolnym rynku). Taki zakres brany jest pod uwagę przy wyliczaniu indeksu cen towarów i usług konsumpcyjnych (Consumer Price Index, CPI). W Polsce (oraz w większości krajów stosujących strategię bezpośredniego celu inflacyjnego) przy pomocy tego wskaźnika wyrażony jest cel inflacyjny. Największe znaczenie CPI wynika także z tego, że gospodarstwa domowe są zainteresowane cenami dóbr konsumpcyjnych w znacznie większym stopniu niż cenami pozostałych produktów. Ponadto idea pomiaru kosztów utrzymania (COLI), leżąca u podstaw konstrukcji tych indeksów wyraźnie ogranicza zakres koszyka do dóbr konsumpcyjnych. Wreszcie - dane statystyczne o deflatorze PKB szacowane są z częstotliwością kwartalną, z opóźnieniem rzędu co najmniej 2-3 miesięcy (por. np. Woźniak, 2002, s. 10), co utrudnia wykorzystanie tego wskaźnika jako podstawy prowadzonej polityki pieniężnej.

Indeks CPI jest najczęściej używanym indeksem cen służącym do obliczania inflacji, a jego historia sięga początku XX wieku (zob. Kokoszczyński, 2004, s. 13) - po raz pierwszy ten indeks cen został opublikowany przez urząd statystyczny USA (BLS) w 1903 roku (Reinsdorf, Triplett, 2009, s. 17). W Polsce wskaźnik CPI (cen towarów i usług konsumpcyjnych) oblicza się dla ponad 1500 reprezentantów towarów i usług w ponad 200 rejonach notowań (Ceny w gospodarce narodowej ...). Agregacja pojedynczych cen przebiega następująco: na początku wylicza się wskaźniki łańcuchowe dóbr reprezentantów, liczone jako relacja średniej ceny reprezentanta w rejonie do ceny z okresu odniesienia. Następnie wskaźniki te agreguje się przestrzennie, obliczając średnią geometryczną ${ }^{20}$ ze wskaźników w poszczególnych rejonach notowań. Na ich podstawie, ponownie stosując średnią geometryczną, opracowuje się wskaźniki cen grup towarów i usług na szczeblu tzw. grup elementarnych (wyróżnia się ponad 300 takich grup). Dalsza agregacja przebiega według formuły Laspeyresa, przy czym, jak już wspominano, dane o strukturze wydatków konsumpcyjnych pochodzą z badania budżetów gospodarstw domowych z roku poprzedniego (wagi są corocznie aktualizowane).

Okazuje się jednak, że nawet ograniczając pomiar inflacji do cen dóbr konsumpcyjnych, możemy znaleźć alternatywy dla indeksu cen towarów i usług konsumpcyjnych. Najczęściej spotyka się miary inflacji bazowej oraz HICP (zharmonizowany indeks cen konsumpcyjnych, Harmonised Index of Consumer Prices).

${ }^{20} \mathrm{~W}$ tym miejscu odchodzi się od formuły Laspeyresa, co zmniejsza błąd substytucji (opisany dalej w tab. 1.1.). 
Koncepcja inflacji bazowej ma na celu obliczenie inflacji wyrażającej średnio- lub długookresowe tempo zmiany cen, tzn. z pomięciem działania krótkookresowych szoków oraz zdarzeń na które polityka pieniężna nie ma wpływu.

Definicja taka jest bardzo ogólna, stąd też inflacja bazowa nie jest bezpośrednio rejrestrowana przez urzędy statystyczne i musi być oszacowana przy pewnych dodatkowych założeniach ${ }^{21}$. Istnieje wiele metod obliczania inflacji bazowej (zob. np. Woźniak, 2002; Bermingham, 2010; Metodologia obliczania..., 2012):

a) z wyłączeniem ustalonych kategorii cen - co do których twierdzi się, że są w znacznym stopniu kształtowane przez czynniki niezależne od polityki pieniężnej (jak np. wahania cen na rynkach światowych, ceny ustalane administracyjnie lub o dużym udziale podatków i opłat);

b) średnie obcięte (tj. z wyłączeniem ustalonego odsetka cen o najwyższej i najniższej dynamice) lub średnie ważone wariancją;

c) wygładzanie mechanicznie za pomocą filtrów statystycznych;

d) otrzymywane na podstawie modeli ekonometrycznych.

W Polsce miary inflacji bazowej oblicza i publikuje Narodowy Bank Polski, przy czym od 2009 roku publikowane są cztery indeksy ${ }^{22}$ :

a) inflacja po wyłączeniu cen administrowanych,

b) inflacja po wyłączeniu cen najbardziej zmiennych,

c) inflacja po wyłączeniu cen żywności i energii,

d) $15 \%$ średnia obcięta.

Z kolei dane o wskaźniku HICP dla gospodarki Polski są dostępne od $1996 \mathrm{roku}^{23}$. Jednocześnie NBP wykorzystuje ten wskaźnik jedynie pomocniczo (podobnie jak inflację bazową). Oprócz danych dla pojedynczych krajów, publikuje się także agregat dla wszystkich krajów wchodzących w skład Unii Gospodarczej i Walutowej (MUICP, Monetary Union Index of Consumer Prices). Za pomocą tego ostatniego definiowany jest cel strategiczny (finalny) Europejskiego Banku Centralnego, natomiast dane dla pojedynczych krajów służą m.in. ocenie spełniania inflacyjnego kryterium konwergencji z Maastricht. Tak więc wskaźnik ten ma większe znaczenie dla krajów należących lub ubiegających się o członkostwo w strefie euro.

${ }^{21}$ Bermingham (2010) wskazuje na analogię do takich mierników ekonomicznych jak produkcja potencjalna czy NAIRU (Non Accelerating Inflation Rate of Unemployment). Analogia ta jest widoczna jeszcze wyraźniej kiedy porównamy metody szacowania inflacji bazowej (przedstawione w niniejszym podrozdziale) i produkcji potencjalnej (co opiszemy w kolejnym podrozdziale).

${ }^{22}$ Szczegółowy opis sposobu wyliczania tych szeregów prezentuje: Metodologia obliczania... (2012).

${ }^{23}$ Jak podaje Sztaudynger (2002, s. 262) jedyną różnicą pomiędzy polskim wskaźnikiem CPI a HICP jest inny system wag. Twierdził on, że różnica w stopie inflacji mierzonej za pomocą HICP oraz CPI nie przekracza 0,1 p. proc. miesięcznie (co w ujęciu rocznym dałoby ok. 1,2 p. proc.). Późniejsze różnice nie przekraczały tego progu. Największą różnicę tych wskaźników odnotowano w maju $2011 \mathrm{r}$. - sięgnęła ona 0,7 p. proc. (w ujęciu rocznym), choć różnica ta w znacznej mierze wynikała ze zmiany metodyki liczenia inflacji CPI. 
Pomiar każdej kategorii ekonomicznej obarczony jest błędem. Dotyczy to również inflacji. W tym wypadku jednak znaczna część błędu pomiaru wynika z samej konstrukcji miar inflacji - zob. tab. 1.1.

Tabela 1.1. Najważniejsze źródła błędów pomiaru inflacji

\begin{tabular}{|c|c|}
\hline Źródło błędu & Opis \\
\hline Substytucja dóbr & $\begin{array}{l}\text { Konstrukcja indeksu zakłada stałą strukturę koszyka, podczas gdy w rze- } \\
\text { czywistości ilość konsumowanych dóbr zmienia się w czasie. W przypadku } \\
\text { wzrostu ceny danego dobra, gospodarstwa domowe starają się substytuować } \\
\text { je za pomocą tańszych odpowiedników*. Wobec tego wydatki na dobra, któ- } \\
\text { rych cena wzrosła w największym stopniu będą malały (w relacji do całej } \\
\text { konsumpcji). W wypadku indeksu typu Laspeyresa, poziom cen wylicza się } \\
\text { stosując wagi z okresu bazowego, a zatem udział produktów o wysokiej dy- } \\
\text { namice cen w okresie bieżącym jest zawyżony. To z kolei powoduje dodat- } \\
\text { nie obciążenie (zawyżenie) stopy inflacji. W przypadku indeksu Paaschego } \\
\text { kierunek obciążenia będzie przeciwny. Obciążenia z tego tytułu nie będą } \\
\text { wykazywały np. indeksy Fishera oraz Törnqvista. }\end{array}$ \\
\hline Zmiana jakości & $\begin{array}{l}\text { Notowania cen poszczególnych dóbr-reprezentantów powinny dotyczyć } \\
\text { dokładnie tych samych produktów. W rzeczywistości jednak wiele produk- } \\
\text { tów (np. wskutek postępu technicznego) poprawia swoją jakość (dotyczy to } \\
\text { zwłaszcza towarów takich jak samochody czy elektronika), czego zwykle } \\
\text { nie jest stanie notować statystyka publiczna. Brak pełnego uwzględnienia } \\
\text { zmian jakości powoduje, że uwzględnia się ceny wyższe niż byłyby w przy- } \\
\text { padku braku zmiany jakości, a co za tym inflacja jest zawyżona. }\end{array}$ \\
\hline $\begin{array}{l}\text { Wprowadzenie } \\
\text { nowych dóbr }\end{array}$ & $\begin{array}{l}\text { Dla dóbr, które zostały po raz pierwszy wprowadzone na rynek nie istnie- } \\
\text { je cena z okresu bazowego. Teoria wskazuje, że w takim wypadku powin- } \\
\text { no się przyjąć sztuczną cenę, przy której popyt na dane dobro byłby zerowy. } \\
\text { Jednak wyliczenie takiej ceny wymaga precyzyjnego oszacowania funkcji } \\
\text { popytu na nowe dobra, co także jest niewykonalne. Co więcej, nowe dobra } \\
\text { wchodzą w skład koszyka ze znacznym opóźnieniem**. W rezultacie indeks } \\
\text { cen jest niedoszacowany. }\end{array}$ \\
\hline $\begin{array}{l}\text { Nieprecyzyjnie } \\
\text { oszacowane } \\
\text { wagi }\end{array}$ & $\begin{array}{l}\text { Wagi do indeksu obliczane są na podstawie badań ankietowych (w Polsce: } \\
\text { badań budżetów gospodarstw domowych). Wyniki tych badań są obarczone } \\
\text { stosunkowo dużym błędem, przy czym nie można z góry określić, czy będzie } \\
\text { to powodowało przeszacowanie, czy też niedoszacowanie stopy inflacji. }\end{array}$ \\
\hline
\end{tabular}

* Dodajmy, że obciążenie to może być różnie rozumiane. Np. Lebow i Rudd (2003) rozróżniają substytucję ,pomiędzy” poszczególnymi kategoriami dóbr notowanymi przez statystykę publiczną (upper level substitution) oraz „wewnątrz” danej kategorii (lower level substitution). Substytucja może mieć również miejsce w wymiarze „przestrzennym” - tj. konsumenci zwiększą wydatki w sklepach, które relatywnie obniżyły ceny oferowanych produktów.

"* Doskonałym przykładem mogą być telefony komórkowe, które zostały wprowadzone do koszyka CPI w Polsce dopiero w 2006 r. (por. Hałka, Leszczyńska, 2011), a w Stanach Zjednoczonych - w 1999 r. (por. Hausman, 2003 oraz prace tam cytowane). W obu przypadkach daje to około 15-letnie opóźnienie, licząc od momentu pojawienia się tego dobra na danym rynku.

Źródło: opracowanie własne, na podstawie Hausman (2003); Lebow i Rudd (2003, 2008). 
Opisane powyżej błędy nie zawsze mogą być w pełni skorygowane przy konstrukcji indeksów cen konsumpcyjnych. Na przykład, błąd substytucji może zostać zminimalizowany poprzez częstą aktualizację wag indeksu, aczkolwiek w tym wypadku tracimy możliwość klarownego porównania odległych w czasie wartości indeksów (można jednak liczyć osobno tempa zmiany cen ze zmiennymi wagami, a osobno wskaźniki jednopodstawowe - tak jest w Polsce). Z kolei uwzględnienie wpływu nowych produktów i zmian jakości wymagałoby zaangażowania towaroznawców lub precyzyjnego oszacowania równań popytu na nowowprowadzane dobra. Podobnie dzieje się w przypadku zmiany jakości dóbr, aczkolwiek statystycy opracowali już kilka metod pozwalających oszacować wpływ zmiany jakości na ceny ${ }^{24}$.

W efekcie można się spodziewać, że inflacja będzie się cechować pewnym przeszacowaniem wskaźnika względem ,,prawdziwej” (idealnie mierzonej) stopy inflacji. Wyniki takie znajdują uzasadnienie na gruncie teoretycznym (np. ujemna zależność popytu od ceny) oraz są zwykle potwierdzane przez badania empiryczne dla krajów wysoko rozwiniętych ${ }^{25}$.

Dla Polski wskazuje się na przeciwny kierunek obciążenia wskaźników dynamiki cen. Znane nam wyniki trzech takich badań dla Polski stwierdzają zgodnie niedoszacowanie inflacji:

Zienkowski i Cywil (1992, s. 8) przypuszczają, iż szacunki indeksów cen w Polsce w latach 1975-1990 były „szczególnie mało dokładne”. Porównanie dynamik realnego PKB liczonych różnymi metodami prowadzi ich do wniosku, że w latach 1980-1990 wzrost cen był niedoszacowany o 8-12 p. proc. (tj. o 0,8-1,1 p. proc. rocznie, uwzględniając procent składany).

Sztaudynger (2003, s. 91-102) stwierdza, iż w Polsce w latach 1973-1989 występowało niedoszacowanie indeksu cen PPI. Błąd ten zawarty był w granicach 4-7\% oficjalnie wykazywanej inflacji, np. w latach 1980-1989 wyniósł on około 1,5 p. proc. rocznie.

Hałka i Leszczyńska (2011) analizowały obciążenie polskiego indeksu CPI w latach 2005-2009 z tytułu substytucji dóbr. Ich wyniki wskazują na brak obciążenia lub nieznaczne niedoszacowanie inflacji, które sięga maksymalnie 0,1 p. proc. rocznie.

Poza zróżnicowaniem sposobów pomiaru ogólnego poziomu cen, wyróżnić możemy różne sposoby liczenia tempa wzrostu ogólnego poziomu cen ${ }^{26}$. Pierwszy sposób to odniesienie wskaźnika cen z analizowanego okresu ze wskaźnikiem $\mathrm{z}$ analogicznym okresem roku poprzedniego (np. grudzień do grudnia ubiegłego

${ }^{24}$ Omówienie tych metod znajduje się np. w: Śmiłowska i Cynkier (2002).

${ }^{25}$ Szerzej badania te opisują np.: Baranowski (2008a, rozdz. 1.3) oraz Hałka i Leszczyńska (2011).

${ }^{26}$ Opisany niżej dylemat dotyczy jedynie inflacji liczonej dla częstotliwości większych niż rok. Dla inflacji o częstotliwości rocznej możemy natomiast wyróżnić inflację średnioroczną lub liczoną na koniec roku (tj. grudzień do grudnia). 
roku bądź IV kwartał do IV kwartału ubiegłego roku). Tak wyrażona inflacja nie podlega wahaniom sezonowym i dlatego też jest najczęściej wykorzystywana w praktyce (w szczególności w ten sposób wyrażony jest cel inflacyjny NBP - zob. Strategia ..., s. 12). Naszym zdaniem wykorzystanie takiej zmiennej w modelach ekonometrycznych powinno być ograniczone jedynie do przypadków, gdy analizujemy reakcje instytucji państwowych lub rynków finansowych. Drugim sposobem jest porównanie wskaźników z sąsiadujących okresów. Taka miara inflacji wyraża wyłącznie wzrost cen który nastąpił w trakcie danego okresu ${ }^{27}$. Stąd też wydaje się, że poza przypadkami wymienionymi powyżej, w modelach ekonometrycznych powinno się korzystać z takiej zmiennej. Jednak inflacja liczona w stosunku do poprzedniego okresu wykazuje wahania sezonowe, a zatem nie jest w pełni porównywalna w czasie. Rozwiązaniem tego problemu, w kontekście użycia tej zmiennej do modelowania ekonometrycznego, może być mechaniczne pozbawienie szeregów sezonowości (np. za pomocą metod Tramo/Seats lub Census X-12 - por. Grudkowska, Paśnicka, 2007) bądź poszerzenie specyfikacji o opis sezonowości (np. w przypadku deterministycznej sezonowości - dodanie zmiennych zerojedynkowych).

\section{Pomiar luki produkcyjnej}

W przeciwieństwie do modeli wzrostu, w analizach krótkookresowych (w tym polityki pieniężnej) przedmiotem zainteresowania są zwykle wahania produkcji pozbawione komponentu długookresowego. Stąd analizuje się lukę produkcyjną, zdefiniowaną jako procentową różnicę pomiędzy produkcją faktyczną a jej długookresowym trendem (niekiedy utożsamianym z produkcją potencjalną̨28). Główny problem leży w tym, że długookresowy komponent produkcji nie jest bezpośrednio obserwowalny.

Burns i Mitchell (1946, s. 3) wskazują dwa stylizowane fakty ułatwiające identyfikację wahań koniunkturalnych. Po pierwsze, fluktuacje cykliczne mają charakter powtarzający się, ale niekonieczne ściśle okresowy (regularny). Po drugie, zmiany stanu koniunktury następują stosunkowo powoli ${ }^{29}$ (cechują się wysokim stopniem autokorelacji - persistence).

${ }^{27}$ Zauważmy, że inflacja liczona względem analogicznego kwartału roku poprzedniego, wyraża de facto wzrost cen w danym kwartale a także w 3 poprzednich kwartałach.

${ }^{28}$ Takie rozumienie długookresowego trendu produkcji nie jest naszym zdaniem w pełni uprawnione w odniesieniu do wszystkich współczesnych modeli makroekonomicznych. Przykładowo, w modelach realnego cyklu koniunkturalnego produkcja zawsze jest równa potencjalnej, a wahania cykliczne związane są skutkiem zmian poziomu łącznej produktywności czynników produkcji.

${ }^{29} \mathrm{~W}$ przypadku danych kwartalnych typowa częstotliwość wahań koniunkturalnych wynosi od 6 do 40 kwartałów (zob. np. Dejong i Dave, 2007, s. 32). 
Powyższe wskazówki mają charakter bardzo ogólny, stąd istnieje wiele sposobów szacowania produkcji potencjalnej, a co za tym idzie - luki produkcyjnej. Tradycyjnie wymienia się metody wykorzystujące (zob. np.: Cerra, Saxena, 2000; Grzęda Latocha, 2005, s. 30 i n.,: Gradzewicz, Kolasa, 2004; Canova, 2007, rozdz. 3):

- funkcję produkcji,

- modele trendu deterministycznego,

- modele trendu w szczytach,

- modele zmiennych nieobserwowalnych,

- strukturalne modele VAR z długookresowymi restrykcjami,

- filtry statystyczne (np. Hodricka-Prescotta, Baxtera-Kinga, ChristianoFitzgeralda).

Spotyka się także mniej standardowe spojrzenia na pomiar aktywności gospodarczej.

Często zamiast luki produkcyjnej wykorzystuje się tzw. lukę bezrobocia - odchylenie stopy bezrobocia od naturalnej stopy bezrobocia, aproksymowaną na różne sposoby (zob. np. Hsing, 2005; Mark, 2009). Zgodnie z prawem Okuna, miara ta jest proporcjonalna do luki produkcyjnej.

Z kolei Gali i Gertler (1999) wskazują, że dobrą miarę aktywności gospodarczej stanowi odchylenie realnych kosztów krańcowych od równowagi. Miarę tę można, przy założeniu doskonałej konkurencji na rynku czynników produkcji, wyrazić za pomocą udziału kosztów pracy w produkcie. Jednocześnie z warunku optymalizacji gospodarstw domowych w modelu nowokeynesistowskim można zauważyć, że zachodzi proporcjonalność pomiędzy procentowym odchyleniem realnych kosztów krańcowych od równowagi a luką produkcyjną (zob. wyprowadzenie w Załączniku 4.2). W ten sposób odzwierciedleniem luki produkcyjnej jest udział kosztów pracy w produkcie (liczony jako iloraz odpowiednich kategorii nominalnych). Badanie Galego i Gertlera (1999) oraz wiele jego kontynuacji (np. Gali, Gertler i Lopez-Salido, 2005; Gwin, VanHoose, 2008) potwierdzają silny wpływ tej kategorii na inflację.

Alternatywny sposób pomiaru luki produkcyjnej wykorzystuje dane ankietowe pochodzące z tzw. testów koniunktury (Grzęda Latocha, Nerb, 2003; Grzęda Latocha, 2005), w ramach których ankietuje się przedsiębiorstwa co do aktualnego lub oczekiwanego poziomu różnych miar aktywności gospodarczych takich jak: wielkość produkcji, popytu, portfel zamówień itd. W Polsce badania takie są prowadzone od połowy 1992 roku i dotyczą jedynie niektórych sektorów gospodarki, głównie przemysłu, handlu i budownictwa; w przypadku usług GUS rozpoczął gromadzenie odpowiednich danych dopiero w 2003 roku (zob. Badanie koniunktury..., 2011).

Niezależnie od podziału wymienionego powyżej, można wyróżnić metody wyznaczania cyklu bazujące wyłącznie na jednym szeregu czasowym - mierze 
produkcji (metody jednowymiarowe) lub wykorzystujące także dodatkowe zmienne (wielowymiarowe) ${ }^{30}$. Metody wielowymiarowe są wrażliwe na zmianę struktury „prawdziwego" modelu gospodarki oraz wymagają możliwie precyzyjnego oszacowania jego parametrów. Co więcej, Vetlov i in. (2011) porównują zasadność użycia luki produkcyjnej oszacowanej na bazie nowokeynesistowskich modeli DSGE (tj. modeli dynamicznej stochastycznej równowagi ogólnej) ${ }^{31} \mathrm{z}$ jej jednowymiarowymi odpowiednikami, uzyskanymi za pomocą prostych metod. Wyniki pracy Vetlova $\mathrm{i}$ in. wskazują, że ze względu na siłę korelacji badanych miar luki produkcyjnej z inflacją ${ }^{32}$ wybór metody oszacowania luki nie ma większego znaczenia (choć różnice stają się widoczne, gdy pod uwagę weźmiemy trafność prognoz inflacji). $Z$ tego powodu, podobnie jak w większości analiz makroekonometrycznych, będziemy korzystać z metod jednowymiarowych, tj. trendu deterministycznego i pomocniczo filtru Hodricka-Prescotta.

\section{Uogólniona metoda momentów}

W modelach ekonometrycznych zawierających oczekiwania wśród zmiennych objaśniających, nie możemy wykorzystywać tradycyjnych metod estymacji parametrów strukturalnych (np. klasycznej MNK - zob. zob. np. Osińska, 2000, s. 70-75; Welfe, 2009, 211-213). Jednym z proponowanych rozwiązań jest zastosowanie estymatora należącego do szerokiej klasy estymatorów uogólnionej metody momentów.

Uogólniona metoda momentów ${ }^{33}$ (Generalised Method of Moments, GMM) została zaproponowana przez Hansena (1982) ${ }^{34}$. Jej działanie można opisać następująco. Po pierwsze, znajdujemy $Q$ równań zawierających momenty wektora zmiennych losowych, odpowiadających założeniom modelu statystycznego (nazywanych dalej „teoretycznymi warunkami momentów”). Teoretyczne warunki momentów są postaci:

$$
E[f(\boldsymbol{y}(t), \boldsymbol{\alpha})]=\mathbf{0}
$$

${ }^{30}$ Klasyfikację taką przyjmuje wiele prac poświęconych pomiarowi luki - np. Dupasquier, Guay, St-Amant (1999), Statistical Methods... (2003), a w literaturze polskiej np. Krajewski (2006, s. 108-109).

${ }^{31}$ Tej klasy modele wykorzystywać będziemy w analizach prezentowanych w rozdz. 4.

${ }^{32} \mathrm{~W}$ tym także korelacje z inflacją opóźnioną lub przyspieszoną w stosunku do luki produkcyjnej.

${ }^{33}$ Hall (2005, s. 15) wskazuje, że nazwa pochodzi od Simsa, który obliczał parametry wykorzystując liniową kombinację momentów (aczkolwiek sam Sims nie stawiał celu w postaci formalnej minimalizacji wyrażenia (8)).

${ }^{34} \mathrm{~W}$ roku 2013, m.in. za prace nad tą metodą, otrzymał on Nagrodę Banku Szwecji im. Alfreda Nobla, wspólnie z E. Famą oraz R. Schillerem, www.nobelprize.org. 
gdzie:

$\boldsymbol{\alpha}$-wektor $K$ parametrów modelu,

$\boldsymbol{y}(t)$ - wektor zmiennych losowych (w okresie $t$ ).

Analogiczne równania (nazywane dalej ,empirycznymi warunkami momentów”) zapisujemy zastępując momenty teoretyczne ich realizacjami wyliczonymi z próby, warunkowo względem $K$ estymowanych parametrów. Oznaczmy:

$f_{T}(\boldsymbol{Y}, \boldsymbol{\alpha})=\frac{1}{T} \sum_{t=1}^{T} f(\boldsymbol{y}(t), \boldsymbol{\alpha})$ - wektor $Q$ momentów empirycznych, wyliczonych z $T$-elementowej próby,

$\boldsymbol{Y}=[\boldsymbol{y}(1) \ldots \boldsymbol{y}(T)]^{T}-$ macierz obserwacji zmiennych w modelu.

Wówczas podstawienie empirycznych warunków momentów do wyrażenia (1.6) daje warunek ${ }^{35}$ :

$$
f_{T}(\boldsymbol{Y}, \boldsymbol{\alpha})=\frac{1}{T} \sum_{t=1}^{T} f(\boldsymbol{y}(t), \boldsymbol{\alpha})=\mathbf{0}
$$

Powyższe wyrażenie (1.7) stanowi układ $Q$ równań z $K$ niewiadomymi, który w ogólnym przypadku dla $Q>K$ nie ma rozwiązania. Zawsze jest jednak możliwe znalezienie parametrów $\alpha$, dla których lewa strona (1.6) jest „,blisko” wektora zerowego. Dlatego też estymacja nieznanych parametrów polega na znalezieniu takich parametrów, które zapewniają najmniejsze różnice teoretycznych warunków momentów od empirycznych warunków momentów. W tym celu minimalizuje się metrykę (normę) momentów o postaci:

$$
\left(f_{T}(\boldsymbol{Y}, \boldsymbol{\alpha})\right)^{T} W_{G M M}\left(f_{T}(\boldsymbol{Y}, \boldsymbol{\alpha})\right) \rightarrow \min
$$

gdzie:

$W_{G M M}$ - stochastyczna, półdodatnio określona macierz wag.

Estymator GMM formalnie definiujemy jako:

$$
\boldsymbol{\alpha}=\operatorname{argmin}\left[\left(f_{T}(\boldsymbol{Y}, \boldsymbol{\alpha})\right)^{T} W_{G M M}\left(f_{T}(\boldsymbol{Y}, \boldsymbol{\alpha})\right)\right]
$$

Przy stosunkowo ogólnych założeniach estymator GMM jest asymptotycznie nieobciążony i zgodny. Jego efektywność zależy natomiast od wyboru macierzy $W_{G M M}$ (Harris, Matyas, 1999, s. 11 i n.). Optymalna macierz wag zapewnia minimalną (asymptotyczną) wariancję estymatora parametrów $\alpha$ (zob. Hall, 2005, s. 43-44). Warunek ten zapewnia macierz wag równa odwrotności macierzy wariancji-kowariancji momentów z próby $W_{G M M}=S^{-1}$. Nie rozwiązuje to jednak

${ }^{35}$ Oczywiście zastąpienie warunków teoretycznych empirycznymi ma sens tylko wtedy, gdy momenty empiryczne są , dobrymi” estymatorami warunków teoretycznych. 
problemu, jako że macierz wariancji-kowariancji jest zwykle nieznana (m.in. w ogólnym przypadku zależy od parametrów modelu), stąd powinna być estymowana za pomocą dwustopniowej procedury. W pierwszym kroku przyjmuje się dowolny zgodny estymator $\alpha$ (np. $W_{G M M}=I$ ). W drugim kroku, wykorzystując wstępne oceny parametrów wylicza się macierz $W_{G M M}$ zapewniającą efektywną estymację (szerzej: Hall, 2005, rozdz. 2.4).

Hansen i in (1996) zaproponowali procedurę wielokrotnej aktualizacji macierzy $W_{G M M}$, aż do uzyskania zbieżności kolejno otrzymywanych macierzy (Continuous Updating Estimator, dalej: GMM-CUE). Estymator ten jest bardziej efektywny w krótkich próbach, a ponadto jest bardziej odporny np. na występowanie opisanego poniżej problemu ,słabych instrumentów”. Estymator ten będzie wykorzystywany w dalszych obliczeniach.

W pracy wykorzystywać będziemy estymator GMM do estymacji parametrów w liniowym modelu regresji ze zmiennymi objaśniającymi $(\boldsymbol{x}(t))$ skorelowanymi ze składnikiem losowym. W takiej sytuacji nie mogą zostać wykorzystane standardowe warunki momentów oparte na założeniu o zerowej kowariancji składnika losowego i zmiennych objaśniających (np. w regresji za pomocą KMNK). Zamiast tego poszukuje się zmiennych $Q$ instrumentalnych, co do których zakłada się, iż są one nieskorelowane ze składnikiem losowym. W rezultacie tego założenia otrzymujemy wektor $Q$ warunków momentów:

$$
E\left(z(t) \varepsilon_{t}\right)=0
$$

gdzie:

$z(t)$ - wektor obserwacji $Q$ zmiennych instrumentalnych (w okresie $t$ ), $\varepsilon_{t}-$ składnik losowy w chwili $t$.

W omawianym przypadku macierz obserwacji zmiennych w modelu składa się ze zmiennej objaśnianej, zmiennych objaśniających oraz zmiennych instrumentalnych - tj. $\boldsymbol{Y}=\left[\boldsymbol{y}_{T \times 1} \boldsymbol{X}_{T \times K} \boldsymbol{Z}_{T \times Q}\right]^{T}$ przyjmując konwencję podaną pod wzorem (1.6), a estymator GMM jest dany następującym wzorem (zob. np. Canova, 2007, s. 170) ${ }^{36}$ :

$$
\hat{\boldsymbol{\alpha}}=\left(\boldsymbol{X}^{T} \boldsymbol{Z} \boldsymbol{W}_{G M M} \boldsymbol{Z}^{T} \boldsymbol{X}\right)^{-1} \boldsymbol{X}^{T} \boldsymbol{Z} \boldsymbol{W}_{G M M} \boldsymbol{Z}^{T} \boldsymbol{y}
$$

gdzie:

$\hat{\alpha}$ - wektor ocen parametrów,

$\boldsymbol{y}$ - wektor obserwacji zmiennej objaśnianej,

${ }^{36}$ Dla szczególnego przypadku, w którym zakłada się sferyczność składników losowych, estymator ten redukuje się do podwójnej MNK. Analogia ta będzie pomocna w objaśnianiu testowania hipotezy o „słabych instrumentach”. 


$$
\begin{aligned}
\boldsymbol{X} & =[\boldsymbol{x}(1) \ldots \boldsymbol{x}(T)]^{T}-\text { macierz obserwacji zmiennych objaśniających, } \\
\boldsymbol{Z} & =[\boldsymbol{z}(1) \ldots \boldsymbol{z}(T)]^{T}-\text { macierz obserwacji zmiennych instrumentalnych. }
\end{aligned}
$$

Jednym z najczęściej wykorzystywanych estymatorów wariancji-kowariancji (a co za tym idzie - macierzy wag) został zaproponowany przez Neweya i Westa (1987). Taka macierz wag zapewnia efektywną estymację parametrów w przypadku występowania heteroskedastyczności lub autokorelacji rzędu maksymalnie $R$ (tzw. HAC). Podejście to zapewnia zgodną estymację optymalnej macierzy wag, a przy tym spełnienie warunku półdodatniej określoności tej macierzy (dzięki wykorzystaniu poprawek Bartletta):

$$
\hat{\boldsymbol{S}}=\boldsymbol{\Omega}_{\mathbf{0}}+\sum_{j=1}^{R} W_{j}\left(\boldsymbol{\Omega}_{j}-\boldsymbol{\Omega}_{j}^{\mathrm{T}}\right)
$$

gdzie:

$\boldsymbol{\Omega}_{\mathbf{0}}$ - macierz wariancji-kowariancji momentów z próby,

$\boldsymbol{\Omega}_{j}$ - macierz autokowariancji j-tego rzędu momentów z próby,

$w_{j}$ - poprawki Bartletta, wyznaczane według formuły: $w_{j}=1-\left(\frac{j}{R+1}\right)$.

W przypadku gdy $Q=K$, lewa strona wyrażenia (1.8) osiąga minimalną wartość równą zero niezależnie od wyboru $W_{G M M}$ (dzieje się to wtedy i tylko wtedy gdy $\left.f_{T}(\boldsymbol{Y}, \boldsymbol{\alpha})=\mathbf{0}\right)^{37}$. Dzięki wykorzystaniu dodatkowej informacji o momentach (mówimy wówczas o warunkach nad-identyfikujących) możliwe jest testowanie istotności nad-identyfikujących warunków momentów, a co za tym idzie zasadności przyjęcia danego zestawu założeń ${ }^{38}$. W tym celu korzystamy z testu Sargana-Hansena, w którym stawia się następujący zestaw hipotez:

$$
\begin{aligned}
& H_{0}: E\left(\mathbf{z}(t) \varepsilon_{t}\right)=\mathbf{0} \\
& H_{1}: E\left(\mathbf{z}(t) \varepsilon_{t}\right) \neq \mathbf{0}
\end{aligned}
$$

Sprawdzianem tego testu jest statystyka $J$ o rozkładzie chi-kwadrat o $Q-K$ stopniach swobody (tj. ilości nad-identyfikujących warunków momentów):

$$
J=\left[f_{T}(\boldsymbol{Y}, \boldsymbol{\alpha})\right]^{T} \boldsymbol{W}_{G M M}\left[f_{T}(\boldsymbol{Y}, \boldsymbol{\alpha})\right]
$$

Spełnienie warunku nieskorelowania instrumentów ze składnikiem losowym nie gwarantuje jeszcze prawidłowego wyboru instrumentów. W przypadku, gdy instrumenty nie są skorelowane ze zmiennymi objaśniającymi, estymator

${ }^{37}$ Ponownie sięgnijmy do analogii z KMNK, gdzie $Q=K$ warunków momentów korzysta z założenia o nieskorelowaniu zmiennych objaśniających ze składnikiem losowym.

${ }^{38} \mathrm{~W}$ przypadku, który stosujemy w pracy testowanie de facto dotyczyć będzie zasadności przyjęcia danego zestawu instrumentów. 
nie wykorzystuje informacji zawartych w zmiennych objaśniających (zob. Hall, 2005; s. 298-303). Dlatego też wymaga się, aby przyjęty zestaw instrumentów dobrze opisywał zmienne objaśniające. W przeciwnym przypadku model jest nieidentyfikowalny co do zmiennych objaśniających (przypadek taki określany jest również mianem tzw. „słabych instrumentów”), a w rezultacie estymator GMM jest asympotycznie obciążony ${ }^{39}$ i ma niestandardowy rozkład (Dufour, 2003; Murray, 2006). Formalne testy nieidentyfikowalności co do zmiennych objaśniających polegają na testowaniu łącznej istotności parametrów w równaniach wiążących zmienne instrumentalne ze zmiennymi objaśnianymi. W przypadku dwustopniowej MNK, można skorzystać ze standardowego testu łącznej istotności opartego na statystyce $F$ (tzw. test Andersona-Rubina), zaś dla przypadku potencjalnie niesferycznych składników losowych (typowego dla GMM) zaproponowano inne testy. W dalszych badaniach empirycznych zastosujemy test Kleibergena i Paap (2006), gdzie testuje się hipotezę mówiącą, iż macierz parametrów wiążących zmienne objaśniające $\mathrm{i}$ instrumenty jest zerowa ${ }^{40}$.

Testowanie instrumentów, zarówno pod kątem nieskorelowania ze składnikiem losowym, jak i silnego objaśniania zmiennych objaśniających, pozwala zatem wykluczyć niektóre zestawy instrumentów. Nie wskazuje jednak, który z dwu lub więcej „poprawnych” zestawów instrumentów powinien zostać wykorzystany. Andrews (1999) zaproponował kryteria pozwalające na określenie optymalnego zestawu instrumentów, analogiczne do kryteriów informacyjnych Akaike’a i Schwarza (służących np. do określenia długości opóźnień w modelach szeregów czasowych - zob. np. Maddala, 2006, s. 591). Kryteria te pozwalają na minimalizację statystyki $J$, faworyzując przy tym specyfikacje z relatywnie niewielką liczbą instrumentów. Kryteria te nie zyskały dużej popularności w badaniach empirycznych. W większości takich badań zmienne instrumentalne początkowo dobiera się według subiektywnej oceny spełnienia dwu warunków: nieskorelowania ze składnikiem losowym oraz silnego skorelowania ze zmiennymi objaśniającymi, a następnie testuje się ich spełnienie ${ }^{41}$. W taki właśnie sposób będziemy dobierać zmienne instrumentalne w dalszej części pracy, a dodatkowo sprawdzimy wrażliwość wyników na zmiany w zestawie instrumentów.

${ }^{39}$ Podobnie jak w przypadku pominięcia ważnej zmiennej objaśnianej w klasycznej regresji (zob. np. Maddala, 2006, s. 199-201).

${ }^{40}$ Ściślej rzecz biorąc, że jest zerowego rzędu.

${ }^{41}$ Zwróćmy uwagę, że taki sposób doboru zmiennych instrumentalnych nie odbiega od standardowej procedury doboru zmiennych objaśniających w klasycznej regresji. 


\section{Załącznik 1.1. \\ Model niespójności polityki gospodarczej \\ Kydlanda i Prescotta}

Stan gospodarki w każdym z dwu okresów ${ }^{42}$ jest opisany przez dwie zmienne. Zmienna $x$ stanowi instrument polityki gospodarczej, jest więc przedmiotem wyboru decydenta. Kształtowanie się zmiennej $x$ w pierwszym okresie zależy wyłącznie od bieżącej i przyszłej polityki gospodarczej:

$$
x_{1}=f_{1}\left(i_{1}, i_{2}\right)
$$

Natomiast $\mathrm{w}$ drugim okresie wartość zmiennej $x$ zależy od polityki gospodarczej w obu okresach oraz od jej realizacji w okresie poprzednim (pierwszym):

$$
x_{2}=f_{2}\left(x_{1}, i_{1}, i_{2}\right)
$$

Społeczna funkcja straty jest funkcją wartości wszystkich zmiennych:

$$
S\left(x_{1}, x_{2}, i_{1}, i_{2}\right)
$$

Celem decydenta jest minimalizacja społecznej funkcji straty (Z1-3). Warunkiem koniecznym dla tak rozumianej optymalnej polityki gospodarczej w okresie drugim jest zerowa pochodna funkcji (Z1-3) względem $i_{2}$. W okresie pierwszym, biorąc pod uwagę równania $(Z 1-1)$ i (Z1-2), wynosi ona:

$$
\frac{\partial S\left(x_{1}, x_{2}, i_{1}, i_{2}\right)}{\partial i_{2}}=\frac{\partial S}{\partial x_{1}} \frac{\partial f_{1}}{\partial i_{2}}+\frac{\partial S}{\partial x_{2}} \frac{\partial f_{2}}{\partial x_{1}} \frac{\partial f_{1}}{\partial i_{2}}+\frac{\partial S}{\partial x_{2}} \frac{\partial f_{2}}{\partial i_{2}}+\frac{\partial S}{\partial i_{2}}=0
$$

Z kolei w drugim okresie wartości $x_{1}$ i $i_{1}$ są ustalone, wobec czego warunek konieczny optymalizacji przedstawia się następująco:

$$
\frac{\partial S\left(x_{1}, x_{2}, i_{1}, i_{2}\right)}{\partial i_{?}}=\frac{\partial S}{\partial x_{2}} \frac{\partial f_{2}}{\partial i_{?}}+\frac{\partial S}{\partial i_{?}}=0
$$

Zgodnie z definicją Kydlanda i Prescotta, polityka gospodarcza jest spójna $\mathrm{w}$ czasie wtedy i tylko wtedy gdy warunki optymalizacji w obu okresach (tj. (Z1-4) i (Z1-5)) są tożsame. Zachodzi to, gdy suma dwóch pierwszych

${ }^{42}$ Rozpatrzymy najprostszy przypadek, tj. 2 okresy. Uogólnienie na więcej okresów komplikuje obliczenia, ale nie zmienia głównych wniosków. 
składników prawej strony wyrażenia (Z1-4) wynosi zero, co można zapisać następująco: $\frac{\partial f_{1}}{\partial x_{2}}\left(\frac{\partial S}{\partial x_{1}}+\frac{\partial S}{\partial x_{2}} \frac{\partial f_{2}}{\partial x_{1}}\right)=0$. W ogólnym przypadku trudno się spodziewać, aby $\left(\frac{\partial S}{\partial x_{1}}+\frac{\partial S}{\partial x_{2}} \frac{\partial f_{2}}{\partial x_{1}}\right)$ był równy zeru ${ }^{43}$, a zatem spełnienie tego warunku zapewniać może jedynie $\frac{\partial f_{1}}{\partial x_{2}}=0$. Równość ta oznacza brak reakcji bieżącego stanu gospodarki na zmianę sposobu prowadzenia polityki gospodarczej w przyszłości, co ma miejsce np. w przypadku gdy polityka ta oparta jest na regułach.

Powyższy, bardzo ogólny wynik możemy odnieść do polityki pieniężnej, przyjmując że bank centralny ustala inflację ${ }^{44} \mathrm{~W}$ warunkach ograniczenia równaniem podaży Lucasa bądź krzywą Phillipsa wzmocnioną oczekiwaniami. W takim przypadku niespójność w czasie polegać może na tym, że polityka pieniężna może być nadmiernie ekspansywna w drugim okresie, powodując inflację (w podobny sposób przedstawiają to również Barro i Gordon - zob. Załącznik 1.2).

\section{Załącznik 1.2. \\ Niespójność polityki pieniężnej w modelach Barro i Gordona}

W niniejszym załączniku syntetycznie prezentujemy modele skonstruowane przez Barro i Gordona (1983a, 1983b), z tym jednak że korzystamy z krzywej Phillipsa $\mathrm{z}$ wielkością produkcji a nie bezrobociem (jak w oryginalnej wersji). Nieco inne ujęcia tego zagadnienia w literaturze polskojęzycznej czytelnik znajdzie np. w podręcznikach: Snowdon, Vane i Wynarczyk (1998, rozdz. 5.4.3, s. 216-221), Romer (2000, rozdz. 9.4, s. 433-438), Acocella (2002, rozdz. 19.1, s. 524-528) oraz Dudek (2008, s. 33 i n.).

$\mathrm{W}$ prezentowanym modelu bank centralny prowadzi politykę pieniężną, której celem jest utrzymanie zerowej inflacji $\left(\pi_{t}=0\right)$, jednocześnie przy możliwie najwyższej produkcji $\left(y_{t}\right)$. Formalnie cel taki można wyrazić w postaci następującej kwadratowo-liniowej funkcji straty, którą minimalizuje bank centralny ${ }^{45}$ :

${ }^{43}$ Dodajmy na marginesie, że wyrażenie to nie posiada sensownej interpretacji ekonomicznej.

${ }^{44} \mathrm{~W}$ tym miejscu w celu uproszczenia analiz zakładamy, że bank centralny w pełni kontroluje inflację, a tym samym abstrahujemy od zewnętrznych szoków.

${ }^{45} \mathrm{~W}$ prezentowanym modelu możliwe jest zastąpienie celu zerowej inflacji przy pomocy celu na innym, z góry założonym poziomie (np. poziomie optymalnym z punktu widzenia tempa wzrostu gospodarczego), jak również wprowadzenie funkcji straty kwadratowej względem inflacji i odchylenia produkcji od produkcji pożądanej przez bank centralny. Modyfikacje takie nie zmieniają głównych wniosków, a jedynie prowadzą do bardziej złożonych obliczeń. 


$$
Z_{t}=\frac{1}{2} W_{\pi} \pi_{t}^{2}-y_{t} \rightarrow \min
$$

gdzie:

$Z_{t}$ - wartość funkcji straty w okresie $t$,

$W_{\pi}$ - waga przypisana odchyleniu inflacji od celu w funkcji straty,

$\pi_{t}$ - inflacja w okresie $t$,

$y_{t}$ - produkcja w okresie $t$.

Ponadto zakłada się, że inflację opisuje równanie krzywej Phillipsa wzmocnionej oczekiwaniami, w postaci:

$$
\pi_{t}=E_{t-1} \pi_{t}+\alpha\left(y_{t}-y^{n}\right)
$$

Ogólnie rzecz biorąc możemy wyróżnić trzy sposoby prowadzenia polityki pieniężnej (Barro i Gordon, 1983b):

i. bank centralny deklaruje zerową inflację, a następnie ignoruje to zobowiązanie,

ii. bank centralny działa według reguły - deklaruje zerową inflację i wypełnia to zobowiązanie,

iii. polityka uznaniowa.

W pierwszych dwu przypadkach bank centralny deklaruje, że inflacja wyniesie zero a wszystkie podmioty gospodarcze wierzą $\mathrm{w}$ to zapewnienie, wobec czego można przyjąć $E_{t-1} \pi_{t}=0$.

W pierwszym przypadku bank centralny traktuje oczekiwania jako ustalone (egzogeniczne). Po rozwiązaniu (Z2-2) ze względu na lukę produkcyjną $\left(y_{t}-y^{n}\right)$, a następnie wstawienie takiego wyrażenia do funkcji celu (Z2-1), otrzymujemy warunek konieczny maksymalizacji:

$$
\frac{\partial Z_{t}}{\partial \pi_{t}}=w_{\pi} \pi_{t}-\frac{1}{2}=0
$$

Z rozwiązania powyższego warunku wynika, że inflacja wyniesie $\pi_{t}=\frac{1}{\alpha w_{\pi}}$, wobec czego aby spełniona była krzywa Phillipsa, produkcja musi być na poziomie $y_{t}=y^{n}+\frac{1}{w_{\pi}(\alpha)^{2}}$. To z kolei implikuje wartość funkcji straty $Z_{t}=\frac{1}{2 w_{\pi}(\alpha)^{2}}-y^{n}-\frac{1}{w_{\pi}(\alpha)^{2}}=\frac{-1}{2 w_{\pi}(\alpha)^{2}}-y^{n}$.

Natomiast w przypadku wdrożenia reguły bank centralny traktuje swoje zobowiązanie jako wiążące, co oznacza, że wyznacza inflację na poziomie zadeklarowanym wcześniej, tj. $\pi_{t}=E_{t-1} \pi_{t}$. Wyrażenie to jest spełnione wtedy i tylko 
wtedy, gdy produkcja jest na poziomie naturalnym ( $\left.\mathrm{tj} \cdot y_{t}-y^{n}\right)$. Po rozwiązaniu (Z2-1) ze względu na lukę produkcyjną, a następnie wstawienie takiego wyrażenia do funkcji celu (Z2-1), otrzymujemy warunek konieczny maksymalizacji w postaci:

$$
\frac{\partial Z_{t}}{\partial \pi_{t}}=W_{\pi} \pi_{t}=0
$$

W takim przypadku $\pi_{t}=0$, co implikuje wartość funkcji straty $Z_{t}=-y^{n}$.

W trzecim przypadku podmioty oczekują, że bank centralny będzie prowadził ekspansywną politykę pieniężną i ustali inflację na poziomie wynikającym $\mathrm{z}$ optymalizacji. Zatem inflacja wyniesie tyle samo co w pierwszym przypadku, $\mathrm{z}$ tą jednak różnicą że będzie ona $\mathrm{w}$ pełni antycypowana przez podmioty gospodarcze. W efekcie mamy: $\pi_{t}=E_{t-1} \pi_{t}=\frac{1}{\alpha w_{-}}$, co zachodzi przy produkcji na poziomie naturalnym. To z kolei implikuje wartość funkcji straty $Z_{t}=\frac{1}{2 w_{\pi}(\alpha)^{2}}-y^{n}$.

Porównując wartości funkcji straty dla poszczególnych rozwiązań moglibyśmy przypuszczać, że niezależnie od wielkości parametrów, najlepszym rozwiązaniem byłoby rozwiązanie pierwsze, które może być interpretowane jako zapowiedź niskiej inflacji w połączeniu z ekspansywną polityką pieniężną. Powtarzalność „gry” banku centralnego z podmiotami gospodarczymi wyklucza w długim okresie taki przypadek, bowiem w rzeczywistości trudno jest uzasadnić systematyczne błędy oczekiwań. Jeśli zatem w długim okresie inflacja jest równa oczekiwanej, co odpowiada zarówno przypadkowi oczekiwań adaptacyjnych, jak i racjonalnych, wówczas $\mathrm{w}$ długim okresie ekspansja monetarna nie przyniesie zwiększenia produktu (który pozostanie na poziomie naturalnym).

Z powyższego wynika, że spośród rozwiązań spójnych w czasie, bank centralny dysponuje zatem rozwiązaniem (ii) i (iii), przy czym, niezależnie od przyjętych parametrów, rozwiązanie drugie (reguła) pozwala zawsze osiągnąć niższą wartość funkcji straty. 


\section{REGULA TAYLORA ORAZ JEJ ROZSZERZENIA - PRZEGLĄD BADAŃ}

\section{Wprowadzenie}

W rozdziale dokonamy przeglądu rozwiązań stosowanych w badaniach nad regułą stopy procentowej zaproponowanej przez Taylora (1993) oraz jej modyfikacji. Przegląd ten stanowić będzie podstawę empirycznej oceny reguł w Polsce, przedstawionej w dalszej części pracy. Mając to na uwadze, w wielu przypadkach ocenimy możliwość i celowość empirycznej weryfikacji prezentowanych wariantów reguły Taylora opierając się na danych dla Polski.

W niniejszym przeglądzie skoncentrujemy się na następujących zagadnieniach szczegółowych: (i) charakterze stopy procentowej podlegającej wyjaśnieniu, (ii) specyfikacji dynamicznej równania oraz zasadności wykorzystania danych dostępnych w czasie podejmowania decyzji (real-time data), (iii) możliwości poszerzenia zbioru zmiennych objaśniających, (iv) sposobie pomiaru zmiennych objaśniających, (v) postaci funkcyjnej oraz (vi) stabilności parametrów równania. Na koniec wskażemy najczęściej spotykane zastosowania reguły Taylora.

\section{Regula stopy procentowej J.B. Taylora}

Niemal wszystkie współczesne reguły stopy procentowej wywodzą się z prostego równania zaproponowanego przez J.B. Taylora (1993). Równanie to, nazwane później „regułą Taylora”, wiązało wysokość krótkookresowych nominalnych stóp procentowych z odchyleniami inflacji od poziomu docelowego (pożądanego przez władze monetarne - „celu inflacyjnego" ${ }^{\text {) }}$ oraz PKB od potencjalnego PKB (luką produkcyjną):

$$
i_{t}=i_{0}+\phi_{\pi}\left(\pi_{t}-\bar{\pi}\right)+\phi_{x} x_{t}
$$

gdzie:

$i_{t}$ - nominalna stopa procentowa,

${ }^{1}$ Wykorzystanie cudzysłowu jest nieprzypadkowe, gdyż Taylor przedstawił swoją regułę jako opis polityki pieniężnej prowadzonej w Stanach Zjednoczonych, gdzie cel inflacyjny nie jest ogłaszany (zob. np. Kokoszczyński, 2004, s. 72-75). 
$\pi_{t}$ - stopa inflacji,

$\bar{\pi}$ - docelowa inflacja,

$x_{t}-$ luka produkcyjna,

$\phi_{\pi}, \phi_{x}, i_{0}$ - parametry strukturalne.

Po skalibrowaniu parametrów przez Taylora (1993), reguła ta wyglądała następująco ${ }^{2}$ :

$$
i_{t}=4+1,5\left(\pi_{t}-\bar{\pi}\right)+0,5 x_{t}
$$

Jak wynikało z symulacji przeprowadzonych przez samego Taylora, ta prosta reguła stosunkowo dobrze opisywała zmiany stóp procentowych w USA w okresie od I kwartału 1987 do III kwartału 1992.

Analizy oparte na równaniu zaproponowanym przez Taylora były weryfikowane i rozszerzane przez innych badaczy. Przegląd tych rozszerzeń oraz podejść metodologicznych stosowanych w analizach teoretycznych i badaniach empirycznych będzie przedmiotem dalszej części rozdziału.

\section{Reguła Taylora - przegląd dotychczasowych badań}

\section{Zmienna objaśniana}

Pierwszą wątpliwością, w zasadzie dotyczącą jedynie prac empirycznych, jest rodzaj stopy procentowej podlegającej objaśnieniu. Wykorzystanie reguły Taylora do oszacowania funkcji reakcji oraz prognozowania decyzji organów decyzyjnych banków centralnych skłania niektórych autorów do skorzystania z jednej ze stóp procentowych ustalanych przez bank centralny (tzw. oficjalnej stopy procentowej, obecnie w Polsce: depozytowej, referencyjnej i lombardowej). Modele opisujące oficjalne stopy banku centralnego najczęściej stosują alternatywne podejście metodologiczne. Wykorzystuje ono fakt, że zmiany stóp procentowych są zawsze wielokrotnością pewnej wartości (zwykle 0,25 p. proc.). W takim przypadku należy stosować modele zmiennych wielomianowych (dyskretnych) uporządkowanych (ordered logit bądź ordered probit) ${ }^{3}$, co zwykle sprowadza się jedynie do badania znaku zmiany stóp procentowych (podwyższenie, pozostawienie bez zmian albo obniżenie stóp). W ten sposób dokonano m.in. analizy decyzji: Banku Anglii (Gascoigne, Turner, 2004), Europejskiego Banku

\footnotetext{
${ }^{2}$ Oryginalna postać reguły wyglądała następująco: $i_{t}=\pi_{t}+0,5\left(\pi_{t}-2\right)+0,5 x_{t}+2$. $\mathrm{W}$ pracy stosujemy zapis porównywalny z nowszymi badaniami.

${ }^{3}$ Szerszy opis tych modeli przedstawiają np. Greene (2003, s. 736 i n.) i Verbeek (2012, s. 221 i n.), a w literaturze polskiej: Gruszczyński (2012, rozdz. 4).
} 
Centralnego (Carstensen, 2006; Sturm, den Haan, 2011) oraz Narodowego Banku Polskiego (Kotłowski, 2006) ${ }^{4}$. Nieco inną klasę modeli, jaką stanowią modele zmiennych wielomianowych nieuporządkowanych (multinomial logit), zastosowano do modelowania zmian stóp procentowych banku centralnego Zachodnioafrykańskiej Unii Gospodarczo-Walutowej (Shortland, Stasavage, 2004). W naszej ocenie ostatnia $\mathrm{z}$ wymienionych metod nie powinna być stosowana do modelowania zmiany stóp procentowych (czyli typowego przypadku zmiennej mierzonej na skali porządkowanej). W przypadku, gdy podejrzewa się asymetrię reakcji polityki pieniężnej na zmienne objaśniające w zależności od kierunku zmian stopy, należałoby raczej zastosować uogólnione modele dla zmiennej nieuporządkowanej (zob. Gruszczyński, 2012, s. 146-147). Nowsze badania, bardziej wyrafinowane metodologicznie, korzystają z dynamicznych modeli zmiennych wielomianowych ${ }^{5}$. Kauppi (2007) wykorzystał dynamiczną wersję modelu probitowego dla zmiennej nieuporządkowanej do prognozy zmian stóp procentowych Banku Rezerwy Federalnej, zaś Tae-Hwan i in. (2008) weryfikowali zdolność prognozowania zmian stóp procentowych w Wielkiej Brytanii przez dynamiczny model ordered probit.

Wykorzystanie oficjalnych stóp procentowych do opisu sposobu prowadzenia polityki pieniężnej budzi pewne wątpliwości. W literaturze podkreśla się, że operacje otwartego rynku stanowią bardzo dobre narzędzie wpływu banku centralnego na gospodarkę - są precyzyjne (bank centralny może przeprowadzić je na dowolnie małą skalę), w pełni kontrolowane i „odwracalne” (bank centralny decyduje o rozmiarze tych operacji i w razie potrzeby może przeprowadzić transakcje „odwrotne”), a ich efekty są szybko widoczne (zob. Mishkin, Eakins, 1998, s. 618). Dlatego też operacje otwartego rynku, wpływające na krótkookresową rynkową stopę procentową, są obecnie najważniejszym narzędziem prowadzenia polityki pieniężnej są (por. np. Romer, 2001; Mishkin, 2002, rozdz. 18, s. 569 i n.; Polański, 2004, s. 132-133; Cendal, 2008a, s. 133-134; Tymoczko, 2011). Podobne stanowisko prezentuje również Narodowy Bank Polski:

NBP wpływa na poziom inflacji przede wszystkim poprzez określanie wysokości oficjalnych stóp procentowych, które wyznaczają rentowności instrumentów polityki pieniężnej. W celu kształtowania krótkoterminowych stóp procentowych na rynku pieniężnym NBP wykorzystuje nowoczesne instrumenty polityki pieniężnej, w tym:

- operacje otwartego rynku,

- operacje depozytowo-kredytowe,

- rezerwę obowiązkową.

Operując wymienionymi instrumentami, NBP dąży do kształtowania takiego poziomu stóp procentowych w gospodarce, który maksymalizuje prawdopodobieństwo osiągnięcia celu inflacyjnego. (www.nbp.pl)

\footnotetext{
${ }^{4} \mathrm{Z}$ takiego podejścia pomocniczo korzystali również Dolado i in. (2005).

${ }^{5}$ Podejście takie jest uzasadnione faktem wygładzania stóp procentowych. Zagadnienie to opiszemy w następnej części opracowania.
} 
Stopa rynkowa jest kształtowana przez wszystkie wymienione instrumenty, stanowi zatem dobrą syntetyczną miarę restrykcyjności polityki pieniężnej. Dodatkowo do zastosowania rynkowej stopy procentowej skłania fakt, że podstawowa oficjalna stopa Narodowego Banku Polskiego (tj. stopa referencyjna) w okresie objętym analizą empiryczną w dalszej części pracy nie miała jednolitego charakteru. Przed 2008 rokiem stopa ta wyznaczała minimalną rentowność operacji otwartego rynku, natomiast po 2008 roku rentowność operacji otwartego rynku była równa stopie referencyjnej (zob. Założenia..., 2007). Dodatkowo zmieniała się zapadalność tych operacji (zob. tab. 2.1 oraz jej opis).

Dotychczasowe rozważania wskazują na celowość zastosowania rynkowej stopy procentowej, lecz nie wskazują powodów, dla których powinna to być stopa o krótkim terminie zapadalności (a tym bardziej jaki termin zapadalności powinno się stosować w badaniach polityki pieniężnej). Na gruncie teorii oczekiwań krzywej dochodowości (expectations theory of the term structure), długoterminowe stopy procentowe są wyznaczane przez sumę krótkookresowych stóp procentowych za kolejne okresy: bieżącej (spot) oraz przyszłej, oczekiwanej (forward) (zob. np. Jajuga, Jajuga, 2002, s. 62-64; Walsh, 2010, s. 465-466) ${ }^{6}$. Niespełnienie tego warunku oznaczałoby możliwość arbitrażu. W takim wypadku, przy założeniu stałej realnej stopy procentowej, racjonalnie działające podmioty będą oczekiwały zmian stóp procentowych zgodnych ze zmianami stopy inflacji. Wynika z tego, że lepszą miarą restrykcyjności aktualnej polityki pieniężnej jest krótkookresowa stopa procentowa, podczas gdy długookresowa stopa procentowa wyraża w większym stopniu oczekiwania co do przyszłego kształtowania się stóp procentowych, m.in. oczekiwane efekty polityki pieniężnej i fiskalnej, a także ryzyko wystąpienia szoków inflacyjnych (Shiller, 1990; Walsh, 2010, s. 468 i n.). Dlatego też empiryczne analizy reguły Taylora korzystają niemal wyłącznie ze stóp procentowych o krótkim okresie zapadalności - co najwyżej jednego miesiąca. Wynika to zapewne z faktu, że zapadalność podstawowych operacji otwartego rynku większości banków centralnych nie przekracza miesiąca7 ${ }^{7}$. Przykładowo w Europejskim Banku Centralnym standardowe operacje otwartego rynku mają zapadalność jednego tygodnia. W Polsce zapadalność operacji otwartego rynku ulegała zmianie, co przedstawiamy w tab. 2.1.

\footnotetext{
${ }^{6}$ Warunek ten jest spełniony dla niskich wartości stóp procentowych. Dla wyższych stóp należałoby stosować rachunek oparty na procencie składanym.

${ }^{7}$ Chodzi tu jedynie o podstawowe (standardowo stosowane) operacje otwartego rynku, a zatem abstrahujemy od nadzwyczajnych narzędzi polityki pieniężnej wykorzystywanych przez niektóre banki centralne do stymulowania gospodarki po 2008 r., a mających na celu kontrolę stóp procentowych o dłuższym okresie zapadalności (zob. np. Tymoczko, 2011, s. 130).
} 
Tabela 2.1. Zapadalność podstawowych operacji otwartego rynku w latach 1998-2012

\begin{tabular}{|l|c|}
\hline \multicolumn{1}{|c|}{ Okres } & Zapadalność operacji otwartego rynku \\
\hline Przed 2003 & $28 \mathrm{dni}$ \\
\hline $2003-2004$ & $14 \mathrm{dni}$ \\
\hline Od 2005 & $7 \mathrm{dni}$ \\
\hline
\end{tabular}

Źródło: opracowanie własne na podstawie: Instrumenty polityki pieniężnej (różne wydania).

Dodatkowo wskazanie najbardziej odpowiedniej stopy procentowej dla oceny polskiej polityki pieniężnej utrudnia fakt, że od 2008 roku Narodowy Bank Polski koncentruje się na kontroli stopy POLONIA o zapadalności overnight (zob. Założenia..., 2007, s. 10-11). Wykorzystanie tej stopy w naszych badaniach byłoby bardzo utrudnione ze względu na to, że jest ona notowana od końca stycznia 2005 (co dałoby jedynie ok. 30 obserwacji kwartalnych).

Dodajmy na koniec, że w praktyce dla Polski problem wyboru pomiędzy oficjalną stopą banku centralnego a stopą rynkową ma charakter formalny. Obserwujemy bowiem bardzo wysoką korelację stóp procentowych na rynku międzybankowym ze stopą referencyjną. Na przykład w próbie sięgającej od I kw. 1999 do III kw. 2012 (stosowanej w rozdz. 3 do estymacji reguły Taylora), współczynnik liniowej korelacji średnich w danym kwartale: jednomiesięcznej stopy WIBOR i stopy referencyjnej NBP wynosi 0,9987 (dla przyrostów otrzymano współczynnik korelacji równy 0,9471$)$.

\section{Specyfikacja dynamiczna}

Zwróćmy uwagę, że bank centralny nie obserwuje bieżącej inflacji ani luki produkcyjnej. Dostępne dane statystyczne publikowane są z opóźnieniem. Przykładowo, w Polsce wstępne informacje o dynamice kwartalnego PKB publikowane są z około dwumiesięcznym opóźnieniem (w stosunku do końca kwartału), w przypadku inflacji opóźnienie to sięga dwóch tygodni. Jeśli więc władze banku centralnego podejmują decyzje opierając się na oficjalnych publikacjach danych statystycznych, wówczas stosowane opóźnienia powinny zostać uwzględnione w modelu.

Wariant taki określa się mianem adaptacyjnego (backward looking):

$$
i_{t}=i_{0}+\phi_{\pi}\left(\pi_{t-k}-\bar{\pi}\right)+\phi_{x} x_{t-l}
$$

gdzie:

$k, l$ - rząd opóźnień, odpowiednio: odchylenia inflacji od celu oraz luki produkcyjnej. 
Wariant adaptacyjny nie jest jedynym możliwym ujęciem dynamiki reguły Taylora. Krytycy tego podejścia podkreślają znany wynik, że polityka pieniężna oddziałuje z opóźnieniem ${ }^{8}$, a co za tym idzie obecne ruchy stóp procentowych powinny raczej odzwierciedlać przyszłe, oczekiwane wartości zmiennych. Ważną rolę oczekiwanej inflacji podkreśla także Svensson (1997) wskazując, że w strategii bezpośredniego celu inflacyjnego nieformalnym celem pośrednim są prognozy inflacji.

Taki „wyprzedzający” sposób prowadzenia polityki pieniężnej opisuje antycypacyjny wariant reguły Taylora (forward looking):

$$
i_{t}=i_{0}+\phi_{\pi} \boldsymbol{E}_{t}\left(\pi_{t+n}-\bar{\pi}\right)+\phi_{x} \boldsymbol{E}_{t}\left(x_{t+m}\right)
$$

gdzie:

$n, m$ - horyzont czasowy oczekiwań, odpowiednio: odchylenia inflacji od celu i luki produkcyjnej,

$\boldsymbol{E}_{t}$ - operator racjonalnych oczekiwań, warunkowych względem zbioru informacji dostępnych w okresie $t$.

Sama koncepcja reakcji podmiotów gospodarczych na oczekiwane wartości zmiennych była znana w ekonomii na długo przed pojawieniem się reguły Taylora i była związana z hipotezą racjonalnych oczekiwań. Do omawianej reguły po raz pierwszy włączyli tę ideę Clarida, Gali i Gertler (1998)9.

Problemem przy oszacowaniu antycypacyjnej reguły Taylora jest brak danych odnośnie do prognoz banku centralnego ${ }^{10}$. W takim przypadku wszelkie analizy empiryczne wymagają przyjęcia założenia o sposobie formułowania prognoz. Ponadto, podobnie jak w wariancie adaptacyjnym, prawidłowy opis polityki pieniężnej powinien wykorzystywać szeregi typu real-time. Jednak w tym przypadku dane te nie są wykorzystywane bezpośrednio w równaniu, lecz stanowią podstawę do sporządzania prognoz.

$\mathrm{Z}$ wariantem antycypacyjnym wiążą się także pewne komplikacje metodologiczne. Ze względu na wpływ aktualnych szoków makroekonomicznych na prognozy (oczekiwania) inflacji oraz luki produkcyjnej, założenie o braku skorelowania zmiennych objaśniających ze składnikiem losowym nie jest spełnione. W tym przypadku do oszacowania parametrów modeli zawierających racjonalne

\footnotetext{
${ }^{8}$ Szacunki tego opóźnienia są dość zróżnicowane. Na przykład modele VAR zbudowane dla gospodarki Polski wskazują, że najsilniejsza reakcja inflacji na impuls stopy procentowej występuje po 4-7 kwartałach (Przystupa i Wróbel, 2006) lub po 3-4 kwartałach (Demchuk i in., 2012). Z kolei na podstawie modeli DSGE otrzymuje się analogiczne opóźnienie rzędu 1-4 kwartały (zob. Grabek, Kłos, Koloch, 2010; Kuchta, 2011; Baranowski, Szafrański, 2012).

${ }^{9}$ Nieco wcześniej Fuhrer i Moore (1997) brali pod uwagę podobny wariant w przypadku reguły Wicksellsa.

${ }^{10} \mathrm{~W}$ Polsce takich danych może dostarczyć projekcja inflacyjna. Jest ona jednak publikowana dopiero od sierpnia 2004 r. (trzy bądź cztery razy w roku) i stanowi prognozę warunkową przy dość silnym założeniu, że stopy procentowe nie ulegną zmianie.
} 
oczekiwania nie powinno się używać klasycznej MNK (zob. np. Osińska, 2000, s. 70-75; Welfe, 2009, s. 211-213). Jak już wspomniano, problem ten dotyczy oczywiście każdego innego modelu ekonometrycznego zawierającego racjonalne oczekiwania (w szczególności modeli DSGE wykorzystywanych w rozdz. 4), a w przypadku estymacji modelu jednorównaniowego bądź osobnej estymacji poszczególnych równań systemu najczęściej spotykanym jego rozwiązaniem jest zastosowanie Uogólnionej Metody Momentów (GMM), opisanej w rozdziale 1. W przypadku estymacji systemowej, zwykle stosuje się techniki bayesowskie, z tym że estymacji podlega postać „zredukowana” modelu DSGE (rozwiązanie ze względu na racjonalne oczekiwania, zapisane w postaci modelu przestrzeni stanów $)^{11}$.

Dodajmy, że „statyczna” reguła $^{12}$, zastosowana w pracy Taylora (1993) może być interpretowana jako szczególny rodzaj wariantu antycypacyjnego. Ze względu na opóźnienia w publikowaniu danych, bieżące dane odnośnie do zmiennych objaśniających nie są dostępne bankowi centralnemu, a zatem bank centralny może reagować na bieżące dane jedynie na podstawie oczekiwań - prognoz dotyczących bieżącego stanu gospodarki (tzw. nowcasting).

Podział na warianty: antycypacyjny i adaptacyjny nie jest rozłączny, niekiedy spotyka się także warianty pośrednie. Na przykład Garcia-Iglesias (2007) stwierdza, że polityka pieniężna prowadzona przez Europejski Bank Centralny reagowała z opóźnieniem (w sposób adaptacyjny) w stosunku do luki produkcyjnej, ale w sposób antycypacyjny w stosunku do inflacji. W nieco innym kontekście (określoności równowagi) takie warianty rozważa Wallusch (2013, s. 70-71).

Innym aspektem dynamiki równania Taylora jest hipoteza o wygładzonym przebiegu ścieżki stóp procentowych (interest rate smoothing). Zgodnie z nią zmiany stóp procentowych są rozłożone w czasie, tak że pojedyncze zmiany są niewielkie. Zachowanie takie opisuje model częściowych dostosowań, który można zapisać w następującej postaci (por. np. Woodford, 2003, s. 40-41; Walsh, 2010, s. 374-375) ${ }^{13}$ :

$$
i_{t}=\rho i_{t-1}+(1-\rho) i_{t}^{*}
$$

gdzie:

$i_{t}^{*}$ - stopa procentowa wynikająca z reguły Taylora (np. równań (2.1), (2.3) $\operatorname{lub}(2.4))$,

$\rho$ - parametr dostosowań (wygładzania stóp procentowych), z przedziału $(0,1)$.

${ }^{11}$ Warto podkreślić, że w przypadku modelu małej skali estymowanego dla Polski te dwie metody dają bardzo zróżnicowane wyniki, w szczególności w zakresie reakcji gospodarki na szok polityki pieniężnej (zob. Baranowski, Szafrański, 2012). Jednak w przypadku samej reguły Taylora różnice w ocenach parametrów są mniejsze niż w pozostałych równaniach modelu (tamże, tab. 4).

${ }^{12} \mathrm{~W}$ literaturze określana niekiedy również jako current looking (por. np. Lubik, Marzo, 2007).

${ }^{13}$ Równoważny zapis tego równania można przedstawić jako: $\Delta i_{t}=(1-\rho)\left(i_{t}^{*}-i_{t-1}\right)$. 
Jak wynika z zapisu równania (2.5), zmiana stopy procentowej w bieżącym okresie stanowić będzie jedynie $(1-\rho)$ część zmiany stóp procentowych jaka wynika z reguły Taylora. Dalsze dostosowania nastąpią w późniejszych okresach, przy czym ich wielkość będzie malała w postępie geometrycznym.

Równanie Taylora z wygładzaniem stóp procentowych było początkowo wynikiem analiz empirycznych (Mehra, 1997; Sack, 1998). W ślad za nimi pojawiły się następnie prace analizujące teoretyczne własności takich reguł (Rotemberg, Woodford, 1999). Jednak należy zauważyć, że sama koncepcja wygładzania stóp procentowych pojawiła się jeszcze przed publikacją Taylora (1993).

Już w latach 60. i 70. XX wieku rozważano zbliżoną koncepcję „gradualizmu” w polityce gospodarczej. Podkreślano tam, że szeroko rozumiana niepewność (np. co do ,prawdziwego" modelu gospodarki lub wynikająca z błędów pomiaru zmiennych) skłania ku ostrożnym, stopniowym reakcjom polityki gospodarczej ${ }^{14}$.

„Wygładzona" reakcja stopy procentowej na zmianę warunków gospodarczych może świadczyć o ostrożności banku centralnego, wydawałoby się nadmiernej i zmniejszającej skuteczność polityki pieniężnej. Taka reakcja może być jednak uzasadniona $\mathrm{w}$ przypadku, gdy zmienne objaśniające występujące w regule Taylora (zwłaszcza oszacowania luki produkcyjnej) są mierzone ze znacznym błędem (zob. Svennson, Woodford, 2003) lub gdy władze monetarne nie znają „prawdziwego" modelu gospodarki (lub choćby jego parametrów). Pierwszą z powyższych hipotez weryfikował Orphanides (2003). Na podstawie symulacji historycznych doszedł on do wniosku, że wzrost inflacji w Stanach Zjednoczonych pod koniec lat 60 . i na początku lat 70 . XX wieku wynikał w większym stopniu z błędnych szacunków luki niż samej uznaniowości w prowadzeniu polityki pieniężnej. Orphanides i Williams (2006) wskazują, że w przypadku niepewności co do szacunku naturalnej stopy procentowej najlepsze rezultaty osiąga reguła oparta na różnicach (tj. z parametrem wygładzania równym 1). Zdaniem Orphanidesa i Williamsa, dodatkową zaletą takiej reguły jest dość duża skuteczność również w sytuacji, gdy nie występuje niepewność co do naturalnej stopy procentowej. Innym motywem wygładzania stóp procentowych jest chęć ,wysyłania podmiotom gospodarczym jasnego sygnału" odnośnie do prowadzonej polityki, a także obawy co do postrzegania przez rynki finansowe kompetencji organów decyzyjnych (Wojtyna, 2004, s. 33). Oczywiście spotyka się także opinie krytyczne względem skuteczności „gradualistycznej” polityki pieniężnej (tamże, s. 32-33).

Po podstawieniu reguły Taylora (2.1) do równania (2.5) otrzymujemy następującą postać równania $\mathrm{z}$ wygładzaniem stóp procentowych (bardziej przydatną w analizach empirycznych):

$$
i_{t}=i_{0}^{*}+\rho i_{t-1}+\phi_{\pi}^{*}\left(\pi_{t}-\bar{\pi}\right)+\phi_{x}^{*} x_{t}
$$

${ }^{14}$ Ten typ argumentacji zapoczątkował Brainard (1967). 
Można zauważyć, że parametry w równaniach (2.1) i (2.5) spełniają następujące zależności:

$$
i_{0}^{*}=(1-\rho) i_{0}, \phi_{\pi}^{*}=(1-\rho) \phi_{\pi}, \phi_{x}^{*}=(1-\rho) \phi_{x} .
$$

W analogiczny sposób wygładzanie stóp procentowych możemy zaaplikować również do reguł w wariancie antycypacyjnym bądź adaptacyjnym.

W literaturze podkreśla się, że istotne statystycznie oceny parametru inercji stóp procentowych mogą jedynie odzwierciedlać autokorelację zakłóceń w modelu (Rudebush, 2002). Autokorelacja może z kolei wynikać z nieodpowiedniej specyfikacji równania Taylora (np. pominięcia ważnych zmiennych, przyjęcia założenia o liniowości badanej relacji) bądź być efektem długotrwałych szoków dotykających rynek finansowy. Zagadnienie to bada Castelnuovo (2003). W tym celu oszacował on parametry reguły Taylora opartej o pierwsze przyrosty. W przypadku, gdy oszacowana inercja stóp procentowych jest skutkiem autokorelacji, parametry modelu na przyrostach spełniają określone warunki poboczne.

Castelnuovo (2003) rozważał to zagadnienie dla różnych wariantów reguły Taylora, opartej o dane kwartalne dla Stanów Zjednoczonych. Przeprowadzony test wskazał, że wygładzanie stóp procentowych nie było efektem autokorelacji. Nowsze badanie tego samego autora (Castelnuovo, 2007) przynosi podobne rezultaty dla strefy euro, jednak pogłębiona analiza wyników prowadzi do wniosku, że istotną rolę odgrywają obydwa efekty, tj. zarówno wygładzanie stóp procentowych, jak i autokorelacja zakłóceń.

Z kolei Hsing (2005), w ślad za propozycją Mehra (1997), poza opóźnioną zmienną endogeniczną postanawia wprowadzić oczekiwania odnośnie do krótkookresowej stopy procentowej, aproksymowane przez opóźnione o jeden okres oprocentowanie 10-letnich papierów skarbowych. Okazuje się, że zmienna ta wyjaśnia krótkookresowe stopy procentowe w większym stopniu niż luka produkcyjna i stopa inflacji.

Smets i Wouters $(2003,2007)$ oraz Adolfson i in. (2007) skontruowali modele, w których specyfikacja dynamiczna reguły Taylora przedstawiała się następująco $^{15}$ :

$$
i_{t}=i_{0}^{*}+\rho i_{t-1}+\phi_{\pi}^{*}\left(\pi_{t}-\bar{\pi}\right)+\phi_{x}^{*} x_{t}+\phi_{\Delta \pi}^{*} \Delta\left(\pi_{t}-\bar{\pi}\right)+\phi_{\Delta \pi}^{*} \Delta x_{t}
$$

Reguła (2.7) stanowi rozszerzenie równania (2.6) o pierwsze przyrosty inflacji i luki. W takim podejściu zakłada się, że bank centralny reaguje inaczej na trwałą inflację i lukę produkcyjną, a inaczej na bieżące, krótkookresowe szoki wpływające na te zmienne. Ponadto jak wskazuje Grzęda Latocha (2005. s. 76), takie podejście pozwala uwzględnić nieliniowości w reakcji polityki pieniężnej ${ }^{16}$.

${ }^{15} \mathrm{~W}$ pracy Adolfson i in. (2007), dodatkowo występował realny kurs walutowy.

${ }^{16}$ Zagadnienie postaci funkcyjnej reguły Taylora omawiamy dalej. 


\section{Dodatkowe zmienne objaśniające}

Modyfikacje samej reguły dotyczą również zakresu zmiennych wchodzących w jej skład. W zasadzie nie ma wątpliwości co do dwóch podstawowych zmiennych ${ }^{17}$.

W literaturze pojawiło się kilka propozycji uwzględnienia kolejnych zmiennych objaśniających.

Ball (1999) rozpatrzył zachowanie adaptacyjnej reguły Taylora w teoretycznym modelu opisującym gospodarkę otwartą. Stwierdza on, że standardowe postacie funkcji reakcji banku centralnego implikują stosunkowo wysokie zmienności inflacji oraz luki produkcyjnej. Zaproponowana przez Balla postać reguł zakłada zastąpienie inflacji, tempem wzrostu cen „wyczyszczonym” z wpływu realnego kursu walutowego. Zastosowanie takiej zmiennej jest niemal równoważne $\mathrm{z}$ wprowadzeniem realnego kursu walutowego jako dodatkowego regresora. Svensson (2000) rozpatruje takie rozszerzenie reguły Taylora w ramach stylizowanego modelu nowokeynesistowskiego. Dochodzi do wniosku, że uwzględnienie kursu zmniejsza wariancję realnego kursu walutowego i luki produkcyjnej, w zamian za nieznaczny wzrost wariancji inflacji.

Wydaje się, że uwzględnianie kursu walutowego bądź innych charakterystyk gospodarki otwartej, nie zyskało popularności. Na gruncie teoretycznym Taylor (2001) wskazuje na możliwą przyczynę takiego stanu rzeczy. Argumentuje on, że (i) rozszerzenie reguły polityki pieniężnej o kurs walutowy nie poprawia znacząco skuteczności polityki pieniężnej oraz (ii) wynikające z reguł optymalnych długookresowe parametry określające reakcję stóp procentowych na zmianę kursu walutowego są niewielkie.

Dodajmy, że wyniki dotychczasowych badań empirycznych nie pozwalają jednoznacznie odpowiedzieć na pytanie, czy banki centralne reagują na zmiany kursu walutowego (por. np. Gerdesmeier, Roffia, 2003; Lubik, Schorfheide, 2007). Wydaje się, że kurs walutowy w większym stopniu określa uwarunkowania polityki pieniężnej w małych gospodarkach o znacznym stopniu otwartości ${ }^{18}$.

Wprowadzenie dodatkowych zmiennych może także wynikać ze specyfiki strategii polityki pieniężnej w danej gospodarce. Przykładowo, niemiecki Bundesbank prowadził politykę opierając się na celu pośrednim w postaci kontroli wzrostu podaży pieniądza (por. np. Zawadzka, 1997, s. 43). Z tego powodu w niemal wszystkich empirycznych analizach reguły Taylora w Niemczech wprowadza się

${ }^{17}$ Spotyka się jednak prace podkreślające zalety prowadzenia polityki pieniężnej według reguły korzystającej wyłącznie z inflacji. Wallusch (2013, s. 65 i n.) nazywa je „regułami prostymi” i analizuje obok różnych wariantów reguły Taylora.

${ }^{18} \mathrm{~W}$ tym kontekście warto wspomnieć, że średnia ważona z odchylenia krótkookresowej stopy procentowej i efektywnego kursu walutowego, znana jako MCI (Monetary Condition Index) stanowi alternatywną (wobec samej stopy procentowej) miarę restrykcyjności polityki pieniężnej (zob. Kokoszczyński, 2004, s. 181-183). 
odchylenie tempa wzrostu agregatu pieniężnego od tempa docelowego (np. Clarida, Gali, Gertler, 1998). Obecnie analiza takiego odchylenia stanowi ważną część strategii polityki Europejskiego Banku Centralnego (tzw. drugi filar) ${ }^{19}$. Dlatego jest ona często włączana do szacunków reguły Taylora dla strefy euro (np. Castelnuovo, 2007; Castro, 2011) ${ }^{20}$, a niekiedy także innych krajów - np. Japonii (Clarida, Gali, Gertler, 1998) czy Stanów Zjednoczonych (Swamy, Tavlas, Chang, 2005). W ostatnich latach toczy się szeroka dyskusja na temat słuszności reakcji banku centralnego na nadmierny wzrost ceny aktywów finansowych oraz nieruchomości, sugerujący możliwość istnienia tzw. baniek spekulacyjnych. Istotą bańki spekulacyjnej jest wzrost cen niebędący efektem wpływu czynników fundamentalnych, posiadający cechy samorealizującej się prognozy (zob. np. Blanchard, Fischer, 1993, s. 221-223).

W takim przypadku za polityką banku centralnego, uwzględniającą możliwość istnienia bańki spekulacyjnej, a więc zmierzającą do „przekłucia bańki” poprzez zaostrzenie polityki pieniężnej, przemawiają (Blinder, 2006; Rybiński, 2007, s. 318-326): (i) instytucjonalne zobowiązanie banku centralnego do dbałości o stabilność systemu finansowego, (ii) stosunkowo łatwe, ,intuicyjne" wykrycie bańki spekulacyjnej o dużych rozmiarach, (iii) negatywne skutki bańki spekulacyjnej w postaci niepożądanej redystrybucji zasobów, a w skrajnym przypadku kryzysu makroekonomicznego, (iv) zdolność banku centralnego do podjęcia działań, które jednocześnie „przekłują” bańkę, nie powodując przy tym znaczącego spadku aktywności gospodarczej ani wzrostu inflacji.

Z kolei przeciwnicy reagowania na wzrost cen aktywów wskazują na: (i) ogromne trudności z odpowiednio wczesnym rozróżnieniem „,fundamentalnego” wzrostu cen od bańki spekulacyjnej, (ii) brak odpowiedzialności banku centralnego za błędne decyzje prywatnych podmiotów gospodarczych, (iii) brak instrumentów banku centralnego umożliwiających bezpośrednią kontrolę cen aktywów.

Po doświadczeniach związanych z kryzysem finansowym rozpoczętym w 2008 roku, coraz większą popularność (zarówno w badaniach naukowych, jak i praktyce banków centralnych) zyskała idea polityki makroostrożnościowej (zob. np. Galati, Moessner, 2012). Zgodnie z nią polityka pieniężna powinna koncentrować się nie tylko na zapewnieniu stabilności cen, ale także brać pod uwagę zagrożenia dla (stosunkowo niejednoznacznie zdefiniowanej) stabilności systemu finansowego. W szczególności jednym z celów polityki makroostrożnościowej jest zapobieganie nierównowagom poprzez zmiany stóp procentowych oraz innych instrumentów, jakimi dysponuje bank centralny.

${ }^{19}$ Również Bank Szwajcarii wskazuje na dużą rolę dynamiki kredytów, aczkolwiek nie są nam znane analizy reguły Taylora dla Szwajcarii wykorzystujące dynamikę agregatów pieniężnych (bądź czynników je kreujących).

${ }^{20}$ Dodajmy, że zmienna ta nie ma w większości analiz istotnego wpływu na kształtowanie się stóp procentowych. Wynika z tego wniosek, że EBC w niewielkim stopniu analizuje te informacje, koncentrując się na realizacji celu inflacyjnego. 
Naturalną konsekwencją jest więc możliwość uwzględnienia miary sytuacji na rynku aktywów finansowych jako dodatkowej zmiennej w regule Taylora.

Hayford i Malliaris (2004), analizując to zagadnienie dla Stanów Zjednoczonych w okresie sprawowania urzędu szefa Systemu Rezerwy Federalnej przez Alana Greenspana, stwierdzają słaby negatywny wpływ współczynnika cena/zysk $(P / E)$ na stopy procentowe. Wobec spodziewanego dodatniego związku rezultat ten jest zaskakujący. Wedle komentarza autorów oznacza to, że Alan Greenspan uwierzył w korzystny wpływ innowacji pojawiających się w drugiej połowie lat 90. XX wieku (określanych wówczas mianem „,nowej ekonomii”) na długookresowy wzrost wydajności pracy, bądź też zaniechano interwencji ze względu na jej wysokie koszty makroekonomiczne. Cecchetti i Li (2005) potwierdzają zgodny z przesłankami teoretycznymi wpływ dźwigni finansowej sektora bankowego na stopy procentowe w regule Taylora dla Stanów Zjednoczonych, lecz nie potwierdzają go dla Niemiec i Japonii.

Kolejną propozycją jest dodanie spreadów na rynku pieniężnym (różnicy pomiędzy stopą procentową Bid i Ask), co stanowi dobry wyprzedzający wskaźnik koniunktury (Gerlach-Kristen 2000, cyt. za: Castelnuovo, 2003). Sądzimy również, że zmienna ta może oddawać szeroko rozumiane ryzyko występujące na rynku finansowym.

$\mathrm{Na}$ rynku finansowym występuje bardzo wiele instrumentów. Dlatego badawcze chcący uwzględnić ceny aktywów mają trudność z wyborem jednej zmiennej, co skłania wielu autorów do wprowadzenia w regule Taylora syntetycznych miar koniunktury na rynkach finansowych. Jedną z takich miar, zwaną indeksem uwarunkowań rynku finansowego (Financial Condition Index), stosują np. Castro (2011) oraz Milas i Naraidoo (2012). W przypadku obu prac indeks ten zdefiniowano jako średnią ważoną: realnego efektywnego kursu walutowego, cen nieruchomości (w relacji do poziomu cen towarów i usług), indeksów giełdowych (w relacji do poziomu cen towarów i usług) oraz różnic stóp procentowych o różnej zapadalności. Wynik pracy Castro (2011), w której analizowano regułę Europejskiego Banku Centralnego, Banku Anglii oraz systemu rezerwy federalnej, potwierdza istotny wpływ indeksu uwarunkowań rynku finansowego jedynie w przypadku Europejskiego Banku Centralnego.

Dodajmy na marginesie, że często badanie reakcji polityki pieniężnej na wzrost cen aktywów finansowych jest przeprowadzane na podstawie danych o częstotliwości dziennej, co wyklucza zastosowanie równania opartego na koncepcji reguły Taylora (np. Bohl, Siklos, Werner, 2007).

\section{Sposób pomiaru inflacji i luki produkcyjnej}

Z punktu widzenia prac empirycznych ważnym problemem jest sposób pomiaru zmiennych objaśniających - inflacji i luki produkcyjnej. W tym rozdziale 
analizujemy sposób pomiaru tych zmiennych wyłącznie pod kątem ich użycia w empirycznych badaniach reguły Taylora (ogólne zagadnienia związane z pomiarem inflacji i luki produkcyjnej zostały już opisane w rozdz. 1).

Wydaje się, że zastosowana miara inflacji powinna być tożsama $\mathrm{z}$ tą, za pomocą której skwantyfikowano cel inflacyjny. Jak już wspomniano, w przypadku większości krajów stanowi ją indeks cen towarów i usług konsumpcyjnych (CPI).

W literaturze toczy się dyskusja, czy bank centralny powinien reagować na ruchy inflacji wynikające z szoków podażowych. Z jednej strony taka reakcja nie powinna nastąpić, ze względu na to, że szoki te leżą poza kontrolą banku centralnego, a większość z nich ma charakter przejściowy. Jednakże zwiększenie inflacji prowadzić będzie do osłabienia wiarygodności banku centralnego, a ponadto może przełożyć się na wzrost oczekiwań inflacyjnych, co spowoduje tzw. efekty drugiej rundy (zob. np. Svensson, 1999; Wojtyna, 2004, s. 161). Dyskusja o tym, czy bank centralny powinien reagować na szoki podażowe jest bardzo rozległa i nie będziemy jej szczegółowo opisywać, jednak należy dopuścić możliwość zróżnicowania siły reakcji banku centralnego na zmiany cen, np. w zależności od źródła pochodzenia i siły „szoków”. W takim wypadku pojawia się możliwość uwzględnienia inflacji bazowej obok inflacji CPI, lub wręcz zamiast niej, w regule Taylora. Miara inflacji bazowej, uwzględnia bowiem jedynie wzrost cen nie wynikający z działania krótkookresowych szoków, na które polityka pieniężna nie ma wpływu (zob. też rozdz. 1).

Dużo więcej kontrowersji budzi sposób pomiaru luki produkcyjnej (problem ten opisujemy w rozdz. 1). W regule Taylora jest to raczej wybór badacza, jako że banki centralne w oficjalnych dokumentach nie prezentują w jaki sposób liczona jest luka produkcyjna, a także czy zmienna ta jest w ogóle wykorzystywana $\mathrm{w}$ procesie decyzyjnym.

Obszerne porównania wyników estymacji równań reguły Taylora dla Polski przeprowadziła Michałek (2009). Pod uwagę wzięto miary luki oparte na filtrze Hodricka-Prescotta i deterministycznym trendzie, bazując na szeregu PKB odsezonowanym za pomocą procedury Tramo/Seats bądź zmiennych zerojedynkowych. Wyniki tego badania wskazują, że wybór metody szacowania luki wpływa na szacunki parametrów reguły Taylora - w przeciwieństwie do metody odsezonowania PKB (w wariantach $\mathrm{z}$ wygładzaniem stóp procentowych ${ }^{21} \mathrm{i}$ dla PKB w cenach stałych). Ponieważ szacunki Michałek (2009) nie są w pełni porównywalne $\mathrm{z}$ estymacjami, które wykonamy w rozdziale 3 (autorka wykorzystała stopę referencyjną NBP oraz nie uwzględniła corocznych zmian w poziomie celu inflacyjnego w latach 1999-2003), przeprowadzimy własne analizy wrażliwości na zmianę sposobu pomiaru luki produkcyjnej.

Oddzielnym problemem (dotyczącym głównie wariantu backward looking) jest ,aktualność” danych wykorzystywanych przez bank centralny. Orphanides

\footnotetext{
${ }^{21}$ Autorka nazywa ten mechanizm „wewnętrzną strukturą procesu”.
} 
(2001) zauważył, że prawidłowe odwzorowanie procesu decyzyjnego banku centralnego jest możliwe, gdy korzysta się wyłącznie z danych dostępnych bankowi centralnemu w momencie podejmowania decyzji (tzw. dane real-time).

Najświeższe dane statystyczne udostępniane są jako wstępne, po czym zwykle po upływie kilku miesięcy są nieznacznie korygowane. Głębsze rozbieżności pomiędzy danymi real-time oraz ex-post (zrewidowanymi, najbardziej aktualnymi) wynikają z rewizji danych wstecz. Dlatego, poza uwzględnieniem stosownych opóźnień, w każdym okresie powinno się wykorzystywać osobne szeregi zmiennych objaśniających. W badaniu Orphanidesa (2001) różnice dotyczyły głównie szeregu $\mathrm{PKB}^{22}$. Co więcej, różnice pomiędzy szeregami real-time oraz ex -post pogłębiły się, jeśli porównywać oszacowane na ich podstawie szeregi luki produkcyjnej. Podobne rezultaty osiągnięto w kolejnych badaniach opartych na szeregach real-time (np. Orhanides, 2003; Reade, 2006; Baranowski, 2008c), choć różnice pomiędzy tymi dwoma podejściami do oszacowania luki nie zawsze miały wpływ na oszacowania parametrów reguły Taylora. W szczególności, w naszym badaniu dla Polski nie potwierdzono istotnej reakcji polityki pieniężnej na lukę produkcyjną, niezależnie od tego czy wykorzystano szereg typu real-time, czy dane uwzględniające rewizje.

$\mathrm{Z}$ drugiej strony warto pamiętać, że odwzorowanie szeregu real-time jest bardzo pracochłonne, wymaga bowiem zgromadzenia danych o wszystkich rewizjach (w tym dat ich ogłoszenia). Ze względu na brak oficjalnych informacji odnośnie do szczegółów obliczania luki przez bank centralny oraz danych na temat ewentualnych korekt eksperckich i tak trudno byłoby precyzyjnie odwzorować szereg luki produkcyjnej, którym dysponują władze banku centralnego. Na rzecz wykorzystania szeregu danych ex-post świadczą także wyniki otrzymane przez Aruoba (2008). Stwierdza on, że rewizje danych makroekonomicznych mają statystycznie niezerową wartość oczekiwaną, a do tego są w znacznym stopniu przewidywalne. W takim przypadku bank centralny może (choćby nieświadomie) prognozować rewizje i wówczas szereg ex-post może stanowić wystarczająco dobre przybliżenie luki produkcyjnej „widzianej oczami banku centralnego”23.

\section{Postać funkcyjna równania}

Oryginalna praca Taylora (1993), podobnie jak większość późniejszych szacunków reguły Taylora, zakłada liniową postać równania. Teoretycznym

${ }^{22} \mathrm{Z}$ tą samą sytuacją mamy do czynienia w przypadku danych dla gospodarki Polski - wskaźnik CPI nie podlega rewizji, z wyjątkiem danych za styczeń każdego roku, kiedy GUS publikuje jedynie wstępny szacunek tego wskaźnika (ostateczne dane są publikowane miesiąc później).

${ }^{23}$ Zbliżony pogląd wyraża też Croushore (2011, s. 94), wskazując że ,jeśli decydenci polityki pieniężnej wiedzą, że nastąpi rewizja, wówczas mogą optymalnie odfiltrować z danych sygnał [tj. ostateczne dane nt. PKB - przyp. P.B.], tak że rewizje nie będą istotnie wpływać na kształt polityki pieniężnej”. 
wsparciem takiej postaci jest rozwiązanie problemu minimalizacji funkcji straty banku centralnego wyrażonej przy pomocy kwadratowej funkcji odchyleń inflacji od poziomu docelowego i luki produkcyjnej (podobne zagadnienie, choć w nieco innym kontekście, stawiano w pracach poświęconych niespójności polityki pieniężnej - zob. Załącznik 1.1). W takim przypadku warunek konieczny maksymalizacji tej funkcji wyraża się w postaci liniowej reguły Taylora. Blinder (1997) podkreśla jednak, że „naukowcy zajmujący się makroekonomią często przyjmują kwadratową funkcję strat ze względu na wygodę prowadzenia obliczeń, nie przejmując się przy tym rzeczywistymi implikacjami takiego podejścia". Potwierdza to, że liniowość reguły Taylora jest wyłącznie założeniem, które może podlegać empirycznej weryfikacji.

Szczególnie interesujący przypadek nieliniowości dotyczy asymetrii reakcji polityki pieniężnej na zmienne określające sytuację gospodarczą. Banki centralne niekiedy oficjalnie deklarują taką asymetrię, np. poprzez ogłoszenie w strategii tzw. oportunistycznego podejścia do dezinflacji. Strategia taka zakłada dużo słabszą reakcję na procesy, które spowodują obniżenie inflacji poniżej celu, a tym samym ułatwią osiągnięcie długookresowego celu inflacyjnego (zob. np. Blinder, 1997; Grabowski, 2000).

Narodowy Bank Polski publicznie deklarował stosowanie takiej polityki obniżania inflacji. Na przykład, cel inflacyjny na rok 2001 został ustalony na poziomie 6-8\%, przy czym w przypadku wystąpienia korzystnych szoków podażowych „prowadzących do osiągnięcia inflacji niższej od dolnej granicy celu inflacyjnego, Rada Polityki Pieniężnej kształtować będzie stopień restrykcyjności [...] mając na uwadze realizację celu średniookresowego [tj. 4\% - przyp. P.B.]" (Założenia..., 2000, s. 6-70).

Pewne sugestie asymetrii polityki monetarnej znajdują się także w strategii polityki pieniężnej Europejskiego Banku Centralnego, która precyzuje cel finalny jako utrzymanie inflacji HICP (Harmonised Index of Consumer Prices) w strefie euro „poniżej 2\%” (The Monetary..., 2004). Takie sformułowanie jednoznacznie określa jedynie górną granicę celu inflacyjnego, co sprawia, że reakcja na spadek inflacji poniżej celu może być słabsza.

Dodajmy także własną hipotezę uzasadniającą nieliniową, lecz symetryczną reakcję polityki pieniężnej na odchylenia zmiennych od wartości docelowych. W sytuacji, gdy takie odchylenia są znaczące, może to oznaczać że dotychczasowa reakcja banku centralnego była zbyt słaba, należy zatem zwiększyć siłę oddziaływania. Funkcja spełniająca te wymagania musiałaby być wklęsła dla małych wartości argumentu oraz wypukła dla wysokich.

Rozstrzygnięcie, czy reguła Taylora ma postać liniową czy nieliniową, było przedmiotem wielu opracowań. Martin i Milas (2004) próbują oszacować nieliniową wersję reguły Taylora za pomocą zmodyfikowanego modelu wygładzo- 
nego przejścia ${ }^{24}$. Na jego podstawie stwierdzają zmiany wielkości parametrów, gdy inflacja przekroczy progi odpowiednio: 1,4\% i 2,6\%. Badanie to przynosi dwa kolejne ciekawe rezultaty. Po pierwsze, zmiany inflacji pomiędzy tymi dwoma progami nie wywołują zmiany stóp procentowych. Po drugie, „odległości” powyższych progów od celu inflacyjnego $(2,5 \%)$ są istotnie różne, co zdaniem autorów potwierdza asymetrię reakcji polityki pieniężnej (silniejsza reakcja, gdy inflacja znajduje się powyżej celu).

Kim, Osborn i Sensier (2005) badają nieliniowość dla Systemu Rezerwy Federalnej (SRF) za pomocą semiparametrycznego estymatora zaproponowanego przez Hamiltona. W podejściu tym model posiada dwie części: liniową (parametryczną) oraz nieliniową (nieparametryczną). Dzięki takiemu podejściu nieliniowa część równania Taylora nie wymaga przyjęcia założenia o konkretnej postaci funkcyjnej badanej relacji. W badaniu tym potwierdzono nieliniowość jedynie dla okresu przed drugą połową 1979 roku, tj. przed objęciem stanowiska prezesa SRF przez Paula Volckera.

Taylor i Davradakis (2006) z kolei badali nieliniowości polityki pieniężnej Banku Anglii za pomocą modelu progowego (threshold model) ${ }^{25}$. Wyróżniono dwa reżimy: o niskiej i wysokiej inflacji (odpowiednio: poniżej i powyżej 3,1\% rocznie). Z badania wynika, że różnice oszacowań w poszczególnych reżimach są znaczne. W pierwszym reżimie inflacja nie jest statystycznie istotna, co więcej zachowanie stóp procentowych odpowiada $\mathrm{w}$ zasadzie procesowi błądzenia losowego (random walk). W drugim reżimie stopę procentową dobrze opisuje natomiast reguła Taylora $\mathrm{z}$ wygładzaniem stóp procentowych. Taka reakcja może również w dużej mierze wynikać z zerowej granicy stóp procentowych (braku możliwości obniżenia nominalnej stopy procentowej poniżej zera $)^{26}$. Adam i Billi (2005) stwierdzają, że sposobem na uniknięcie zerowej granicy stóp procentowych mogą być bardziej zdecydowane (w porównaniu z sytuacją, gdy nie ma takiego zagrożenia, np. nominalne stopy procentowe są stosunkowo wysokie) obniżki stóp procentowych. To z kolei implikuje konieczność nieliniowej reakcji banku centralnego.

Znane nam badania asymetrii dla Polski (Baranowski, 2008b; Sznajderska, 2012), choć przeprowadzone na podstawie różnych specyfikacji dynamicznych reguły (odpowiednio warianty: adaptacyjny i antycypacyjny) oraz na podstawie danych o różnej częstotliwości, zgodnie potwierdzają asymetrię reakcji polityki

\footnotetext{
${ }^{24}$ Istotą tych modeli jest odejście od założenia o stałych wartościach parametrów. Zamiast tego przyjmuje się, że są stałe w poszczególnych przedziałach wartości zmiennej odpowiadającej danemu parametrowi, przy czym przejście pomiędzy poszczególnymi reżimami jest płynne (w literaturze polskiej szerszy opis przedstawia np. Welfe, 2009, s. 182-185).

${ }^{25} \mathrm{~W}$ podejściu tym stosuje się składaną funkcję liniową, przez co parametry są przedziałami stałe. Granice tych przedziałów podlegają estymacji.

${ }^{26}$ Szerzej problem zerowej granicy nominalnych stóp procentowych omawiają np.: Kokoszczyński (2004, s. 124-125), Wojtyna (2004a, s. 110 i n.) oraz Yates (2004).
} 
pieniężnej na inflację. Uzyskane wyniki wskazywały, że silniejsza reakcja występowała przy wysokiej inflacji (co wskazywało na kierunek asymetrii zgodny ze strategią oportunistycznej dezinflacji). W pracy (2008b) weryfikowaliśmy ponadto hipotezę o nieliniowym, lecz symetrycznym wpływie inflacji (tak jak np. w pracy Adam i Billi, 2005). Hipoteza ta nie uzyskała potwierdzenia.

Porównanie liniowych i nieliniowych modeli ekonometrycznych (nie tylko opisujących stopy procentowe, jak reguła Taylora) jest utrudnione, bowiem każdy model bardziej ogólny ma lepsze dopasowanie w obrębie próby, na której estymowano parametry (in-sample). Stąd też w większości prac testuje się zasadność restrykcji pozwalających uprościć model nieliniowy do modelu liniowego. Alternatywnym podejściem jest porównanie liniowych i nieliniowych postaci reguły Taylora, pod kątem błędów prognoz otrzymywanych ,poza próbą" wykorzystaną do estymacji (out-of-sample). Stosując tę metodologię, Qin i Enders (2008) dochodzą do wniosku, że ekstrapolacja poza próbę zarówno liniowych, jak i nieliniowych reguł Taylora przynosi gorsze wyniki niż w przypadku prostych modeli autoregresyjnych (rzędu drugiego oraz rzędu pierwszego na przyrostach). Nieco lepszą jakość równań reguły Taylora otrzymali Milas i Naraidoo (2012). Stwierdzili oni, że, z wyjątkiem najkrótszych horyzontów prognozy ( $\mathrm{tj}$. jeden i dwa miesiące naprzód), niektóre postacie nieliniowej reguły Taylora mają lepsze własności prognostyczne niż modele autoregresyjne. Sądzimy, że dalsze badania pozwolą rozstrzygnąć wątpliwości co do możliwości prognozowania rynkowych stóp procentowych przez modele o konstrukcji wywodzącej się z reguły Taylora.

\section{Stabilność parametrów}

Innym interesującym zagadnieniem poruszanym przez empiryczne szacunki reguły Taylora jest stabilność w czasie jej parametrów. Najczęściej weryfikowano hipotezę o skokowej zmianie parametrów reguły Taylora pomiędzy dwiema lub więcej podpróbami, np. określonymi przez kadencje organów decyzyjnych banku centralnego.

Przykładowo, Judd i Rudebush (1998) oraz Clarida i in. (2000) potwierdzili zmiany parametrów strukturalnych na skutek zmiany prezesa Banku Rezerwy Federalnej. We wcześniejszym opracowaniu (Baranowski, 2008b) analizowaliśmy m.in. wpływ zmiany kadencji Rady Polityki Pieniężnej na parametry adaptacyjnej reguły Taylora. Rezultaty wskazywały, iż parametry reguły Taylora dla gospodarki polskiej były stałe w czasie (także w przypadku zastosowania luki produkcyjnej opartej o szeregi real-time).

Z kolei Castelnuovo (2007) badał w tym samym kontekście wpływ wprowadzenia trzeciego etapu Unii Gospodarczej i Walutowej (po 1 stycznia 1999). Otrzymane rezultaty nie potwierdzały zmiany strukturalnej w owym czasie. 
Natomiast w przypadku, gdy z góry nie możemy określić w jakim okresie nastąpiły zmiany parametrów, możemy zastosować modele przełącznikowe (o zmiennym reżimie, regime-switching). Sims i Zha (2006), opierając się na bayesowskim modelu VAR o zmiennym reżimie, zakwestionowali tezę o niestabilności parametrów w funkcji reakcji Banku Rezerwy Federalnej. Ich badanie wskazywało, że istotnym zmianom podlegała raczej wariancja szoków, a nie parametry strukturalne.

Możemy wskazać na inne przyczyny zmiany parametrów reguł Taylora, jak choćby ewolucję poglądów członków ciał decyzyjnych. W przypadku, gdy taka ewolucja jest stopniowa, możemy zastosować bardziej ogólne podejście, w którym parametry mogą w każdym okresie przyjmować różne wartości (time-varying parameters model $)^{27}$. Zapisana $\mathrm{w}$ ten sposób statyczna reguła Taylora przedstawiałaby się następująco:

$$
i_{t}=i_{0}+\phi_{\pi, t}\left(\pi_{t}-\bar{\pi}\right)+\phi_{x, t} x_{t}
$$

gdzie:

$\phi_{\pi, t}, \phi_{x, t}-$ parametry strukturalne (w okresie $\left.t\right)$.

Boivin (2006) zastosował takie podejście do estymacji antycypacyjnej reguły Taylora opartej na danych real-time. Jego wyniki pozwoliły stwierdzić, że siła reakcji stóp procentowych podlegała nieregularnym zmianom do połowy lat 80 . $\mathrm{XX}$ wieku, po czym ustabilizowała się. Bardziej rozbudowane metodologicznie odmiany tego podejścia stosowali także: Cogley i Sargent (2005), Swamy, Tavlas i Chang (2005) oraz Canova i Gambetti (2009). W wymienionych badaniach stwierdzono dużą zmienność w czasie parametrów reguły Taylora. Podejście takie jest bardzo interesujące, jednak sama metoda estymacji wymaga bardzo licznej próby, którą obecnie nie dysponujemy.

Dodajmy również, że zmiana reżimu może być także analizowana na podstawie modeli zmiennych dyskretnych. Gerlach (2011) stosując logitowy model zmiennej uporządkowanej, stwierdził, że Europejski Bank Centralny zmienił sposób prowadzenia polityki pieniężnej po rozpoczęciu kryzysu finansowego w 2008 roku.

\section{Zastosowania reguły Taylora}

Zaprezentowane $\mathrm{w}$ niniejszym rozdziale różne postacie reguły Taylora są często wykorzystywane w ekonomii.

${ }^{27} \mathrm{~W}$ tym celu stosuje się model zapisany w postaci przestrzeni stanów, gdzie równania stanu opisują parametry wyznaczone za pomocą procesu błądzenia losowego. 
Po pierwsze, może ona służyć opisowi i ocenie polityki pieniężnej. Ciekawych wniosków dostarcza interpretacja parametrów $\phi_{\pi}$ i $\phi_{x}$ opisujących siłę reakcji stopy procentowej na odchylenia luki produkcyjnej i inflacji od wartości pożądanych. Interpretację ekonomiczną możemy nadać także wyrazowi wolnemu $i_{0}$, który określa nominalną stopę procentową w równowadze, w ujęciu realnym (tj. $i_{0}-\bar{\pi}$ ) nazywaną tzw. naturalną stopą procentową (zob. np. Brzoza-Brzezina, 2003; Woodford, 2003, s. 286-290).

Dodajmy na marginesie, że większość opracowań dotyczących reguły Taylora przyjmuje założenie o stałej naturalnej stopie procentowej (zob. Brzoza-Brzezina, 2003). Istnieje oczywiście wiele szacunków naturalnej stopy procentowej, które odchodzą od tego założenia. Najczęściej jednak koncepcja reguły Taylora nie jest wykorzystywana bezpośrednio do wyznaczenia przebiegu tej kategorii. Wykorzystuje się tu szereg podejść metodologicznych jak np. filtry statystyczne, modele przestrzeni stanów, modele SVAR (Structural Vector Autoregression) czy zmodyfikowaną koncepcję oczekiwań krzywej dochodowości (Crespo-Cuaresma, Gnan, 2007; Brzoza-Brzezina, 2003; Laubach, Williams, 2003).

Drugim celem jest prognozowanie zmian oficjalnych stóp procentowych. W tym celu wystarczyłoby podstawić do reguły Taylora wartości luki produkcyjnej oraz inflacji. Pewnym problemem może być brak danych za bieżący okres, dlatego najczęściej wykorzystuje się tutaj warianty backward looking z odpowiednio długimi opóźnieniami zmiennych objaśniających (opóźnienia te powinny być równe co najmniej horyzontowi prognozy, w przeciwnym wypadku należałoby uprzednio wyprognozować wartości zmiennych objaśniających). Modele oparte na regule Taylora mogą stanowić narzędzie umożliwiające prognozowanie rynkowych stóp procentowych lub oficjalnych stóp procentowych banku centralnego. Prognozy oficjalnych stóp banku centralnego (a właściwie ich zmian) są znacznie częściej spotykane i, jak już wspomniano, korzysta się z modeli opisujących zmienne dyskretne.

Po trzecie, równanie Taylora jest również wykorzystywane jako fragment modelu gospodarki narodowej. Na szczególną uwagę zasługują modele DSGE oparte naparadygmacie nowej ekonomii keynesistowskiej (zaprezentowane w rozdz. 4). W tej klasy modelach reguła polityki pieniężnej stanowi „domknięcie” pełnego modelu składającego się w najprostszej wersji z: równania inflacji - nowokeynesistowskiej krzywej Phillipsa oraz równania luki produkcyjnej - dynamicznej krzywej IS ${ }^{28}$.

W modelach tych reguła Taylora analizowana jest głównie pod kątem analizy mechanizmu transmisji szoków. Takie analizy przeprowadzimy w dalszej

${ }^{28}$ Szczegółową prezentację tego typu modeli czytelnik znajdzie np. w: Gali (2008, rozdz. 3.3), Woodford, (2003, s. 245-246), Walsh (2010, s. 244-247) lub Romer (2011, rozdz. 7). Prezentację tej klasy modeli przedstawiamy na początku rozdz. 4, natomiast wyprowadzenia dodatkowo w: Baranowski i in. (2012). 
części pracy (rozdz. 4), gdzie skoncentrujemy się na reakcji na szok polityki pieniężnej, a tym samym odpowiemy na drugie pytanie badawcze. Wśród innych zagadnień, w których wykorzystuje się regułę Taylora w ramach modeli DSGE możemy wymienić:

a) badania stabilności modelu - rozumianej jako jednoznaczność rozwiązania racjonalnych oczekiwań (determinacy); omówienie tej kwestii można znaleźć w pracach: Woodford (2003, 252-261) oraz Lubik i Marzo (2007), zaś w literaturze polskiej szeroko opisuje ją Wallusch $(2011,2013)^{29}$;

b) poszukiwania horyzontu czasowego i parametrów reguł, które zapewniają minimalizację funkcji strat banku centralnego w nieskończonym horyzoncie czasowym (tzw. reguły optymalne); obszerny przegląd metod i zastosowań znajduje się w monografii Giannoni i Woodforda (2002);

c) symulacji zachowania gospodarki w warunkach zerowej granicy nominalnych stóp procentowych (zero-bound, zob. np. Adam, Billi, 2005),

d) wyboru stopy procentowej o zapadalności zapewniającej największą efektywność polityki pieniężnej (np. Gerlach-Kristen, Rudolf, 2010).

\section{Podsumowanie}

W rozdziale przedstawiono najważniejsze aspekty badań nad regułą zaproponowaną przez J.B. Taylora (1993), wiążącą krótkookresową nominalną stopę procentową z luką produkcyjną oraz odchyleniem inflacji od celu.

W badaniach empirycznych objaśnia się krótkookresową stopę procentową rynku pieniężnego bądź jedną ze stóp procentowych ustalaną przez bank centralny. W drugim przypadku badacze wykorzystują najczęściej modele logitowe lub probitowe dla zmiennych uporządkowanych.

Kolejnym ważnym zagadnieniem, zarówno w analizach teoretycznych, jak i badaniach empirycznych, jest specyfikacja dynamiczna reguły (statyczna, adaptacyjna - backward looking lub antycypacyjna - forward looking). Niezależnie od opóźnień lub wyprzedzeń zmiennych egzogenicznych, reguła Taylora może być rozszerzona o wygładzanie stóp procentowych (interest rate smoothing). Uwzględnienie wygładzania stóp procentowych wydaje się obecnie standardem, zarówno w pracach z zakresu teorii ekonomii, jak i badaniach empirycznych.

Modyfikacje reguły Taylora odnoszą się również do liczby zmiennych objaśniających. Poza odchyleniem inflacji od celu oraz luką produkcyjną spotyka się dodatkowo szereg zmiennych (realny kurs walutowy, tempo wzrostu agregatów pieniężnych oraz charakterystyki rynków finansowych). Mimo to wydaje się, że w tym zakresie osiągnięto konsensus, polegający na uwzględnieniu jedynie dwóch podstawowych zmiennych: inflacji oraz luki produkcyjnej. Pozostałe

${ }^{29} \mathrm{~W}$ pracach Walluscha stosuje się thumaczenie „określoność równowagi”. 
zmienne spotyka się sporadycznie, a badania empiryczne nie potwierdzają jednoznacznie ich znaczenia w kształtowaniu się stóp procentowych.

W wielu przypadkach można podejrzewać, że polityka pieniężna nie reaguje liniowo na odchylenie inflacji od celu czy lukę produkcyjną. Taki sposób kształtowania decyzji (często także asymetryczny) polityki pieniężnej jest niekiedy nawet oficjalnie deklarowany przez banki centralne. Zagadnienie to jest interesujące $\mathrm{w}$ analizach reguły Taylora jako pojedynczego równania. Zastosowanie nieliniowej wersji reguły Taylora w analizach modeli DSGE jest utrudnione, gdyż uwzględnienie $\mathrm{w}$ takich modelach zależności nieliniowych bardzo komplikuje rozwiązania racjonalnych oczekiwań.

Inną ciekawą hipotezą, często weryfikowaną za pomocą omawianej reguły jest stabilność parametrów reguły Taylora. Najczęściej sprawdzano, czy nastąpiła zmiana parametrów funkcji reakcji po zmianie kadencji organów decyzyjnych banku centralnego. Nowsze badania nie ograniczają się jednak do takich analiz, w efekcie czego otrzymuje się oszacowanie przebiegu wartości parametrów strukturalnych.

Reguła Taylora może być wykorzystana jako narzędzie do opisu polityki pieniężnej, prognozowania stóp procentowych bądź stanowić ważny element teoretycznych lub empirycznych modeli gospodarki narodowej (szczególnie klasy DSGE). 



\section{REGULA TAYLORA DLA POLSKI \\ - ADAPTACYJNA, BIEŻĄCA I ANTYCYPACYJNA}

\section{Wprowadzenie}

Celem podjętym w rozdziale jest oszacowanie parametrów reguły Taylora dla Polski. Rozważania obejmą trzy warianty specyfikacji dynamicznej: adaptacyjny (backward looking), bieżący (current looking) oraz antycypacyjny (forward looking). Dzięki temu nasze analizy obejmą wszystkie trzy możliwe przypadki, w których władze monetarne reagują: na przeszłe, bieżące oraz przyszłe (oczekiwane) wartości zmiennych objaśniających. W przypadku reguły antycypacyjnej uwzględnimy dodatkowo podejście zaproponowane przez Bernanke i Boivina (2003), pozwalające odzwierciedlić reakcję banku centralnego na wiele zmiennych (data-rich environment) potencjalnie kształtujących przyszłą inflację.

Otrzymane szacunki reguły Taylora pozwolą ocenić reakcję polityki pieniężnej na inflację i lukę produkcyjną, a następnie w rozdziale 4 posłużą do budowy modelu DSGE i analizy wpływu szoku polityki pieniężnej na lukę produkcyjną i inflację.

\section{Regula Taylora dla Polski - analizowane warianty}

W opracowaniu zweryfikujemy, czy stosunkowo prosta reguła polityki pieniężnej, jaką jest reguła Taylora, znajduje potwierdzenie w danych dla gospodarki Polski. Już w tym miejscu zaznaczamy, że szacowane równania traktujemy przede wszystkim jako „dobre przybliżenie” funkcji reakcji polityki pieniężnej. W praktyce bowiem polityka pieniężna jest prowadzona raczej w sposób ekspercki niż „mechaniczne” podążanie za z góry ustaloną stosunkowo prostą regułą. W szczególności bierze się pod uwagę znacznie szerszy zbiór zmiennych niż inflacja i luka produkcyjna, a do tego siła reakcji może ulegać zmianie. Problem reakcji na wiele zmiennych można uwzględnić na kilka sposobów - w pracy badamy podejście z wykorzystaniem syntetycznych wskaźników uzyskiwanych za pomocą analizy czynnikowej. Natomiast stabilność parametrów reguły Taylora ocenimy na podstawie szacunków opierają się na zmieniającej się próbie z rozszerzającym się oknem estymacji (recursive sample).

Jak już wspominano $\mathrm{w}$ poprzednim rozdziale, zdecydowana większość badań empirycznych nad regułą Taylora uwzględnia wygładzanie stóp 
procentowych ${ }^{1}$. Dlatego też nasze szacunki reguły Taylora dla Polski rozpoczniemy od weryfikacji hipotezy $\mathrm{H} 2$ o wygładzaniu mechanizmu stóp procentowych.

Rozpatrzymy więc trzy rodzaje reguł różniących się horyzontem reakcji na inflację i lukę produkcyjną. Z wyjątkiem badań Walluscha (2013, rozdz. 5) - w których jednak nie uwzględniono wygładzania stóp procentowych, te trzy warianty reguły Taylora dla Polski nie były estymowane w jednej pracy. Ponadto w wyjściowych postaciach reguł adaptacyjnej i bieżącej poszerzamy regułę o przyrosty luki i inflacji, przez co uwzględniamy postulat modelowania „od ogółu do szczegółu”. Jak już wspomniano, jednoczesne uwzględnienie przyrostu i poziomu danej zmiennej może także być przybliżeniem jej nieliniowego wpływu. Natomiast w regule antycypacyjnej, gdzie stosujemy estymację za pomocą uogólnionej metody momentów, ograniczamy się do wariantów z mniejszą liczbą parametrów. Ograniczenia nakładane na liczbę parametrów wynikają z trudności ze znalezieniem odpowiedniej ilości „dobrych” zmiennych instrumentalnych (przypomnijmy z rozdz.1, że ich liczba musi być większa od liczby szacowanych parametrów). Stąd też w tym ostatnim wariancie wyjściowa specyfikacja reguły nie zawiera przyrostów inflacji i luki.

Pierwszym rozpatrzonym wariantem jest reguła adaptacyjna (backward looking) o postaci:

$$
i_{t}=i_{0}+\rho i_{t-1}+\phi_{\pi} \pi_{t-k}+\phi_{x} x_{t-l}+\phi_{\Delta \pi} \Delta \pi_{t-k}+\phi_{\Delta x} \Delta x_{t-l}+\varepsilon_{t}
$$

Kolejnym wariantem jest reguła bieżąca (current looking), która przedstawia się następująco:

$$
i_{t}=i_{0}+\rho i_{t-1}+\phi_{\pi} \pi_{t}+\phi_{x} x_{t}+\phi_{\Delta \pi} \Delta \pi_{t}+\phi_{\Delta x} \Delta x_{t}+\varepsilon_{t}
$$

Wreszcie ostatnim wariantem jest reguła antycypacyjna (forward looking), uwzględniająca postulat „wyprzedzającej reakcji” na inflację i lukę produkcyjną:

$$
i_{t}=i_{0}+\rho i_{t-1}+\phi_{\pi} \boldsymbol{E}_{t}\left(\pi_{t+m}\right)+\phi_{\pi} \boldsymbol{E}_{t}\left(\pi_{t+n}\right)_{t}+\varepsilon_{t}
$$

Uwaga: na podstawie parametrów powyższych równań możemy obliczyć długookresową reakcję na inflację i lukę, daną wzorami odpowiednio: $\phi_{\pi} /(1-\rho)$ oraz $\phi_{x} /(1-\rho)$.

Osobnym przypadkiem rozpatrzonym w opracowaniu jest wariant reguły antycypacyjnej, w którym bank centralny - pośrednio - reaguje na dużą liczbę

${ }^{1}$ W okresie styczeń 1999 - styczeń 2013 Rada Polityki Pieniężnej podjęła 32 decyzje o zmianie stopy referencyjnej 0,25 p. proc., wobec 57 wszystkich decyzji o zmianie tej stopy. 
zmiennych potencjalnie kształtujących inflację. Wariant ten posiada interesującą motywację ekonomiczną, a także nieco inne podejście metodologiczne. Zagadnienie to omówimy poniżej.

\section{Podejście data-rich $\mathrm{w}$ analizie reguł polityki pieniężnej}

Strategia bezpośredniego celu inflacyjnego, stosowana m.in. przez Narodowy Bank Polski, zakłada, że cel nadrzędny banku centralnego jakim jest utrzymanie niskiej inflacji jest wyrażony ilościowo i podany do publicznej wiadomości, a jego realizacja nie wymaga użycia celów pośrednich ${ }^{2}$. Dlatego też bank centralny $\mathrm{w}$ procesie podejmowania decyzji bierze pod uwagę dużą liczbę zmiennych mających wpływ na kształtowanie się inflacji (zob. np.: Bernanke i in., 2001, s. 22). Przykładowo, w Polsce, poza wskaźnikiem cen towarów i usług konsumpcyjnych, za pomocą którego wyrażony jest cel inflacyjny, analizie podlegają takie zmienne jak: ceny producenta, PKB oraz jego komponenty, dochody i wydatki sektora finansów publicznych, charakterystyki rynku pracy, kurs złotego względem głównych walut, zmienne z rynku finansowego, agregaty pieniężne czy saldo bilansu obrotów bieżących (zob. Raport o inflacji, listopad 2012).

Taka praktyka, w połączeniu z postulatem reakcji wyprzedzającej, wskazuje, że analizy polityki pieniężnej powinny odzwierciedlać reakcję banku centralnego na szeroki wachlarz zmiennych mających potencjalne znaczenie prognostyczne.

Standardowym podejściem do formalno-modelowej metody uzyskania zmiennych syntetyzujących informacje pochodzące z licznego zbioru danych są modele czynnikowe (zob. Stock i Watson, 2006; w literaturze polskojęzycznej: Szafrański, 2013). Jednocześnie wiele prac poświęconych prognozowaniu sygnalizuje, że tak otrzymane zmienne mają dużą zdolność prognostycznąa ${ }^{3}$ Oczywiście mamy świadomość, że reakcja władz monetarnych na tak wiele zmiennych ma charakter ekspercki i wynika raczej z dyskusji i ścierania się poglądów członków ciał decyzyjnych ${ }^{4}$ niż z formalnej analizy czynnikowej. Przypuszczamy jednak, że wprowadzenie tak skonstruowanej syntetycznej zmiennej może przybliżyć zastosowany model do rzeczywistości.

Idea zaprezentowana powyżej została wykorzystana po raz pierwszy przez Bernankego i Boivina (2003), którzy w charakterze inflacji oczekiwanej

${ }^{2}$ Obszerny przegląd tej strategii przedstawia np. Svensson (2011). Szerszy opis dla Polski przedstawiają np. Krajewski i Baranowski (2006), Musielak-Linkowska (2007).

${ }^{3}$ Na przykład Kotłowski (2008) oraz Baranowski, Leszczyńska i Szafrański (2010) wskazują, iż zmienne skonstruowane za pomocą analizy czynnikowej pozwalają dobrze prognozować inflację w Polsce. Analogiczne wnioski dotyczące dynamiki PKB przedstawia praca Łupińskiego (2012).

${ }^{4}$ Rada Polityki Pieniężnej w połowie 2007 roku rozpoczęła publikację dokumentów opisujących dyskusję na posiedzeniach (Opisy dyskusji Rady Polityki Pieniężnej na posiedzeniach decyzyjnych - tzw. minutes). 
wykorzystali prognozy z dynamicznego modelu czynnikowego, następująco definiując oczekiwanias:

$$
\mathbf{E}_{\mathbf{t}}\left(\pi_{t+1}\right)=\varphi_{1} f_{1, t}+\varphi_{2} f_{2, t}+\ldots+\varphi_{R} f_{R, t}
$$

gdzie:

$f_{1, t}, f_{2, t}, \ldots, f_{R, t}-$ wspólne czynniki (kolejno, według malejącego udziału wariancji objaśnionej), $\varphi_{1}, \varphi_{2}, \ldots, \varphi_{R}-$ parametry strukturalne.

Zbliżone podejście zaproponowali Favero i in. (2005), którzy oszacowali parametry reguły Taylora za pomocą uogólnionej metody momentów ${ }^{6}$, stosując wspólne czynniki w charakterze zmiennych instrumentalnych. W rezultacie oczekiwania inflacyjne zostały zdefiniowane jako kombinacja liniowa bieżących wartości wspólnych czynników, podobnie jak w podejściu Bernankego i Boivina (2003). Jedyna różnica tkwi w oszacowaniach parametrów $\varphi_{1}, \varphi_{2}, \ldots, \varphi_{R}$, przy czym zaletą estymacji przy pomocy uogólnionej metody momentów jest zgodna i efektywna estymacja w warunkach autokorelacji lub heteroskedastyczności składników losowych równania (4). Dodatkowo, jak wskazują Kapetanios i Marcellino (2010), użycie w charakterze instrumentu wspólnego czynnika poprawia efektywność estymatora. Co więcej, dobre własności estymatora są zachowane nawet $\mathrm{w}$ przypadku, gdy instrumenty są słabo skorelowane $\mathrm{z}$ endogenicznymi zmiennymi objaśniającymi (opisany w rozdz. 1 problem ,słabych instrumentów”) lub gdy istnieją zmienne wchodzące w skład wspólnych czynników, dla których udział wariancji wyjaśnionej przez wspólne czynniki spada wraz z dodaniem kolejnych zmiennych do tego czynnika (problem „słabej struktury wspólnych czynników").

\section{Wykorzystane dane statystyczne}

W badaniu wykorzystamy dane źródłowe:

$i_{t}$ - stopa procentowa WIBOR 1M (średnia kwartalna),

$\pi_{t}$ - stopa inflacji, mierzona indeksem cen towarów i usług konsumpcyjnych (analogiczny kwartał roku poprzedniego $=100$ ),

$y_{t}-$ produkt krajowy brutto (w cenach stałych).

${ }^{5} \mathrm{~W}$ pracy Bernankego i Boivina (2003) wykorzystano $R=3$ wspólne czynniki. Dodatkowo w równaniu dopuszczono występowanie opóźnień, których rząd dobierano rekursywnie korzystając z kryterium Schwarza.

${ }^{6}$ Wyjaśnienie takiego ujęcia oczekiwań w kontekście antycypacyjnej reguły Taylora znajduje się w następnej części niniejszego rozdziału. 
Ze względu na dostępność szeregu stopy procentowej, ,,wspólna próba” obejmuje okres od I kw. 1997 do III kw. 2012. Do estymacji równań reguły Taylora wykorzystamy jednak próbę krótszą, tj. od I kw. 1999, co odpowiada początkowi stosowania strategii bezpośredniego celu inflacyjnego w Polsce.

Szeregi źródłowe poddajemy następującym przekształceniom.

Po pierwsze - ze względu na zmienny w czasie cel inflacyjny oraz występowanie w próbie okresu dezinflacji, w regule Taylora stosujemy odchylenie inflacji od oficjalnego celu inflacyjnego Narodowego Banku Polskiego tj. $\tilde{\pi}_{t}=\pi_{t}-\pi_{t}^{c e l}$.

Po drugie - lukę produkcyjną obliczamy jako procentowe odchylenie PKB od deterministycznego trendu wykładniczego ${ }^{7}$, tj. wyznaczając produkcję potencjalną na podstawie modelu:

$$
\ln \left(y_{t}\right)=\alpha_{0}+\alpha_{1 t}+\varepsilon_{t}
$$

Szeregi te wykorzystamy także do estymacji pozostałych równań modelu DSGE (w rozdz. 4), z tym że wówczas będziemy mogli skorzystać z pełnej próby.

Na wykresach 1-4 przedstawiamy przebiegi szeregów czasowych wykorzystanych do estymacji.

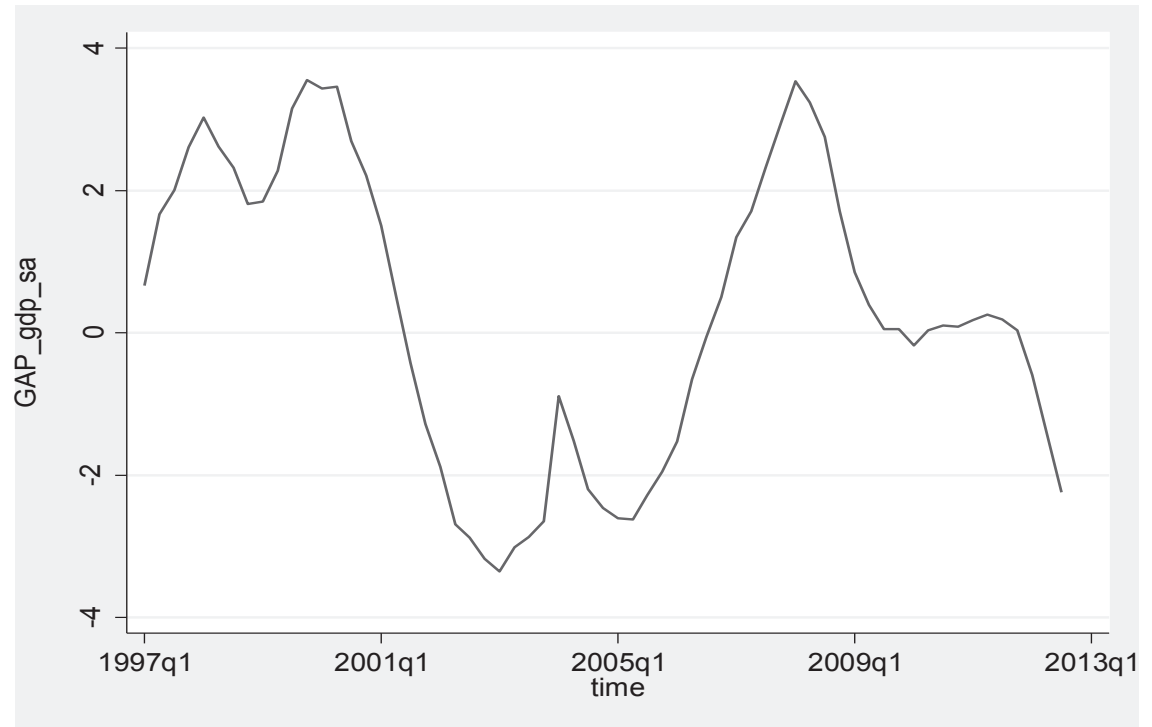

Wykres 1. Luka produkcyjna $\left(x_{t}\right)$

Źródło: obliczenia własne (dotyczy wszystkich wykresów w rozdz. 3)

${ }^{7} \mathrm{~W}$ celu zbadania wrażliwości wyników estymacji reguły Taylora na sposób pomiaru luki, stosujemy dodatkowo warianty z luką szacowaną przy pomocy filtru Hodricka-Prescotta (zob. Załącznik 3.4). 


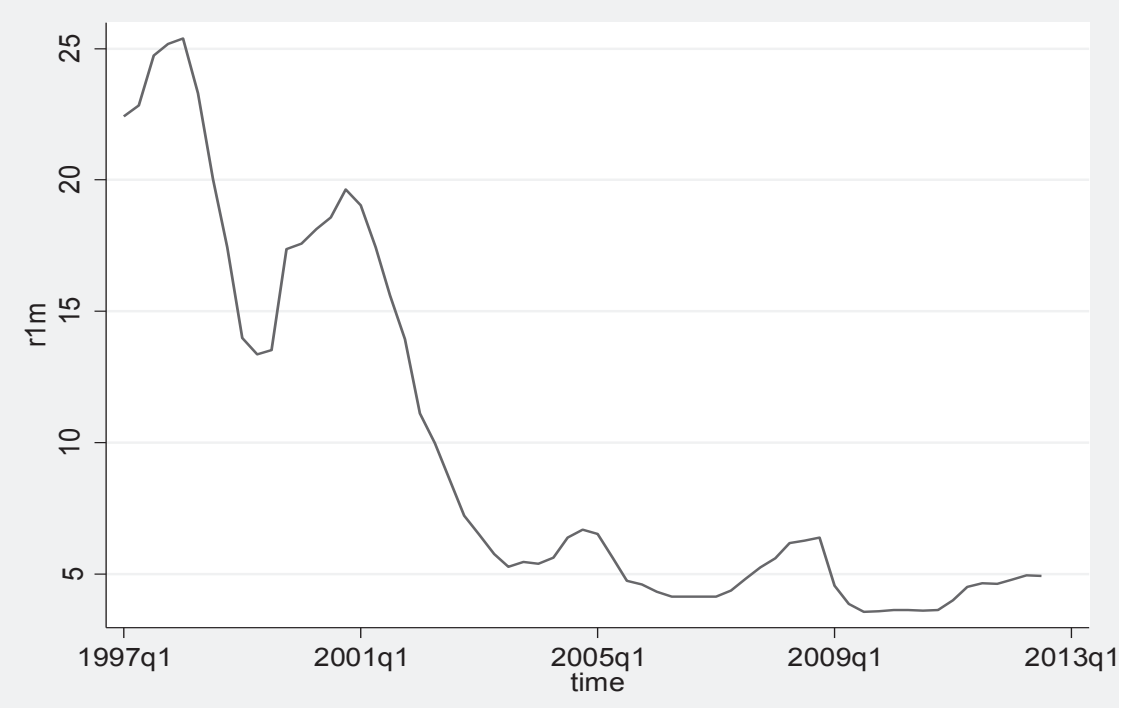

Wykres 2. Stopa procentowa WIBOR 1M $\left(i_{t}\right)$

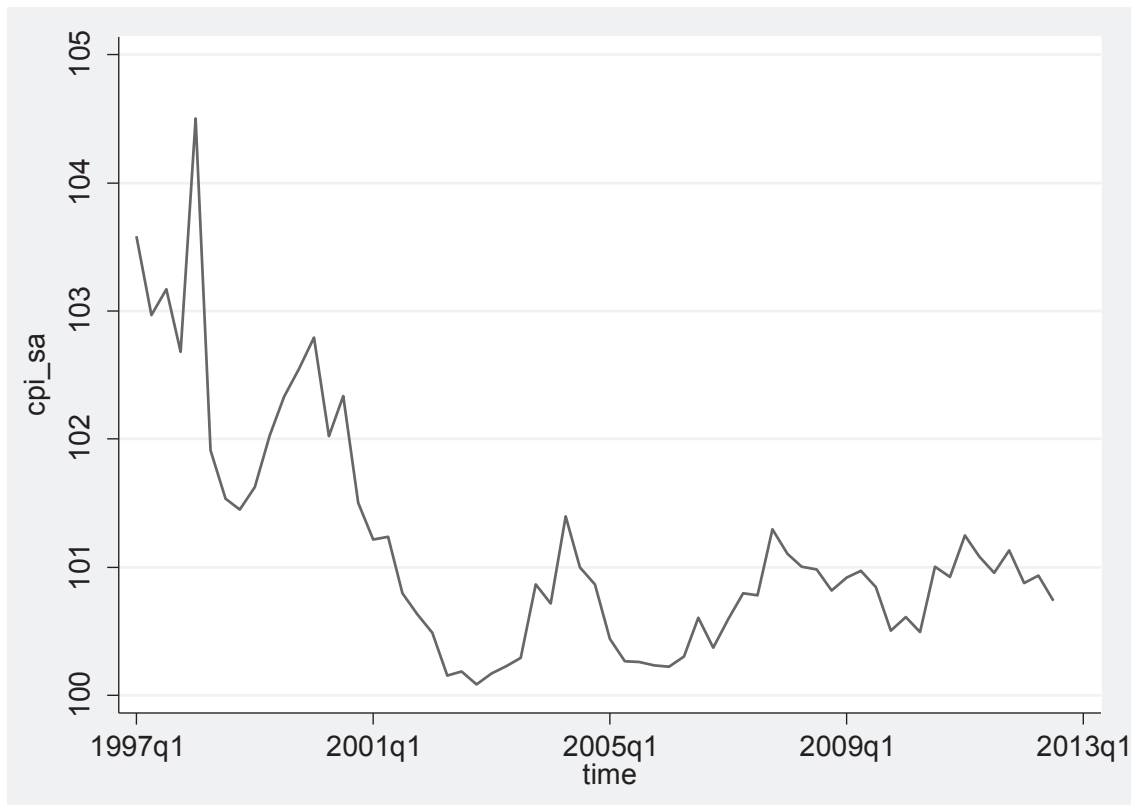

Wykres 3. Inflacja CPI kw/kw (odsezonowana) $\left(\pi_{t}^{k w}\right)$ 


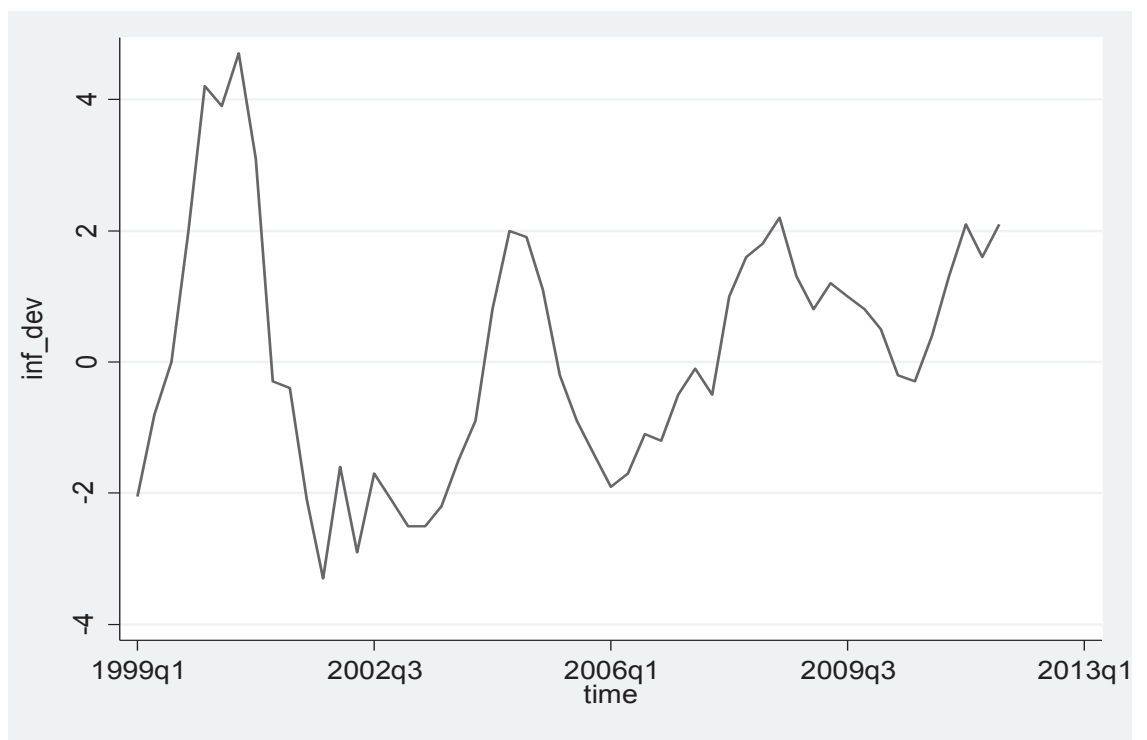

Wykres 4. Odchylenie inflacji CPI r/r od celu $\left(\tilde{\pi}_{t}\right)$

W ramach wstępnej analizy danych badamy stacjonarność zmiennych. W tab. 3.1 przedstawiamy statystyki testów pierwiastka jednostkowego: Dickeya -Fullera (DF) oraz rozszerzonego testu Dickeya-Fullera (ADF) i testu stacjonarności Kwiatkowskiego-Phillipsa-Schmidta-Shina (KPSS) dla szeregów wykorzystanych do estymacji poszczególnych wariantów reguły Taylora. Natomiast w tab. 3.2 przedstawiamy wyniki dla szeregów, które wykorzystamy w rozdz. 4.

Tabela 3.1. Wyniki testów pierwiastka jednostkowego i stacjonarności (dane wykorzystane do estymacji reguły Taylora, próba od I kw. 1999)

\begin{tabular}{|c|c|c|c|c|c|}
\hline \multirow{2}{*}{ Zmienna } & DF & \multicolumn{3}{|c|}{ ADF } & KPSS \\
\cline { 2 - 6 } & \multicolumn{5}{|c|}{ Liczba opóźnień } \\
\cline { 2 - 6 } & nie dotyczy & 1 & Auto & 4 & Auto \\
\hline$\tilde{\pi}_{t}$ & $-2,17$ & $-2,80^{*}$ & $-2,47(\mathrm{p}=4)^{*}$ & $-2,47^{*}$ & 0,18 \\
\hline$x_{t}$ & $-0,92$ & $-1,87$ & $-1,87(\mathrm{p}=1)$ & $-1,71$ & 0,17 \\
\hline$i_{t}$ & $-1,84$ & $-1,62$ & $-1,62(\mathrm{p}=1)$ & $-1,63$ & $0,62^{* *}$ \\
\hline
\end{tabular}

Objaśnienia:

Auto oznacza dobór opóźnienia (w zakresie od 0 do 5 kwartałów) według kryterium informacyjne Schwarza (ADF) bądź N-W (KPSS).

$*, * *, * * *$ oznaczają odpowiednio: odrzucenie hipotezy zerowej na 10-procentowym, 5-procentowym, 1-procentowym poziomie istotności.

Źródło: obliczenia własne. 
Tabela 3.2. Wyniki testów pierwiastka jednostkowego i stacjonarności (dane wykorzystane w rozdz. 4, próba od I kw. 1997)

\begin{tabular}{|c|c|c|c|c|c|}
\hline \multirow{2}{*}{ Zmienna } & DF & \multicolumn{3}{|c|}{ ADF } & KPSS \\
\cline { 2 - 6 } & \multicolumn{5}{|c|}{ Liczba opóźnień } \\
\cline { 2 - 6 } & nie dotyczy & 1 & Auto & 4 & Auto \\
\hline$\pi_{t}^{k w}$ & $-2,99^{* *}$ & $-2,50$ & $-2,99^{* *}(\mathrm{p}=0)$ & $-4,94^{* * *}$ & $0,44^{*}$ \\
\hline$x_{t}$ & $-1,02$ & $-2,13$ & $-2,13(\mathrm{p}=1)$ & $-1,85$ & 0,23 \\
\hline$i_{t}$ & $-3,19^{* * *}$ & $-2,88^{* *}$ & $-2,88^{* *}(\mathrm{p}=1)$ & $-2,74^{*}$ & $0,77^{* * *}$ \\
\hline
\end{tabular}

Objaśnienia: jak do tab. 3.1.

Źródło: jak do tab. 3.1 .

Wyniki testów zawarte w tab. 3.1 i 3.2 pozwalają wyciągnąć następujące wnioski:

- w świetle większości przeprowadzonych testów odchylenie inflacji od celu jest stacjonarne;

- w przypadku stopy procentowej wyniki testów są zróżnicowane w zależności od długości wykorzystanej próby - w przypadku rozpoczynającej się od I kw. 1997 stwierdzamy stacjonarność na podstawie większości testów, zaś dla próby krótszej (od I kw. 1999) niemal wszystkie testy wskazują na niestacjonarność tego szeregu;

- większość testów wskazuje na niestacjonarność luki produkcyjnej, zarówno w przypadku próby sięgającej od I kw. 1999, jak i od I kw. 1997;

- inflacja w stosunku do poprzedniego kwartału (odsezonowana) jest stacjonarna w świetle większości przeprowadzonych testów odchylenie inflacji od celu.

Stoimy jednak na stanowisku, że wskazania powyższych testów należy interpretować bardzo ostrożnie.

Po pierwsze, ze względu na nie w pełni jednoznaczne wskazania zastosowanych testów (zwłaszcza jeśli chodzi o zmianę próby).

Po drugie, ze względu na ich bardzo małą moc w krótkich próbach. Phillips i Xiao (1998) wskazują, że w procesach silnie autoregresywnych (tj. o współczynniku autoregresji co najmniej 0,9) dla prób liczących 100 obserwacji moc testów nie przekracza $30 \%$. Co więcej, w świetle cytowanego badania dzieje się tak niezależnie od wyboru testu pierwiastka jednostkowego. Moc testów dodatkowo obniżać mogą: możliwa autokorelacja i obserwacje nietypowe lub zmiany strukturalnej (czyli szeroko rozumiana niepewność co do procesu generującego dane). 
Być może ze względu na nie najlepsze własności testów, problem stacjonarności polskiej inflacji oraz wielu innych szeregów makroekonomicznych nie został, jak się wydaje, definitywnie rozstrzygnięty empirycznie. Ograniczając się jedynie do badań kwartalnych szeregów inflacji w Polsce możemy wskazać dwie przykładowe prace: Wdowińskiego (2011), który stwierdza że inflacja CPI (liczona względem poprzedniego kwartału, po odsezonowaniu) jest stacjonarna oraz Grabka (2006), który wskazuje na niestacjonarność (zintegrowanie w stopniu pierwszym) inflacji CPI (liczonej względem analogicznego kwartału poprzedniego roku). Choć trudno formułować jakiekolwiek wnioski na podstawie porównania wyników dwu badań, to możemy zaryzykować tezę, iż rozbieżności te wynikają z tego, że szereg inflacji liczonej względem analogicznego roku z definicji posiada znacznie wyższą , uporczywość” (jest ona tożsamościowym złożeniem czterech poprzednich inflacji liczonej kw/kw, stąd sąsiadujące obserwacje inflacji $\mathrm{r} / \mathrm{r}$ posiadają dwie wspólne obserwacje inflacji kw/kw).

Poruszając kwestię pozastatystycznych argumentów na rzecz stacjonarności inflacji wygodnie jest założyć, że polityka pieniężna jest prowadzona w ramach strategii bezpośredniego celu inflacyjnego. W takim przypadku inflacja powinna być stacjonarna, a zwłaszcza jej odchylenie od celu. Po pierwsze, polityka banku centralnego stabilizuje inflację i zapewnia jej powrót do celu. Po drugie - w powrocie do celu pomaga również zakotwiczenie oczekiwań inflacyjnych wokół celu. Na przykład Halunga, Osborn i Sensier (2009) zauważają, że inflacja stała się stacjonarna po wdrożeniu strategii bezpośredniego celu inflacyjnego.

$\mathrm{Z}$ kolei luka produkcyjna stanowi krótkookresowe odchylenie PKB od długookresowego trendu, a zatem powinna być stacjonarna $\mathrm{z}$ definicji.

W dalszej części pracy, mimo wątpliwości, zmienne użyte do badania będziemy traktować jako stacjonarne. W takim przypadku wyniki będą w dużym stopniu warunkowe względem tego założenia.

\section{Wyniki estymacji - reguła adaptacyjna}

Pierwszym wariantem poddanym analizie empirycznej jest adaptacyjna reguła Taylora (3.1) (backward looking), tj. z wartościami inflacji oraz luki produkcyjnej opóźnionymi o jeden kwartał oraz wygładzaniem stóp procentowych.

$$
i_{t}=i_{0}+\rho i_{t-1}+\phi_{\pi} \tilde{\pi}_{t-1}+\phi_{x} x_{t-1}+\phi_{\Delta \pi} \Delta \tilde{\pi}_{t-1}+\phi_{\Delta x} \Delta x_{t-1}+\varepsilon_{t}
$$

Analizowano również inne warianty opóźnień reguły Taylora (aż do opóźnienia rzędu trzech kwartałów - wyniki te przedstawiamy w Załączniku 3.2). Spośród nich wybrano wariant o najkrótszych opóźnieniach (jeden kwartał dla inflacji i luki produkcyjnej, tj. $l=k=1$ ). W porównaniu do innych, jedynie wariant 
o opóźnieniu jednego kwartału dla inflacji i dwóch dla luki produkcyjnej, cechował się porównywalnym dopasowaniem. Ostatecznie wybrano regułę prostszą (tj. o krótszych opóźnieniach), która po oszacowaniu za pomocą MNK przedstawiała się następująco ${ }^{8}$ :

$$
\begin{aligned}
& i_{t}=-6,062+0,984 i_{t-1}+0,201 \tilde{\pi}_{t-1}+0,201 \Delta \tilde{\pi}_{t-1}+0,011 x_{t-1}+0,201 \Delta x_{t-1} \\
& (45,8) \quad(2,9) \quad(2,2) \quad(0,7) \\
& R^{2}=0,986 \quad L M(1)=3,5(p=6,1 \%) \quad L M(4)=5,4(p=24,7 \%)
\end{aligned}
$$

Znaki ocen parametrów są poprawne ekonomicznie (dodatnie). Nie występuje autokorelacja składników losowych, ale w przypadku jednej ze zmiennych (opóźniona luka produkcyjna) nie stwierdzamy istotnego statystycznie wpływu (przyjmując 5\% poziom istotności). Po usunięciu tej nieistotnej zmiennej i ponownym oszacowaniu parametrów otrzymujemy:

$$
\begin{aligned}
& i_{t}=-0,080+0,988 i_{t-1}+0,230 \tilde{\pi}_{t-1}+0,214 \Delta \tilde{\pi}_{t-1}+0,209 \Delta x_{t-1} \\
& (51,9) \\
& (4,4) \\
& (2,2) \\
& R^{2}=0,986 \\
& L M(1)=3,8(p=5,0 \%) \\
& L M(4)=6,3(p=18,2 \%)
\end{aligned}
$$

Otrzymane wyniki są poprawne ekonomicznie i statystycznie (wszystkie zmienne są istotnie statystycznie, nie występuje autokorelacja składników losowych $^{9}$, a stopień objaśnienia jest wysoki).

Wyniki możemy interpretować następująco:

- wzrost inflacji powyżej celu o $1 \mathrm{p}$. proc. spowoduje wzrost stopy procentowej łącznie o ok. 23 p. proc. (parametr długookresowy), z czego w następnym kwartale o ok. $0,23 \mathrm{p}$. proc. $\mathrm{z}$ tytułu wzrostu poziomu inflacji oraz jednorazowo o ok. 0,21 p. proc. z tytułu jej przyrostu (parametry krótkookresowe);

- wzrost luki produkcyjnej o $1 \mathrm{p}$. proc. spowoduje wzrost stopy procentowej w następnym kwartale jednorazowo o ok. 0,21 p. proc. (parametr krótkookresowy związany z przyrostem luki produkcyjnej);

- występuje bardzo silne (ok. 99\%) wygładzanie stóp procentowych.

Mimo że wyniki są formalnie poprawne, wydaje się, że otrzymana wartość długookresowej reakcji polityki pieniężnej jest trudna do interpretacji. Przy tak bliskim jedności parametrze wygładzania stóp procentowych reakcja ta jest bardzo rozłożona w czasie. Oczywiście trudno zakładać, że inflacja będzie trwale

\footnotetext{
${ }^{8}$ Pod oszacowaniami statystyki $t$-Studenta. LM(k) oznacza statystykę testu Breuscha-Pagana na występowanie autokorelacji rzędu k.

${ }^{9}$ Zauważmy jednak, że wartość statystyki autokorelacji 1 rzędu jest „na granicy” stwierdzenia autokorelacji (przyjmując standardowy 5-procentowy poziom istotności).
} 
wyższa od celu przez okres co najmniej kilku lat. Mając to na uwadze, przedstawimy interpretację przy bardziej realistycznym założeniu, że wzrost inflacji powyżej celu utrzyma się przez kilka kwartałów. Przykładowo, łączna reakcji stóp procentowych na podtrzymany wzrost inflacji o 1 p. proc. powyżej celu wynosi (pomijamy reakcję krótkookresową): $+1,34$ p. proc. w ciągu 6 kwartałów oraz $+1,76$ p. proc. w ciągu 8 kwartałów.

\section{Wyniki estymacji - regula bieżąca}

Drugim wariantem poddanym analizie empirycznej jest reguła Taylora z bieżącymi wartościami inflacji i luki produkcyjnej oraz wygładzaniem stóp procentowych (tj. równanie (3.2)).

$$
\begin{gathered}
i_{t}=6,016+0,972 i_{t-1}+0,279 \tilde{\pi}_{t}+0,002 \Delta \tilde{\pi}_{t}+0,019 x_{t}+0,123 \Delta x_{t} \\
(41,3) \quad(3,6) \quad(0,0) \quad(1,1) \quad(4,6) \\
R^{2}=0,986 \quad L M(1)=0,7(p=41,5 \%) \quad L M(4)=1,5(p=82,0 \%)
\end{gathered}
$$

Znaki ocen parametrów są poprawne ekonomicznie (dodatnie). Nie występuje autokorelacja składników losowych, ale w przypadku dwu zmiennych (luka produkcyjna i przyrost inflacji) nie stwierdzamy istotnego statystycznie wpływu (przyjmując 5-procentowy poziom istotności). Po usunięciu kolejno zmiennych nieistotnych otrzymano następującą postać równania:

$$
\begin{gathered}
i_{t}=0,019+0,965 i_{t-1}+0,370 \tilde{\pi}_{t}+0,152 \Delta x_{t} \\
(41,3) \quad(6,3) \quad(2,9) \\
R^{2}=0,979 \quad L M(1)=0,2(p=64,2 \%) \quad L M(4)=4,4(p=36,1 \%)
\end{gathered}
$$

Otrzymane wyniki są poprawne ekonomicznie i statystycznie (wszystkie zmienne są istotne statystycznie, nie występuje autokorelacja składników losowych a stopień objaśnienia jest wysoki).

Wyniki możemy interpretować następująco:

- wzrost inflacji powyżej celu o 1 p. proc. spowoduje wzrost stopy procentowej łącznie o ok. 10 p. proc. (parametr długookresowy), z czego w bieżącym kwartale o ok. 0,37 p. proc. (parametr krótkookresowy),

- wzrost luki produkcyjnej o $1 \mathrm{p}$. proc. spowoduje wzrost stopy procentowej jednorazowo o ok. $0,14 \mathrm{p}$. proc. (parametr krótkookresowy związany z przyrostem luki),

- występuje silne (ok. 96\%) wygładzanie stóp procentowych. 
Podobnie jak dla reguły adaptacyjnej, otrzymana ocena parametru wygładzania stóp procentowych jest wysoka. Dlatego też policzyliśmy łączną reakcję stóp procentowych na podtrzymany wzrost inflacji o $1 \mathrm{p}$. proc. powyżej celu wynosi (z pominięciem reakcji krótkookresowej): $+2,03$ p. proc. w ciągu 6 kwartałów oraz $+2,62$ p. proc. w ciągu 8 kwartałów.

\section{Wyniki estymacji - regula antycypacyjna}

W niniejszej części zweryfikujemy regułę Taylora z reakcją na oczekiwaną inflację i lukę produkcyjną oraz wygładzaniem stóp procentowych (tj. równanie (3.3)). Przy takiej postaci specyfikacji dynamicznej należy określić horyzont oczekiwań, na który następuje reakcja banku centralnego. Narodowy Bank Polski nie przedstawia oficjalnego stanowiska $\mathrm{w}$ tej kwestii ${ }^{10}$. Możemy jednak wskazać teoretyczne przesłanki wyboru horyzontu oczekiwań w funkcji reakcji banku centralnego. Po pierwsze - przypomnijmy (z rozdz. 2), że wyprzedzająca reakcja wynika przede wszystkim $\mathrm{z}$ opóźnienia $\mathrm{w}$ mechanizmie transmisji polityki pieniężnej. Jeśli zatem bank centralny chciałby skuteczniej kontrolować gospodarkę, wówczas horyzont reakcji powinien być równy opóźnieniu w mechanizmie transmisji (co do którego również istnieją rozbieżności w badaniach empirycznych). $Z$ drugiej jednak strony bank centralny może reagować z krótszym horyzontem oczekiwań niż wynikałoby to z opóźnienia w transmisji, np. ze względu na znaczne błędy oczekiwań (prognoz) dla dłuższych horyzontów.

Problem ten rozstrzygnęliśmy empirycznie. Porównaliśmy wyniki otrzymane dla równania z różnymi horyzontami oczekiwań (od 1 do 3 kwartałów - zob. Załącznik 3.3) pod kątem dopasowania i statystyki testu Hansena. W ten sposób uznaliśmy za najlepsze warianty reguł antycypacyjnych: z reakcją na inflację i lukę oczekiwaną w horyzoncie 1 kwartału oraz na inflację oczekiwaną w horyzoncie jednego i lukę oczekiwaną w horyzoncie dwóch kwartałów. Przyjęto pierwszy, prostszy wariant ${ }^{11}, \mathrm{w}$ rezultacie specyfikacja przedstawiała się następująco:

$$
i_{t}=i_{0}+\rho i_{t-1}+\phi_{\pi} \boldsymbol{E}_{t}\left(\pi_{t+1}\right)+\phi_{\pi} \boldsymbol{E}_{t}\left(\pi_{t+1}\right)+\varepsilon_{t}
$$

Stosując estymację GMM z wielokrotną aktualizacją macierzy wag z „tradycyjnym" zestawem zmiennych instrumentalnych (opóźnione o jeden kwartał:

${ }^{10}$ Jak już zresztą wspomniano na wstępie, podobną powściągliwość zachowują przedstawiciele banków centralnych zachowują w większości szczegółów związanych z czynnikami systematycznie kształtującymi stopy procentowe.

${ }^{11}$ Jednak w obu wariantach luka produkcyjna nie wpływała istotnie na stopę procentową. Usunięcie tej nieistotnej zmiennej prowadziło do tego samego końcowego wariantu reguły. 
zmienne objaśniające, wskaźnik cen producenta ${ }^{12}$ i średni kurs złotego względem euro) otrzymano następujące wyniki ${ }^{13}$ :

$$
\begin{gathered}
i_{t}=0,038+0,960 i_{t-1}+0,424 \boldsymbol{E}_{t}\left(\tilde{\pi}_{t+1}\right)+0,001 \boldsymbol{E}_{t}\left(x_{t+1}\right) \\
(58,1) \quad(5,0) \\
R^{2}=0,982 \\
J=1,4(p=50,0 \%)
\end{gathered}
$$

Zmienne instrumentalne: $\pi_{t-1}, x_{t-1}, p^{i} i_{t-1}^{s a}, \Delta e u r p l n_{t-1}^{s a}$.

Otrzymane wyniki są poprawne ekonomicznie i statystycznie - z wyjątkiem mało precyzyjnego oszacowania parametru związanego z luką produkcyjną. Po usunięciu tej zmiennej z równania otrzymano następujące wyniki:

$$
\begin{gathered}
i_{t}=0,125+0,960 i_{t-1}+0,424 E_{t}\left(\tilde{\pi}_{t+1}\right) \\
(60,4) \quad(8,3) \\
R^{2}=0,982 \quad J=1,6(p=66,2 \%) \quad K=15,2(p=1,9 \%)
\end{gathered}
$$

Zmienne instrumentalne: jak w poprzednim równaniu.

Wyniki należy ocenić jako poprawne ekonomicznie (dodatni znak parametru przy inflacji). Zmienne objaśniające są istotne statystycznie, zaś instrumenty poprawnie dobrane: wartość statystyki testu $J$ (Hansena) nie daje podstaw do odrzucenia hipotezy zerowej mówiącej, iż przyjęte warunki ortogonalności są spełnione, a na podstawie testu Kleibergena i Paap stwierdzamy silny wpływ instrumentów na endogeniczne zmienne objaśniające.

Wyniki możemy interpretować następująco:

- wzrost inflacji powyżej celu o 1 p. proc. spowoduje wzrost stopy procentowej łącznie o ok. 11 p. proc. (parametr długookresowy), z czego w bieżącym kwartale o ok. 0,42 p. proc. (parametr krótkookresowy),

- łączna zmiana stopy procy procentowej na podtrzymany, w horyzoncie: 6 i 8 kwartałów, wzrost inflacji o 1 p. proc. wynosi odpowiednio: $+2,30$ p. proc. $\mathrm{i}+2,95$ p. proc,

- występuje silne (ok. 96\%) wygładzanie stóp procentowych.

${ }^{12}$ Szereg cen produkcji sprzedanej przemysłu w ujęciu kwartał w stosunku do kwartału poprzedniego, odsezonowany za pomocą procedury Tramo/Seats.

${ }^{13}$ Pod oszacowaniami statystyki $t$-Studenta, obliczone na podstawie błędów szacunku parametrów odpornych na heteroskedastyczność i autokorelację (tzw. estymator HAC). $J$ i $K-P$ oznaczają statystyki odpowiednio: testu J (Hansena) i testu Kleibergena-Paap (opis tych testów przedstawiono w rozdz. 1). Obok statystyk testowych, w nawiasach podano empiryczny poziom istotności. $\mathrm{R}^{2}$ podane dla analogicznych równań estymowanych dwustopniową GMM. 
Stosując w charakterze zmiennych instrumentalnych dodatkowo wspólne czynniki z dużego zbioru danych (tzw. podejście data-rich) otrzymano następujące wyniki ${ }^{14}$ :

$$
\begin{gathered}
i_{t}=0,039+0,962 i_{t-1}+0,423 \boldsymbol{E}_{t}\left(\tilde{\pi}_{t+1}\right)+0,009 \boldsymbol{E}_{t}\left(x_{t+1}\right) \\
(42,8) \quad(3,0) \\
R^{2}=0,979 \quad(0,5)
\end{gathered}
$$

Zmienne instrumentalne: opóźnione zmienne objaśniające z reguły Taylora (tj. $\tilde{\pi}_{t+1}, x_{t+1}$ ) oraz wspólne czynniki: $f 2_{t}, f 2_{t-1}, f 3_{t}$.

Po usunięciu z równania nieistotnej statystycznie luki produkcyjnej:

$$
\begin{gathered}
i_{t}=0,105+0,962 i_{t-1}+0,426 \boldsymbol{E}_{t}\left(\tilde{\pi}_{t+1}\right) \\
(41,2) \quad(7,7) \\
R^{2}=0,978 \quad J=2,1(p=55,8 \%) \quad K-P=12,3(p=5,6 \%)
\end{gathered}
$$

Zmienne instrumentalne: jak w poprzednim równaniu.

Z porównania tych wyników z wynikami podejścia data-rich, możemy wyciągnąc dwa interesujące wnioski. Po pierwsze - w obu podejściach otrzymano zbliżone wyniki: luka produkcyjna nie wpływa istotnie na stopy procentowe, również wartości ocen parametrów są bardzo zbliżone. Po drugie - w świetle wskazań testów Hansena i Kleibergena-Paap, wydaje się, że zastosowanie wspólnych czynników w charakterze zmiennych instrumentalnych nie poprawia własności statystycznych równania (np. wartość statystyki Kleibergena-Paap wskazuje na tzw. problem ,słabych instrumentów”). Wniosek taki nie jest zgodny z oczekiwaniami oraz wnioskami Kapetaniosa i Marcellino (2010), choć został otrzymany już w naszych poprzednich badaniach dla Polski (Baranowski, 2011b), gdzie stosowaliśmy nieco inny zestaw zmiennych tworzących wspólne czynniki oraz próbę kończącą się na III kw. 2010.

Przyznajemy, że podejście data-rich jest interesujące ekonomicznie. Dzięki niemu można bowiem za pomocą prostej reguły uwzględnić również przypadek,

${ }^{14}$ Ze względu na postulat silnego skorelowania zmiennych instrumentalnych ze zmiennymi endogenicznymi, wybrano najsilniej skorelowane z przyszłą inflacją i luką produkcyjną, którymi okazały się być: drugi wspólny czynnik (bieżący i opóźniony o 1 kwartał) oraz trzeci wspólny czynnik (bieżący). Wyniki w tym zakresie udostępnimy na życzenie. 
gdy władze monetarne biorą pod uwagę dużą ilość wskaźników gospodarczych. $\mathrm{Z}$ tego względu będzie ono przedmiotem naszych dalszych badań ${ }^{15}$.

\section{Badanie stabilności parametrów}

Stabilność ocen parametrów poszczególnych wariantów reguły Taylora badano przede wszystkim za pomocą regresji kroczącej, na podstawie rozszerzających się podprób (recursive sample). Pozwala to ocenić jakość równań oraz zbadać czy w okresie analizy nie następowały znaczące zmiany w sposobie prowadzenia polityki pieniężnej. Ponadto zweryfikowano hipotezę o skokowych zmianach parametrów związanych ze zmianą kadencji Rady Polityki Pieniężnej. Analizy te pozwolą zweryfikować hipotezę H3, stanowiącą, że parametry reguły stopy procentowej są stabilne w czasie.

\section{Reguła adaptacyjna}

Na wykresach 5-8 przedstawiono: linią pogrubioną punktową ocenę parametru, cienkimi liniami punktową ocenę parametru $+/-2$ błędy szacunku parametru (co odpowiada ok. $95 \%$ przedziałom ufności). Na osi poziomej przedstawiono koniec próby.

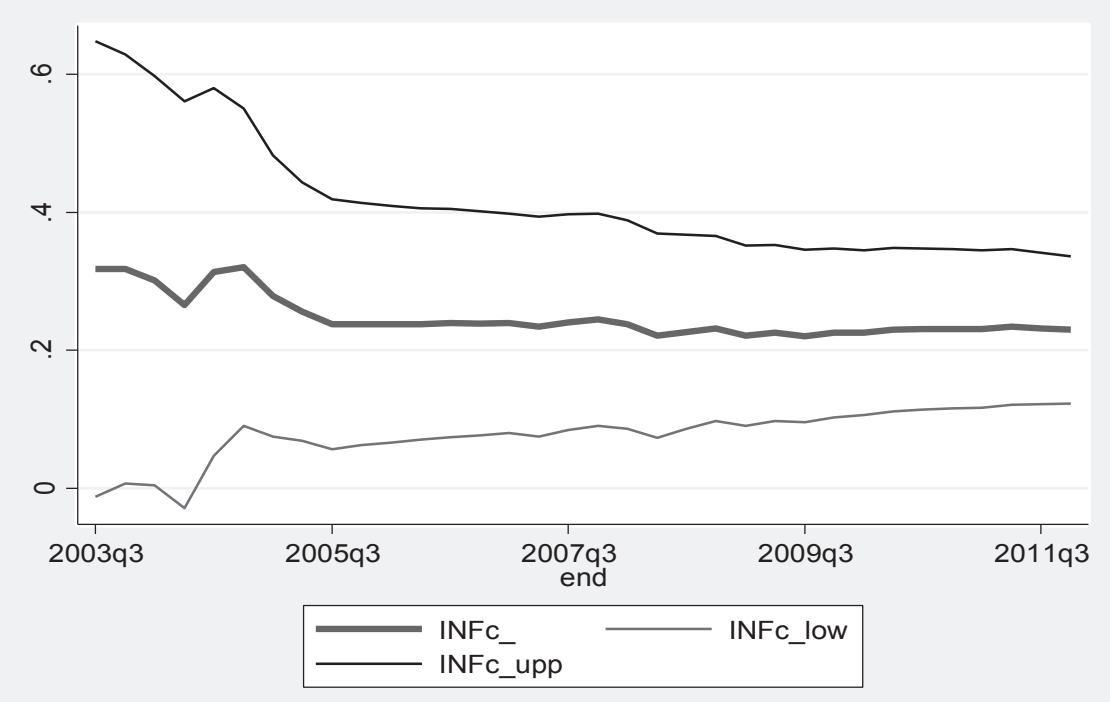

Wykres 5. Parametr przy inflacji $\left(\phi_{\pi}\right)$ wraz z 95\% przedziałem ufności (reguła adaptacyjna)

${ }^{15}$ Możliwe kroki prowadzące do poprawy wyników obejmują przede wszystkim inny dobór zmiennych na potrzeby wspólnego czynnika lub wykorzystanie w charakterze zmiennych instrumentalnych jednocześnie wspólnych czynników i innych zmiennych. Rozważymy także zmianę metody estymacji wspólnych czynników. 


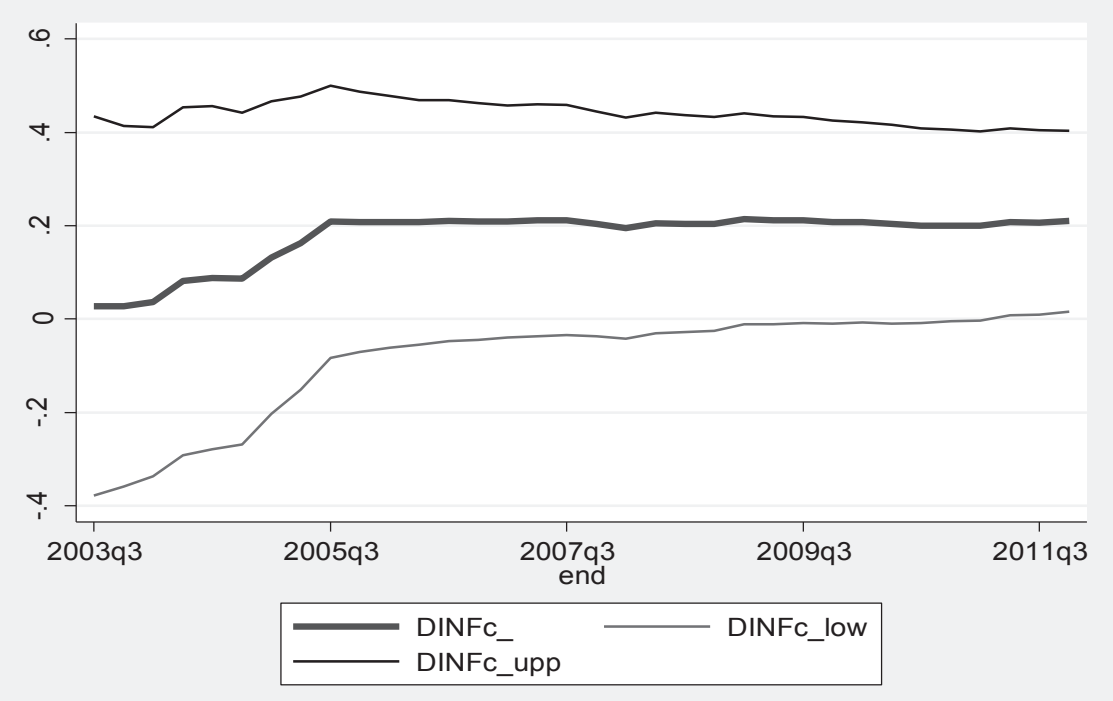

Wykres 6. Parametr przy przyroście inflacji $\left(\phi_{\Delta \pi}\right)$ wraz z 95\% przedziałem ufności (reguła adaptacyjna)

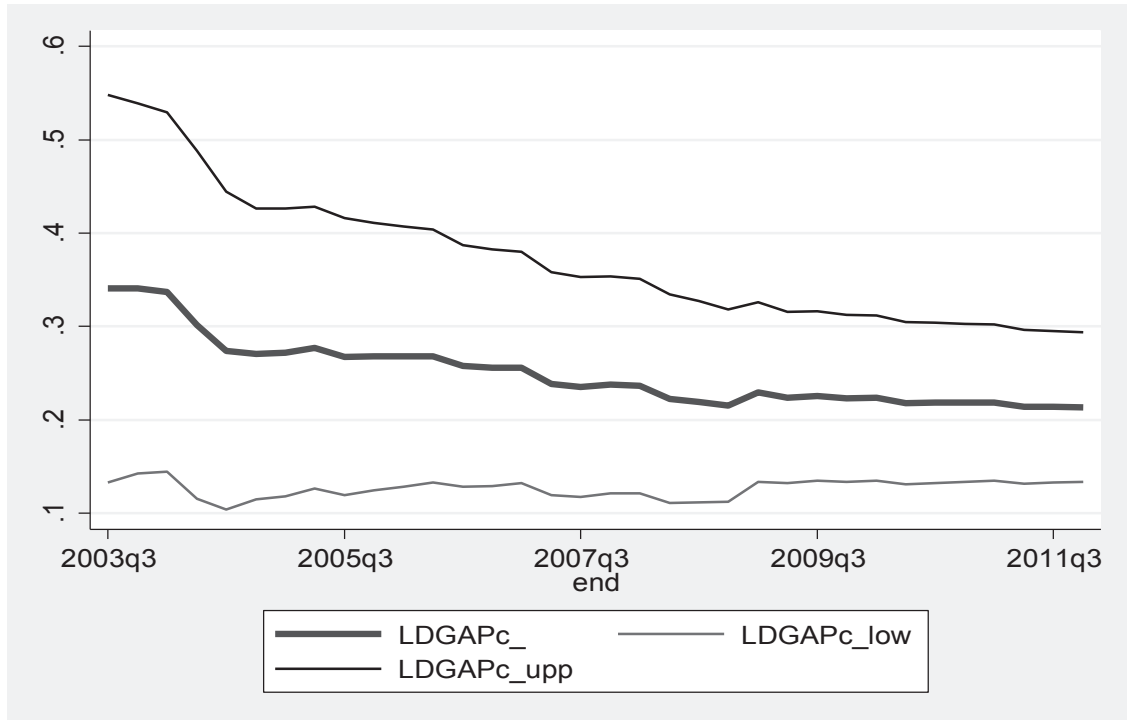

Wykres 7. Parametr przy przyroście luki produkcyjnej $\left(\phi_{\Delta x}\right)$ wraz z 95\% przedziałem ufności (reguła adaptacyjna) 


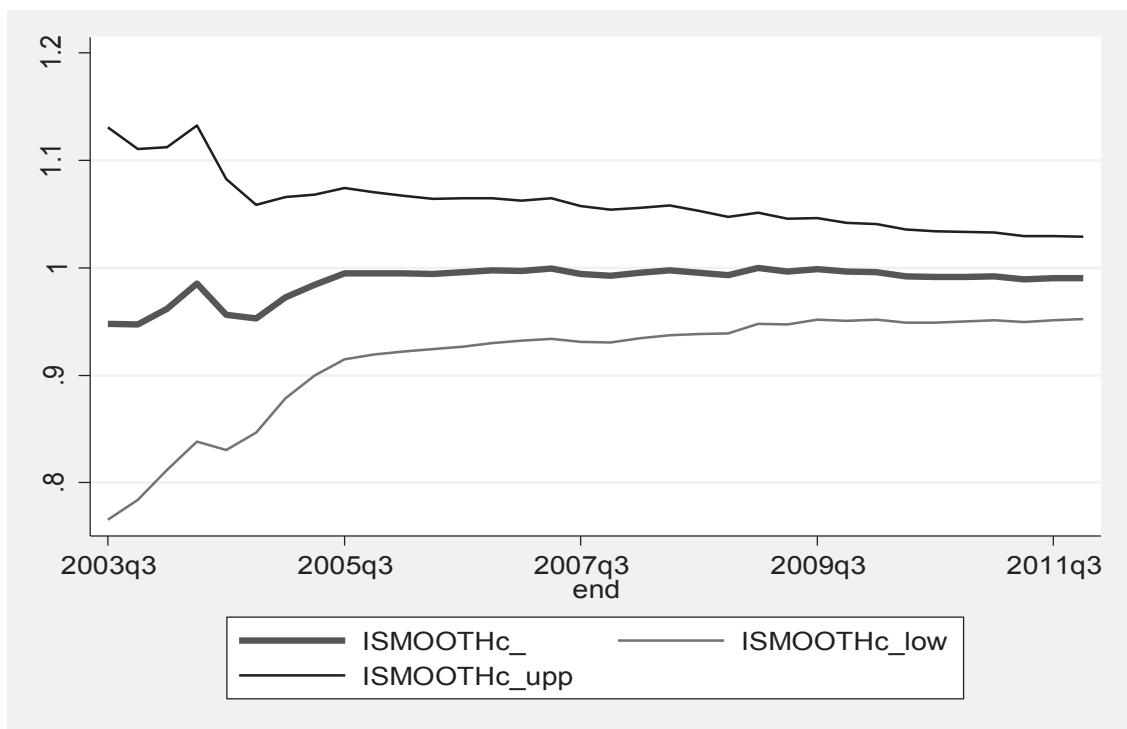

Wykres 8. Parametr wygładzania stóp procentowych wraz z 95\% przedziałem ufności (reguła adaptacyjna)

Otrzymane wyniki wskazują, że parametry są stabilne - stosunkowo największe zmiany ocen parametrów występowały w podpróbach kończących się w latach 2003-2005. Ponadto w podpróbach kończących się w 2005 roku (i później), przedział ufności obejmował wartość zerową jedynie w przypadku parametru związanego z przyrostem inflacji (zob. wykres 6). Możemy również zaobserwować zmniejszanie szerokości (,zawężanie”) przedziałów ufności wraz ze wzrostem liczebności próby. 


\section{Reguła bieżąca}

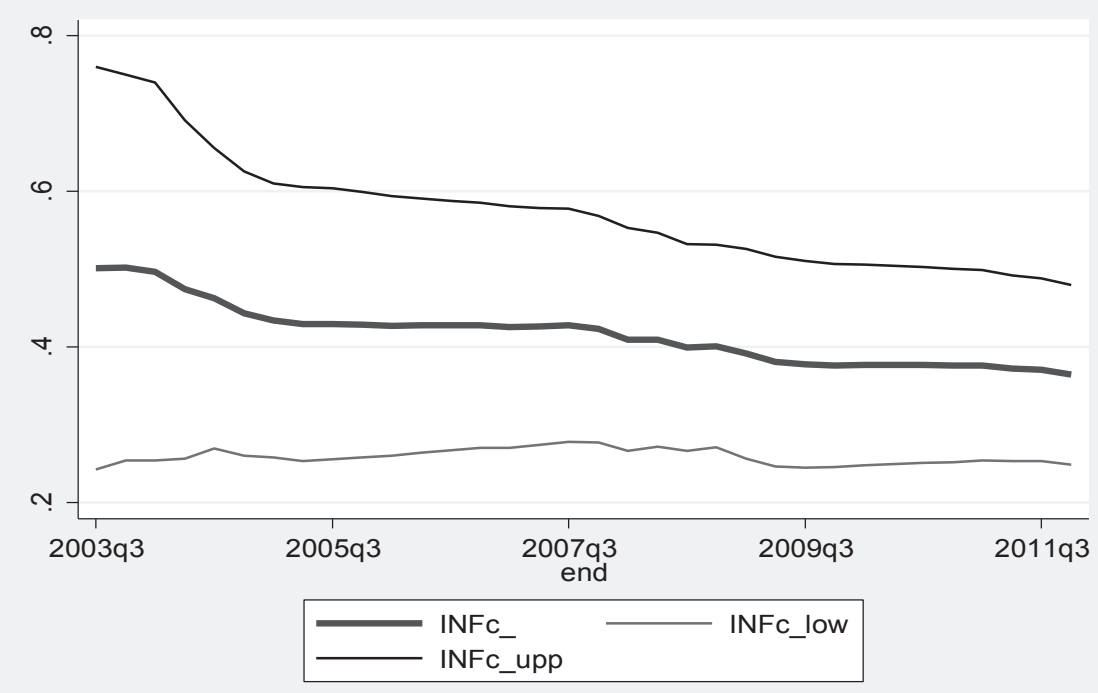

Wykres 9. Parametr przy inflacji $\left(\phi_{\pi}\right)$ wraz z 95\% przedziałem ufności (reguła bieżąca)

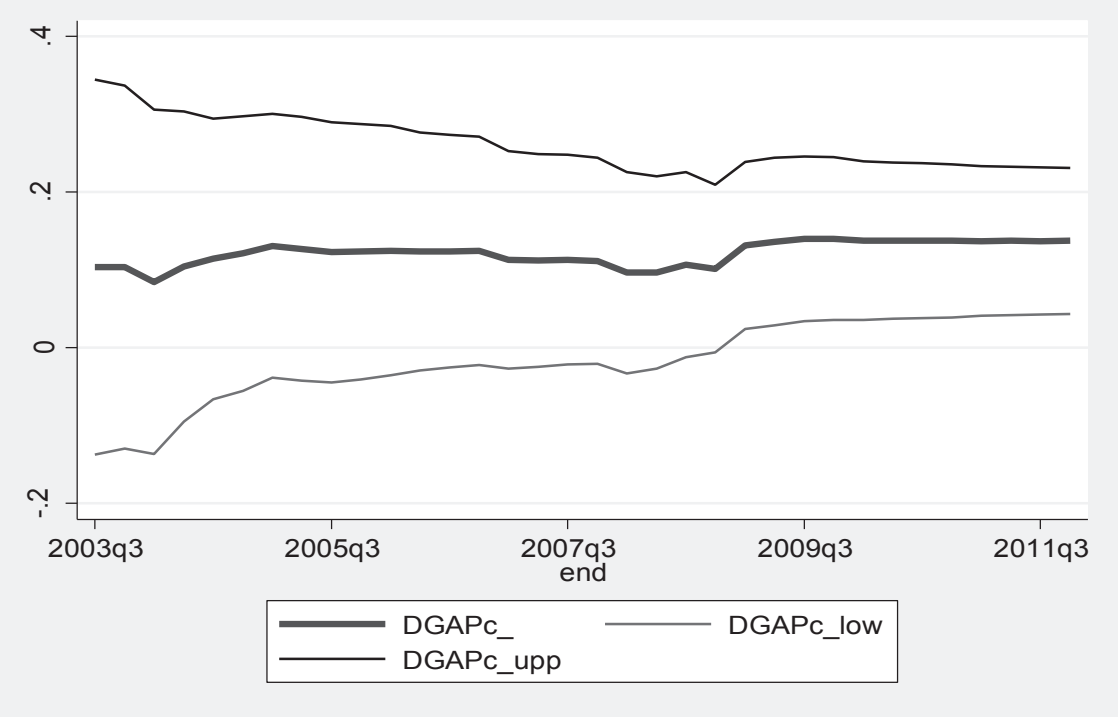

Wykres 10. Parametr przy przyroście luki produkcyjnej $\left(\phi_{\Delta x}\right)$ wraz z 95\% przedziałem ufności (reguła bieżąca) 


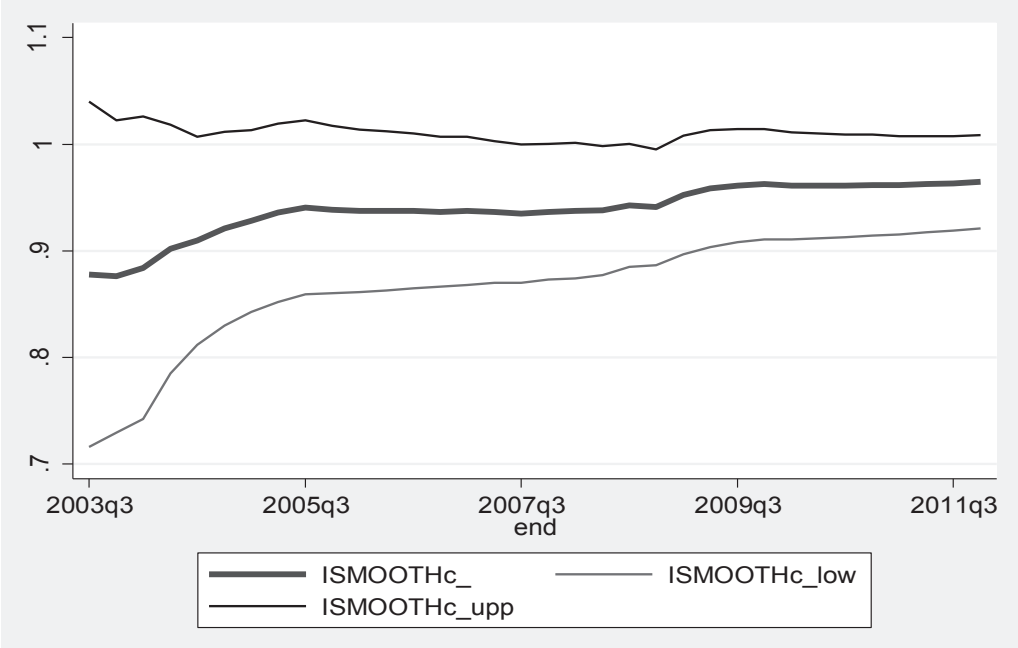

Wykres 11. Parametr wygładzania stóp procentowych wraz z 95\% przedziałem ufności (reguła bieżąca)

Otrzymane wyniki są zbliżone do tych, które pokazaliśmy dla reguły adaptacyjnej. Nie obserwujemy większych zmian ocen parametrów, co oznacza że parametry można uznać za stabilne. Przedział ufności obejmował wartość zerową jedynie w przypadku parametru związanego z przyrostem inflacji. Wraz ze wzrostem próby możemy zauważyć „zawężanie” przedziałów ufności.

\section{Regula antycypacyjna}

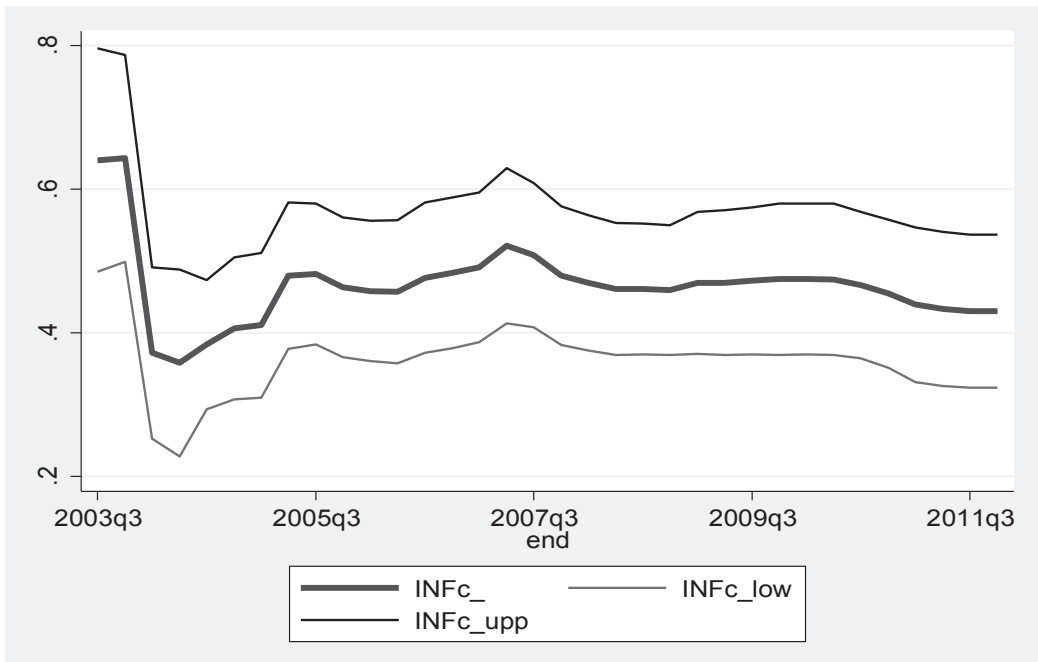

Wykres 12. Parametr przy inflacji ( $\phi_{\pi}$ ) wraz z 95\% przedziałem ufności (reguła antycypacyjna) 


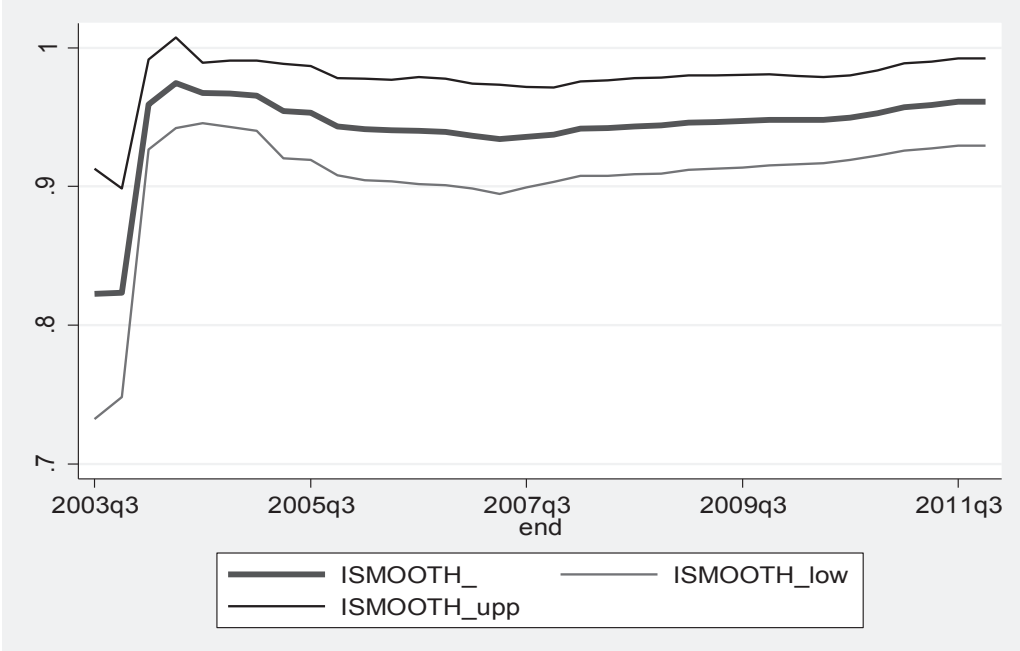

Wykres 13. Parametr wygładzania stóp procentowych wraz z 95\% przedziałem ufności (reguła antycypacyjna)

Otrzymane wyniki wskazują na brak stabilności parametrów w podpróbach kończących się przed II kw. 2004. Przy dłuższych podpróbach parametry można uznać za stabilne. Przedziały ufności obu parametrów nie obejmowały wartości zerowej. $Z$ oceny precyzji oszacowań parametrów przez pryzmat szerokości przedziałów ufności, wynika że parametry są oszacowane precyzyjnie. Jednak w przeciwieństwie do analogicznych analiz dla reguły adaptacyjnej i bieżącej (zob. wykresy 5-11) nie obserwujemy zmniejszania szerokości przedziałów ufności wraz ze wzrostem liczebności próby ${ }^{16}$. Przy czym ma to o tyle mniejsze znaczenie, że precyzja szacunku parametrów jest i tak wysoka dla wszystkich analizowanych podprób.

\section{Zmiany kadencji}

Sposób prowadzenia polityki pieniężnej, opisywany przez regułę Taylora może ulegać zmianom w momencie zmian kadencji organu decyzyjnego banku centralnego. Dlatego też postanowiliśmy zweryfikować hipotezę H3 - o stałości parametrów oszacowanych wcześniej reguł, przeciwko hipotezie alternatywnej o skokowych zmianach w momencie zmiany składu Rady Polityki Pieniężnej (RPP).

Formalnym narzędziem weryfikacji tej hipotezy będzie testowanie liniowych restrykcji nakładanych na zmienne interakcyjne ${ }^{17}$. Przykładowo, dla reguły adaptacyjnej oszacujemy równanie o postaci:

${ }^{16}$ Podejrzewamy, że wynika to z różnic metody estymacji (reguła antycypacyjna była estymowana za pomocą uogólnionej metody momentów, a poprzednie - za pomocą MNK). kroczącej.

${ }^{17} \mathrm{~W}$ sposób nieformalny zagadnienie to było analizowane także wcześniej, za pomocą regresji 


$$
\begin{aligned}
i_{t}=i_{0} & +\rho i_{t-1}+\phi_{\pi} \tilde{\pi}_{t-1}+\phi_{\pi}^{\prime} Z_{2, t} \tilde{\pi}_{t-1}+\phi_{\pi}^{\prime \prime} Z_{3, t} \tilde{\pi}_{t-1}+\phi_{\Delta \pi} \Delta \tilde{\pi}_{t-1}+\phi_{\Delta \pi}^{\prime} Z_{2, t} \Delta \tilde{\pi}_{t-1} \\
& +\phi_{\Delta \pi}^{\prime \prime} Z_{3, t} \Delta \tilde{\pi}_{t-1}+\phi_{\Delta x} \Delta x_{t-1}+\phi_{\Delta x}^{\prime} Z_{2, t} \Delta x_{t-1}+\phi_{\Delta x}^{\prime \prime} Z_{3, t} \Delta x_{t-1}+\epsilon_{t}
\end{aligned}
$$

gdzie:

$Z_{2, t}, Z_{3, t}$ - zmienne zerojedynkowe, przyjmujące wartości 1 dla okresu odpowiednio drugiej i trzeciej kadencji RPP (tj. 2004-2010 i od 2011).

a następnie przetestujemy kolejno następujące restrykcje:

$$
\begin{gathered}
\phi_{\pi}^{\prime}=\phi_{\pi}^{\prime \prime}=0 \\
\phi_{\Delta \pi}^{\prime}=\phi_{\Delta \pi}^{\prime \prime}=0 \\
\phi_{\Delta x}^{\prime}=\phi_{\Delta x}^{\prime \prime}=0
\end{gathered}
$$

Weryfikacji powyższych hipotez dokonamy za pomocą testu istotności liniowych restrykcji narzucanych na parametry, opartych na statystyce F ( $\mathrm{tj}$. testu Chowa; dla reguły antycypacyjnej i bieżącej, estymowanych MNK) oraz chi-kwadrat (dla reguły antycypacyjnej, estymowanej uogólnioną metodą momentów).

W tab. 3.3 przedstawiono wartości statystyk odpowiednich testów (w nawiasach podano empiryczny poziom istotności).

Tabela 3.3. Wyniki testów stabilności parametrów

\begin{tabular}{|c|c|c|c|}
\hline \multirow{2}{*}{ Zmienna } & \multicolumn{3}{|c|}{ Reguła } \\
\cline { 2 - 4 } & adaptacyjna & bieżąca & antycypacyjna \\
\hline$\tilde{\pi}_{t}$ & $0,84(43,7 \%)$ & $0,44(64,4 \%)$ & $3,68(15,9 \%)$ \\
\hline$\Delta \tilde{\pi}_{t}$ & $3,03(5,9 \%)$ & Nie dotyczy & Nie dotyczy \\
\hline$\Delta_{t}$ & $7,82(0,1 \%)$ & $0,23(79,4 \%)$ & Nie dotyczy \\
\hline
\end{tabular}

Źródło: obliczenia własne.

Wyniki pozwalają wnioskować, że większość parametrów opisujących reakcję polityki na inflację, przyrost inflacji i przyrost luki produkcyjnej, nie ulegała 
zmianie wraz ze zmianą kadencji RPP. Jedynie w przypadku przyrostu luki produkcyjnej w regule adaptacyjnej otrzymano istotne różnice w parametrze oszacowanym dla poszczególnych kadencji RPP. W pozostałych przypadkach możemy formalnie potwierdzić hipotezę H3 i stwierdzić, że parametry reguły stopy procentowej są stabilne w czasie.

\section{Podsumowanie}

W rozdziale przedstawiono wyniki estymacji równań reguły polityki pieniężnej dla Polski, przyjmując jako wyjściową specyfikację regułę Taylora z wygładzaniem stóp procentowych - w wersji adaptacyjnej (opóźniona reakcja na inflację i lukę), bieżącej (bieżąca reakcja na inflację i lukę) i antycypacyjnej (reakcja na przyszłą, oczekiwaną inflację i lukę).

Wyniki otrzymane dla wszystkich trzech postaci reguł wskazują, że polskie władze monetarne bardzo silnie reagują na odchylenie inflacji od celu - trwały wzrost inflacji o $1 \mathrm{p}$. proc. powoduje wzrost stóp procentowych o około $10 \mathrm{p}$. proc. (reguła bieżąca i antycypacyjna) lub nawet o ponad 20 p. proc. (reguła adaptacyjna). Jeśli natomiast założymy, że wspominany wyżej wzrost inflacji powyżej celu potrwa 6 kwartałów, wówczas możemy spodziewać wzrostu stóp w granicach od 1,3 p. proc. (reguła adaptacyjna) do 2,3 p. proc. (reguła antycypacyjna). Reakcja na lukę produkcyjną jest nieistotna statystycznie, choć w wariancie adaptacyjnym i bieżącym można stwierdzić istotny wpływ jej przyrostu. Wyniki te pozwalają częściowo potwierdzić hipotezę H1 - w zakresie wpływu inflacji na stopy procentowe.

Można również stwierdzić, że reakcja banku centralnego jest bardzo rozłożona w czasie - występuje silne (parametr wygładzania stóp procentowych ponad $0,95)$ i istotne statystycznie wygładzanie stóp procentowych - tym samym potwierdzono hipotezę H2.

Analizowaliśmy również interesujący ekonomicznie wariant reguły antycypacyjnej, w którym bank centralny może reagować na wiele zmiennych (podejście określane jako data-rich). Wyniki oszacowań parametrów były zbliżone do tych, które otrzymaliśmy dla „standardowej” reguły antycypacyjnej. Jednakże gorsze wyniki testów weryfikujących prawidłowość doboru instrumentów sprawiają, że wariant ten nie może być uznany za w pełni poprawny.

Stosując regresję dla rozszerzających się podprób stwierdziliśmy, że oceny parametrów są stosunkowo stabilne, a przedziały ufności nie obejmują zera (z wyjątkiem oceny przy przyroście luki w wariancie bieżącym dla krótszych podprób). Hipotezę H3 (o stabilności ocen parametrów) weryfikowano również w sposób formalny, testując zmiany parametrów pomiędzy podpróbami odpowiadającymi kadencjom Rady Polityki Pieniężnej. Z wyjątkiem parametru związanego z przyrostem luki produkcyjnej w regule adaptacyjnej, nie stwierdzono statystycznie 
istotnych różnic wielkości parametrów, a zatem można uznać iż hipotezę H3 potwierdzono.

Można przyjąć, że wszystkie trzy oszacowane przez nas warianty reguły Taylora znajdują potwierdzenie w danych i stąd szacunki te możemy przyjąć jako dobre przybliżenie funkcji reakcji polityki pieniężnej. Dodatkowo, możemy stwierdzić że otrzymane wyniki są stosunkowo odporne na zmianę sposobu pomiaru luki produkcyjnej ${ }^{18}$.

${ }^{18}$ Wyniki te zawarte są w Załączniku 3.4. 


\section{Załącznik 3.1. \\ Opis zmiennych użytych do analizy czynnikowej}

Wykorzystano 50 szeregów o częstotliwości kwartalnej, odsezonowanych przy pomocy procedury Tramo/Seats i przekształconych do szeregów stacjonarnych. Zmienne, po wprowadzeniu opóźnień publikacyjnych (tzn. opóźnień stosownie do kalendarza udostępniania danych statystycznych; przyjęto, że dane gromadzone są 20 dnia każdego miesiąca) zostały następnie wystandaryzowane.

Warto dodać, że w pracach empirycznych wykorzystujących zmienne czynnikowe często stosuje się większe zbiory danych, zawierające nawet 200 zmiennych. Badania Boivin i Ng (2006) sugerują, iż większy zbiór danych niekoniecznie jest lepszym wyborem, w przeprowadzonych tam bowiem eksperymentach prognostycznych mniejszy zbiór danych pozwalał uzyskać lepsze prognozy. Co istotne, Szafrański (2013) otrzymał analogiczne wyniki przy prognozowaniu inflacji w Polsce. $Z$ tego względu uważamy liczbę 50 szeregów za wystarczającą dla naszych zastosowań.

Ze zbioru tak przekształconych zmiennych wyznaczono trzy główne składowe (odpowiednio: $f 1_{t}, f 2_{t}, f 3_{t}$ ), przy pomocy klasycznej metody głównych składowych (Principal Components).

Tabela Z-1. Zestawienie szeregów wykorzystanych do konstrukcji głównych składowych $(f 1$ i $f 2)$

\begin{tabular}{|l|c|c|c|c|}
\hline \multicolumn{1}{|c|}{ Nazwa grupy } & Liczba szeregów & Transformacja & Opóźnienie publik. & Źródło \\
\hline 1 & 2 & 3 & 4 & 5 \\
\hline $\begin{array}{l}\text { Wskaźniki koniunk- } \\
\text { tury* }\end{array}$ & 8 & Przyrost & 0 kwart. & GUS \\
\hline $\begin{array}{l}\text { Wskaźniki koniunk- } \\
\text { tury* }\end{array}$ & 2 & Brak & 0 kwart. & GUS \\
\hline $\begin{array}{l}\text { Ceny surowców } \\
\text { na rynkach świat.* }\end{array}$ & 11 & Tempo & 0 kwart. & MFW \\
\hline $\begin{array}{l}\text { Stopy WIBOR (term } \\
\text { structure)** }\end{array}$ & 2 & Brak & 0 kwart. & Reuters \\
\hline Kursy walutowe** & 3 & Tempo & 0 kwart. & NBP \\
\hline Składniki PKB & 4 & Tempo & 1 kwart. & GUS \\
\hline $\begin{array}{l}\text { Oczekiwania infla- } \\
\text { cyjne* }\end{array}$ & 2 & Brak & 1 kwart. & NBP \\
\hline Podaż pieniądza* & 5 & Tempo & 1 kwart. & NBP \\
\hline
\end{tabular}




\begin{tabular}{|l|c|c|c|c|}
\hline \multicolumn{1}{|c|}{1} & 2 & 3 & 4 & 5 \\
\hline $\begin{array}{l}\text { Ceny paliw na rynku } \\
\text { detalicznym*** }\end{array}$ & 2 & Tempo & 0 kwart. & E-petrol \\
\hline Inne & 2 & Tempo lub brak & 0 lub 1 kwart. & GUS \\
\hline $\begin{array}{l}\text { PKB zagranicz- } \\
\text { ne**** }\end{array}$ & 4 & Tempo & 1 kwart. & Eurostat \\
\hline \multicolumn{1}{|c|}{ Inne***** } & 6 & Tempo lub brak & 0 lub 1 kwart. & GUS \\
\hline
\end{tabular}

Objaśnienia:

* Dane miesięczne, zagregowane.

** Dane dzienne, zagregowane.

*** Dane tygodniowe, zagregowane.

**** Niemcy, Francja, strefa Euro, Stany Zjednoczone.

***** Dane nt. produkcji, bezrobocie BAEL, wskaźnika cen PPI, sprzedaż detaliczna.

Źródło: opracowanie własne (dotyczy tab. Z1-Z4).

\section{Załącznik 3.2. \\ Wrażliwość wyników - reguła adaptacyjna}

W tab. Z-2 prezentujemy wyniki estymacji reguł adaptacyjnych o opóźnieniach $l=1,2,3$ oraz $k=1,2,3$. Oszacowaniu podlegał początkowy wariant równania rozszerzonej reguły Taylora (w celu zachowania porównywalności wszystkie warianty były szacowane na krótszej, jednolitej próbie - od I kw. 2000 do III kw. 2012):

$$
i_{t}=i_{0}+\rho i_{t-1}+\phi_{\pi} \pi_{t-k}+\phi_{x} x_{t-l}+\phi_{\Delta \pi} \Delta \pi_{t-k}+\phi_{\Delta x} \Delta x_{t-l}+\varepsilon_{t}
$$

Tabela Z-2. Szacunki reguły adaptacyjnej w zależności od przyjętych opóźnień

\begin{tabular}{|c|c|c|c|c|c|c|c|}
\hline \multirow{2}{*}{$\begin{array}{c}\text { Rząd } \\
\text { opóźnieńn }\end{array}$} & $l=1$ & $l=1$ & $l=2$ & $l=2$ & $l=2$ & $l=3$ & $l=3$ \\
\cline { 2 - 8 } & $k=1$ & $k=2$ & $k=1$ & $k=2$ & $k=3$ & $k=2$ & $k=3$ \\
\hline 1 & 2 & 3 & 4 & 5 & 6 & 7 & 8 \\
\hline Zmienna & & \multicolumn{7}{|c|}{ Oceny parametrów (statystyki $t$-Studenta) } \\
\hline$i_{t-1}$ & $\begin{array}{c}0,959 \\
(68,4)\end{array}$ & $\begin{array}{c}0,960 \\
(72,3)\end{array}$ & $\begin{array}{c}0,951 \\
(42,3)\end{array}$ & $\begin{array}{c}0,955 \\
(58,9)\end{array}$ & $\begin{array}{c}0,954 \\
(53,3)\end{array}$ & $\begin{array}{c}0,979 \\
(36,8)\end{array}$ & $\begin{array}{c}0,952 \\
(49,5)\end{array}$ \\
\hline \multirow{2}{*}{$\tilde{\pi}_{t-k}$} & $\begin{array}{c}0,256 \\
(5,7)\end{array}$ & $\begin{array}{c}0,253 \\
(5,9)\end{array}$ & $\begin{array}{c}0,0968 \\
(1,7)\end{array}$ & $\begin{array}{c}0,129 \\
(2,5)\end{array}$ & $\begin{array}{c}0,108 \\
(1,9)\end{array}$ & $\begin{array}{c}-0,00446 \\
(-0,1)\end{array}$ & $\begin{array}{c}0,180 \\
(0,3)\end{array}$ \\
\hline
\end{tabular}


Tabela Z-2. (cd.)

\begin{tabular}{|c|c|c|c|c|c|c|c|}
\hline 1 & 2 & 3 & 4 & 5 & 6 & 7 & 8 \\
\hline$x_{t-l}$ & $\begin{array}{c}-0,0040 \\
(-0,3)\end{array}$ & $\begin{array}{c}-0,0153 \\
(-1,5)\end{array}$ & $\begin{array}{c}0,0202 \\
(1,7)\end{array}$ & $\begin{array}{c}0,0255 \\
(0,2)\end{array}$ & $\begin{array}{c}-0,0738 \\
(-0,6)\end{array}$ & $\begin{array}{c}0,0110 \\
(0,6)\end{array}$ & $\begin{array}{c}0,0048 \\
(0,3)\end{array}$ \\
\hline$\Delta \tilde{\pi}_{t-k}$ & $\begin{array}{c}0,182 \\
(2,8)\end{array}$ & $\begin{array}{c}0,120 \\
(1,8)\end{array}$ & $\begin{array}{c}0,248 \\
(3,1)\end{array}$ & $\begin{array}{c}0,194 \\
(2,6)\end{array}$ & $\begin{array}{c}0,168 \\
(1,9)\end{array}$ & $\begin{array}{c}0,323 \\
(2,6)\end{array}$ & $\begin{array}{c}0,141 \\
(1,6)\end{array}$ \\
\hline $\begin{array}{c}\Delta x_{t-l} \\
(4,7)\end{array}$ & $\begin{array}{c}0,158 \\
(5,5)\end{array}$ & $\begin{array}{c}0,125 \\
(3,0)\end{array}$ & $\begin{array}{c}0,180 \\
(5,1)\end{array}$ & $\begin{array}{c}0,162 \\
(4,3)\end{array}$ & $\begin{array}{c}0,140 \\
(2,5)\end{array}$ & $\begin{array}{c}0,182 \\
(4,5)\end{array}$ \\
\hline $\begin{array}{c}\text { Wyraz } \\
\text { wolny }\end{array}$ & 0,038 & 0,025 & 0,063 & 0,097 & 0,093 & 0,055 & 0,124 \\
\hline $\mathrm{R}^{2}$ & 0,993 & 0,989 & 0,994 & 0,991 & 0,988 & 0,987 & 0,987 \\
\hline $\begin{array}{c}\text { LM(1) } \\
(\mathrm{p} v a l u e)\end{array}$ & $\begin{array}{c}0,002 \\
(96,9) \%\end{array}$ & $\begin{array}{c}0,028 \\
(86,7 \%)\end{array}$ & $\begin{array}{c}0,069 \\
(79,3 \%)\end{array}$ & $\begin{array}{c}0,170 \\
(68,0 \%)\end{array}$ & $\begin{array}{c}0,670 \\
(41,3 \%)\end{array}$ & $\begin{array}{c}0,511 \\
(47,5 \%)\end{array}$ & $\begin{array}{c}2,049 \\
(0,152)\end{array}$ \\
\hline $\begin{array}{c}\mathrm{LM}(4) \\
(\mathrm{pvalue})\end{array}$ & $\begin{array}{c}1,351 \\
(85,3) \%\end{array}$ & $\begin{array}{c}2,816 \\
(58,9 \%)\end{array}$ & $\begin{array}{c}4,870 \\
(30,1 \%)\end{array}$ & $\begin{array}{c}1,061 \\
(90,0 \%)\end{array}$ & $\begin{array}{c}7,308 \\
(12,1 \%)\end{array}$ & $\begin{array}{c}3,054 \\
(54,9 \%)\end{array}$ & $\begin{array}{c}8,597 \\
(0,072)\end{array}$ \\
\hline
\end{tabular}

\section{Załącznik 3.3.}

\section{Wrażliwość wyników - reguła antycypacyjna}

W tab. Z-3 przedstawiamy wyniki estymacji reguł adaptacyjnych o horyzoncie oczekiwań $m=1$, 2, 3 oraz $m=1,2,3$.. Podobnie jak w tab. Z-2 szacowano początkowy wariant równania, a w celu zachowania porównywalności wszystkie warianty były szacowane na wspólnej próbie:

$$
i_{t}=i_{0}+\rho i_{t-1}+\phi_{\pi} \boldsymbol{E}_{t}\left(\pi_{t+m}\right)+\phi_{x} \boldsymbol{E}_{t}\left(\pi_{t+n}\right)+\varepsilon_{t}
$$

Tabela Z-3. Szacunki reguły antycypacyjnej w zależności od przyjętych opóźnień

\begin{tabular}{|c|c|c|c|c|c|c|c|}
\hline $\begin{array}{c}\text { Rząd opóź- } \\
\text { nień }\end{array}$ & $m=1$ & $m=1$ & $m=2$ & $m=2$ & $m=2$ & $m=3$ & $m=3$ \\
\cline { 2 - 8 } & $n=1$ & $n=2$ & $n=1$ & $n=2$ & $n=3$ & $n=2$ & $n=3$ \\
\hline 1 & 2 & 3 & 4 & 5 & 6 & 7 & 8 \\
\hline Zmienna & & \multicolumn{7}{|c|}{ Oceny parametrów (statystyki $t$-Studenta) } \\
\hline$i_{t-1}$ & $\begin{array}{c}0,961 \\
(59,6)\end{array}$ & $\begin{array}{c}0,961 \\
(61,1)\end{array}$ & $\begin{array}{c}0,929 \\
(33,7)\end{array}$ & $\begin{array}{c}0,925 \\
(33,2)\end{array}$ & $\begin{array}{c}0,922 \\
(32,6)\end{array}$ & $\begin{array}{c}0,990 \\
(37,0)\end{array}$ & $\begin{array}{c}0,897 \\
(24,0)\end{array}$ \\
\hline
\end{tabular}




\begin{tabular}{|c|c|c|c|c|c|c|c|}
\hline 1 & 2 & 3 & 4 & 5 & 6 & 7 & 8 \\
\hline $\boldsymbol{E}_{\boldsymbol{t}}\left(\tilde{\pi}_{t+m}\right)$ & $\begin{array}{c}0,416 \\
(5,3)\end{array}$ & $\begin{array}{c}0,417 \\
(5,7)\end{array}$ & $\begin{array}{c}0,288 \\
(4,3)\end{array}$ & $\begin{array}{c}0,300 \\
(4,3)\end{array}$ & $\begin{array}{c}0,306 \\
(4,3)\end{array}$ & $\begin{array}{c}-0,131 \\
()\end{array}$ & $\begin{array}{c}0,213 \\
(1,5)\end{array}$ \\
\hline $\boldsymbol{E}_{\boldsymbol{t}}\left(x_{t+n}\right)$ & $\begin{array}{c}0,002 \\
(0,1)\end{array}$ & $\begin{array}{c}0,002 \\
(0,1)\end{array}$ & $\begin{array}{c}0,017 \\
(1,3)\end{array}$ & $\begin{array}{c}0,014 \\
(1,1)\end{array}$ & $\begin{array}{c}0,0139 \\
(0,9)\end{array}$ & $\begin{array}{c}0,114 \\
()\end{array}$ & $\begin{array}{c}0,023 \\
(0,8)\end{array}$ \\
\hline Wyraz & 0,130 & 0,127 & 0,239 & 0,251 & 0,269 & $-0,252$ & 0,316 \\
\hline wolny & 0,982 & 0,983 & 0,976 & 0,975 & 0,978 & 0,975 & 0,977 \\
\hline $\mathrm{R}^{2}$ & 1,6 & $\begin{array}{c}1,6 \\
(45 \%)\end{array}$ & $\begin{array}{c}3,5 \\
(17 \%)\end{array}$ & $\begin{array}{c}3,4 \\
(18 \%)\end{array}$ & $\begin{array}{c}3,4 \\
(18 \%)\end{array}$ & $\begin{array}{c}4,3 \\
(11 \%)\end{array}$ & $\begin{array}{c}4,0 \\
(14 \%)\end{array}$ \\
\hline $\mathrm{J}$ & $(45 \%)$ &
\end{tabular}

Zmienne instrumentalne: $\tilde{\pi}_{t-1}, x_{t-1}, p p i_{t-1}, \Delta$ eurpln ${ }_{t-1}$.

Z kolei w tab. Z-4 przedstawiamy odporność wyników estymacji antycypacyjnej reguły Taylora ze względu na dobór zmiennych instrumentalnych (zarówno dla ,standardowych" zmiennych instrumentalnych, jak i zmiennych otrzymanych na podstawie analizy czynnikowej).

Tabela Z-4. Szacunki reguły antycypacyjnej przy alternatywnych zestawach instrumentów

\begin{tabular}{|c|c|c|c|c|c|c|}
\hline Zmienna & \multicolumn{7}{|c|}{ Oceny parametrów (statystyki $t$-Studenta) } \\
\hline$i_{t-1}$ & $\begin{array}{c}0,990 \\
(52,2)\end{array}$ & $\begin{array}{c}0,970 \\
(52,2)\end{array}$ & $\begin{array}{c}0,960 \\
(44,8)\end{array}$ & $\begin{array}{c}0,968 \\
(63,1)\end{array}$ & $\begin{array}{c}0,969 \\
(68,6)\end{array}$ & $\begin{array}{c}0,963 \\
(78,2)\end{array}$ \\
\hline \multirow{2}{*}{$\boldsymbol{E}_{\boldsymbol{t}}\left(\tilde{\pi}_{t+1}\right)$} & $\begin{array}{c}0,372 \\
(3,2)\end{array}$ & $\begin{array}{c}0,319 \\
(3,4)\end{array}$ & $\begin{array}{c}0,374 \\
(3,0)\end{array}$ & $\begin{array}{c}0,390 \\
(3,2)\end{array}$ & $\begin{array}{c}0,404 \\
(5,6)\end{array}$ & $\begin{array}{c}0,348 \\
(4,9)\end{array}$ \\
\hline \multirow{2}{*}{$\boldsymbol{E}_{\boldsymbol{t}}\left(x_{t+1}\right)$} & $\begin{array}{c}-0,007 \\
(-0,4)\end{array}$ & $\begin{array}{c}0,005 \\
(0,4)\end{array}$ & $\begin{array}{c}0,008 \\
(0,5)\end{array}$ & $\begin{array}{c}0,005 \\
(0,2)\end{array}$ & $\begin{array}{c}0,0008 \\
(0,1)\end{array}$ & $\begin{array}{c}0,018 \\
(1,5)\end{array}$ \\
\hline Wyraz wolny & $-0,260$ & 0,031 & 0,031 & 0,086 & 0,072 & 0,181 \\
\hline R ${ }^{2}$ & 0,982 & 0,983 & 0,983 & 0,981 & 0,981 & 0,981 \\
\hline Zmienne in- & $f 1_{t-1}, f 2_{t-2}$, & $f 1_{t-1}, f 1_{t-2}$, & $f 1_{t-1}$, & $\tilde{\pi}_{t-1}, \tilde{\pi}_{t-2}$, & $\tilde{\pi}_{t-1}, \tilde{\pi}_{t-2}$, & $\tilde{\pi}_{t-1}, x_{t-1}$, \\
strumentalne & $f 3_{t-1}, f 3_{t-2}$ & $f 2_{t-1}, f 2_{t-2}$, & $f 2_{t-1}$, & $x_{t-1}, x_{t-2}$ & $x_{t-1}, x_{t-2}$, & $\tilde{\pi}_{t-2}, x_{t-2}$, \\
& $f 3_{t-1}, f 3_{t-2}$ & $f 3_{t-1}$, & $p p i_{t-1}$ & $\tilde{\pi}_{t-3}, x_{t-3}$ \\
\hline K-P & $12,0(10 \%)$ & $13,0(16 \%)$ & $12,8(5 \%)$ & $15,8(1,5 \%)$ & $16,2(2,4 \%)$ & $17,1(3 \%)$ \\
\hline
\end{tabular}




\section{Załącznik 3.4. \\ Wrażliwość wyników - luka produkcyjna wyznaczona za pomocą filtru HP}

Niniejszy załącznik zawiera wyniki dodatkowych estymacji trzech postaci reguł: adaptacyjnej, bieżącej i antycypacyjnej. W przedstawionych poniżej wariantach przyjęto lukę produkcyjną wyznaczoną przy pomocy filtru HodrickaPrescotta, zamiast wyznaczonej jako odchylenie od deterministycznego trendu. Wyniki estymacji są zbliżone do zaprezentowanych wcześniej w rozdziale 3, co świadczy o odporności wyników na zmianę sposobu pomiaru luki.

\section{Adaptacyjna}

$$
\begin{gathered}
i_{t}=0,011+0,972 i_{t-1}+0,216 \tilde{\pi}_{t-1}+0,207 \Delta \tilde{\pi}_{t-1}+0,013 x_{t-1}+0,217 \Delta x_{t-1} \\
(45,8) \quad(2,9) \quad(2,2) \quad(0,5) \quad(4,6) \\
R^{2}=0,985 \quad L M(4)=4,9(p=30,1 \%) \\
i_{t}=-0,019+0,975 i_{t-1}+0,240 \tilde{\pi}_{t-1}+0,207 \Delta \tilde{\pi}_{t-1}+0,230 \Delta x_{t-1} \\
(52,3) \quad(4,5) \quad(2,1) \quad(4,8) \\
R^{2}=0,985 \quad L M(1)=1,8(p=17,8 \%) \quad L M(4)=5,9(p=20,9 \%)
\end{gathered}
$$

\section{Bieżąca}

$$
\begin{gathered}
i_{t}=0,054+0,965 i_{t-1}+0,281 \tilde{\pi}_{t}-0,004 \Delta \tilde{\pi}_{t}+0,034 x_{t}+0,140 \Delta x_{t} \\
(45,8) \quad(3,8) \quad(-0,0) \quad(1,3) \quad(4,6) \\
R^{2}=0,983 \quad L M(1)=1,1(p=30,5 \%) \quad L M(4)=2,9(p=70,4 \%) \\
i_{t}=0,055+0,958 i_{t-1}+0,372 \tilde{\pi}_{t}+0,171 \Delta x_{t} \\
(48,5) \quad(6,8) \quad(3,4) \\
R^{2}=0,980 \quad L M(1)=0,5(p=47,7 \%) \quad L M(4)=4,9(p=30,2 \%)
\end{gathered}
$$

\section{Antycypacyjna}

$$
\begin{gathered}
i_{t}=0,128+0,961 i_{t-1}+0,412 \boldsymbol{E}_{t} \tilde{\pi}_{t+1}+0,004 x_{t} \\
(60,4) \quad(4,3) \quad(0,4) \\
J=1,60(p=44,7 \%)
\end{gathered}
$$




\section{OCZEKIWANE I NIEOCZEKIWANE ZACIEŚNIENIE POLITY- KI PIENIĘŻNEJ DLA GOSPODARKI POLSKI - ANALIZA W WA- RUNKACH RÓŻNYCH REGUL}

\section{Wprowadzenie}

W ostatnim rozdziale przeprowadzimy analizę skutków zacieśnienia polityki pieniężnej, które na potrzeby badania interpretujemy w kontekście egzogenicznego odejścia od reguły polityki pieniężnej (dalej zwanego szokiem polityki pieniężnej). Pozwoli to udzielić odpowiedzi na drugie pytanie badawcze - jak zmienia się inflacja i luka produkcyjna w Polsce pod wpływem szoku polityki pieniężnej?

Analizy przeprowadzimy na podstawie małej skali nowokeynesistowskiego modelu dynamicznej stochastycznej równowagi ogólnej (DSGE) estymowanego dla gospodarki Polski. $Z$ tego względu pierwszą część rozdziału poświęcamy omówieniu podstawowych mechanizmów ekonomicznych występujących w modelach klasy DSGE¹. Parametry strukturalne równania hybrydowej krzywej Phillipsa oraz hybrydowej IS zostaną wyznaczone za pomocą uogólnionej metody momentów (GMM). Symulacje wykonamy równolegle dla trzech rodzajów reguły polityki pieniężnej: adaptacyjnej, standardowej oraz antycypacyjnej, które przyjmujemy na podstawie wyników otrzymanych w poprzednim rozdziale. Porównanie wyników pozwoli zweryfikować hipotezę H4, o znaczących różnicach w reakcji inflacji i luki produkcyjnej po wystąpieniu szoku polityki pieniężnej, w zależności od przyjętej reguły.

Standardowo przyjmuje się, że szoki te nie są oczekiwane i stanowią „niespodziankę" dla podmiotów gospodarczych. Bank centralny może jednak (niekoniecznie wprost) zapowiedzieć zacieśnienie polityki pieniężnej z wyprzedzeniem, co odzwierciedla scenariusz oczekiwanego szoku (przyjęto, że zacieśnienie jest w pełni antycypowane na 4 kwartały wcześniej).

${ }^{1}$ Alternatywną prezentację modeli DSGE w literaturze polskojęzycznej Czytelnik znajdzie w opracowaniach: Kuchta (2011), Baranowski i in. (2012, rozdz. 2), Grabek i Kłos (2012), Krajewski (2013, rozdz. 4.1). Ponadto w pracach: Kokoszczyński (2004, rozdz. 7.4) oraz Welfe (2013) modele tej klasy umiejscowiono na tle wcześniejszych koncepcji modelowania gospodarki narodowej. 


\section{Modele DSGE - uwagi ogólne}

Dynamiczne stochastyczne modele równowagi ogólnej (Dynamic Stochastic General Equlibrium, dalej: DSGE) opisują gospodarkę przez pryzmat pojedynczych podmiotów gospodarczych (tzw. mikropodmiotów): gospodarstw domowych i przedsiębiorstw oraz podmiotów odpowiedzialnych za kształtowanie się polityki gospodarczej. Zachowania reprezentatywnych ${ }^{2}$ mikropodmiotów (tzw. mikropodstawy) opisane za pomocą warunków koniecznych optymalizacji tych zachowań bądź prostych (np. adaptacyjnych) zasad alokacji są następnie agregowane, przez co uzyskuje się równania dynamiki podstawowych zmiennych makroekonomicznych. Polityka gospodarcza jest zwykle opisana za pomocą reguł instrumentów, które jednak cechują się pewną dozą elastyczności, tzn. dopuszcza się krótkookresowe odchylenia od tych reguł. Odchylenia te są ujęte w modelu w postaci egzogenicznych zaburzeń - szoków. W ogólnym przypadku szoki mogą dotyczyć innych elementów modelu (np. szoki technologiczne lub szoki zmieniające subiektywną stopę dyskonta przyszłej konsumpcji). W takim przypadku szoki generują odchylenia od wielkości ustalanych przez mikropodmioty od wielkości w stanie długookresowej równowagi (steady-state). Zasadniczo, wszystkie inne zmienne z wyjątkiem szoków są endogeniczne.

Standardowo przyjmuje się, że gospodarstwa domowe maksymalizują użyteczność, zaś przedsiębiorstwa zysk. Zarówno w przypadku gospodarstw domowych, jak i przedsiębiorstw maksymalizacja przebiega w nieskończonym horyzoncie czasowym ${ }^{3}$, z uwzględnieniem racjonalnych oczekiwań.

Powszechnie uważa się, że zasady rządzące zachowaniami pojedynczych podmiotów są bardziej stabilne w czasie, w szczególności parametry je określające nie ulegają zmianom pod wpływem bieżących i antycypowanych działań polityki gospodarczej. Sprawia to, że modele DSGE są odporne na krytykę Lucasa (zob. np. Brzoza-Brzezina, 2011, s. 113). Inną specyficzną cechą modeli DSGE, wynikającą z zastosowania „mikropodstaw”, jest możliwość głębszej interpretacji ekonomicznej i formalne podejście do wyznaczania specyfikacji równań opisujących agregaty makroekonomiczne.

Modele DSGE zawierają w nazwie określenie „równowaga”. Równowaga ta, naszym zdaniem, występuje w dwu znaczeniach. Po pierwsze - w przypadku, gdy na gospodarkę nie działają szoki, model zbiega do stanu długookresowej

${ }^{2} \mathrm{~W}$ niektórych pracach odchodzi się od modelowania reprezentatywnych podmiotów, dzięki czemu można dopuścić znacznie większą heterogeniczność mikropodmiotów. Tracimy jednak w tym przypadku możliwość rozwiązania algebraicznego (stosuje się wyłącznie symulacje numeryczne).

${ }^{3} \mathrm{~W}$ przypadku gospodarstw domowych wyraża to m.in. troskę o użyteczność przyszłych pokoleń. Zbliżony efekt uzyskuje się w przypadku gdy gospodarstwa domowe nie potrafią dobrze ocenić dalszego „czasu życia” (Acemoglu, 2008, s. 188-190). 
równowagi (steady-state). Modele DSGE najczęściej nie opisują tak rozumianego poziomu długookresowej równowagi (ten jest zazwyczaj stały bądź wyrażony za pomocą egzogenicznego trendu), lecz krótkookresowe odchylenia od tego poziomu. Po drugie - w konstrukcji modelu zakłada się równowagę popytu i podaży na wszystkich rynkach (towarowym, pracy itp.).

Teoretyczny fundament modeli DSGE może stanowić teoria realnego cyklu koniunkturalnego (RBC) bądź nowej ekonomii keynesistowskiej (NK). W przypadku analiz polityki pieniężnej aplikacja modeli wywodzących się z nurtu RBC jest niecelowa, $w$ takich bowiem modelach $\mathrm{z}$ zasady polityka pieniężna jest neutralna zarówno w krótkim, jak i długim okresie, tzn. zmiana instrumentu polityki pieniężnej nie pociąga za sobą zmian kategorii realnych (zob. np. Snowdon, Vane, Wynarczyk, 1998, rozdz. 6.9) ${ }^{4}$ W przypadku modeli NK $\mathrm{NK}^{5}$ zakłada się, że ceny (a niekiedy także inne kategorie nominalne) są sztywne, a przedsiębiorstwa działają w warunkach konkurencji monopolistycznej, co umożliwia ${ }^{6}$ krótkookresową nieneutralność polityki pieniężnej. Jednocześnie w długim okresie polityka pieniężna jest neutralna, w tym sensie że nie występują trwałe odchylenia zmiennych realnych i nominalnych ${ }^{7}$. Z tego względu w niektórych pracach szkołę NK określa się również mianem nowej syntezy neoklasycznej. Od końca lat 90 . XX wieku modele tej klasy zyskują na popularności (można tu wskazać na pionierską pracę Claridy, Galego i Gertlera, 1999) i obecnie stanowią standardowe narzędzie do analizy polityki pieniężnej. Od kilku lat wzrasta liczba badań z użyciem modeli DSGE dla gospodarki Polski. Wśród przykładów takich badań możemy wymienić choćby następujące opracowania: Grabek, Kłos, Utzig-Lenarczyk (2007); Bukowski, Dyrda, Kowal (2008); Bukowski, Koloch, Lewandowski (2009); Kolasa (2009); Grabek, Kłos, Koloch (2010); Brzoza-Brzezina, Makarski (2011); Kuchta (2011); Krajewski (2013).

${ }^{4}$ Zupełnie inaczej kwestia ta wygląda w przypadku analiz polityki fiskalnej, gdzie w ramach modeli RBC możemy rozpatrywać skutki polityki fiskalnej po stronie podażowej, zaś NK - po stronie popytowej (Krajewski, 2013).

${ }^{5} \mathrm{~W}$ literaturze polskiej przegląd tej klasy modeli przedstawiają m.in.: Kokoszczyński (2004, rozdz. 1.6 i 1.7) oraz Bludnik (2010). Natomiast analizę historyczną tego nurtu i opis pierwszych teorii formułowanych przez ,nowych keynesistów” przybliża Wojtyna (2000, rozdz. 3 i 4 ) oraz Bludnik (2012).

${ }^{6}$ Stwierdzenie ,umożliwia” jest nieprzypadkowe, bowiem sztywność cen jest warunkiem koniecznym, ale nie wystarczającym. Przykładowo, w modelach: Caplina i Spulbera (1987) oraz Golosova i Lucasa (2007) pomimo sztywności cen polityka pieniężna nie wpływa na agregatowy produkt.

${ }^{7} \mathrm{~W}$ przypadku zmiennych realnych odpowiada to konsensusowi co do pionowej długookresowej krzywej łącznej podaży. Jednak w przypadku inflacji wydaje się to sprzeczne z tezami wynikającym z modeli niespójności w czasie (np. Kydlanda-Prescotta i Barro-Gordona przedstawionych w rozdz. 1), z których wynika możliwość występowania „skrzywienia inflacyjnego”. Brak „skrzywienia inflacyjnego" nie zaskakuje jednak, gdy weźmiemy pod uwagę, że w modelach DSGE zakłada się stałą regułę instrumentu polityki pieniężnej i pełną wiarygodność. 


\section{Podstawy teoretyczne i specyfikacja modelu}

Podstawą analiz prowadzonych $w$ niniejszym rozdziale będzie małej skali model DSGE z gospodarstwami domowymi oraz przedsiębiorstwami, w którym zakłada się m.in., że (zob. np. Gali, 2008, rozdz. 3):

- gospodarka jest zamknięta, bez inwestycji i udziału państwa;

- jedynym zmiennym czynnikiem produkcji jest praca;

- przedsiębiorstwa produkują zróżnicowane dobra, sprzedawane na rynku o strukturze konkurencji monopolistycznej;

- gospodarstwa domowe czerpią użyteczność z konsumpcji jedynie w okresie, w którym dobra zostały nabyte (nie występują dobra trwałego użytku);

- występuje sztywność cen ${ }^{8}$ typu Calvo;

- rynek pracy ma strukturę konkurencji doskonałej;

- nie występuje sztywność płac;

- rola pieniądza i rynku pieniężnego ogranicza się wyłącznie do międzyokresowego transferu oszczędności gospodarstw domowych;

- jedynym instrumentem banku centralnego jest nominalna stopa procentowa.

W rezultacie model ma stosunkowo prostą strukturę i z założenia nie odtwarza wielu zjawisk występujących w gospodarce jak np. przymusowe bezrobocie, zaburzenia na rynku finansowym, efekty postępu technicznego czy wpływ tendencji występujących w gospodarce światowej. Stoimy jednak na stanowisku, że zjawiska te nie są kluczowe z punktu widzenia analiz polityki pieniężnej, szczególnie w okresie krótkim. Z pełną świadomością tych ograniczeń przypomnijmy pogląd George’a Boxa, który głosił że „wszystkie modele są niepoprawne, lecz niektóre z nich są użyteczne" (Box, Draper, 1987)9. Stosunkowo prosta konstrukcja ekonomiczna pozwala łatwo prześledzić (ceteris paribus) kluczowe elementy konstrukcji modelu na poziomie mikropodstaw i ich rolę dla dynamiki agregatów makroekonomicznych.

Badanie wpływu pominiętych czynników możemy również przeprowadzić, gdy nadamy im postać szoków. Szoki te mogą mieć charakter nietrwały-impulsowy (tzw. szoki białoszumowe) bądź o większym stopniu trwałości (zwykle kształtowane przez procesy autoregresywne pierwszego rzędu). Jednak w każdym

${ }^{8} \mathrm{~W}$ kategoriach modeli DSGE o sztywności nominalnej możemy mówić, gdy dana zmienna nominalna nie może ulegać zmianie równie często co instrumenty polityki pieniężnej. Stąd w przypadku prezentowanego modelu sztywność cen nie występowałaby, gdyby wszystkie przedsiębiorstwa miały możliwość zmienić cenę co kwartał.

${ }^{9}$ Zob. też. dyskusję o zaletach i ograniczeniach prowadzenia analiz ekonomicznych za pomocą sformalizowanych modeli w pracy Dudka (2008, s. 9-10). 
przypadku należy przyjąć, że mają one charakter egzogeniczny ${ }^{10}$. Z kolei wykorzystanie modelu o postaci liniowej (po log-linearyzacji), pozwala uzyskać wyniki (w szczególności kształt funkcji odpowiedzi na impuls) niezależne od wyjściowego poziomu zmiennych ${ }^{11}$.

Jedynym rozszerzeniem podstawowej wersji małej skali modelu DSGE, które wprowadzamy jest wprowadzenie grup gospodarstw domowych oraz przedsiębiorstw nieoptymalizujących, wyznaczających konsumpcję i ceny na podstawie prostych zachowań adaptacyjnych (rule-of-thumb, zob. Amato i Laubach, 2003). Uwzględnienie zachowań adaptacyjnych pozwala na odejście od skrajnie nierealistycznego założenia, że wszystkie podmioty mają racjonalne oczekiwania, na rzecz podejścia hybrydowego (adaptacyjno-racjonalnego). Istnieje wiele powodów tłumaczących brak w pełni racjonalnych oczekiwań podmiotów gospodarczych (bounded rationality). Możemy tu wskazać np. niedoskonałą wiedzę o parametrach gospodarki ${ }^{12}$, koszty gromadzenia i przetwarzania informacji na temat bieżącego stanu gospodarki czy nawet brak dobrej znajomości zasad rządzących gospodarką. Wprowadzenie możliwości, iż przynajmniej część podmiotów wykazuje tego typu „niedoskonałości” wydaje się rozsądnym uogólnieniem podstawowego modelu.

Ponadto równania standardowego modelu zawierały wyłącznie zmienne bieżące lub oczekiwania na jeden okres naprzód wyznaczone według teorii oczekiwań racjonalnych (komponenty antycypacyjne - forward looking). Z tego względu takie równania rzadko uzyskiwały potwierdzenie empiryczne (zob. np.: Gali, Gertler, Lopez-Salido, 2001, 2005; Romer, 2011, s. 344), w przeciwieństwie do modeli hybrydowych. Wymienić można dwa ważne elementy świadczące o przewadze modeli hybrydowych. Po pierwsze - modele takie potrafily odtworzyć tzw. uporczywość inflacji (inflation persistence), czyli występowanie silnego komponentu autoregresyjnego w empirycznych równaniach opisujących inflację (zob. też: Hertel, Leszczyńska, 2013 oraz prace tam cytowane). Po drugie - tzw. „garbatokształtne” odpowiedzi na impuls wynikające z modeli hybrydowych odzwierciedlały stylizowany fakt, jakoby maksymalny efekt polityki pieniężnej występował z opóźnieniem względem zmiany instrumentu tej polityki.

Tak więc w opisywanym modelu występują: gospodarstwa domowe (dwie grupy), przedsiębiorstwa (dwie grupy) oraz bank centralny.

${ }^{10}$ To założenie oczywiście znacznie ogranicza zakres tego typu analiz.

${ }^{11}$ Dla gospodarki Polski zagadnienie to, na zbliżonym do naszego przykładzie transmisji polityki pieniężnej lecz przy użyciu nieliniowego modelu wektorowej autoregresji, przedstawia praca Postka (2011).

${ }^{12}$ Wydaje się, że racjonalne oczekiwania mogą być formułowane bez znajomości parametrów „prawdziwego modelu" - wystarczy bowiem aby oczekiwania (prognozy) formułować na podstawie jego ,postaci zredukowanej”. Argument ten podsunął M. Raczko podczas dyskusji. 
Gospodarstwa domowe konsumują dobra (co przynosi im użyteczność) i świadczą pracę (co zmniejsza ich użyteczność).

Gospodarstwa domowe (grupa I) optymalizują w nieskończonym horyzoncie czasowym, maksymalizując oczekiwaną zdyskontowaną użyteczność ${ }^{13} U(t)$ :

$$
U(t)=E_{t} \sum_{h=0}^{+\infty} \beta^{h}\left(\frac{C_{t+h}^{I} 1-\sigma}{1-\sigma}-\frac{L_{t+h}^{I} 1+\eta}{1+\eta}\right) \underset{C_{t+h}^{I}, L_{t+h}^{I}}{\longrightarrow} \max
$$

gdzie:

$C^{I}$ - wielkość konsumpcji gospodarstwa domowego należącego do grupy I,

$L^{I}$ - ilość pracy świadczonej przez gospodarstwo domowe należące do grupy I,

$\beta$ - współczynnik dyskonta użyteczności,

$\sigma, \eta$ - parametry (odpowiednio: relatywną skłonność do ryzyka, określający jak silnie wygładzoną ścieżkę konsumpcji wybiera gospodarstwo domowe oraz odwrotność współczynnika Frischa ${ }^{14}$, określający relatywną „niechęć do pracy").

Gospodarstwa domowe otrzymują od przedsiębiorstw wynagrodzenie za świadczoną pracę i płacą im za konsumowane dobra. Oszczędności netto (rozumiane jako różnica pomiędzy wartością wynagrodzeń i przychodów z oszczędności netto z poprzedniego okresu a wydatkami konsumpcyjnymi) są lokowane (pożyczane) na jeden okres według stopy procentowej (w pełni kontrolowanej przez bank centralny i ustalanej za pomocą reguły). Jedynym ograniczeniem wiążącym konsumpcję i oszczędności jest ograniczenie budżetowe (brak jest np. ograniczenia co do wielkości depozytów lub kredytów ${ }^{15}$ ), stąd na zasób oszczędności netto wpływ mają wyłącznie bieżące i przeszłe decyzje gospodarstw domowych.

W rezultacie równanie ograniczenia budżetowego ma następującą postać (lewa strona oznacza wydatki, a prawa - przychody):

gdzie:

$$
P_{t} C_{t}^{I}+\frac{1}{1+i_{t}} B_{t}=W_{t} L_{t}^{I}+B_{t-1}
$$

$P_{t}$ - agregatowy poziom cen w gospodarce,

$W_{t}-$ jednostkowa stawka płac,

${ }^{13}$ Zakładamy standardową postać funkcji użyteczności o stałej relatywnej awersji do ryzyka (CRRA - Constant Relative Risk Averse) - zob. np. Romer (2000, s. 59), Dudek (2009, s. 16, 21).

${ }^{14}$ Współczynnik Frischa określa elastyczność podaży pracy względem stawki płac (przy ustalonej wielkości zgromadzonego majątku).

${ }^{15}$ Jedynym ograniczeniem jest ograniczenie co do braku możliwości zadłużania się w nieskończoność (no Ponzi games - „wykluczenie gry Ponziego” - zob. np. Blanchard i Fisher (1993, s. 49-50), a w literaturze polskiej: Mackiewicz, 2010b). 

okresu).

$B_{t}$ - wielkość oszczędności netto gospodarstwa domowego (stan na koniec

Pozostałe gospodarstwa (grupa II, w pracy Amato i Laubacha określana jako rule-of-thumb consumers, co możemy przetłumaczyć jako „podmioty stosujące proste reguły adaptacyjne”), które wyznaczają konsumpcję na poziomie równym produkcji z okresu poprzedniego:

$$
C_{t}^{I I}=Y_{t-1}
$$

gdzie:

$C_{t}^{I I}$ - wielkość konsumpcji gospodarstwa domowego należącego do grupy II, $Y_{t}-$ wielkość produkcji.

W konwencji modelu przyjmuje się ponadto, że gospodarstw adaptacyjnych jest na tyle niedużo, że zachowanie gospodarstw optymalizujących ma niepomijalny wpływ na agregatową konsumpcję. Ponadto każde z gospodarstw domowych co pewien czas zmienia status według podziału na adaptacyjne i optymalizujące (np. losowo $)^{16}$. Ponadto równowaga $\mathrm{w}$ warunkach doskonale konkurencyjnego rynku pracy i giętkich płac wymaga, aby o wielkości świadczonej pracy decydowały wyłącznie przedsiębiorstwa optymalizujące.

Udziały gospodarstw domowych odpowiednio: optymalizujących (grupa I) i adaptacyjnych (grupa II) wynoszą: $(1-\psi)$ i $(\psi)$. Agregacja przebiega za pomocą funkcji Cobba-Douglasa, a zatem agregatowa konsumpcja jest wyrażona jako ważona średnia geometryczna z poziomu konsumpcji poszczególnych typów gospodarstw domowych, co po zlogarytmowaniu stronami prowadzi do następującego równania agregacji:

$$
\ln C_{t}=(1-\psi) \ln C_{t}^{I}+\psi \ln C_{t}^{I I}
$$

gdzie:

$C_{t}$ - wielkość konsumpcji w gospodarce (agregatowa).

Zestawiając warunek optymalnego wyboru gospodarstw domowych z grupy I z zasadą ustalania konsumpcji przez gospodarstwa domowe z grupy II, a następnie łącząc z użyciem (4.4) otrzymujemy równanie opisujące agregatową konsumpcję (zob. Załącznik 4.1).

$$
\ln C_{t}=\gamma \boldsymbol{E}_{\boldsymbol{t}} \ln C_{t+1}+(1-\gamma) \ln C_{t-1}+\sigma_{1}\left(i_{t}-\boldsymbol{E}_{\boldsymbol{t}} \pi_{t+1}\right)
$$

${ }^{16}$ Dzięki temu, przeciętnie rzecz biorąc, spełnione jest ograniczenie budżetowe. 
Ze względu na założenia dotyczące struktury gospodarki (zamknięta, bez udziału państwa i inwestycji), produkcję finalną tworzą wyłącznie wydatki konsumpcyjne $\left(Y_{t}=C_{t}\right)$, co pozwala zapisać analogiczne równanie dla agregatowej produkcji. Równanie to zapisane w kategoriach procentowych odchyleń od równowagi (tj. luki produkcyjnej), określane w literaturze jako tzw. hybrydowa krzywa IS, przedstawia się następująco (zob. Załącznik 4.1, wzór (Z1-8)):

$$
x_{t}=\gamma \boldsymbol{E}_{t} x_{t+1}+(1-\gamma) x_{t-1}+\sigma_{1}\left(i_{t}-\boldsymbol{E}_{t} \pi_{t+1}\right)
$$

Kolejnym rodzajem podmiotów gospodarczych w opisywanym modelu są przedsiębiorstwa. Produkują one dobra wykorzystując jednakową dla wszystkich przedsiębiorstw funkcję produkcji typu Cobba-Douglasa, którą dla reprezentatywnego przedsiębiorstwa możemy zapisać $\mathrm{w}$ postaci ${ }^{17}$ :

$$
Y_{t}(i)=A K^{\alpha} L_{t}(i)^{1-\alpha}
$$

gdzie:

$A, K$ - łączna produktywność czynników produkcji i poziom kapitału (co do których zakładamy, że są stałe),

$L_{t}(i)$ - nakłady pracy zużywane przez dane przedsiębiorstwo w procesie produkcyjnym,

$Y_{t}(i)$ - wielkość produkcji danego przedsiębiorstwa.

Wyprodukowane dobra są sprzedawane na rynku o strukturze konkurencji monopolistycznej. Dzięki takiej strukturze rynku, przedsiębiorstwa są odpowiedzialne za ustalanie cen. Ponadto, podobnie jak w przypadku gospodarstw domowych, wyróżniamy grupy przedsiębiorstw - optymalizujące i korzystające z prostej reguły adaptacyjnej (tj. indeksacji cen; mechanizm taki został zaproponowany przez Galego i Gertlera, 1999).

Ważnym elementem tego modelu jest występowanie sztywności cen. W modelu zakłada się losową sztywność cen typu Calvo ${ }^{18}$, co oznacza że wszystkie

${ }^{17}$ Taka postać agregatowej funkcji pomija zróżnicowanie cen produktów poszczególnych przedsiębiorstw, wynikające ze sztywności nominalnej (zob. Baranowski, Górajski, Malaczewski, 2013). Składnik ten pomijamy, gdyż nie dysponujemy danymi statystycznymi pozwalającymi na jego pomiar lub oszacowanie, a co za tym idzie taka postać nie mogła by zostać wykorzystana do estymacji.

${ }^{18}$ Założenie takie jest oczywiście wysoce kontrowersyjne, bowiem w takim ujęciu sztywności nominalnych możliwość zmiany ceny jest czysto losowa. Mimo że tego typu „loteria” nie występuje w rzeczywistych problemach wyboru ceny przez przedsiębiorstwa, taki prosty mechanizm może stanowić dobre przybliżenie rzeczywiście występujących sztywności cen na poziomie makroekonomicznym gdy częstotliwość zmiany cen nie różni się i nie ulega większym zmianom w czasie. 
przedsiębiorstwa mogą zmienić cenę ze stałym w czasie i jednakowym dla wszystkich firm prawdopodobieństwem $(1-\theta)$.

Różnice pomiędzy firmami dotyczą sposobu ustalania nowo wyznaczanej ceny (w przypadku gdy nie wystąpi bariera sztywności nominalnej).

Pierwsza grupa - przedsiębiorstwa optymalizujące - wyznacza cenę $P_{t}^{I}(i)$, która zapewnia maksymalizację zysku w nieskończonym horyzoncie czasowym. Maksymalizacja dotyczy zdyskontowanego zysku (w nieskończonym horyzoncie czasowym) oraz jest warunkowa ze względu na wystąpienie sztywności nominalnej w przyszłości. Dzieje się tak, gdyż w przyszłości aktualnie wyznaczana cena może ulec zmianie i wówczas przedsiębiorstwo rozwiąże problem ustalania ceny na nowo (a wówczas wcześniej wyznaczona cena nie będzie wpływać na zyski w kolejnych okresach). Stąd, zagadnienie maksymalizacji określone jak wyżej wyraża się formułą (4.8):

$$
Z(t)=E_{t} \sum_{h=0}^{+\infty} S D F_{t, t+h} \theta^{h}\left(P_{t}^{I}(i) Y_{t+h}(i)-T C\left(Y_{t+h}(i)\right)\right) \underset{P_{t+h}^{I}, Y_{t+h}}{\longrightarrow} \max
$$

gdzie:

$S D F_{t, t+h}$ - stochastyczny czynnik dyskontujący strumienie zmiennych nominalnych w okresie $t+h$ w stosunku do okresu $t$,

$\theta$ - prawdopodobieństwo Calvo,

$P_{t}^{I}(i)$ - cena dobra wytwarzanego przez przedsiębiorstwo typu I,

TC $(\cdot)$ - funkcja kosztów całkowitych.

Maksymalizacja przebiega warunkowo względem równania popytu, które opisane jest za pomocą funkcji o stałej elastyczności cenowej $(-\tau)$ :

$$
Y_{t}(i)=\left(P_{t}(i) / P_{t}\right)^{-\tau} Y_{t}
$$

Pozostałe przedsiębiorstwa (adaptacyjne - backward looking) wyznaczają ceny poprzez automatyczną indeksację względem poziomu odniesienia (przeszłego agregatowego poziomu cen). Podczas indeksacji przedsiębiorstwa grupy II stosują wyłącznie przeszłą inflację, lecz uwzględniają przeciętny oczekiwany czas trwania ceny (który wynosi $1 /(1-\theta)$ ). Sprawia to, że nowo wyznaczona cena jest indeksowana niejako „z zapasem”, dzięki czemu przedsiębiorstwa adaptacyjne nie różnią się, co do wartości oczekiwanej, poziomem cen od pozostałych przedsiębiorstw (mimo że indeksacja nie następuje w każdym okresie, lecz losowo, z prawdopodobieństwem $(1-\theta))$.

$$
P_{t}^{I I}=\left(1+\pi_{t-1}\right)^{(1 / 1-\theta)} P_{t-1}
$$

Podobnie jak w przypadku gospodarstw domowych przyjmuje się, że przedsiębiorstwa adaptacyjne nie „dominują” wielkości agregatowych oraz 
że co pewien czas przedsiębiorstwo zmienia status według podziału na adaptacyjne i optymalizujące.

Udziały przedsiębiorstw odpowiednio: optymalizujących (grupa I) i adaptacyjnych (grupa II) wynoszą: $(1-\omega)$ i $(\omega)$. Agregacja inflacji przebiega za pomocą średniej ważonej ze zmian cen z firm typu I i II (gdzie wagi są równe ich udziałom pomnożonym przez prawdopodobieństwo niewystąpienia sztywności nominalnej $\left.{ }^{19}\right)$ :

$$
\pi_{t}=(1-\omega)(1-\theta)\left(\ln P_{t}^{I}-\ln P_{t-1}\right)+\omega(1-\theta)\left(\ln P_{t}^{I I}-\ln P_{t-1}\right)
$$

Podstawienie do równania (4.11) mechanizmu opisującego zmianę cen firm indeksujących (4.10), daje wyrażenie:

$$
\pi_{t}=(1-\omega)(1-\theta)\left(\ln P_{t}^{I}-\ln P_{t-1}\right)+\omega \pi_{t-1}
$$

W celu wyprowadzenia równania inflacji, należy rozwiązać problem optymalizacji zysku przedsiębiorstw optymalizujących, a następnie zestawić otrzymaną zmianę ceny $\mathrm{w}$ tej grupie $\mathrm{z}$ zachowaniem przedsiębiorstw adaptacyjnych. W kolejnym kroku należy wprowadzić zależność łączącą produkcję z realnym kosztem krańcowym. Ostateczna postać równania zwana jest hybrydową nowokeynesistowską krzywą Phillipsa i przedstawia się następująco (zob. Załącznik 4.2, wzór (Z2-18)):

$$
\pi_{t}=\beta_{f} E_{t} \pi_{t+1}+\beta_{b} \pi_{t-1}+\kappa x_{t}
$$

Zachowanie banku centralnego opisuje reguła stóp procentowych. Działalność banku centralnego zapewnia stabilność równowagi (determinacy). W niniejszym opracowaniu przyjmiemy trzy warianty reguły stóp procentowych opartych na koncepcji reguły Taylora, które zostały zweryfikowane empirycznie w poprzednim rozdziale.

Warto również dodać, że zbliżone postacie równania hybrydowej IS zapewni wprowadzenie mechanizmu trwałości nawyków (zob. Abel, 1990; Fuhrer, 2000), zgodnie z którym użyteczność z bieżącej konsumpcji kształtowana jest nie tylko przez absolutny poziom konsumpcji, ale także przez relację konsumpcji do poziomu odniesienia: przeszłej konsumpcji danego gospodarstwa domowego (wewnętrzna trwałość nawyków, internal habit persistence) bądź przeciętnej wszystkich gospodarstw domowych z okresu poprzedniego (zewnętrzna trwałość nawyków, external habit persistence).

Wśród możliwych alternatyw dla równania hybrydowej krzywej Phillipsa z modelu w którym wyróżniono osobną grupę firm nieoptymalizujących zysku możemy wskazać:

\footnotetext{
${ }^{19}$ Przypomnijmy, że $\theta$ spośród wszystkich przedsiębiorstw nie zmienia ceny.
} 
- założenie, że przedsiębiorstwa które w danym okresie nie mogą zmienić ceny dokonają częściowej indeksacji (Christiano, Eichenbaum, Evans, 2005),

- wielosektorowy model z mechanizmem cenotwórczym Taylora, tj. gdy zmiany cen następują w regularnych odstępach czasu (Dixon, Kara, 2005).

Jeszcze bardziej rozbudowaną dynamikę krzywej Phillipsa zapewni odejście od losowej aktualizacji cen na rzecz podejścia opartego o koszty menu, z endogeniczną częstotliwością zmiany cen (state-dependent pricing) lub sztywnością informacji (sticky information). Dla gospodarki Polski modele takie szacowali Górajski i Szafrański oraz Szafrański (w: Baranowski i in., 2013) - mimo znacznych komplikacji formalnych dają one zbliżone wyniki w przypadku analizy reakcji gospodarki na szok polityki pieniężnej.

\section{Dane i wyniki estymacji}

Do estymacji użyto danych kwartalnych dla Polski z okresu I kw. 1997 do III kw. 2012:

$\pi_{t}$ - kwartalna stopa inflacja CPI (liczona w stosunku do poprzedniego kwartału), oczyszczona z sezonowości (przy pomocy procedury Tramo/Seats);

$x_{t}$ - luka produkcyjna, wyznaczona podobnie jak w poprzednim rozdziale, tj. jako procentowe odchylenie realnego PKB oczyszczonego z sezonowości (przy pomocy procedury Tramo/Seats) od deterministycznego trendu wykładniczego;

$i_{t}$ - stopa procentowa WIBOR 1M (średnia arytmetyczna z notowań o częstotliwości dziennej).

Źródłem wszystkich danych makroekonomicznych był Główny Urząd Statystyczny, z wyjątkiem informacji o stopach procentowych WIBOR, które pochodziły z serwisu Reuters EcoWin.

W szacowanych równaniach przyjęto restrykcję $\beta_{f}+\beta_{b}=1$. Restrykcja ta jest spełniona gdy przyjmiemy współczynnik dyskonta równy 1 (por. wzór (Z2-10) w Załączniku 4.2), co jest wartością zbliżoną do typowo stosowanych ${ }^{20}$, a dodatkowo jej zasadność została statystycznie potwierdzona, za pomocą testu Walda.

Specyfikacja estymowanych równań, opartych na wyprowadzeniach z modelu teoretycznego (tj. (4.6) i (4.13)), przedstawiała się następująco ${ }^{21}$ :

${ }^{20} \mathrm{~W}$ badaniach dla danych kwartalnych zwykle przyjmuje się wartości w granicach 0,98-0,99.

${ }^{21}$ Równania podlegające estymacji zawierają dodatkowo wyraz wolny, ze względu na fakt, iż w analizowanej próbie wartości zmiennych objaśnianych w równowadze (steady-state) mogły być różne od zera. 


$$
\begin{gathered}
\pi_{t}=\beta_{0}+\beta_{f} E_{t} \pi_{t+1}+\left(1-\beta_{f}\right) \pi_{t-1}+\kappa x_{t}+\varepsilon_{t}^{\pi} \\
x_{t}=\gamma_{0}+\gamma E_{t} x_{t+1}+(1-\gamma) x_{t-1}+\sigma_{1}\left(i_{t}-E_{t} \pi_{t+1}\right)+\varepsilon_{t}^{x}
\end{gathered}
$$

gdzie:

$\beta_{0}, \gamma_{0}$ - wyrazy wolne,

$\varepsilon_{t}^{\pi}, \varepsilon_{t}^{x}$-składniki losowe.

Dla obydwu równań przyjęto zbliżony zestaw zmiennych instrumentalnych: opóźnienia zmiennych występujących w równaniu (od jednego do trzech kwartałów w równaniu krzywej Phillipsa oraz od jednego do dwóch kwartałów w dynamicznej IS), opóźniony wskaźnik cen producenta ${ }^{22}$ (o jeden kwartał, $p p i_{t-1}$ ) oraz frakcję odpowiedzi $\mathrm{nr} 2 \mathrm{w}$ ankiecie oczekiwań inflacyjnych IPSOS ${ }^{23}$ $\left(\right.$ ipsos $_{t}$ ). Dodatkowe zmienne instrumentalne ( $\mathrm{tj}$. poza standardowo stosowanymi opóźnieniami zmiennych endogenicznych) zostały dobrane spośród zmiennych o potencjalnie dużych zdolnościach predykcyjnych inflacji postulowanych przez teorię (wskaźnik cen producenta - na podstawie kosztowej teorii inflacji) bądź bezpośrednio wyrażających oczekiwania inflacyjne gospodarstw domowych.

Wyniki estymacji z użyciem estymatora uogólnionej metody momentów $\mathrm{z}$ wielokrotną aktualizacją macierzy wag, przedstawiają się następująco ${ }^{24}$ :

$$
\begin{gathered}
\pi_{t}=0,001+0,610 E_{t}\left(\pi_{t+1}\right)+(1-0,610) \pi_{t-1}+0,112 x_{t} \\
(8,9) \\
J=1,6(p=66,2 \%) \quad K-P=15,4(p=1,9 \%)
\end{gathered}
$$

Zmienne instrumentalne: $\pi_{t-1}, \pi_{t-2}, \pi_{t-3}, x_{t-1}, x_{t-2}, x_{t-2}, p p i_{t-1}, i p s o s 2_{t}$

$$
\begin{gathered}
x_{t}=-10,1+0,483 E_{t} x_{t+1}+(1-0,483) x_{t+1}-0,102\left(i_{t}-E_{t} \pi_{t+1}\right) \\
(12,4) \\
\quad(-3,2) \\
J=5,8(p=45,2 \%) \quad K-P=32,0(p=2,2 \%)
\end{gathered}
$$

${ }^{22}$ Podobnie jak stopę inflacji, skorzystano z szeregu wyrażonego w stosunku do poprzedniego kwartału i oczyszczono z sezonowości przy pomocy procedury Tramo/Seats.

${ }^{23}$ Dane te są publikowane przez NBP - zostały zaczerpnięte ze strony www.nbp.pl/home. aspx?f=/statystyka/oczekiwania/oczekiwania.html.

${ }^{24}$ Pod oszacowaniami parametrów znajdują się statystyki $t$-Studenta, obliczone na podstawie błędów szacunku parametrów odpornych na heteroskedastyczność i autokorelację (tzw. estymator HAC). $J$ i $K$-P oznaczają statystyki odpowiednio: testu J (Hansena) i testu Kleibergena-Paap. Obok statystyk testowych, w nawiasach podano empiryczny poziom istotności. 


\section{Zmienne instrumentalne: $\pi_{t-1}, \pi_{t-2}, x_{t-1}, x_{t-2}, i_{t-1}, i_{t-2}, p p i_{t-1}, i p s o s{ }_{t}$}

Oszacowania parametrów strukturalnych posiadają znaki zgodne $\mathrm{z}$ teorią ekonomii - wzrost luki produkcyjnej dodatnio wpływa na inflację, zaś realnej oczekiwanej stopy procentowej ujemnie wpływa na produkcję. Oszacowane parametry związane z oczekiwaniami inflacji (w równaniu krzywej Phillipsa) i luki produkcyjnej (w krzywej IS) zawarte są w przedziale $<0,1>$.

$\mathrm{Na}$ przyjętym $5 \%$ poziomie istotności wszystkie oszacowane parametry są istotne statystycznie, z wyjątkiem $\kappa$ (którego istotność można potwierdzić na poziomie istotności co najmniej 6\%). Instrumenty są dobrane poprawnie - w teście $J$ (Hansena) nie ma podstaw do odrzucenia hipotezy zerowej mówiącej, że przyjęte warunki ortogonalności są spełnione, natomiast $w$ teście Kleibergena-Paap odrzucamy hipotezę zerową mówiącą o braku istotnego wpływu instrumentów na endogeniczne zmienne objaśniające.

W równaniu dynamicznej krzywej IS wpływ luki oczekiwanej oraz przeszłej jest porównywalny. Świadczy to o tym, że udział gospodarstw domowych nieoptymalizujących $(\psi)$ jest bliski 1 . Wyliczając $\psi$ na podstawie wzoru $\gamma=\frac{1}{1+\psi}$ (zob. Załącznik 4.1) otrzymalibyśmy nawet wartość powyżej 1 (ok. 1,07). Należy jednak pamiętać, że już niewiele wyższe oszacowania parametru $\gamma$ (dodajmy: leżące wewnątrz 95\% przedziału ufności) prowadziłyby nas do prawidłowych wartości udziału gospodarstw domowych stosujących proste reguły adaptacyjne $-\mathrm{w}$ granicach od ok. 0,8 do 1 . Nie są nam znane szacunki wartości tego parametru dla gospodarki Polski, jednak możemy porównać wartości parametru tzw. trwałości nawyków (pełniącego w małej skali modelach DSGE podobną rolę co udział gospodarstw nieoptymalizujących). Przykładowo Kolasa (2009) i Szafrański (w: Szafrański, Baranowski, 2012), aplikując techniki bayesowskie do różnych modeli dla Polski otrzymali podobny wynik, tzn. wartości mediany lub średniej z rozkładu a posteriori parametru trwałości nawyków zbliżone do jedności'i ${ }^{25}$.

Z kolei w równaniu inflacji oszacowany parametr przy oczekiwanej inflacji jest wyższy niż przy przeszłej inflacji. Rezultat ten pozostaje w zgodzie z badaniem zawierającym międzynarodowe porównanie ocen parametrów nowokeynesistowskiej krzywej Phillipsa (Benati, 2008), które wskazuje, że w krajach stosujących strategię bezpośredniego celu inflacyjnego (którą to strategię Narodowy Bank Polski stosuje od 1999 roku) parametr przy opóźnionej inflacji jest bardzo niski² ${ }^{26}$.

${ }^{25}$ Dodajmy, że w podejściu bayesowskim przyjmuje się zwykle rozkłady a priori, które przypisują zerowe prawdopodobieństwo wartościom nieinterpretowalnym ekonomicznie (tu: leżącym poza przedziałem $<0,1>$ ). W szczególności wyklucza się wartości parametru trwałości nawyków powyżej jedności.

${ }^{26} \mathrm{Z}$ tego względu uznaje on wręcz, iż w takich krajach należy raczej stosować standardową nowokeynesistowską ( $\mathrm{tj}$. całkowicie forward looking) krzywą Phillipsa niż hybrydową krzywą Phillipsa. Jednakże wyniki naszych badań empirycznych dla Polski wskazują, że postulat ten jest zbyt daleko idący, jako że nie udało się uzyskać akceptowalnych ekonomicznie wyników. 
Przyjmując w ślad za badaniami dla gospodarki Polski (Jankiewicz, Kołodziejczyk, 2008; Wallusch, 2012), że przeciętny okres trwania ceny wynosi ok. trzech kwartałów, można przyjąć, że prawdopodobieństwo niezmienienia przez pojedyncze przedsiębiorstwo ceny w danym kwartale $(\theta)$ wynosi ok. $2 / 3$. W takim przypadku otrzymane oszacowanie parametru $\beta_{F}=0,610$ wskazywałyby, iż ok. $60 \%$ przedsiębiorstw ustala ceny optymalizując, zaś ok. $40 \%$ - korzysta wyłącznie z prostej reguły adaptacyjnej (indeksacji).

Wcześniejsze szacunki dla Polski (za pomocą innych metod estymacji), również potwierdzały nieco wyższą wrażliwość inflacji na lukę produkcyjną (parametr rzędu 0,05 do 0,1) (zob. Fic i in., 2005; Vasicek, 2009). Również na zbliżonym poziomie kształtują się wyniki parametru przy luce produkcyjnej w hybrydowej krzywej Phillipsa $(\kappa)$ dla strefy euro - średnia z wyników 9 badań cytowanych przez Moonsa i in. (2007, tab. 1) wynosi ok. 0,08.

Podkreślmy raz jeszcze, że wyniki analiz małej skali modelu DSGE mogą się różnić w zależności od metody estymacji. W przypadku badania reakcji gospodarki Polski na szok polityki pieniężnej pokazaliśmy to wspólnie z Szafrańskim (2012), porównując przypadek uogólnionej metody momentów i technik bayesowskich. W tamtym badaniu stwierdziliśmy w szczególności, że dla metod bayesowskich efekty szoku polityki pieniężnej wygasają szybciej niż w przypadku metody GMM (zob. Baranowski, Szafrański, 2012). W niniejszej pracy problem ten nie wydaje się kluczowy. Po pierwsze, każda z metod estymacji ma swoje wady i zalety. Trudno jednoznacznie określić która metoda daje wyniki bliższe nieznanej, „prawdziwej” reakcji gospodarki. Po drugie, koncentrujemy się tu na analizie porównawczej trzech wariantów reguł polityki pieniężnej, a jak wynika z wyników uzyskanych w omawianym badaniu, różnice w ocenach parametrów i wynikach estymacji są mniejsze niż w pozostałych równaniach modelu (tamże, np. tab. 4).

\section{Badanie stabilności parametrów}

W celu dodatkowej weryfikacji otrzymanych wyników przeprowadzono analizę stabilności ocen parametrów w czasie. W tym celu wyznaczono oszacowania parametrów za pomocą regresji kroczącej, na podstawie rozszerzających się podprób (recursive sample). Rezultaty przedstawione zostały na wykresach 14 do 17 (pogrubioną linią ciągłą oznaczono punktowe oszacowanie parametru, zaś cienkie linie wyznaczają $95 \%$ przedziały ufności parametru aproksymowane jako oszacowanie parametru \pm 2 średnie błędy jego szacunku). 


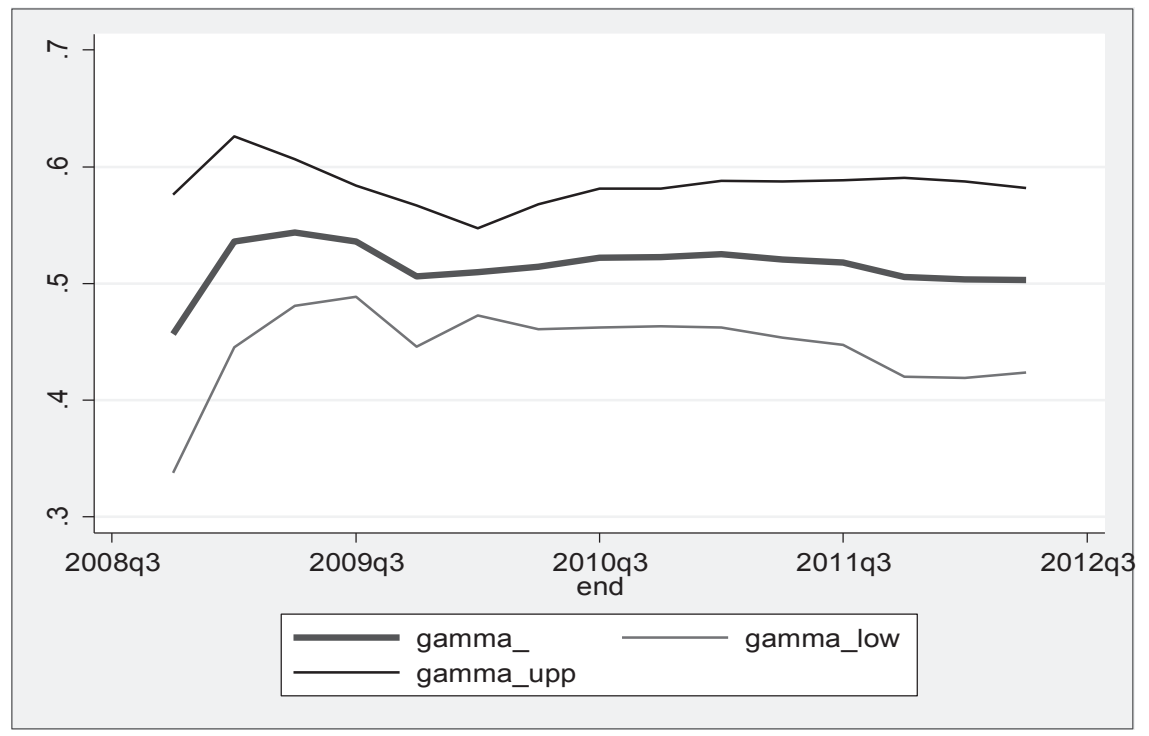

Wykres 14. Oszacowania parametru $\gamma$ (na osi poziomej koniec próby) Źródło: obliczenia własne (dotyczy wszystkich wykresów w rozdz. 4)

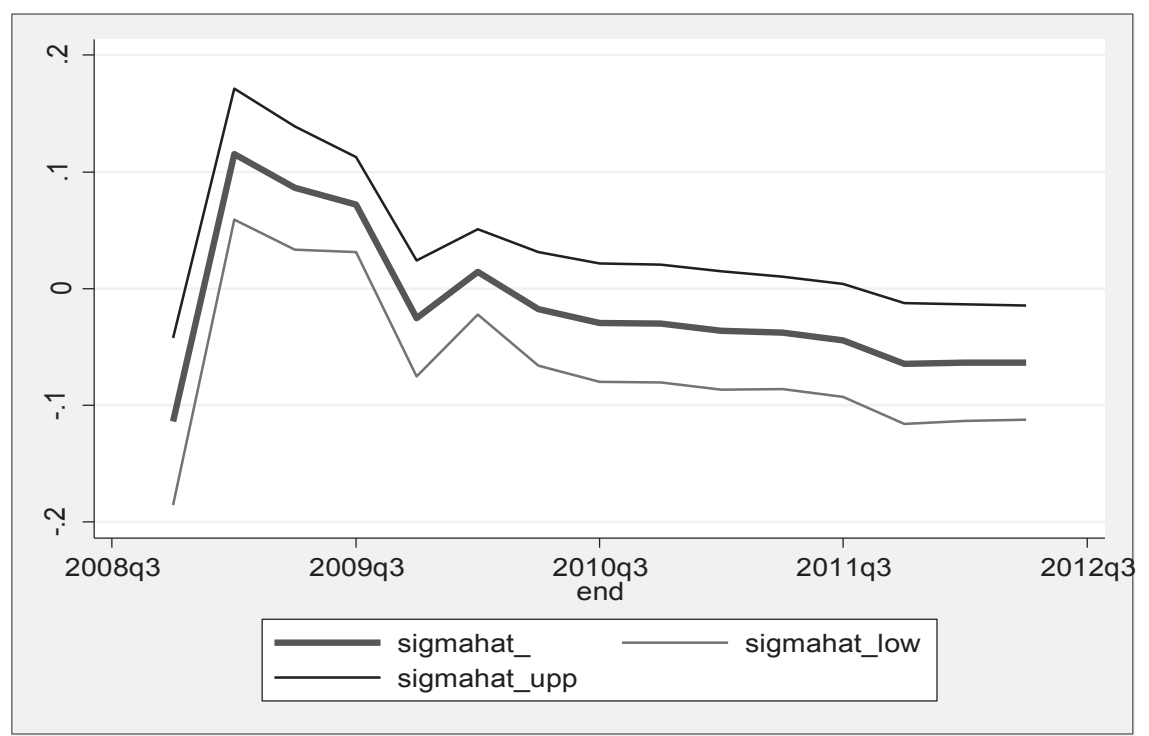

Wykres 15. Oszacowania parametru $\sigma_{1}$ (na osi poziomej koniec próby) 


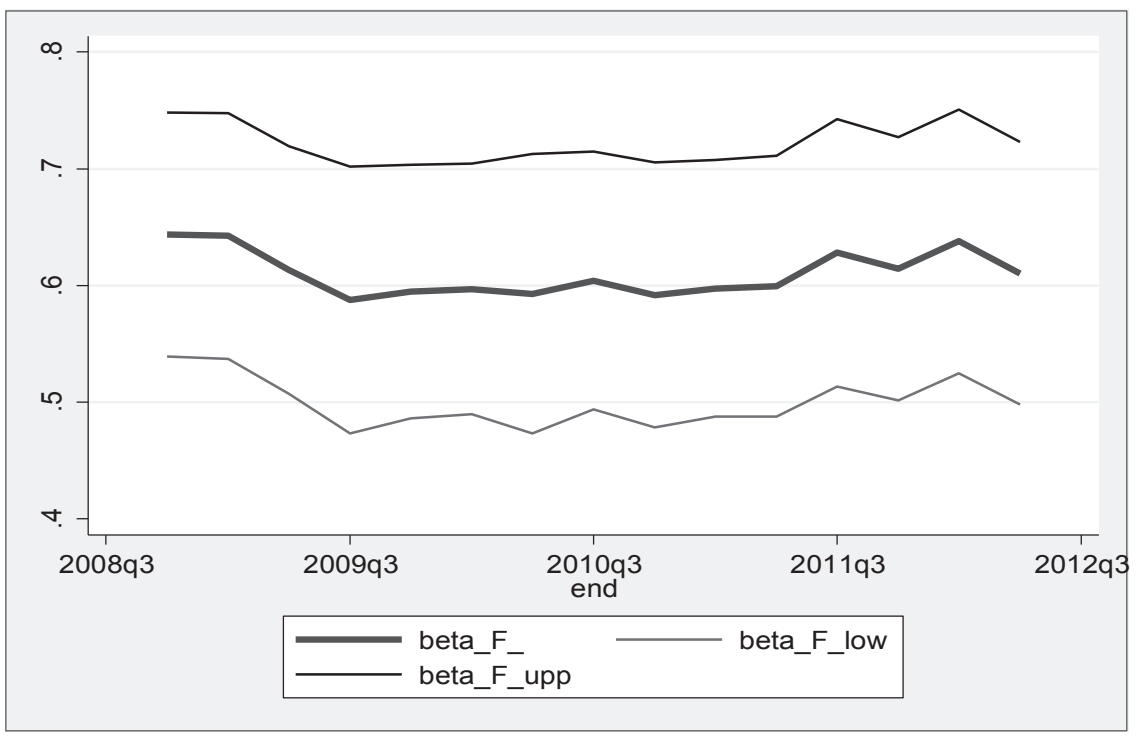

Wykres 16. Oszacowania parametru $\beta_{f}$ (na osi poziomej koniec próby)

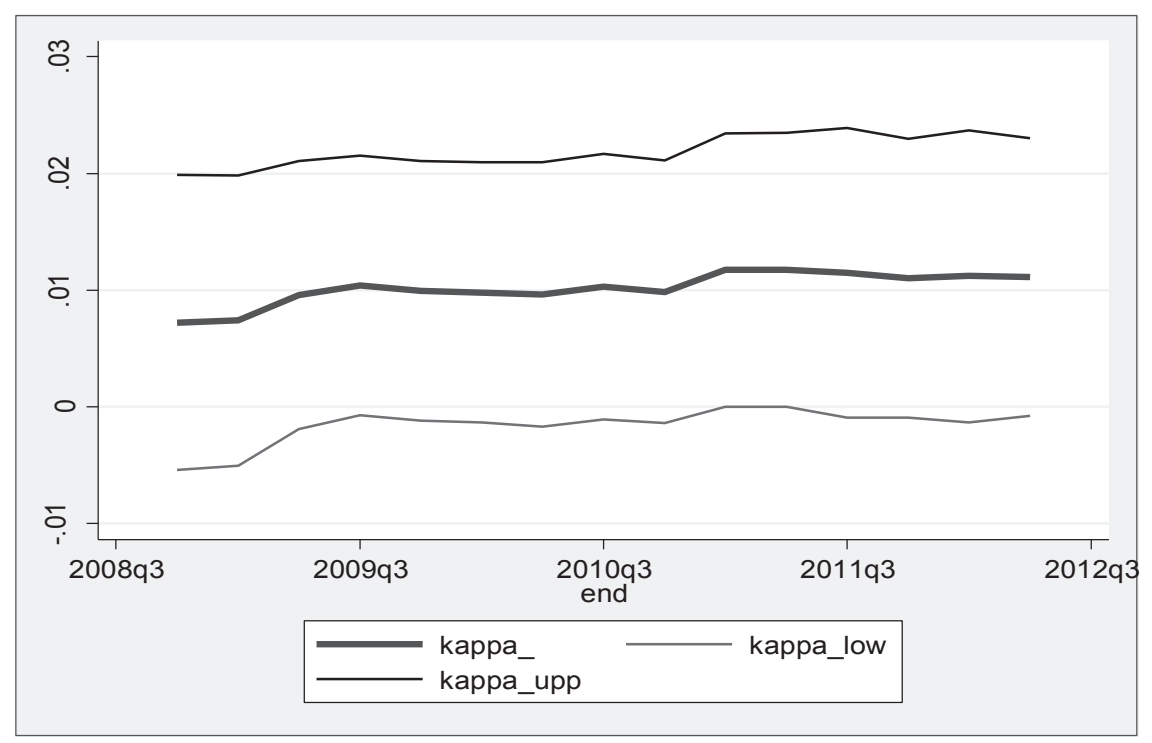

Wykres 17. Oszacowania parametru $\kappa$ (na osi poziomej koniec próby)

Powyższe wyniki pozwalają przyjąć, że parametry $\beta_{f}, \kappa \mathrm{i} \gamma$ były stosunkowo stabilne. W szczególności nie występują silne, jednokierunkowe zmiany 
oszacowań otrzymanych na podstawie kolejnych rozszerzających się prób. Przedziały ufności ocen parametrów $\beta_{f}$ i $\gamma$ nie obejmują zera, co potwierdza ich statystyczną istotność (przy 5-procentowym poziomie istotności). Pomimo bardzo stabilnych punktowych ocen parametru $\kappa$ dla prób rozszerzających się, parametr ten był oszacowany mniej precyzyjnie i jego statystyczna istotność mogłaby zostać potwierdzona przy nieco mniejszym poziomie istotności (podobnie jak dla estymacji na pełnej próbie). W przypadku parametru $\sigma_{1}$ wahania były dość znaczne i np. dla prób kończących się w 2009 roku oceny punktowe były niepoprawne ekonomicznie - dodatnie (choć przy niewielkiej precyzji szacunku tego parametru). Samo porównanie szacunków dla różnych podprób nie pozwala jednoznacznie wyjaśnić przyczyny zmian ocen punktowych, charakterystyczne jest jednak, że takie zmiany nastąpiły wraz z dołączeniem do próby obserwacji z początku kryzysu finansowego.

\section{Rozwiązanie modelu i założenia symulacji - uwagi ogólne}

Nasze dotychczasowe analizy uwzględniały fakt, że w równaniach krzywej Phillipsa i dynamicznej IS inflacja stanowiła wzrost cen w danym kwartale (dlatego zastosowano tam inflację kwartał do poprzedniego kwartału). Natomiast cel inflacyjny jest wyrażony za pomocą inflacji mierzonej w stosunku do analogicznego okresu roku poprzedniego. Mając to na uwadze, w badaniach opisywanych w rozdziale 3 , w regule polityki pieniężnej zastosowano odchylenie inflacji w ujęciu kwartał do analogicznego kwartału roku poprzedniego od celu. W celu połączenia tych równań niezbędne jest wprowadzenie tożsamości (dla uproszczenia przyjęto liniowe przybliżenie).

Pozostałe równania modelu stanowią: krzywa IS, krzywa Phillipsa a także reguły polityki pieniężnej, dla których przyjmujemy punktowe oszacowania parametrów z przeprowadzonych wcześniej estymacji.

Uwzględniając powyższe, pełny model składał się z następujących równań:

$$
\begin{array}{ll}
\pi_{t}=0,610 E_{t} \pi_{t+1}+0,390 \pi_{t-1}+0,112 x_{t} & \text { Hybrydowa krzywa } \\
x_{t}=0,483 E_{t} x_{t+1}+0,517 x_{t-1}-0,102\left(0,25 i_{t}-E_{t} \pi_{t+1}\right) & \text { Hybrydowa IS } \\
i_{t}=\ldots & \text { Reguła polityki pienięż- } \\
\tilde{\pi}_{t}=\pi_{t}+\pi_{t-1}+\pi_{t-2}+\pi_{t-3} & \text { nej (różne warianty) } \\
& \text { Tożsamość inflacji } \mathrm{r} / \mathrm{r}
\end{array}
$$

Ze względu na istniejące dynamiczne powiązania pomiędzy zmiennymi endogenicznymi oraz występowanie oczekiwań, bezpośrednia interpretacja 
parametrów strukturalnych nie jest możliwa. Zamiast tego, podobnie jak w pozostałych modelach, w których wszystkie obserwowalne zmienne są endogeniczne (np. w modelach klasy VAR lub SVAR), w dalszych częściach opracowania przeprowadzimy analizę odpowiedzi na impulsowe szoki.

Symulacje przedstawione $\mathrm{w}$ dalszej części pracy przeprowadzono dla różnych wariantów reguły polityki pieniężnej, wywodzących się z propozycji Taylora $^{27}$. Przyjęto zatem trzy postacie reguł, których parametry oszacowano w poprzedniej części pracy (zob. rozdz. 3) uzupełnione o szok polityki pieniężnej $v_{t}$ :

a) reguła adaptacyjna:

$$
i_{t}=0,988 i_{t-1}+0,230 \tilde{\pi}_{t-1}+0,214 \Delta \tilde{\pi}_{t-1}+0,209 \Delta x_{t-1}+v_{t},
$$

b) reguła bieżąca: $i_{t}=0,965 i_{t-1}+0,370 \tilde{\pi}_{t}+0,152 \Delta x_{t}+v_{t}$,

c) reguła antycypacyjna: $i_{t}=0,961 i_{t-1}+0,424 \boldsymbol{E}_{t} \tilde{\pi}_{t+1}+v_{t}$.

W celu analiz przyjętego scenariusza zacieśnienia polityki pieniężnej otrzymano rozwiązanie modelu racjonalnych oczekiwań metodą Andersona i Moore'a ${ }^{28}$. Następnie wyznaczono odpowiedzi na impuls (przedstawione wykresy prezentują zmianę wartości zmiennych w stosunku do ich wyjściowego poziomu).

Dodatnie zaburzenie $v_{t}$ możemy interpretować jako nadzwyczajne, nie wynikające z parametrów gospodarki, zacieśnienie polityki pieniężnej (odejście od reguły polityki pieniężnej). Na potrzeby naszych analiz przyjęto, że szok polityki pieniężnej ma charakter białoszumowy (niezautokorelowany), co jest standardowym rozwiązaniem w przypadku, gdy w regule uwzględniono wygładzanie stóp procentowych (np. Smets i Wouters, 2003, 2007, Adolfson i in., 2005; w modelach dla Polski: Grabek, Kłos, Utzig-Lenarczyk, 2007; Baranowski, Szafrański, 2012). Założenie takie odpowiada brakowi autokorelacji składników losowych w regule adaptacyjnej i bieżącej. Ponadto rozwiązanie takie ułatwia analizę, bowiem nie wymaga estymacji dodatkowego parametru określającego trwałość szoku.

Modele DSGE, w przeciwieństwie do słabiej osadzony w teorii modeli VAR, mają ściśle określoną strukturę a co za tym idzie - można bardziej szczegółowo analizować działanie mechanizmu transmisji polityki pieniężnej. W rozważanym modelu transmisja impulsu monetarnego rozpoczyna się od zmiany alokacji w czasie

${ }^{27} \mathrm{~W}$ każdej z zastosowanych reguł wartości parametrów pozwalają na otrzymanie jednoznacznego rozwiązania racjonalnych oczekiwań modelu DSGE. Problem tzw. „określoności równowagi” (determinacy) przedstawia np. Gali (2008, s. 75-80), a w literaturze polskiej Wallusch $(2011,2013)$. Woodford (2003, s. 252) interpretuje warunek istnienia tak rozumianej jednoznaczności rozwiązania jako długookresową reakcję stopy procentowej na wzrost inflacji co najmniej 1:1, tj. w sposób zbliżony do tzw. zasady Taylora.

${ }^{28}$ Obliczenia wykonano za pomocą procedur stanowiących część pakietu YADA (www.texlips.net/yada/). Odpowiednie procedury do obliczeń napisane w języku programu Matlab udostępnimy na życzenie. 
wydatków konsumpcyjnych. Stopa procentowa stanowi tu bowiem koszt alternatywny odłożenia konsumpcji $\mathrm{w}$ czasie $\mathrm{z}$ okresu $t$ na $t+1$. Na skutek odłożenia przez gospodarstwa domowe części konsumpcji na przyszłość bieżąca produkcja spada, tym samym luka produkcyjna staje się ujemna. W warunkach niższego popytu (bieżącego i oczekiwanego), przedsiębiorstwa które aktualizują cenę, ustalają ją na (ceteris paribus) niższym poziomie. Tym samym następuje spadek inflacji.

Dla rozpatrywanych wariantów reguł polityki pieniężnej, rozpatrzymy dwa scenariusze.

W pierwszym analizowanym scenariuszu zacieśnienie polityki ma charakter nieoczekiwany dla podmiotów gospodarczych, co oznacza że informacja o zacieśnieniu pojawia jednocześnie z jej realizacją (tzn. podmioty dowiadują się o tym w momencie, gdy następuje zmiana stóp procentowych).

W wielu przypadkach trudno jest przyjąć założenie, iż szok nie może zostać przewidziany przez podmioty gospodarcze. Tego typu oczekiwane szoki standardowo występują w przypadku zmian polityki fiskalnej (np. Blanchard, Perotti, 2002) lub innowacji technologicznych (np. Jaimovich, Rebelo, 2010; Barsky, Sims, 2011). Tego rodzaju przewidywalność szoku polityki fiskalnej wynika z opóźnień instytucjonalnych (głównie ze względu na czas trwania procesu legislacyjnego). Także w przypadku szoku technologii, upływa pewien czas zanim nowe rozwiązania technologiczne czy organizacyjne zostaną wdrożone i upowszechnią się. W niemal wszystkich dotychczasowych modelowych analizach polityki pieniężnej zakładano, że szok polityki pieniężnej jest nieoczekiwany. Możliwa jest jednak zapowiedź przyszłego zacieśnienia polityki pieniężnej wypowiedziana wprost przez bank centralny. Choć jak dotąd przedstawiciele Narodowego Banku Polskiego nie wypowiadali się tak stanowczo, co do przyszłej polityki pieniężnej, wydaje się że w niektórych sytuacjach silnie sugerowano serię zmian stóp procentowych. Ograniczając się wyłącznie do wypowiedzi Prezesa NBP z 2012 i pierwszej połowy 2013 roku możemy wskazać następujące wypowiedzi sygnalizujące zmiany stóp:

Rada uznała, że taka jednorazowa obniżka o 50 pkt. jest właściwą odpowiedzią zarówno na projekcję, jak i na chęć, żeby pewną rundę obniżek zakończyć (M. Belka, marzec 2013) ${ }^{29}$.

Widzimy zmianę w podejściu części RPP i pogłębiające się przekonanie, że istnieje przestrzeń

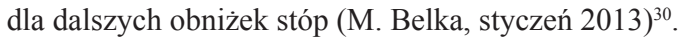

Rada Polityki Pieniężnej poważnie rozważa możliwość podniesienia stóp procentowych i zbliża się do tego kroku bardzo zdecydowanie (M. Belka, kwiecień 2012) ${ }^{31}$.

\footnotetext{
${ }^{29}$ www.forbes.pl/koniec-cyklu-obnizek-stop-procentowych-, artykuly, 143293,1,1.html.

${ }^{30}$ biznes.pl/magazyny/finanse/istnieje-przestrzen-do-dalszych-ciec-stop-procento,5386794, magazyn-detal.html.

${ }^{31}$ www.bankier.pl/wiadomosc/Belka-Rada-Polityki-Pienieznej-powaznie-rozwaza-podniesienie-stop-2514597.html.
} 
Warto dodać, że analiza oczekiwanego zacieśnienia wpisuje się w szerszy nurt dyskusji na temat zakresu komunikacji banku centralnego ${ }^{32}$. Podobne „zapowiedzi" zmiany stóp wystąpiłyby bowiem w przypadku publikacji ścieżki stóp procentowych (zob. Brzoza-Brzezina, 2008, 2011; Leszczyńska, 2012; ZiarkoSiwek 2013) albo oficjalnego „nastawienia” syntetycznie opisującego prawdopodobny kierunek zmian stopy procentowej (Szyszko, 2012). W Polsce „,nastawienie polityki pieniężnej” było ogłaszane przez Radę Polityki Pieniężnej do roku 2005. Jak dotąd nie zdecydowano się na ogłaszanie ścieżki stóp, choć przedstawiciele Narodowego Banku Polskiego deklarowali w latach 2009-2010 prace nad wdrożeniem tego instrumentu (Szyszko, 2012).

Warto jednak podkreślić, że szczegóły działania prezentowanych mechanizmów są nieco inne - w przypadku publikacji ścieżki stóp albo nastawienia zapowiedzi są elementem szeroko rozumianej reguły, zaś w naszym modelu zmiany stóp mają postać egzogenicznego odejścia od reguły (na dodatek „białoszumowego”). Ponadto opublikowana ścieżka stóp procentowych (a tym bardziej „nastawienie"), w przeciwieństwie do ogłoszonego wcześniej zacieśnienia, nie stanowi bezwarunkowego zobowiązania do zmiany stóp.

Przykładem zacieśnienia polityki pieniężnej, które mogłoby zostać poznane z wyprzedzeniem może być zacieśnienie związane z koniecznością spełnienia kryterium inflacyjnego z Maastricht ${ }^{33}$. Wydaje się bowiem, że już samo wejście do Europejskiego Mechanizmu Kursowego ERM2 w pewnym sensie „wzbudzi” oczekiwania na spełnienie kryteriów konwergencji.

Dlatego też $\mathrm{w}$ drugim scenariuszu analizujemy przypadek oczekiwanego odejścia od reguły. Założono, że w momencie $t=0$ bank centralny zapowiada, iż za cztery kwartały nastąpi nadzwyczajne zacieśnienie polityki monetarnej34. Tego typu scenariuszowi odpowiada następujący sposób wprowadzenia szoku do równań reguł ${ }^{35}$ :

d) reguła adaptacyjna:

$$
i_{t}=0,988 i_{t-1}+0,230 \tilde{\pi}_{t-1}+0,214 \Delta \tilde{\pi}_{t-1}+0,209 \Delta x_{t-1}+v_{t-4},
$$

e) reguła bieżąca: $i_{t}=0,965 i_{t-1}+0,370 \tilde{\pi}_{t}+0,152 \Delta x_{t}+v_{t-4}$,

f) reguła antycypacyjna: $i_{t}=0,961 i_{t-1}+0,424 \boldsymbol{E}_{t} \tilde{\pi}_{t+1}+v_{t-4}$.

${ }^{32}$ Kaźmierczak (2008, s. 158) określa takie działania mianem instrumentów „oddziaływania przez perswazję".

${ }^{33} \mathrm{~W}$ ten sposób analizowaliśmy to zagadnienie w: Baranowski (2011a), przy czym tam przyjęliśmy zacieśnienie o umiarkowanym stopniu trwałości (o współczynniku autoregresji szoku na poziomie 0,4$)$.

${ }^{34}$ Tak więc moment zacieśnienia jest z góry znany i nie występuje co do niego niepewność.

${ }^{35} \mathrm{~W}$ podobny sposób szoki oczekiwane wprowadzili Schmitt-Grohe i Uribe $(2009,2012)$. 
W takim scenariuszu możliwe jest zbadanie efektów samej zapowiedzi takiego zacieśnienia (od $t=0$ do $t=3$ ) oraz faktycznych skutków zacieśnienia (począwszy od $t=4$ ). Przyjęcie horyzontu 4 kwartałów nie oznacza, że typowa zapowiedź zmiany polityki występuje z tak długim wyprzedzeniem, a podyktowane jest głównie chęcią lepszego zobrazowania efektu zapowiedzi i faktycznego zacieśnienia.

Warto także odnotować, że na gruncie teoretycznym reakcja gospodarki na zaostrzenie polityki pieniężnej (zwłaszcza oczekiwane) jest silnie uwarunkowana wiarygodnością władz monetarnych (zob. np.: Mackiewicz-Łyziak, 2010) ${ }^{36}$. Przyjmując, że zapowiedź ta jest wiarygodna, oczekujemy że w scenariuszu szoku oczekiwanego reakcja będzie silniejsza niż w przypadku szoku nieoczekiwanego. Do kwestii tych wrócimy w dalszej części opracowania, przy okazji interpretacji wyników symulacji.

W celu zwiększenia czytelności opracowania, początkową wielkość szoku polityki pieniężnej ustalono, tak aby odpowiadała wzrostowi stopy procentowej o 0,5 p. proc. $\mathrm{w}$ momencie wystąpienia szoku ( $\mathrm{tj} . t=0$ dla szoku nieoczekiwanego oraz $t=4$ dla szoku oczekiwanego w horyzoncie 4 kwartałów).

Dodatkowo, w celu oceny wrażliwości wyników na zmiany parametrów poszczególnych modelu DSGE przeprowadzono symulację Monte-Carlo (szczegółowy opis symulacji oraz wyniki w Załączniku 4.3). Tam również przedstawiono reakcje inflacji wyrażonej w stosunku do poprzedniego kwartału (które pomijamy w głównej części pracy ze względu na niewielkie znaczenie tak liczonej inflacji w praktyce gospodarczej i czytelność wyników).

\section{Wyniki symulacji - reguła adaptacyjna}

W niniejszej części przedstawiamy dynamikę reakcji na szok polityki pieniężnej $\mathrm{w}$ modelu z regułą adaptacyjną. Na wykresach 18-20 przedstawiono odchylenia zmiennych od wartości w stanie długookresowej równowagi. Linia ciągła prezentuje reakcję na szok nieoczekiwany, linia ze znacznikami - na szok oczekiwany w horyzoncie czterech kwartałów, a na osi poziomej - liczbę kwartałów, jaka upływa od szoku (przy szoku nieoczekiwanym) lub jego zapowiedzi (przy szoku oczekiwanym).

W modelu z regułą adaptacyjną zacieśnienie polityki pieniężnej powoduje spadek produkcji oraz inflacji, zgodnie z przesłankami wynikającymi z teorii ekonomii.

${ }^{36} \mathrm{~W}$ skrajnej sytuacji (pełna wiarygodność i bardzo silny wpływ oczekiwań inflacyjnych na bieżącą inflację) możliwe jest np., że sama zapowiedź zaostrzenia polityki pieniężnej spowoduje spadek inflacji. 


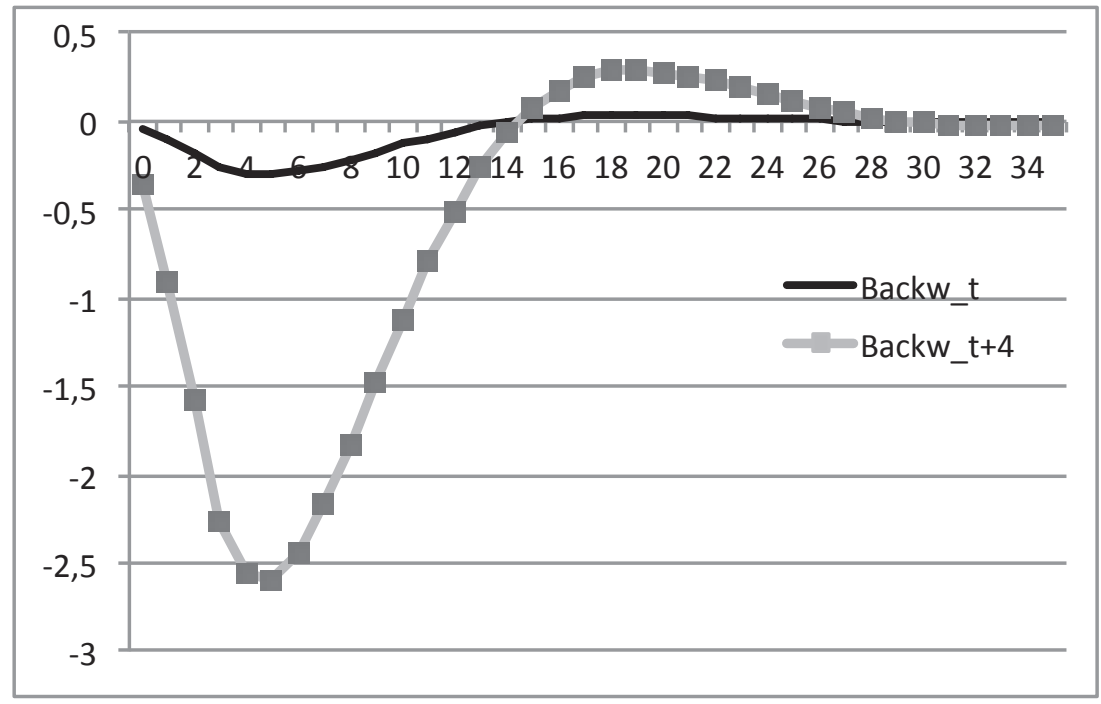

Wykres 18. Reakcja inflacji (r/r) na szok polityki pieniężnej w regule adaptacyjnej

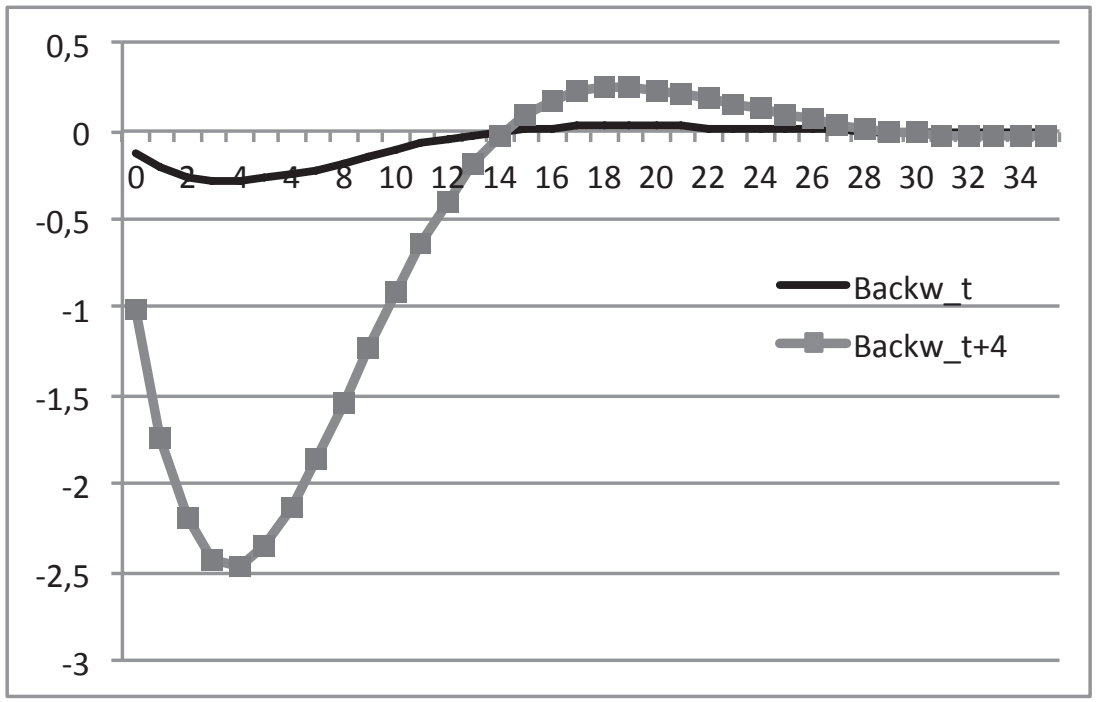

Wykres 19. Reakcja luki produkcyjnej na szok polityki pieniężnej w regule adaptacyjnej 


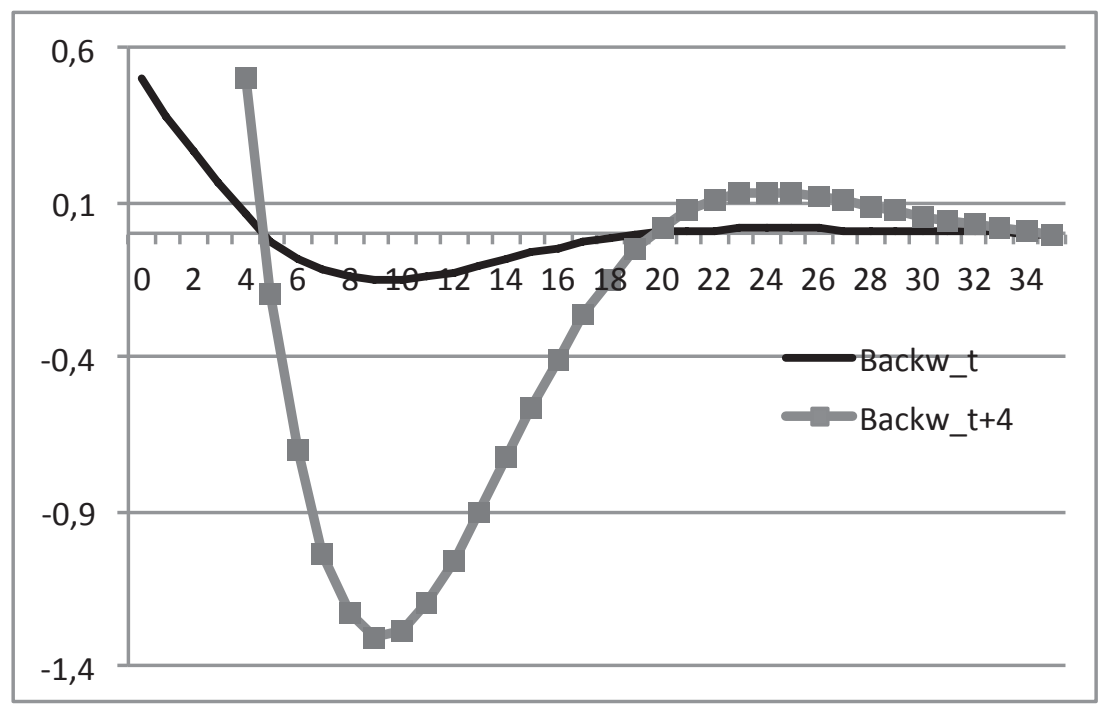

Wykres 20. Reakcja stopy procentowej na szok polityki pieniężnej w regule adaptacyjnej

Maksymalny spadek inflacji (wyrażonej w stosunku do analogicznego kwartału poprzedniego roku, dalej: r/r) i luki produkcyjnej na skutek tego zacieśnienia występuje z opóźnieniem. Taki przebieg dynamiki reakcji, określany niekiedy jako tzw. garbatokształtny ( hump-shaped), odzwierciedla „stylizowany fakt”, zgodnie z którym reakcja na zmiany instrumentów polityki pieniężnej występuje z opóźnieniem.

W przypadku inflacji w scenariuszu szoku nieoczekiwanego maksymalny efekt obserwujemy po upływie pięciu kwartałów od momentu zacieśnienia polityki pieniężnej, zaś w scenariuszu szoku oczekiwanego - po upływie czterech kwartałów od zapowiedzi zacieśnienia (tj. równocześnie z samym wzrostem stopy procentowej).

Z kolei luka produkcyjna osiąga najniższą wartość po upływie czterech kwartałów od momentu zacieśnienia (w scenariuszu szoku nieoczekiwanego) lub czterech kwartałów od zapowiedzi zacieśnienia (w scenariuszu szoku oczekiwanego - tj. równocześnie z samym wzrostem stopy procentowej).

Po upływie 4-5 kwartałów możemy zauważyć stopniowy powrót inflacji i luki do równowagi (z obserwowaną niewielką w stosunku do pierwotnej reakcji, krótkotrwałą ,przeciwną” reakcją inflacji i luki).

Analizując siłę reakcji inflacji i luki produkcyjnej w obu prezentowanych scenariuszach, możemy zauważyć, że w scenariuszu szoku oczekiwanego siła reakcji obu tych zmiennych jest kilkukrotnie większa (maksymalny spadek inflacji $\mathrm{r} / \mathrm{r}$ sięga ok. 2,6 p. proc. w scenariuszu szoku oczekiwanego i ok. 0,3 p. proc. w scenariuszu szoku nieoczekiwanego; dla luki produkcyjnej obserwujemy zbliżone wartości w minimum funkcji odpowiedzi na impuls). 
W obu analizowanych scenariuszach, po początkowym wzroście stopy procentowej obserwujemy reakcję przeciwną (zob. wykres 20), wynikająca z reakcji polityki pieniężnej na obniżenie inflacji oraz luki produkcyjnej. Spadek stopy procentowej w porównaniu z poziomem wyjściowym, widoczny jest po upływie czterech kwartałów - w scenariuszu szoku nieoczekiwanego oraz pięciu kwartałów po jego zapowiedzi - w scenariuszu szoku nieoczekiwanego (tj. jeden kwartał po zacieśnieniu). W scenariuszu szoku oczekiwanego taki spadek jest również znacznie głębszy - sięga nawet ok. 1,3 p. proc. poniżej wyjściowej wartości, czyli jest co do skali niemal trzykrotnie większy co sam wzrost stopy procentowej w wyniku zacieśnienie polityki pieniężnej. Takie kształtowanie się stopy procentowej jest bardzo zaskakujące. Podejrzewamy, że takie gwałtowne zmiany stopy procentowej wynikają z niespójności pomiędzy dynamiką szoku (w pełni antycypowany w horyzoncie czterech kwartałów) a pozostałą częścią reguły (adaptacyjna).

Dodajmy, że we wszystkich modelach w scenariuszu szoku oczekiwanego otrzymana reakcja stopy procentowej przed wystąpieniem szoku (tzn. $t<4$ ) była dość zaskakująca i trudna do interpretacji (spadek stopy procentowej). W praktyce trudno oczekiwać tego rodzaju „niekonsekwencji”, polegającej na tym, iż przed zamierzonym zacieśnieniem stóp procentowych bank centralny będzie obniżał stopy procentowe (mimo iż wynika to $\mathrm{z}$ reguły polityki pieniężnej). $\mathrm{Z}$ tego względu w przypadku reakcji stopy procentowej, omówimy jedynie okres po wprowadzeniu szoku (tzn. począwszy od $t=4$ ). Pełne rozwiązanie tego problemu będzie przedmiotem naszych przyszłych badań.

\section{Wyniki symulacji - reguła bieżąca}

Kolejnym rozpatrzonym wariantem jest model z regułą bieżącą. Na wykresach 21-23 przedstawiamy dynamikę reakcji na szok polityki pieniężnej. Podobnie jak poprzednio, analizujemy odchylenia zmiennych od wartości w stanie długookresowej równowagi - linia ciągła prezentuje reakcję na szok nieoczekiwany, linia ze znacznikami - na szok oczekiwany w horyzoncie czterech kwartałów, a na osi poziomej - liczba kwartałów, jaka upływa od szoku (przy szoku nieoczekiwanym) lub jego zapowiedzi (przy szoku oczekiwanym).

$\mathrm{W}$ modelu z regułą bieżącą zacieśnienie polityki pieniężnej powoduje spadek produkcji oraz inflacji, zgodnie z przesłankami wynikającymi z teorii ekonomii.

Początkowa reakcja inflacji i luki jest niewielka, w szczególności znacznie mniejsza co do wartości bezwzględnej niż w przypadku modelu z regułą adaptacyjną. Podobnie jak w poprzednim modelu, obserwujemy ,garbatokształtne” reakcje na impuls. Maksymalny spadek inflacji (r/r) występuje po upływie 4 kwartałów od wystąpienia szoku (w scenariuszu szoku nieoczekiwanego), zaś 
w scenariuszu szoku oczekiwanego - po upływie 5 kwartałów od jego zapowiedzi (tj. 1 kwartał po wzroście stopy procentowej) (zob. wykres 21).

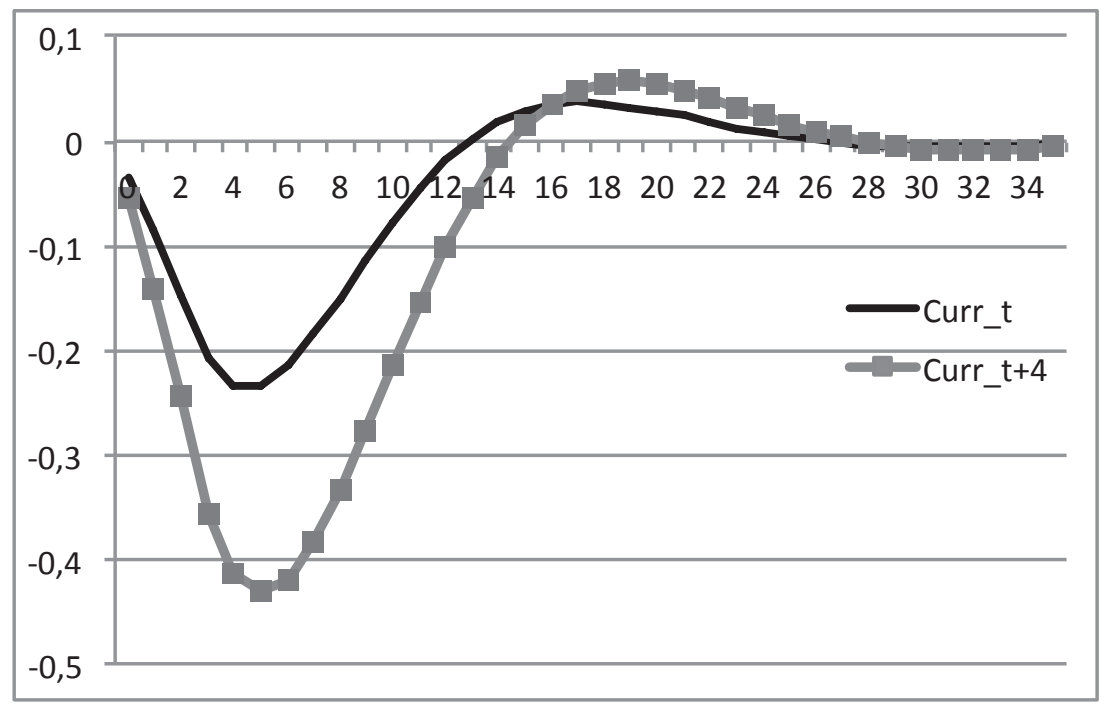

Wykres 21. Reakcja inflacji (r/r) na szok polityki pieniężnej w regule bieżącej

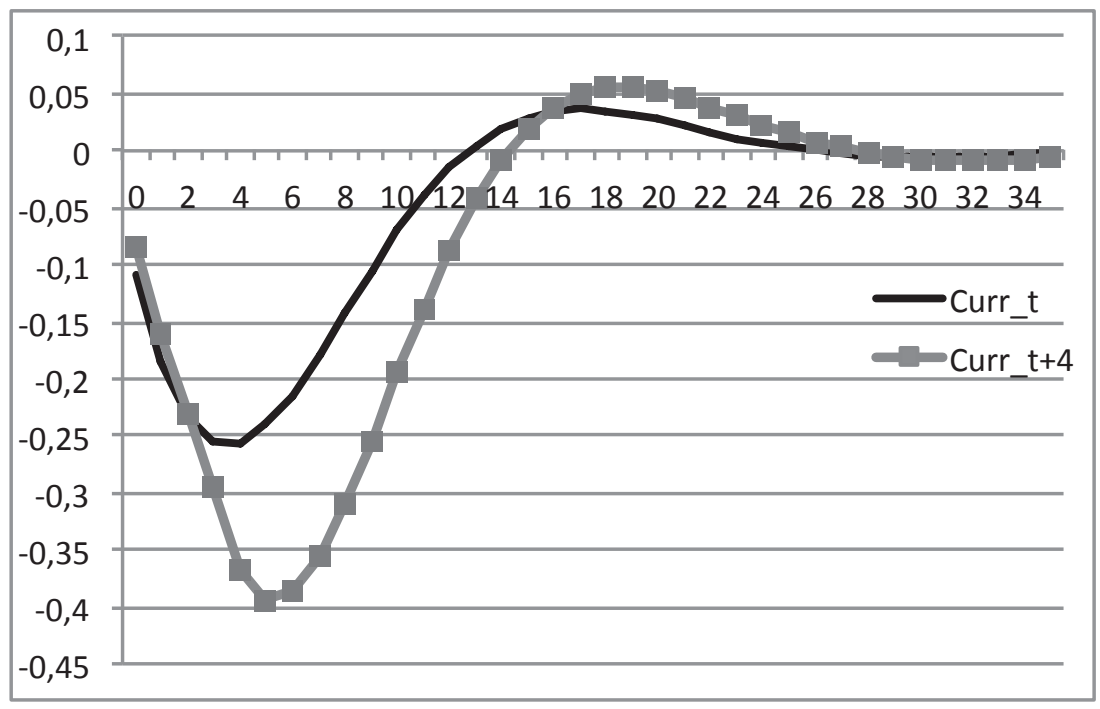

Wykres 22. Reakcja luki produkcyjnej na szok polityki pieniężnej w regule bieżącej 


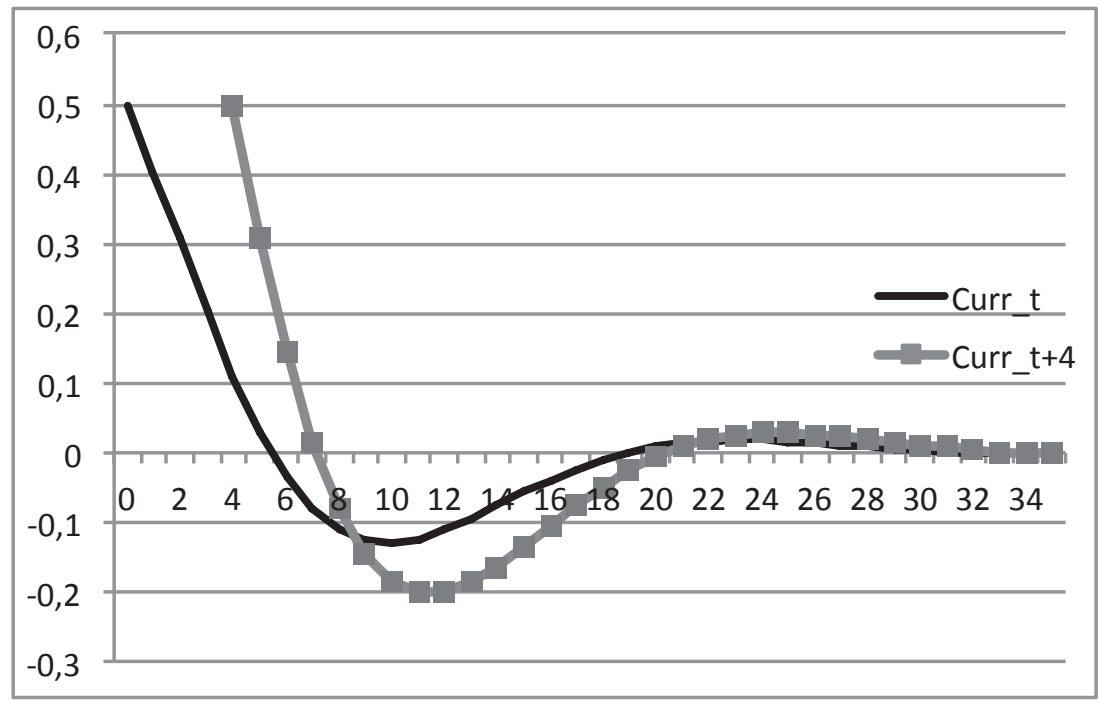

Wykres 23. Reakcja stopy procentowej na szok polityki pieniężnej w regule bieżącej

Zbliżony kształt reakcji obserwujemy w przypadku luki produkcyjnej - tu maksymalny spadek widoczny jest po upływie 3-4 kwartałów od zacieśnienia bądź 5 od jego zapowiedzi, po czym następuje powrót do równowagi.

W scenariuszu zacieśnienia oczekiwanego występuje około dwukrotnie silniejsza reakcja.

$\mathrm{W}$ porównaniu do modelu $\mathrm{z}$ adaptacyjną regułą, przeciwna reakcja wynikająca z dostosowania stopy procentowej do inflacji oraz luki produkcyjnej poniżej równowagi jest słabsza (np. w scenariuszu szoku nieoczekiwanego stopa procentowa spada ok. 0,12 p. proc. poniżej równowagi, podczas gdy w analogicznym scenariuszu dla reguły adaptacyjnej spadek ten był rzędu 0,15 p. proc., a w scenariuszu szoku oczekiwanego różnice były jeszcze większe).

\section{Wyniki symulacji - regula antycypacyjna}

Ostatnim analizowanym przypadkiem jest model z antycypacyjną regułą polityki pieniężnej.

Rezultaty symulacji przedstawiają wykresy 24-26. Linią ciągłą ze znacznikami przedstawiono reakcję zmiennych na szok nieoczekiwany, natomiast linią ciągłą - na szok oczekiwany.

Kształty reakcji inflacji i luki produkcyjnej są poprawne oraz zbliżone do funkcji odpowiedzi na impuls uzyskanych dla reguły bieżącej.

Maksymalny spadek inflacji (r/r) w scenariuszu szoku nieoczekiwanego obserwujemy po upływie 4 kwartałów od momentu zacieśnienia polityki pieniężnej, 
zaś w scenariuszu szoku oczekiwanego - po upływie 4 kwartałów od zapowiedzi zacieśnienia (tj. równocześnie z samym wzrostem stopy procentowej) (zob. wykres 24).

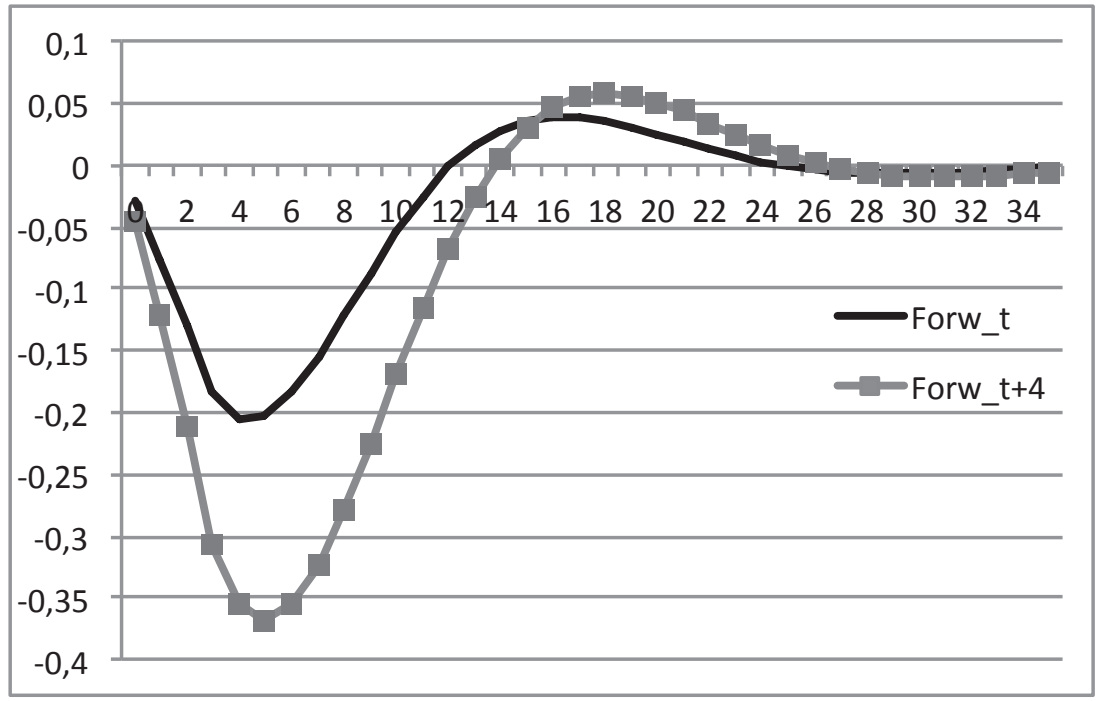

Wykres 24. Reakcja inflacji (r/r) na szok polityki pieniężnej w regule antycypacyjnej

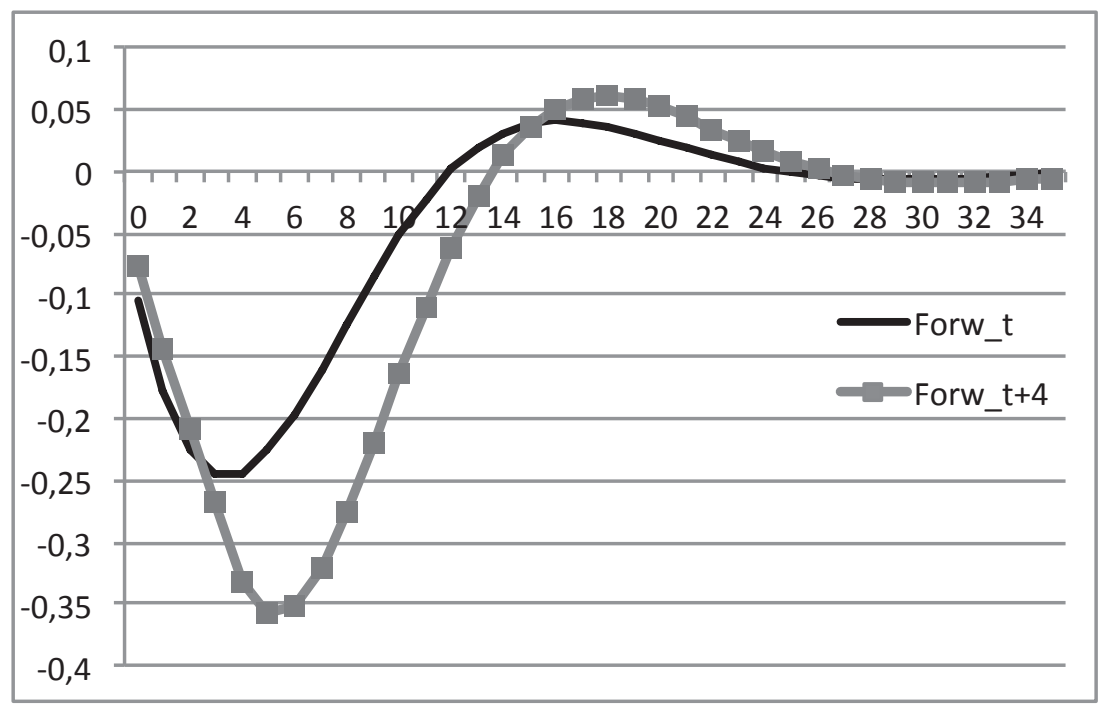

Wykres 25. Reakcja luki produkcyjnej na szok polityki pieniężnej w regule antycypacyjnej 


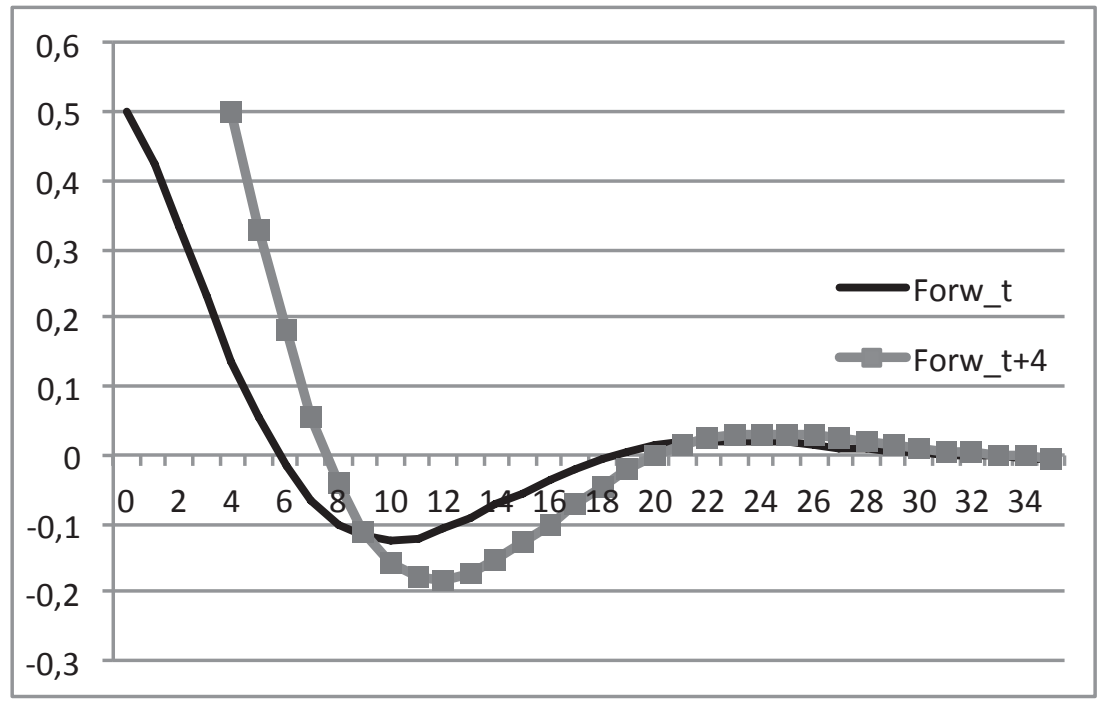

Wykres 26. Reakcja stopy procentowej na szok polityki pieniężnej w regule antycypacyjnej

Z kolei maksymalny spadek luki produkcyjnej następuje po upływie 4 kwartałów od momentu zacieśnienia (w scenariuszu szoku nieoczekiwanego) lub pięciu kwartałów od zapowiedzi zacieśnienia (w scenariuszu szoku oczekiwanego - tj. jeden kwartał po wzroście stopy procentowej) (zob. wykres 25).

Po upływie 4-5 kwartałów możemy zauważyć stopniowy powrót inflacji i luki do równowagi ( $\mathrm{z}$ obserwowaną niewielką w stosunku do pierwotnej reakcji, krótkotrwałą ,przeciwną” reakcją inflacji i luki produkcyjnej).

W scenariuszu szoku nieoczekiwanego reakcja jest niemal dwukrotnie silniejsza (zarówno co do inflacji jak i luki) ${ }^{37}$.

Po początkowym wzroście stopy procentowej po 6-8 kwartałach następuje jej nieznaczny spadek. Podobnie jak w modelu z regułą bieżącą trwa on około roku, a stopa spada poniżej poziomu równowagi maksymalnie o ok. 0,1 p. proc. w scenariuszu szoku nieoczekiwanego i ok. 0,2 p. proc. w scenariuszu szoku oczekiwanego (zob. wykres 26).

\section{Dyskusja i porównanie wyników}

Oszacowanie reakcji zmiennych makroekonomicznych na zacieśnienie polityki pieniężnej (szczególnie nieoczekiwane) jest analizowane z wykorzystaniem

${ }^{37}$ Zauważmy, że dla reguły antycypacyjnej w scenariuszu szoku oczekiwanego, występują równolegle dwa kanały wpływu oczekiwań na stopę procentową: (i) oczekiwany szok oraz (ii) oczekiwania inflacji występujące bezpośrednio w regule. 
innej klasy modeli: np. tradycyjnych wielorównaniowych modeli o równaniach łącznie współzależnych bądź modeli wektorowej autoregresji (VAR). W modelach VAR badacze zaskakująco często otrzymują trudny do interpretacji ekonomicznej wynik, zgodnie z którym występuje krótkotrwały wzrost inflacji na skutek szoku stopy procentowej (tzw. price puzzle) ${ }^{38}$. W analizowanym modelu taki „zagadkowy” wynik nie występuje, co w znacznej mierze wynika z zastosowanego narzędzia ${ }^{39}$. Stosowane przez nas modele klasy DSGE mają ściśle określoną strukturę, a co za tym idzie - działanie mechanizmu transmisji jest zdefiniowane w bardziej jednoznaczny sposób, w przeciwieństwie do standardowych modeli VAR, gdzie teoria ekonomii służy jedynie doborowi zmiennych i określeniu restrykcji co do niektórych bieżących powiązań pomiędzy szokami.

Z perspektywy analiz reguł polityki pieniężnej, ważną kwestią jest nie tylko porównanie reakcji na szok oczekiwany i nieoczekiwane (co przedstawiono w poprzednich częściach rozdziału), ale również porównanie reakcji luki oraz inflacji na zacieśnienie polityki pieniężnej dla trzech analizowanych postaci reguły polityki pieniężnej. Na wykresach 27-28 prezentujemy reakcję inflacji (r/r) i luki produkcyjnej na nieoczekiwany szok polityki pieniężnej (linia ciągła przedstawia reakcję dla reguły bieżącej, linia przerywana - dla reguły adaptacyjnej, linia ze znacznikami - dla reguły antycypacyjnej).

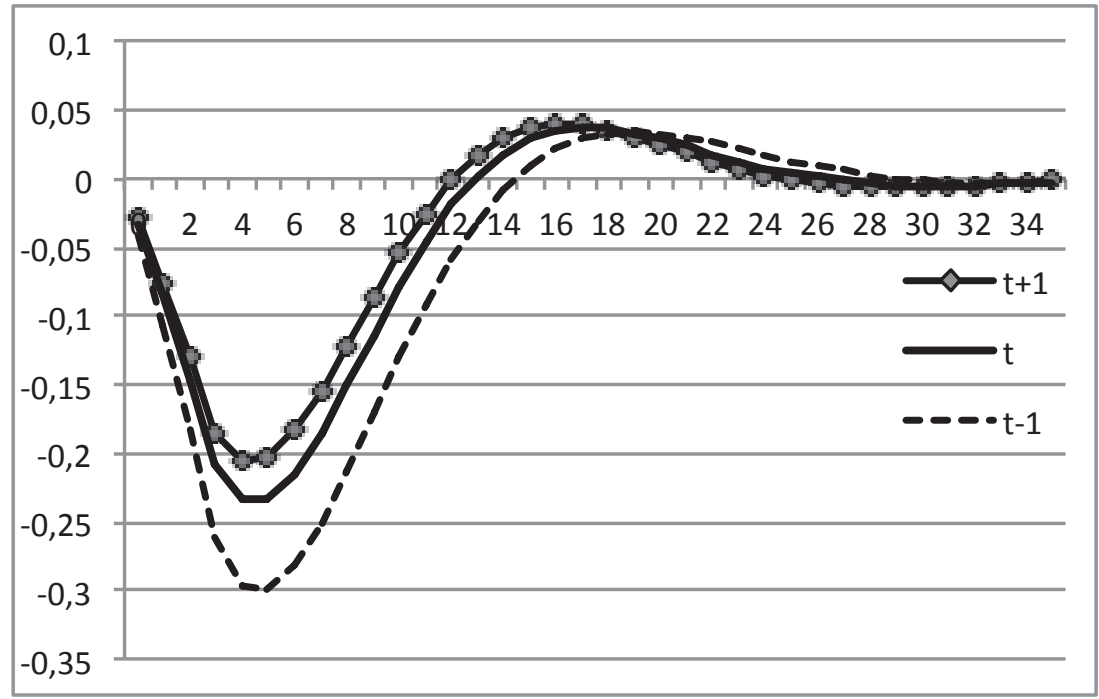

Wykres 27. Reakcja inflacji (r/r) na szok polityki pieniężnej, w zależności od reguły

${ }^{38}$ Nieco szerzej zagadnienie to omawia Kokoszczyński (2004, s. 272).

${ }^{39}$ Wynik taki może jednak występować w modelach DSGE większej skali (por. np. Christiano, Trabandt, Walentin, 2010, rys. 3). 


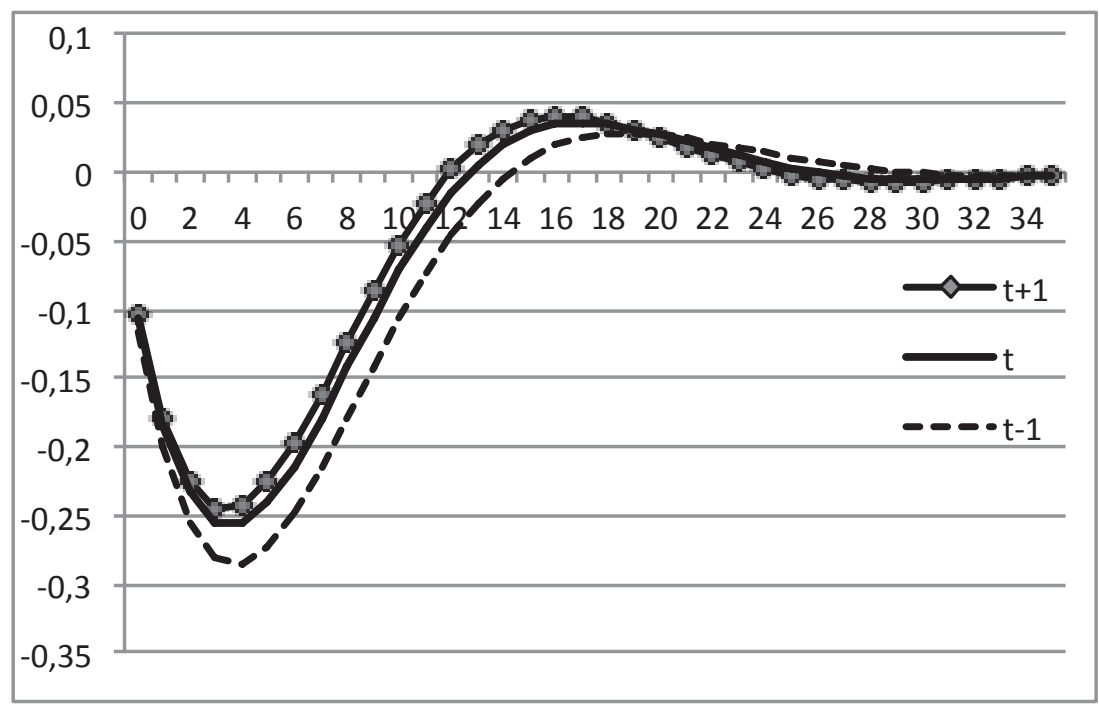

Wykres 28. Reakcja luki produkcyjnej na szok polityki pieniężnej, w zależności od reguły

Na podstawie analizy funkcji reakcji możemy stwierdzić, że ocena reakcji gospodarki Polski na szok polityki pieniężnej widziana przez pryzmat modeli DSGE jest zbliżona, mimo różnic w specyfikacji dynamicznej reguł polityki pieniężnej. Największe różnice możemy dostrzec w przypadku reguły adaptacyjnej, natomiast różnice pomiędzy bieżącą a antycypacyjną są praktycznie niedostrzegalne. Na tej podstawie możemy odrzucić hipotezę nr 4, mówiącą, że skutki szoku polityki pieniężnej dla inflacji i luki produkcyjnej różnią się znacząco, w zależności od przyjętej reguły. Dodajmy, że ze względu na to pominięcie w tym miejscu niepewności co do parametrów (reakcje na impuls zostały wyznaczone na podstawie punktowych ocen parametrów; szersze ujęcie niepewności co do parametrów przedstawiono w Załączniku 4.3), weryfikacja tej hipotezy ma w dużej mierze charakter nieformalny.

Dokonując analogicznego porównania dla scenariusza szoku oczekiwanego możemy stwierdzić, że reakcja inflacji i luki produkcyjnej w modelach z regułą bieżącą i antycypacyjną są zbliżone. Jednak gdy w porównaniu weźmiemy pod uwagę modele $\mathrm{z}$ regułą adaptacyjną, wówczas stwierdzimy znaczne różnice w reakcji (głównie jeśli chodzi o ich skalę).

Oprócz porównania odchyleń inflacji i luki produkcyjnej od poziomów długookresowej równowagi, możemy analizować odchylenia poziomu cen i PKB od poziomu wynikającego ze ścieżek w równowadze, po upływie 35 kwartałów (kiedy możemy mówić o niemal całkowitym wygaśnięciu impulsu) ${ }^{40}$. W tym celu policzymy w tab. 4.1 skumulowane odchylenia od poziomu równowagi, które wcześniej zostały zbiorczo zobrazowane na wykresach 27-28.

${ }^{40}$ Pomysł ten podsunął M. Mackiewicz, podczas dyskusji w trakcie seminarium naukowego. 
Tabela 4.1. Odchylenie poziomu cen i PKB od poziomu równowagi, po 35 kwartałach (w \%)

\begin{tabular}{|c|c|c|c|}
\hline \multirow{2}{*}{ Zmienna } & \multicolumn{3}{|c|}{ Reguła } \\
\cline { 2 - 4 } & adaptacyjna & bieżąca & antycypacyjna \\
\hline Poziom cen & 2,15 & 1,50 & 1,21 \\
\hline PKB & 2,22 & 1,80 & 1,61 \\
\hline
\end{tabular}

Źródło: obliczenia własne (dotyczy tab. 4.1-4.4).

Z obliczeń przedstawionych $\mathrm{w}$ tab. 4.1 wynika, że po krótkookresowym szoku polityki pieniężnej (o sile 0,5 p. proc.), w zależności od reguły, możemy się spodziewać poziomu cen niższego o $1,2 \%-2,2 \%$ a poziomu PKB niższego $1,6 \%-2,2 \%$. Na najsilniejszą reakcję wskazuje model z regułą adaptacyjną, a na najsłabszą - model z regułą antycypacyjną. Dokonując oceny na podstawie tak rozumianej „skumulowanej” reakcji bylibyśmy skłonni niemal dwukrotne różnice pomiędzy odchyleniem poziomu cen $\mathrm{z}$ modelu $\mathrm{z}$ regułą adaptacyjną a $\mathrm{z}$ modelu $\mathrm{z}$ regułą antycypacyjną za znaczące. Różnice odchyleń poziomów PKB są mniejsze i w naszej ocenie można w tym przypadku mówić o podobieństwie wyników.

We wszystkich analizowanych modelach, zarówno w przypadku szoku nieoczekiwanego, jak i oczekiwanego, zacieśnienie polityki pieniężnej generuje spadek inflacji w horyzoncie kilku-kilkunastu kwartałów. Ze względu na krótkookresową wymienność pomiędzy inflacją a aktywnością gospodarczą ${ }^{41}$ punktu widzenia polityki pieniężnej, ważnym pytanie dotyczy kosztów dezinflacji, w zależności od stosowanej reguły polityki pieniężnej i charakteru zacieśnienia (nieoczekiwane/oczekiwane).

Dlatego też warto spojrzeć na wyniki przeprowadzonych analiz przez pryzmat syntetycznej miary kosztów dezinflacji12 jakim jest tzw. współczynnik wyrzeczenia (sacrifice ratio) zaproponowany przez Balla (1994, s. 160-161):

$$
W W=\frac{\sum_{t} x_{t}}{\min \left(\pi_{t}\right)-\max \left(\pi_{t}\right)}
$$

${ }^{41}$ Podzielamy tu zdanie Wojtyny (2004, s. 46), który twierdzi że tezę o krótkookresowej wymienności podzielają przedstawiciele różnych szkół ekonomii. Snowdon, Vane i Wynarczyk, (1998, s. 438) początkowo zajmowali w tej kwestii odmienne stanowisko, cytując wyniki badań wskazujących na wzrost niezgodności co do krótkookresowej krzywej Phillipsa. Snowdon i Vane później jednak przyznali, że krótkookresowa wymienność pomiędzy poziomem aktywności gospodarczej a inflacją jest powszechnie akceptowana (Snowdon, Vane, 2005, s. 704).

${ }^{42}$ Miara ta jest najbardziej popularna, co poszerza krąg odbiorców prezentowanych wyników. Nie oznacza to jednak, że należy traktować współczynnik wyrzeczenia jako jedyną (a tym bardziej wolną od zastrzeżeń) miarę kosztów dezinflacji. Krytykę współczynnika wyrzeczenia w literaturze polskiej prezentuje Wojtyna (2004, s. 56-58). 
Współczynnik wyrzeczenia $(W W)$ mierzy łączny spadek produkcji - mierzony skumulowaną luką produkcyjną w relacji do (maksymalnej) wielkości dezinflacji. Współczynnik ten maleje wraz ze wzrostem wiarygodności, kiedy to dezinflacja może być przeprowadzona w „mniej kosztowny” sposób.

W świetle wcześniejszych analiz dla Polski współczynnik ten, wynosił według szacunków Mackiewicz-Łyziak (2010, s. 132, tab. 4.2):

- 3,1 dla okresu od I kw. 2000 do I kw. 2003,

- 5,4 dla okresu od III kw. 2004 do I kw. 2006, natomiast według szacunków Wróblewskiej (2013):

$-0,2$ dla okresu od II kw. 2000 do I kw. 2003,

- 6,5 dla okresu od IV kw. 2004 do II kw. 2006.

Ze względu na różny sposób liczenia (w naszym badaniu odpowiedzi modelu DSGE na zadany szok polityki pieniężnej, zaś w badaniach Balla i cytowanych autorek bezpośrednio z danych dla okresów dezinflacji), naszym zdaniem wielkości te są nie w pełni porównywalne z cytowanymi wyżej badaniami Mackiewicz -Łyziak (2010) i Wróblewskiej (2013). Ponadto sam pomiar kosztów dezinflacji za pomocą współczynnika wyrzeczenia jest kłopotliwy ze względu na trudności z wyznaczeniem początku i końca okresu dezinflacji oraz niejedoznaczność pomiaru luki produkcyjnej. Problem jest widać wyraźnie na przykładzie cytowanych wyżej szacunków dwu różnych badań, gdzie w zbliżonym okresie zanotowano ok. 15-krotną różnicę współczynników wyrzeczenia ${ }^{43}$.

Należy również podkreślić, że przedstawione w tab. 4.2 wyniki obliczonych współczynników wyrzeczenia powinno się traktować z ostrożnością, gdyż o ile oryginalna propozycja Balla dotyczyła kosztów stosunkowo trwałej dezinflacji, o tyle w prezentowanym modelu inflacja (podobnie jak i inne zmienne) zawsze wraca do stanu długookresowej równowagi.

Współczynniki wyrzeczenia obliczone na podstawie wyników symulacji przedstawionych w poprzednich częściach przedstawiamy w tab. 4.2.

Tabela 4.2. Wartości współczynnika wyrzeczenia dla modeli DSGE z różnymi regułami (scenariusz szoku nieoczekiwanego i oczekiwanego)

\begin{tabular}{|c|c|c|c|}
\hline \multirow{2}{*}{ Scenariusz } & \multicolumn{3}{|c|}{ Reguła } \\
\cline { 2 - 4 } & adaptacyjna & bieżąca & antycypacyjna \\
\hline Szok nieoczekiwany & 7,39 & 7,68 & 7,84 \\
\hline Szok oczekiwany & 7,39 & 6,78 & 6,85 \\
\hline
\end{tabular}

${ }^{43}$ Niekiedy zmiana założeń sprawia nawet, że współczynnik wyrzeczenia zmienia znak na nieprawidłowy ekonomicznie (ujemny). Przykładem mogą być szacunki Mackiewicz-Łyziak dla okresu 2004-2006 wyliczone według zmodyfikowanej metody Balla. 
Współczynniki wyrzeczenia obliczone na podstawie wyników symulacji na modelu DSGE, prezentowanych w niniejszym opracowaniu, mieściły się w granicach od ok. 6,8 do ok. 7,8 .

Identyczny wynik dla scenariusza szoku oczekiwanego i nieoczekiwanego w modelu z regułą adaptacyjną był początkowo dużym zaskoczeniem. Dalsza analiza własności modelu wskazała, że przy regule adaptacyjnej nie wystąpi wzajemna współzależność efektów związanych z samą zapowiedzią i reakcją stopy procentowej na bieżące lub oczekiwane wartości inflacji lub luki produkcyjnej.

Innym narzędziem porównania skuteczności polityki pieniężnej w warunkach różnych reguł może być analiza kwadratowej funkcji straty banku centralnego $^{44}$ (zob. Clarida, Gali, Gertler 1998; Woodford, 2003, rozdz. 6.2) daną wyrażeniem (4.15):

$$
L=\sum_{t}^{\infty} \beta^{t}\left(w_{\pi} \hat{\pi}_{t}^{2}+x_{t}^{2}\right)=w_{\pi} \operatorname{var}\left(\pi_{t}\right)+\operatorname{var}\left(x_{t}\right)
$$

W literaturze spotyka się szereg wskazówek co do wartości wag w funkcji celu (4.15). Formalne sposoby wyznaczania wag wymagają znajomości „głębokich parametrów" (np. Woodford, 2003, s. 400 i n.; Gali, 2008, s. 81-82), podczas gdy w innych pracach przyjmuje się wagi ad hoc (najczęściej zakładając jedynie, że $w_{\pi}>1$, co odzwierciedla przekonanie o relatywnie dużym znaczeniu stabilności cen). Ze względu na fakt, że w przyjętej metodzie estymacji praktycznie niemożliwe jest oszacowanie „głębokich parametrów” przyjęto arbitralnie $w_{\pi}=2$.

Dla analizowanych wcześniej scenariuszy wyznaczono momenty teoretyczne, przy założeniu że szoki są białoszumowe, o zerowej wartości oczekiwanej i wariancjach równej równych wariancji reszt z poszczególnych równańn ${ }^{45}$. $\mathrm{Na}$ tej podstawie wyznaczono wartości wariancji inflacji i luki produkcyjnej generowane przez poszczególne modele ( $\mathrm{w}$ tab. 4.3 dla szoku nieoczekiwanego oraz w tab. 4.4 dla szoku oczekiwanego).

${ }^{44}$ Funkcja ta może zostać wyprowadzona formalnie z mikropodstaw, a tym samym wyrażać utratę ,społecznego dobrobytu” (welfare).

${ }^{45} \mathrm{~W}$ celu umożliwienia porównywalności wyników, założono jednakową wariancję szoku polityki pieniężnej (równą 0,65 , podczas gdy w poszczególnych regułach wariancja reszt wynosiła od 0,62 do 0,68$)$. 
Tabela 4.3. Wariancje teoretyczne i wartości funkcji straty w zależności od reguły (szok nieoczekiwany)

\begin{tabular}{|l|c|c|c|}
\hline \multicolumn{1}{|c|}{ Reguły } & Wariancja inflacji r/r & $\begin{array}{c}\text { Wariancja luki pro- } \\
\text { dukcyjnej }\end{array}$ & $\begin{array}{c}\text { Wartość funkcji } \\
\text { straty }\end{array}$ \\
\hline Reguła adaptacyjna & 5,69 & 7,75 & 14,16 \\
\hline Reguła bieżąca & 4,57 & 7,60 & 11,89 \\
\hline $\begin{array}{l}\text { Reguła antycypa- } \\
\text { cyjna }\end{array}$ & 4,34 & 8,66 & 11,63 \\
\hline
\end{tabular}

Porównanie wartości funkcji straty wskazuje, że najmniej preferowana jest reguła adaptacyjna, zaś najbardziej - reguły antycypacyjnej. Kolejność ta jest przeciwna w stosunku do tej, która wynikała z analizy współczynnika wyrzeczenia (tab. 4.2), lecz jest zgodna z przesłankami teoretycznymi - najlepsze wyniki dla polityki pieniężnej nastawionej na przyszłość. Znacznie bardziej interesujące jest natomiast porównanie funkcji straty w scenariuszach szoku nieoczekiwanego i oczekiwanego. Odpowiednie wyniki dla scenariuszach szoku oczekiwanego przedstawiono $\mathrm{w}$ tab. 4.4 .

Tabela 4.4. Wariancje teoretyczne i wartości funkcji straty w zależności od reguły (szok oczekiwany)

\begin{tabular}{|l|c|c|c|}
\hline \multicolumn{1}{|c|}{ Reguły } & Wariancja inflacji r/r & $\begin{array}{c}\text { Wariancja luki pro- } \\
\text { dukcyjnej }\end{array}$ & $\begin{array}{c}\text { Wartość funkcji } \\
\text { straty }\end{array}$ \\
\hline Reguła adaptacyjna & 5,55 & 7,17 & 13,77 \\
\hline Reguła bieżąca & 4,33 & 8,39 & 11,55 \\
\hline $\begin{array}{l}\text { Reguła antycypa- } \\
\text { cyjna }\end{array}$ & 4,55 & 7,32 & 11,80 \\
\hline
\end{tabular}

W scenariuszu szoku oczekiwanego (na 4 kwartały wcześniej) największą wartość funkcji straty otrzymano dla modelu z regułą adaptacyjną, zaś najlepszą - z regułą bieżącą. Porównując wartości funkcji straty otrzymane dla odpowiednich modeli w scenariuszy szoku oczekiwanego i nieoczekiwanego, możemy zauważyć że wartości funkcji straty są lepsze lub porównywalne ${ }^{46}$. Do podobnych wniosków doprowadziła analiza współczynnika wyrzeczenia, z tym że wówczas

${ }^{46}$ Pewne wątpliwości budzi założenie odchylenia standardowego szoku oczekiwanego na takim samym poziomie jak dla szoku nieoczekiwanego. W Polsce szoki oczekiwane nie występowały lub występowały sporadycznie, stąd trudno jest przyjąć jakąkolwiek wartość odchylenia standardowego takich szoków. Jednak mając na uwadze porównywalność wyników przyjęto, że zmienność szoku oczekiwanego i nieoczekiwanego jest jednakowa. 
największa przewaga widoczna była dla modelu z regułą antycypacyjną, a obecnie - dla reguły adaptacyjnej.

Przedstawione w tabl. 4.3 i 4.4 wyniki dla scenariusza szoku nieoczekiwanego i nieoczekiwanego nie zmieniłyby się znacząco, gdyby przyjąć że jedynym szokiem jest szok polityki pieniężnej bądź też przyjąć inne wartości wagi inflacji w funkcji straty $\left(w_{\pi}\right.$, z przedziału $\left.(1 ;+\infty)\right)$.

\section{Symulacja w warunkach ,przełączania regul”}

Dotychczasowe symulacje przeprowadzono w trzech wariantach, w każdym z nich przyjmując inną postać reguły Taylora. Poszerzeniem tych analiz będą symulacje z wykorzystaniem modelu DSGE z ,przełączaniem reżimu”. Przyjmiemy, że równania hybrydowej krzywej Phillipsa, hybrydowej krzywej IS są niezmiennicze względem reżimu. Natomiast skokowym zmianom (przełączaniu) podlega reguła polityki pieniężnej (zmiany reżimu modelowane są za pomocą procesu Markowa).

Przypuszczamy, że wraz z rosnącą długością szeregów czasowych poprawiała się znajomość mechanizmów rządzących zachowaniem gospodarki Polski, a przez to zwiększała się jakość prognoz inflacji i luki ${ }^{47}$. To z kolei pozwalało przejść od reguły adaptacyjnej (sięgającej jedynie do danych historycznych) do reguły bieżącej (która korzystała z tzw. bieżącego monitoringu - nowcasting), a w końcu do reguły antycypacyjnej ${ }^{48}$.

Stąd też przyjęto, że z reżimu reguły adaptacyjnej możliwe jest przełączenie wyłącznie do reżimu reguły bieżącej, a z reżimu reguły bieżącej - wyłącznie do reżimu reguły antycypacyjnej. Prawdopodobieństwa tych przejść skalibrowano na poziomie 0,067 . Odpowiada to oczekiwanemu czasowi trwania reżimów: reguły adaptacyjnej i bieżącej na poziomie 15 kwartałów $^{49}$. Natomiast reżim reguły antycypacyjnej stanowi tzw. reżim pochłaniający (brak możliwości opuszczenia tego reżimu).

${ }^{47}$ Wcześniej na problem długości szeregów czasowych spoglądano z perspektywy możliwości wprowadzenia strategii bezpośredniego celu inflacyjnego w Polsce i innych krajach transformujących gospodarkę (por. np.: Baranowski, Krajewski, 2006, s. 30; Cendal, 2008b, s. 254, 281-282; Brzoza-Brzezina, 2011, s. 25).

${ }^{48}$ Możliwość taką zasugerował J.J. Sztaudynger w rozmowie (lipiec 2013).

${ }^{49}$ Wyznaczenie oczekiwanego czasu trwania reżimu dla przypadku analizowanego w tym rozdziale wymaga jedynie obliczenia wartości oczekiwanej rozkładu Poissona, gdyż zakładamy przejście wyłącznie do jednego reżimu oraz brak ,,powrotu” do poprzedniego reżimu. Metodę wyznaczania rozkładu czasu dojścia do reżimów pochłaniających w ogólnym przypadku opisuje Górajski (2009). 
Odpowiadało to następującej macierzy Markowa ${ }^{50}$ :

$$
Q=\left[\begin{array}{ccc}
0,933 & 0,067 & 0 \\
0 & 0,933 & 0,067 \\
0 & 0 & 1
\end{array}\right]
$$

Podobnie jak poprzednich częściach rozdziału, analizie poddamy reakcję na zacieśnienie polityki pieniężnej - nieoczekiwany szok polityki pieniężnej ustalony tak, aby uzyskać wzrost stopy procentowej o 0,5 p. proc. Zakładamy, że w horyzoncie symulacji nie nastąpi zmiana reżimu, jednak różnica tkwi w sposobie formułowania oczekiwań przez podmioty gospodarcze. Obecnie rozwiązanie racjonalnych oczekiwań uwzględnia możliwość przełączania reguł (szerzej opisane w: Farmer, Waggoner, Zha 2011).

Wyniki symulacji dla reżimu adaptacyjnego ${ }^{51}$.

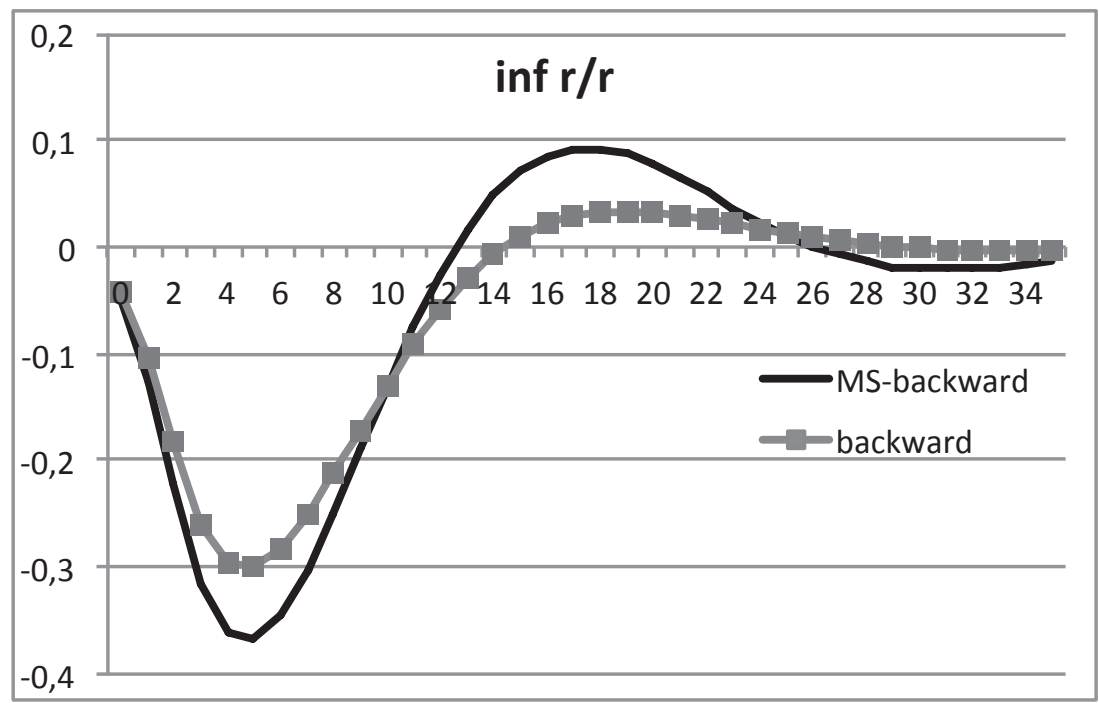

Wykres 29. Reakcja inflacji (r/r) na szok polityki pieniężnej dla reżimu reguły adaptacyjnej

${ }^{50}$ Poszczególne wiersze odpowiadają reżimowi wyjściowemu (odpowiednio: reguły adaptacyjnej, bieżące i antycypacyjnej), a kolumny - reżimowi docelowemu.

${ }^{51}$ Obliczenia wykonano za pomocą pakietu RISE (github.com/jmaih/RISE_toolbox). 


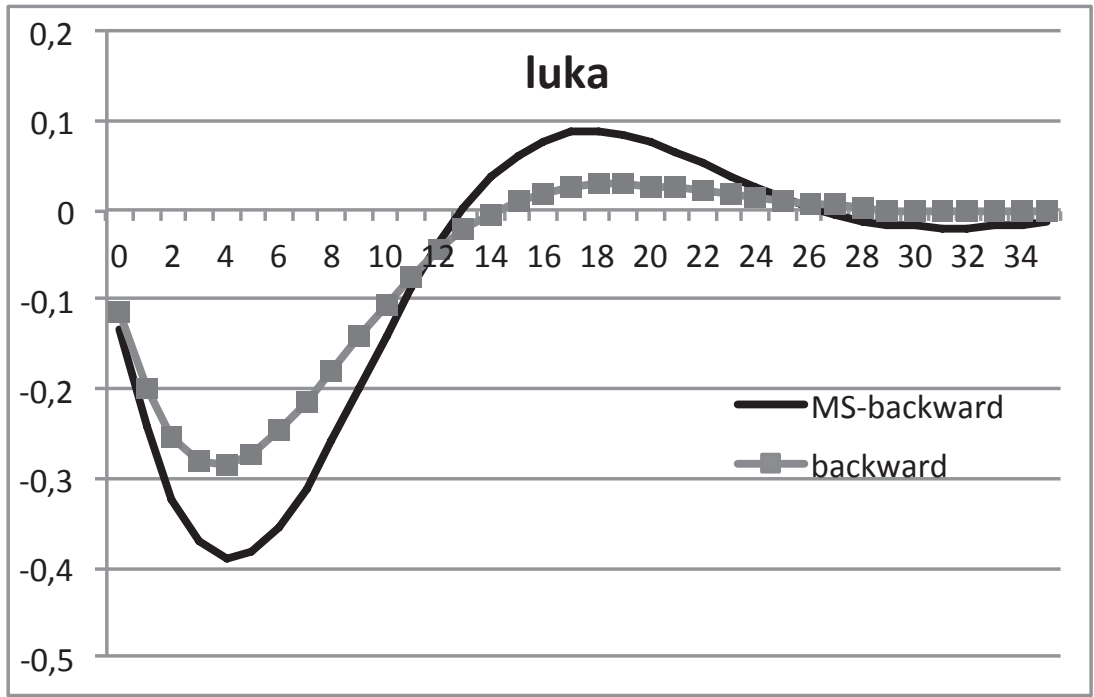

Wykres 30. Reakcja luki produkcyjnej na szok polityki pieniężnej dla reżimu reguły adaptacyjnej

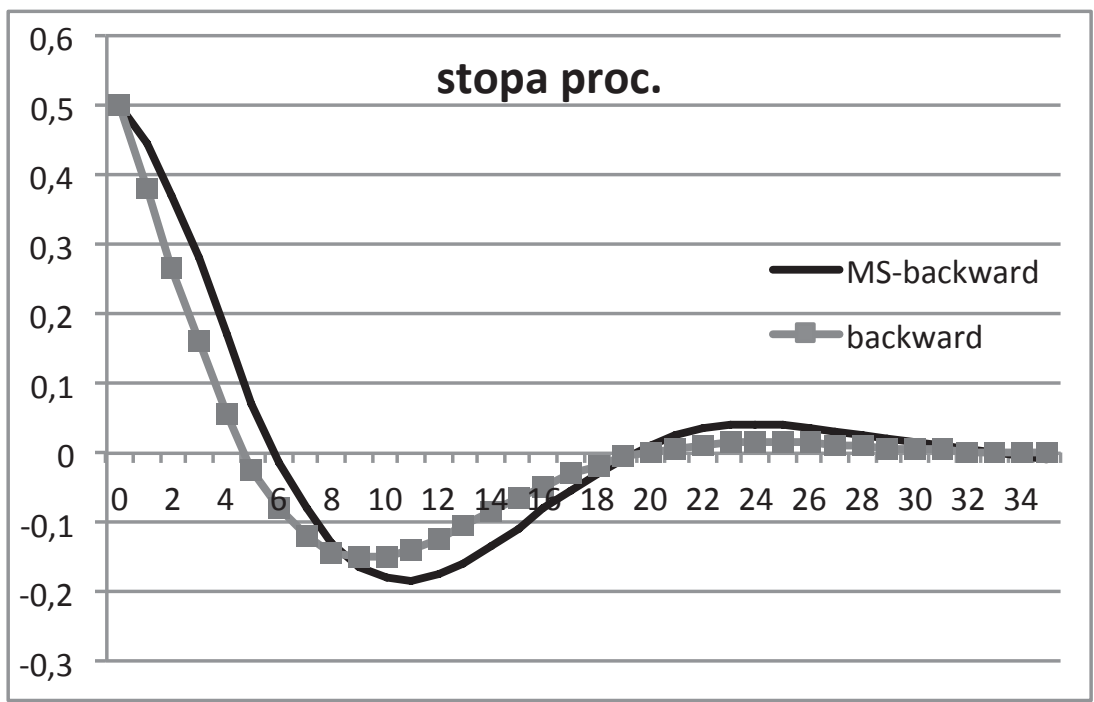

Wykres 31 Reakcja stopy procentowej na szok polityki pieniężnej dla reżimu reguły adaptacyjnej 
Analogiczne wyniki dla wyjściowego reżimu reguły bieżącej:

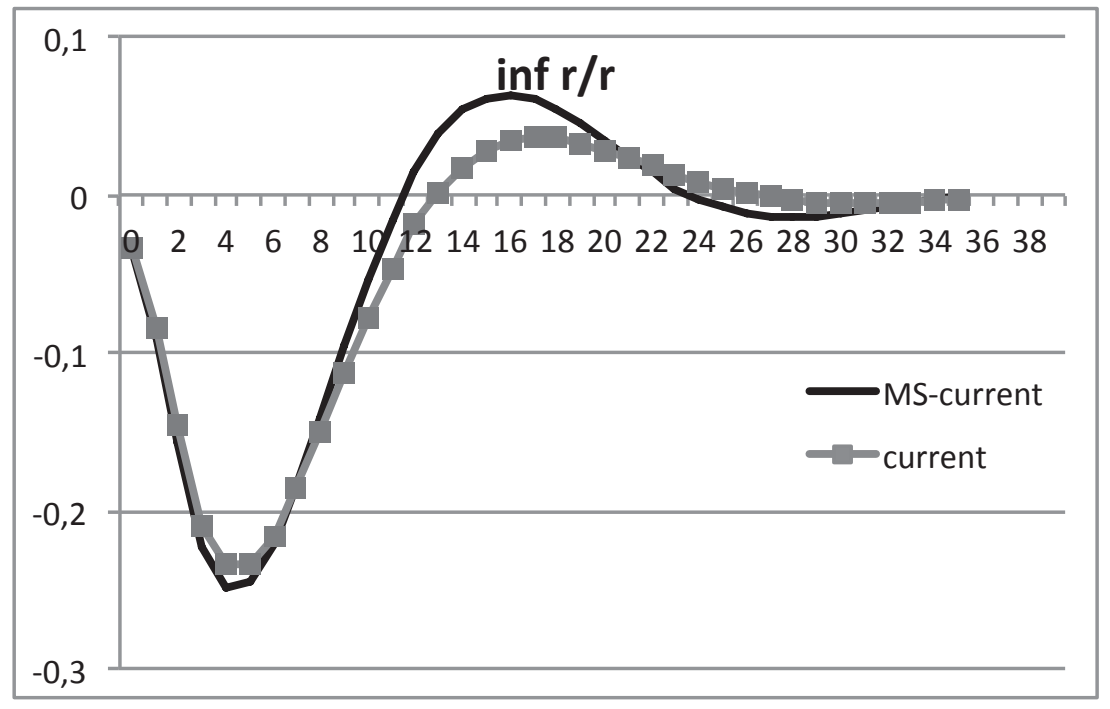

Wykres 32. Reakcja inflacji (r/r) na szok polityki pieniężnej dla reżimu reguły bieżącej

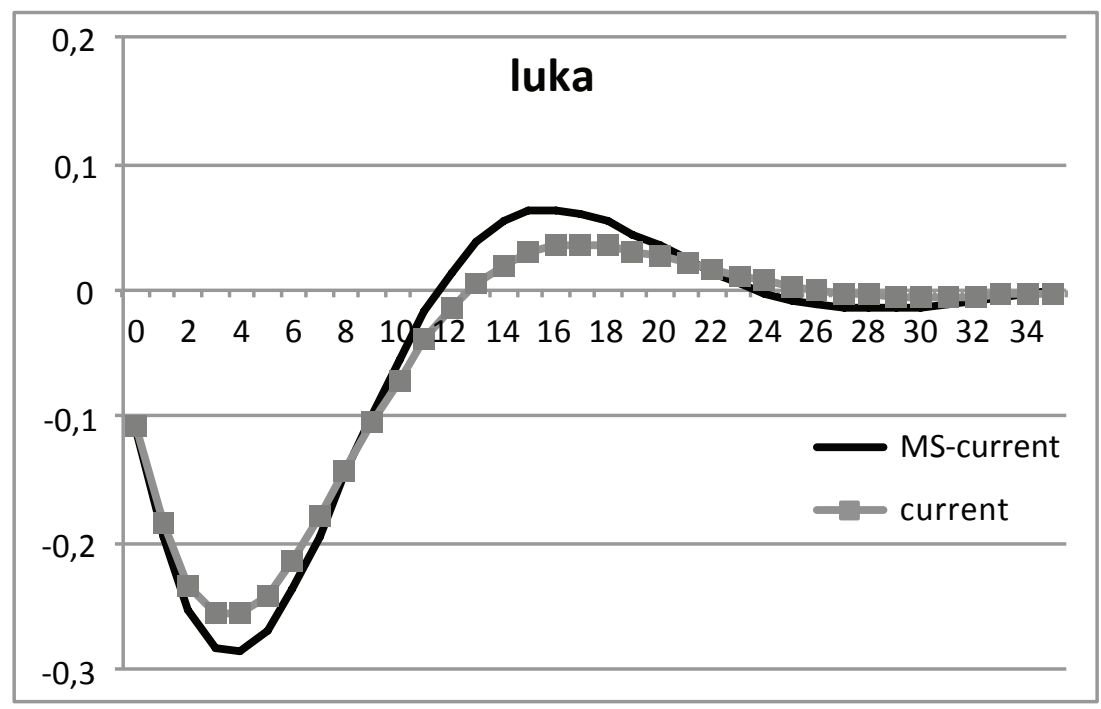

Wykres 33. Reakcja luki produkcyjnej na szok polityki pieniężnej dla reżimu reguły bieżącej 


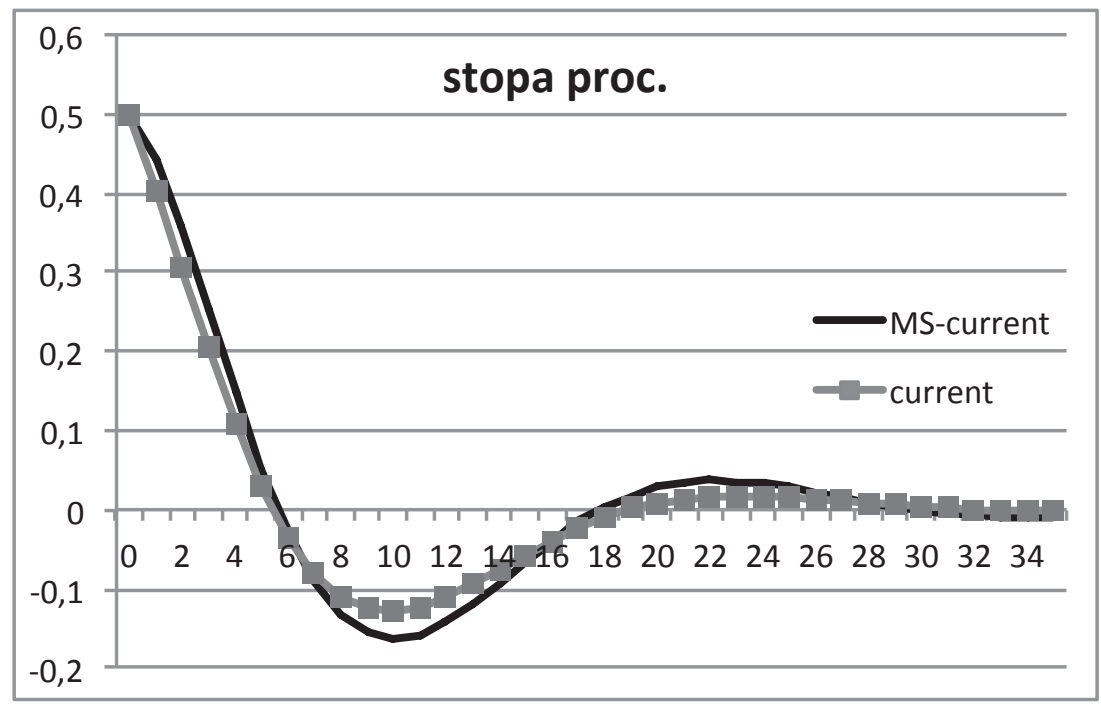

Wykres 34. Reakcja stopy procentowej na szok polityki pieniężnej dla reżimu reguły bieżącej

Porównując reakcję inflacji, luki i stopy procentowej dla reguły adaptacyjnej i bieżącej, możemy stwierdzić, że rozszerzenie założeń symulacji o zmiany reżimu nie zmieniło znacząco wyników. Przypomnijmy jednak że w dotychczasowych w symulacjach najsilniejsza reakcja inflacji i luki wystąpiła kolejno $\mathrm{w}$ modelu $\mathrm{z}$ regułą adaptacyjną, zaś najsłabsza $-\mathrm{z}$ regułą antycypacyjną (por. wykresy 27-28). W takim przypadku spodziewalibyśmy się, że w scenariuszu „przełączania reżimów” siła reakcji będzie większa niż w regule adaptacyjnej, a mniejsza niż w regule antycypacyjnej. Zaskakująco, otrzymana reakcja była silniejsza od wszystkich trzech modeli z poszczególnymi regułami analizowanymi „pojedynczo”. Różnica in plus jest szczególnie widoczna dla reguły adaptacyjnej - zob. wykresy 29-30). W przypadku modelu z racjonalnymi oczekiwaniami dopuszczających możliwość zmiany reżimu, reakcja taka jest teoretycznie możliwa (gdyż rozwiązanie zmienny reżim modelowany za pomocą procesu Markowa wprowadza dodatkową nieliniowość rozwiązania racjonalnych oczekiwań). Okazało się jednak, że wynika to z normalizacji wielkości szoku - tak aby początkowy wzrost stopy procentowej wyniósł $0,5 \mathrm{p}$. proc $^{52}$.

Należy dodać, że wykorzystano parametry reguł estymowanych na pełnej próbie (a przecież gdyby przełączanie miało miejsce, wówczas każda z reguł powinna „obowiązywać” w innym okresie). Ponadto arbitralnie założono prawdopodobieństwa zmiany stanu (elementy macierzy $Q$ ). Stąd przedstawione wyniki

${ }^{52}$ Normalizacja ta wpływała na różnice siły reakcji na szok oczekiwany i nieoczekiwany (efekt ten był szczególnie widoczny w modelu z regułą adaptacyjną). 
traktujemy z jednej strony jako uzupełnienie wyników otrzymanych dla trzech wariantów modeli (z różnymi regułami), a z drugiej jako punkt wyjścia do dalszych badań. Przypuszczamy, że metodyka „przełączanie reżimów” pozwoli rozpatrzyć także scenariusz zacieśnienia polityki pieniężnej, które może mieć charakter nieoczekiwany lub oczekiwany (z ustalonymi prawdopodobieństwami).

\section{Podsumowanie}

W rozdziale podjęto próbę analizy skutków polityki pieniężnej wykorzystując hybrydowy nowokeynesistowski model składający się z równań luki produkcyjnej i inflacji oraz zmodyfikowanej reguły Taylora (równania stopy procentowej). Parametry dwóch pierwszych równań modelu zostały oszacowane za pomocą uogólnionej metody momentów (GMM), na podstawie danych kwartalnych dla Polski. Analizowano trzy warianty, różniące się postacią reguły stopy procentowej - odpowiednio: adaptacyjna, bieżąca i antycypacyjna, na podstawie wyników z rozdziału 3.

W skonstruowanym modelu transmisja szoku polityki pieniężnej reprezentującego zacieśnienie polityki pieniężnej jest następująca. Na skutek wzrostu stopy procentowej gospodarstwa domowe zmniejszą bieżącą konsumpcję, na rzecz przyszłej, co generuje ujemną lukę produkcyjną. W warunkach niższego popytu, przedsiębiorstwa, które aktualizują cenę, ustalają ją na (ceteris paribus) niższym poziomie, co z kolei sprawia, że następuje spadek inflacji. Rezultaty symulacji obrazujących reakcję gospodarki na szok polityki pieniężnej można podsumować następująco.

Po pierwsze - w scenariuszu szoku nieoczekiwanego reakcja inflacji oraz luki produkcyjnej jest zgodna z przesłankami teoretycznymi. Najsilniejsza reakcja następuje 3-5 kwartałów po zacieśnieniu, po czym inflacja i luka stopniowo powracają do poziomu równowagi.

Po drugie - w scenariuszu szoku oczekiwanego, zapowiedzianego 4 kwartały wcześniej, reakcja inflacji oraz luki produkcyjnej jest również zgodna z przesłankami teoretycznymi. W przypadku luki produkcyjnej najsilniejszą reakcję obserwujemy 4-5 kwartałów po zapowiedzi szoku (tj. równocześnie z jego wystąpieniem lub 1 kwartał po jego wystąpieniu). Natomiast maksymalna reakcja inflacji występuje 5 kwartałów po zapowiedzi szoku (tj. 1 kwartał po jego wystąpieniu).

Po trzecie - w przypadku oczekiwanego zacieśnienia polityki pieniężnej efekty mogą być silniejsze niż w przypadku zacieśnienia nieoczekiwanego: dwukrotnie (dla reguły bieżącej i antycypacyjnej) lub niemal dziesięciokrotnie (dla reguły adaptacyjnej).

Po czwarte - oceniając skuteczność oddziaływania polityki pieniężnej przez pryzmat współczynnika wyrzeczenia możemy stwierdzić, że wcześniejsza (wiarygodna) zapowiedź zacieśnienia polityki pieniężnej sprawia, że dezinflacja 
nastąpi „kosztem” mniejszych spadków luki produkcyjnej. Do podobnych wniosków prowadzi porównanie wartości funkcji straty banku centralnego. Jednakże ze względu na fakt, iż w okresie pomiędzy zapowiedzią a realizacją oczekiwanego zacieśnienia monetarnego mogą nastąpić inne szoki (w szczególności wpływające na inflację), trudno jest na obecnym etapie badań rekomendować taki sposób prowadzenia polityki pieniężnej.

Po piąte - wyznaczone funkcje reakcji dla modeli DSGE z różnymi regułami są bardzo zbliżone. Podobne wnioski można wyciągnąć z porównania odpowiedzi na impuls w scenariuszu ,przełączania reguł". Na tej podstawie możemy odrzucić hipotezę H4 o istnieniu różnic w reakcji inflacji i luki produkcyjnej w modelach $\mathrm{z}$ różną regułą. 


\section{Załącznik 4.1. \\ Wyprowadzenie równania hybrydowej krzywej IS}

Warunek optymalnego międzyokresowego wyboru konsumpcji (tzn. wybór pomiędzy konsumpcją bieżącą $C_{t}^{I}$ a przyszłą $C_{t+1}^{I}$ ) określa się standardowo jako zrównanie ilorazu krańcowych użyteczności z relacją cen. Dla funkcji użyteczności (4.1) i wyboru w chwili $t$ przedstawia się on następująco:

$$
\begin{gathered}
\frac{\partial U(t)}{\partial C_{t}^{I}} / \boldsymbol{E}_{t} \frac{\partial U(t)}{\partial C_{t+1}^{I}}={ }^{P_{t}} / \frac{\boldsymbol{E}_{t} P_{t+1}}{1+i_{t}} \\
C_{t}^{I^{-\sigma}} /{ }_{\beta \boldsymbol{E}_{t} C_{t+1}^{I}-\sigma}=P_{t} / \frac{\boldsymbol{E}_{t} P_{t+1}}{1+i_{t}}
\end{gathered}
$$

Po obustronnym zlogarytmowaniu równania (Z1-2), możemy otrzymać następującą zależność, zwaną równaniem Eulera:

$$
\ln C_{t}^{I}=\ln \boldsymbol{E}_{t} C_{t+1}^{I}-1 / \sigma\left(i_{t}-\boldsymbol{E}_{t} \pi_{t+1}-\ln \beta\right)
$$

Podstawiając pod równanie agregacji (4.4), a także korzystając z tego, że łączna produkcja musi być równa konsumpcji, możemy zapisać następujące równania:

$$
\begin{aligned}
& \ln Y_{t}-\psi \ln Y_{t-1}=\left(\ln \boldsymbol{E}_{t} Y_{t+1}-\psi \ln Y_{t}\right)-\left(\frac{(1-\psi)}{\sigma}\left(i_{t}-\boldsymbol{E}_{t} \pi_{t+1}-\ln \beta\right)\right) \\
& \ln Y_{t}-\psi \ln Y_{t-1}=\left(\ln \boldsymbol{E}_{t} Y_{t+1}-\psi \ln Y_{t-1}\right)-\left(\frac{(1-\psi)}{\sigma}\left(i_{t}-\boldsymbol{E}_{t} \pi_{t+1}-\ln \beta\right)\right) \\
& \ln Y_{t}=\frac{1}{1+\psi} \ln \boldsymbol{E}_{t} Y_{t+1}+\frac{\psi}{1+\psi} \ln Y_{t-1}-\left(\frac{(1-\psi)}{\sigma(1+\psi)}\left(i_{t}-\boldsymbol{E}_{t} \pi_{t+1}-\ln \beta\right)\right)
\end{aligned}
$$

Zapisując równanie (Z1-6) dla wartości produkcji w długookresowej równowadze (tj. produkcji, jaka realizowałaby się przy doskonale elastycznych cenach, określanej także jako tzw. produkcja naturalna) otrzymamy:

$$
\ln Y_{t}^{*}=\frac{1}{1+\psi} \ln \boldsymbol{E}_{t} Y_{t+1}^{*}+\frac{\psi}{1+\psi} \ln Y_{t-1}^{*}-\left(\frac{(1-\psi)}{\sigma(1+\psi)}\left(i_{t}-\boldsymbol{E}_{t} \pi_{t+1}-\ln \beta\right)\right)
$$


Odejmując powyższe równania stronami, a następnie porządkując wyrazy otrzymamy:

$$
x_{t}=\gamma \boldsymbol{E}_{t} x_{t+1}+(1-\gamma) x_{t-1}+\sigma_{1}\left(i_{t}-\boldsymbol{E}_{t} \pi_{t+1}\right)
$$

gdzie:

$$
\begin{aligned}
& x_{t}=\ln Y_{t}-\ln Y_{t}^{*}-\text { luka produkcyjna, } \\
& \gamma=\frac{1}{1+\psi} \text { oraz } \sigma_{1}=-\frac{(1-\psi)}{\sigma(1+\psi)}
\end{aligned}
$$

\section{Załącznik 4.2.}

\section{Wyprowadzenie równania hybrydowej krzywej Phillipsa}

Formułę opisującą zysk (4.8) możemy przedstawić następująco:

$$
E_{t} \sum_{h=0}^{+\infty} S D F_{t, t+h} \theta^{h} P_{t}^{I} Y_{t+h}-E_{t} \sum_{h=0}^{+\infty} S D F_{t, t+h} \theta^{h} \frac{\tau}{\tau-1} T C\left(Y_{t+h}\right)
$$

gdzie:

$$
S D F_{t, t+h}=\beta^{h} \frac{\frac{\partial U(t)}{\partial C_{t+h}^{I}}}{\frac{\partial U(t)}{\partial C_{t}^{I}}} \frac{P_{t}}{P_{t+h}}-\text { stochastyczny czynnik dyskontujący strumie- }
$$

nie zmiennych nominalnych w okresie $t+h \mathrm{w}$ stosunku do okresu $t$.

W dalszej części skorzystamy z faktu, że w bliskim otoczeniu stanu równowagi długookresowej (steady-state) zachodzi $S D F_{t, t+h} \cong \beta^{h}$.

Dzieląc wyrażenie (Z2-1) przez cenę ustaloną przez przedsiębiorstwo optymalizujące w okresie poprzednim $\left(P_{t-1}^{I}\right)$, a następnie log-linearyzując wokół stanu równowagi otrzymujemy następujące wyrażenie (zob. np. Gali, 2008, s. 45):

$$
\sum_{h=0}^{+\infty} \beta^{h} \theta^{h}\left(\ln P_{t}^{I}-\ln P_{t-1}^{I}\right)-E_{t} \sum_{h=0}^{+\infty} \beta^{h} \theta^{h}\left(\widehat{R M C}_{t+h}+\ln P_{t+h}-\ln P_{t-1}\right)
$$

gdzie:

$$
R M C_{t+h}=\frac{\partial T C\left(Y_{t+h}\right)}{\partial Y_{t+h}} \frac{P_{t}}{P_{t+h}} \text { oznacza realne koszty krańcowe, }
$$

$\widehat{R M C}_{t+h}=\ln \left(R M C_{t+h}\right)-\ln \left(R M C_{t+h}^{*}\right)-$ procentowe odchylenie $R M C_{t}$ od wartości w stanie długookresowej równowagi.

Równanie (Z2-2) wygodnie jest zapisać z użyciem operatora opóźnieniaprzyspieszenia (tj. $\boldsymbol{L}^{-h} x_{t} \stackrel{\text { def }}{=} \boldsymbol{E}_{\boldsymbol{t}} x_{t+h}$ i dla $\boldsymbol{L}^{h} x_{t} \stackrel{\text { def }}{=} x_{t-h}$, zob. np. Romer 2011, 
s. 326-327). Korzystając z definicji inflacji, tj. $\pi_{t}^{I}=\ln P_{t}^{I}-\ln P_{t-1}^{I}$, można zapisać równość $\ln P_{t+h}-\ln P_{t-1}=\sum_{i=0}^{h} L^{-i} \pi_{t}$. Korzystając z tej konwencji otrzymujemy:

$$
\begin{gathered}
\sum_{h=0}^{+\infty} \beta^{h} \theta^{h}\left(\ln P_{t}^{I}-\ln P_{t-1}\right)=\sum_{h=0}^{+\infty} \beta^{h} \theta^{h} \widehat{R M C}+\sum_{h=0}^{+\infty} \beta^{h} \theta^{h}\left(\ln P_{t+h}-\ln P_{t-1}\right) \\
\sum^{+\infty} \beta^{h} \theta^{h}\left(\ln P_{t}^{I}-\ln P_{t-1}\right)=\sum^{+\infty} \beta^{h} \theta^{h} L^{-h} \widehat{R M C}+\sum^{+\infty} \beta^{h} \theta^{h} \sum^{h} L^{-i} \pi_{t}
\end{gathered}
$$

W celu lepszego zobrazowania podwójnej sumy w wyrażeniu (Z2-4) przedstawiamy w tab. Z-4.2 jej składniki dla kolejnych wartości indeksów $h$ oraz $i$.

\begin{tabular}{|c|c|c|c|c|c|}
\hline & $i=0$ & $i=1$ & $i=2$ & $i=3$ & $\ldots$ \\
\hline$h=0$ & $\pi_{t}$ & & & & \\
\hline$h=1$ & $\beta \theta \cdot \pi_{t}$ & $\beta \theta \cdot L^{-1} \pi_{t}$ & & & \\
\hline$h=2$ & $(\beta \theta)^{2} \cdot \pi_{t}$ & $(\beta \theta)^{2} \cdot L^{-1} \pi_{t}$ & $(\beta \theta)^{2} \cdot L^{-2} \pi_{t}$ & & \\
\hline$h=3$ & $(\beta \theta)^{3} \cdot \pi_{t}$ & $(\beta \theta)^{3} \cdot L^{-1} \pi_{t}$ & $(\beta \theta)^{3} \cdot L^{-2} \pi_{t}$ & $(\beta \theta)^{3} \cdot L^{-3} \pi_{t}$ & \\
\hline$\ldots$ & & & & & \\
\hline
\end{tabular}

Tabela Z-4.2. Składniki podwójnej sumy we wzorze (Z2-4)

Źródło: opracowanie własne.

Zmieniając kolejność sumowania możemy najpierw zapisać sumy dla wyrazów leżących po przekątnej tab. Z-4.2. Wynoszą one odpowiednio (dla: $i=h, i=h+1, i=h+2$, itd. $): \sum_{i=0}^{+\infty}(\beta \theta)^{i} L^{-i} \pi_{t}, \beta \theta \sum_{i=0}^{+\infty}(\beta \theta)^{i} L^{-i} \pi_{t},(\beta \theta)^{2} \sum_{i=0}^{+\infty}(\beta \theta)^{i} L^{-i} \pi_{t}$
itd.

Korzystając z własności sumy ciągu geometrycznego możemy uprościć nieskończone sumy, co pozwoli zapisać:

$$
\frac{1}{1-\beta \theta}\left(\ln P_{t}^{I}-\ln P_{t-1}\right)=\frac{1}{1-\beta \theta L^{-1}} \widehat{R M C}_{t}+\frac{1}{1-\beta \theta L^{-1}} \sum_{j=0}^{+\infty}(\beta \theta)^{j} \pi_{t}
$$

A następnie stosując ten zabieg ponownie do ostatniej sumy wyrażenia (Z2-5) otrzymamy: 


$$
\frac{1}{1-\beta \theta}\left(\ln P_{t}^{I}-\ln P_{t-1}\right)=\frac{1}{1-\beta \theta L^{-1}} \widehat{R M C}_{t}+\frac{1}{1-\beta \theta L^{-1}} \frac{1}{1-\beta \theta} \pi_{t}
$$

Zestawiając równanie (Z2-6) z równaniem agregacji (4.11), otrzymujemy:

$$
\begin{gathered}
\frac{1}{1-\beta \theta} \frac{1}{(1-\omega)(1-\theta)}\left(\pi_{t}-\omega \pi_{t-1}\right)=\frac{1}{1-\beta \theta L^{-1}} \widehat{R M C}_{t} \\
+\frac{1}{1-\beta \theta L^{-1}} \frac{1}{1-\beta \theta} \pi_{t}
\end{gathered}
$$

Porządkując wyrazy otrzymamy kolejno:

$$
\begin{gathered}
\left(\frac{1}{(1-\omega)(1-\theta)}-\frac{1}{1-\beta \theta L^{-1}}\right) \pi_{t}=\frac{1-\beta \theta}{1-\beta \theta L^{-1}} \widehat{R M C}_{t} \\
+\frac{\omega}{(1-\omega)(1-\theta)} \pi_{t-1} \\
\left(\frac{1-\beta \theta L^{-1}-(1-\omega)(1-\theta)}{(1-\omega)(1-\theta)}\right) \pi_{t}=\frac{1-\beta \theta}{1-\beta \theta L^{-1}}(1-\beta \theta) \widehat{R M C}_{t} \\
+\frac{\omega\left(1-\beta \theta L^{-1}\right)}{(1-\omega)(1-\theta)} \pi_{t-1}
\end{gathered}
$$

Otrzymane równanie możemy zapisać w postaci:

$$
\begin{gathered}
\pi_{t}=\frac{\omega}{(\theta+\omega-\theta \omega+\omega \beta \theta)} \pi_{t-1}+\frac{\beta \theta}{(\theta+\omega-\theta \omega+\omega \beta \theta)} E_{t} \pi_{t+1} \\
+\frac{(1-\omega)(1-\theta)(1-\beta \theta)}{(\theta+\omega-\theta \omega+\omega \beta \theta)} \widehat{R M C}_{t}
\end{gathered}
$$

Następnie skorzystamy z warunku optymalnego wyboru wewnątrzokresowego gospodarstw domowych (tzn. pomiędzy konsumpcją bieżącą $C_{t}^{I}$ a ilością świadczonej pracy $L_{t}^{I}$ ).

$$
\frac{\partial U(t)}{\partial C_{t}^{I}} / \frac{\partial U(t)}{\partial L_{t}^{I}}=P_{t} /-W_{t}
$$

Dla funkcji użyteczności (4.1) i wyboru w chwili $t$ warunek (Z2-11) przedstawia się następująco:

$$
C_{t}^{I^{-\sigma}} /-L_{t}^{I \eta}=P_{t} /-W_{t}
$$

Ze względu na fakt, że rynek pracy ma strukturę konkurencji doskonałej, wszystkie gospodarstwa domowe świadczą tę samą ilość pracy $\left(L_{t}^{I}=L_{t}^{I I}=L_{t}\right)$, co za tym idzie analogiczny warunek możemy zapisać 
dla adaptacyjnych gospodarstwach domowych. Po ich agregacji a następnie zlogarytmowaniu stronami otrzymujemy:

$$
-\sigma \ln \left(C_{t}\right)-n \ln \left(L_{t}\right)=-\ln \left(W_{t} / P_{t}\right)
$$

Wstawiając tożsamość $Y_{t}=C_{t}$ oraz równanie popytu na pracę wyznaczone z funkcji produkcji, w postaci: $\ln \left(L_{t}\right)=(1 / 1-\alpha) \ln \left(Y_{t}\right)-\ln (\alpha / 1-\alpha) \ln (K)$ $-(1 / 1-\alpha) \ln (A)$ otrzymamy z dokładnością co do stałej:

$$
-\sigma \ln \left(Y_{t}\right)-(\eta / 1-\alpha) \ln \left(Y_{t}\right)=\ln \left(W_{t} / P_{t}\right)
$$

Następnie możemy realne koszty krańcowe można wyrazić jako iloraz płacy realnej i wydajności pracy, co implikuje w naszym przypadku:

$$
\begin{aligned}
\ln \left(R M C_{t}\right)= & \left(W_{t} / P_{t}\right)-\left(\ln Y_{t}-\ln L_{t}\right)=\ln \left(W_{t} / P_{t}\right)+\alpha \ln L_{t} \\
& =\ln \left(W_{t} / P_{t}\right)+(\alpha / 1-\alpha) \ln \left(Y_{t}\right)
\end{aligned}
$$

Wstawiając równanie (Z2-15) otrzymujemy:

$$
\ln \left(R M C_{t}\right)=\frac{\sigma(1-\alpha)+\eta+\alpha}{1-\alpha} \ln \left(Y_{t}\right)
$$

Równanie to może być wyrażone w kategoriach procentowych odchyleń od równowagi i określa $\mathrm{w}$ takim wypadku zależność pomiędzy procentowych odchyleniem realnych kosztów krańcowych a luką produkcyjną:

$$
\widehat{R M C}_{t}=\frac{\sigma(1-\alpha)+\eta+\alpha}{1-\alpha} x_{t}
$$

Wstawiając wyrażenie (Z2-17) do równania (Z2-12) otrzymujemy nowokeynesistowską hybrydową krzywą Phillipsa:

$$
\pi_{t}=\beta_{B} \pi_{t-1}+\beta_{F} E_{t} \pi_{t-1}+\kappa x_{t}
$$

gdzie:

$$
\begin{aligned}
& \beta_{F}=\frac{\beta \theta}{(\theta+\omega-\theta \omega+\omega \beta \theta)} \\
& \beta_{B}=\frac{\omega}{(\theta+\omega-\theta \omega+\omega \beta \theta)} \\
& \kappa=\frac{(1-\omega)(1-\theta)(1-\beta \theta)}{(\theta+\omega-\theta \omega+\omega \beta \theta)} \frac{\sigma(1-\alpha)+\eta+\alpha}{1-\alpha}
\end{aligned}
$$




\section{Załącznik 4.3. \\ Analiza wrażliwości funkcji reakcji na szok polityki pieniężnej}

W celu analizy wrażliwości przeprowadzono 50000 symulacji, w każdej losując parametry z rozkładu normalnego o parametrach przedstawionych poniżej. Wartości oczekiwane rozkładów zostały przyjęte zgodnie z punktowymi oszacowaniami parametrów (z rozdz. 3 - w przypadku reguł oraz z rozdz. 4 - w przypadku równania dynamicznej IS i hybrydowej krzywej Phillipsa). Z kolei wariancje rozkładów odzwierciedlały błędy szacunku poszczególnych parametrów otrzymane w estymacji na podstawie pełnej próby. W ten sposób przyjęto następujące rozkłady ${ }^{53}$ :

$$
\begin{aligned}
& \beta_{F}^{(i)} \sim N\left(0,610 ; 0,068^{2}\right) \quad \kappa^{(i)} \sim N\left(0,0112 ; 0,0059^{2}\right) \\
& \gamma^{(i)} \sim N\left(0,483 ; 0,039^{2}\right) \quad \sigma_{1}^{(i)} \sim N\left(-0,102 ; 0,032^{2}\right)
\end{aligned}
$$

A dla reguł polityki pieniężnej odpowiednio:

a) reguła adaptacyjna:

$$
\begin{array}{ll}
\rho^{(i)} \sim N\left(0,988 ; 0,019^{2}\right) & \phi_{\pi}^{(i)} \sim N\left(0,230 ; 0,053^{2}\right) \\
\phi_{\Delta \pi}^{(i)} \sim N\left(0,214 ; 0,099^{2}\right) & \phi_{\Delta x}^{(i)} \sim N\left(0,209 ; 0,043^{2}\right)
\end{array}
$$

b) reguła bieżąca:

$\rho^{(i)} \sim N\left(0,965 ; 0,02^{2}\right) \quad \phi_{\pi}^{(i)} \sim N\left(0,370 ; 0,055^{2}\right) \phi_{\Delta x}^{(i)} \sim N\left(0,152 ; 0,046^{2}\right)$

c) reguła antycypacyjna:

$$
\rho^{(i)} \sim N\left(0,961 ; 0,016^{2}\right) \quad \phi_{\pi}^{(i)} \sim N\left(0,424 ; 0,051^{2}\right)
$$

Z tak wyznaczonych parametrów (założono niezależność rozkładów) każdorazowo wyznaczano funkcje odpowiedzi na impuls ${ }^{54}$. Na wykresach prezentujemy medianę (najgrubsza, środkowa linia) wraz z $90 \%$ przedziałem ufności (tj. 5 i 95 percentyl rozkładu - linie przerywane), reprezentującym niepewność co do przyjętych parametrów.

${ }^{53}$ Superskrypt (i) oznaczaj numer symulacji $(i=1, \ldots, 50000)$. N $(a, b)$ oznacza rozkład normalny o wartości oczekiwanej $a$ oraz wariancji $b$.

${ }^{54}$ Dla około 2000 wylosowanych parametryzacji (tj. w 4\% przypadków) nie był spełniony warunek istnienia jednoznacznego rozwiązania racjonalnych oczekiwań. 
a) reguła adaptacyjna, szok nieoczekiwany

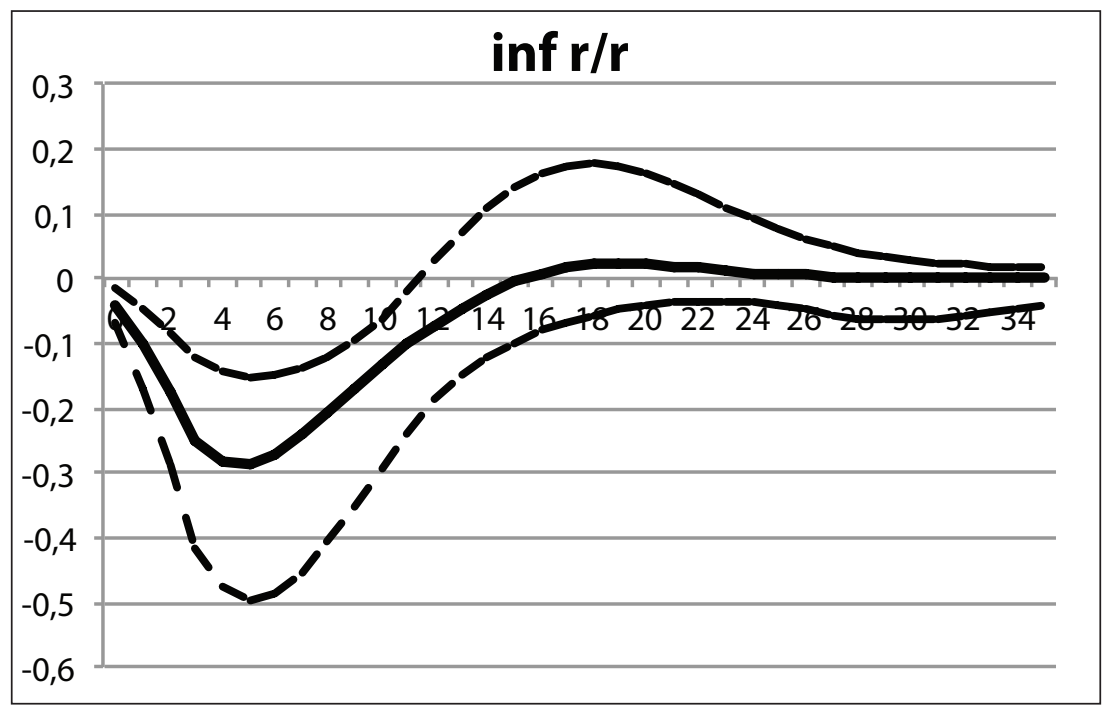

Wykres Z3-1. Reakcja inflacji (r/r) na szok polityki pieniężnej

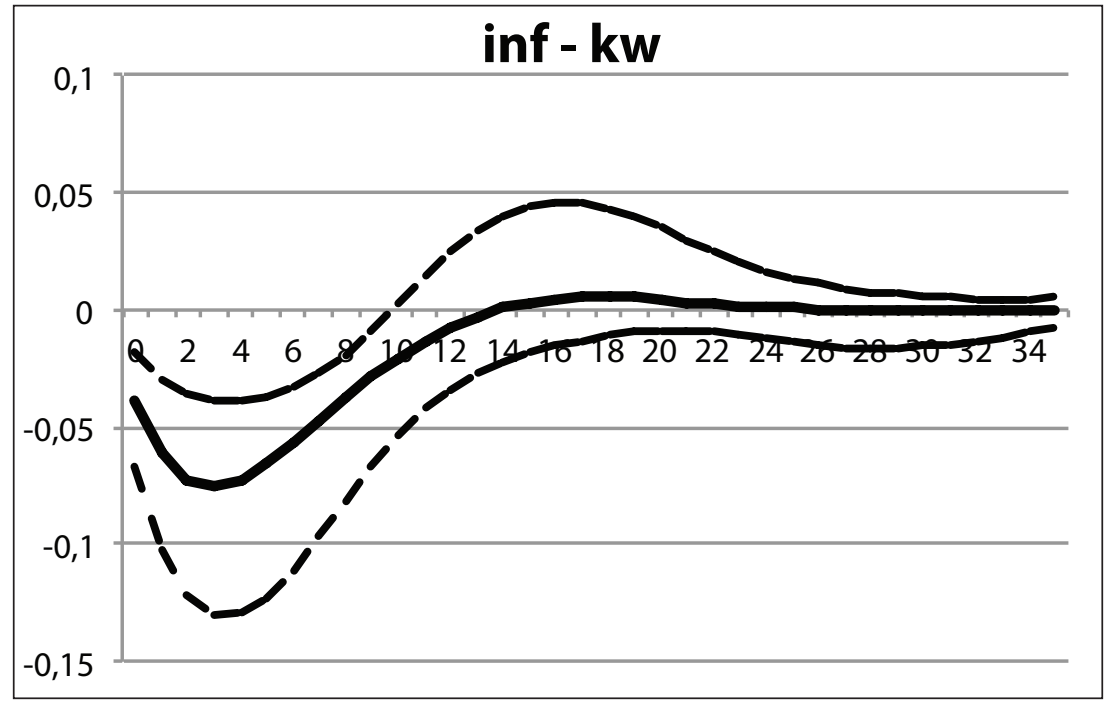

Wykres Z3-2. Reakcja inflacji (kw./kw.) na szok polityki pieniężnej 


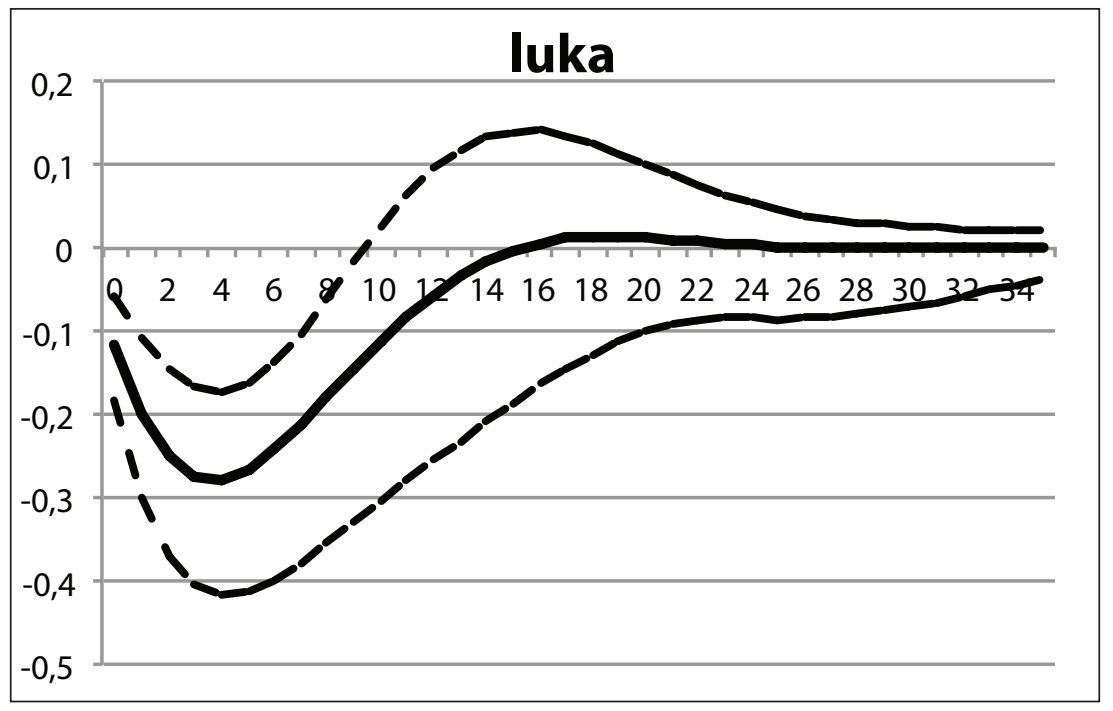

Wykres Z3-3. Reakcja luki produkcyjnej na szok polityki pieniężnej

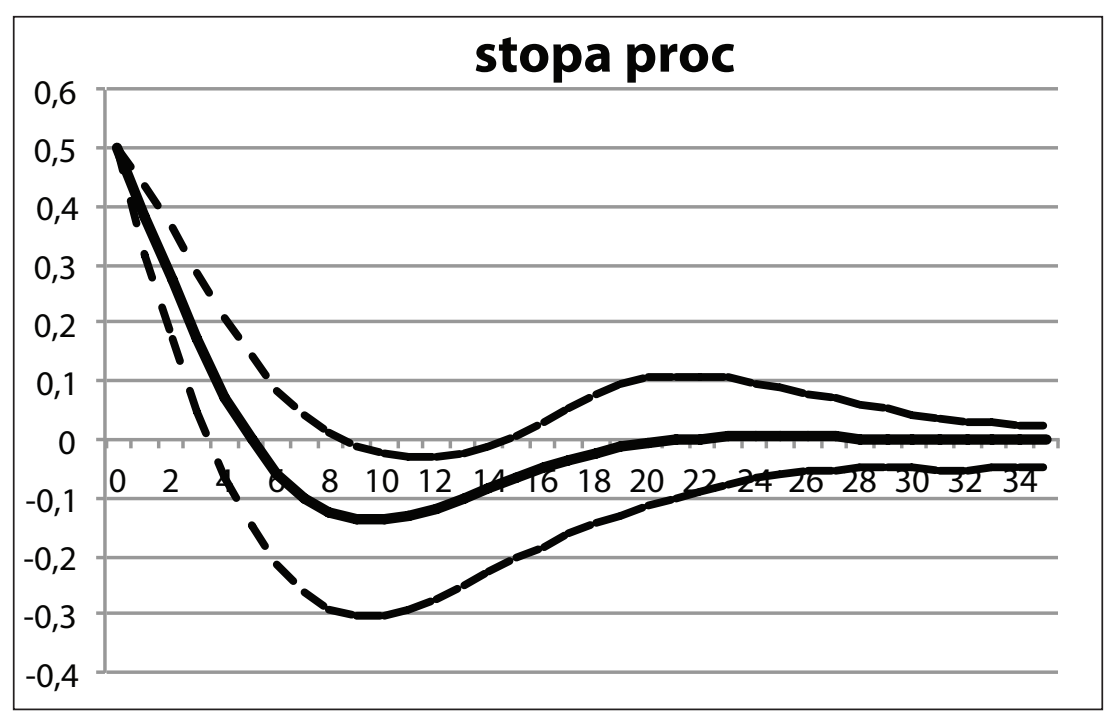

Wykres Z3-4. Reakcja stopy procentowej na szok polityki pieniężnej 
b) reguła bieżąca, szok nieoczekiwany

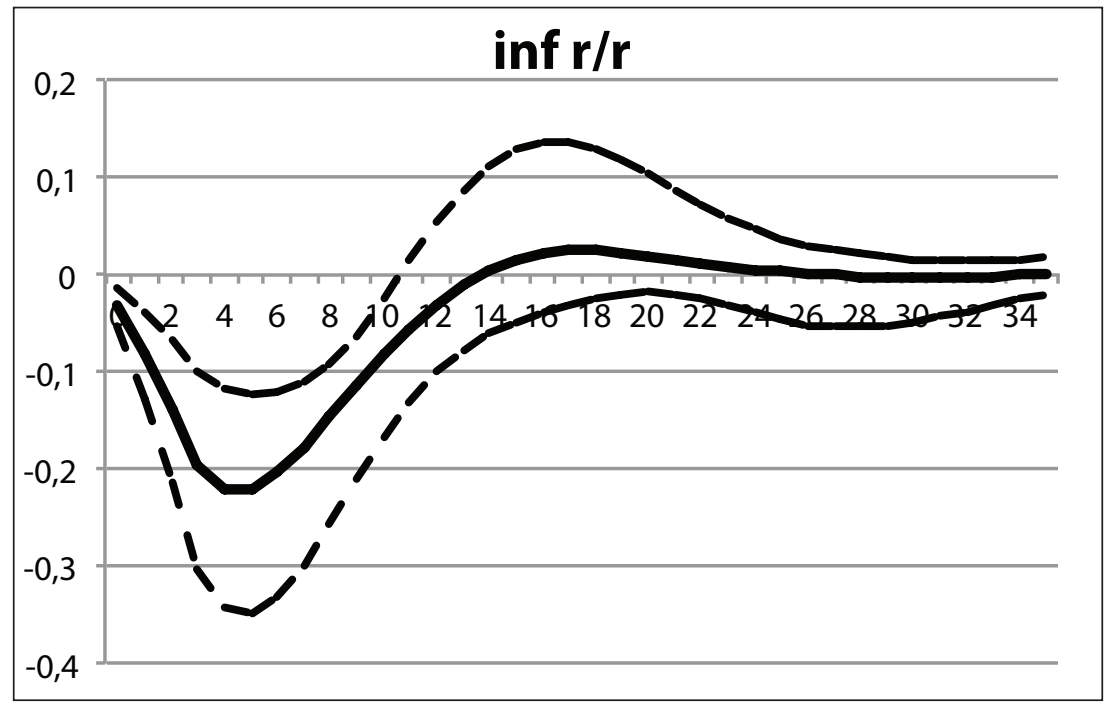

Wykres Z3-5: Reakcja inflacji (r/r) na szok polityki pieniężnej

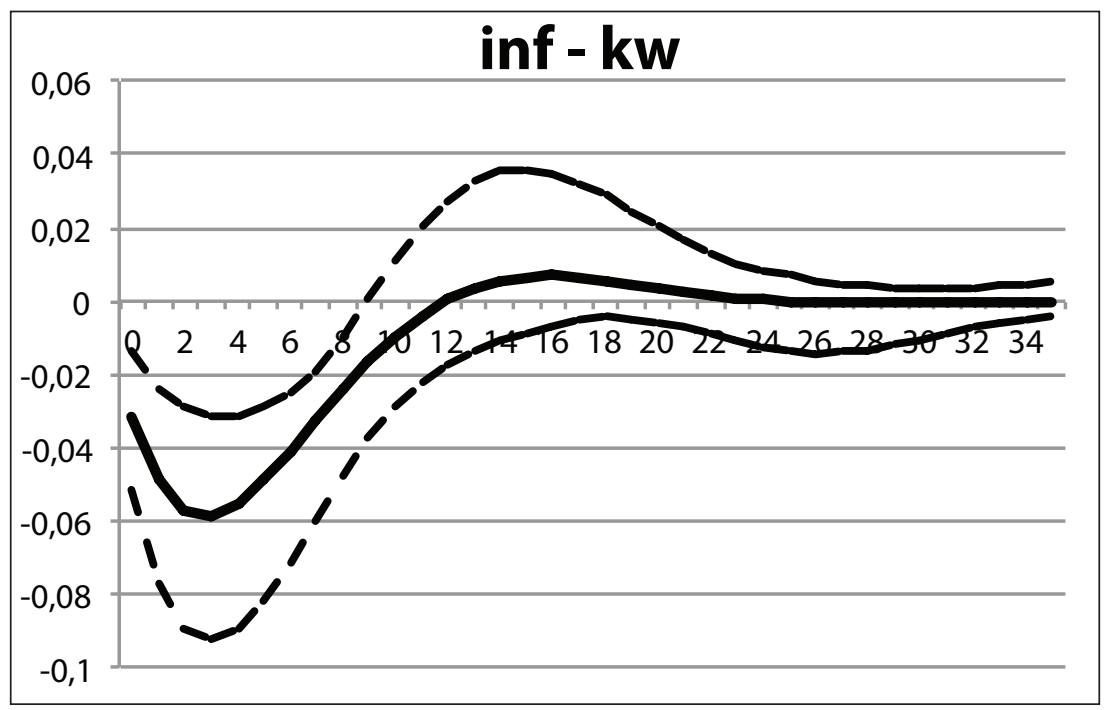

Wykres Z3-6: Reakcja inflacji (kw./kw.) na szok polityki pieniężnej 


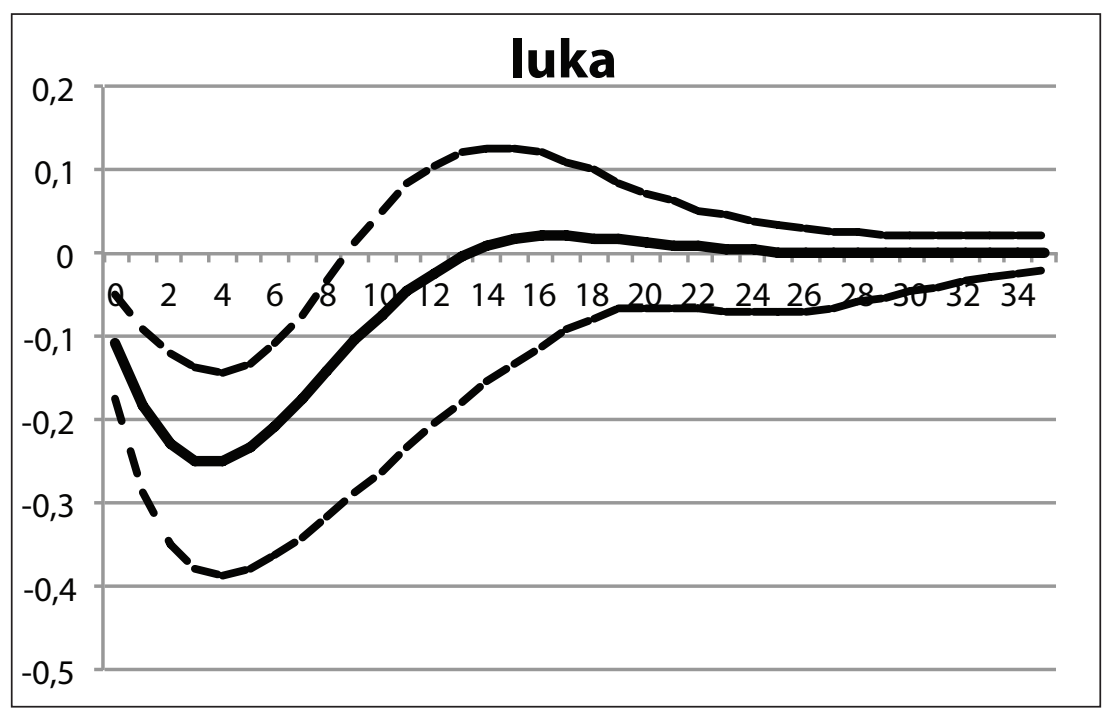

Wykres Z3-7: Reakcja luki produkcyjnej na szok polityki pieniężnej

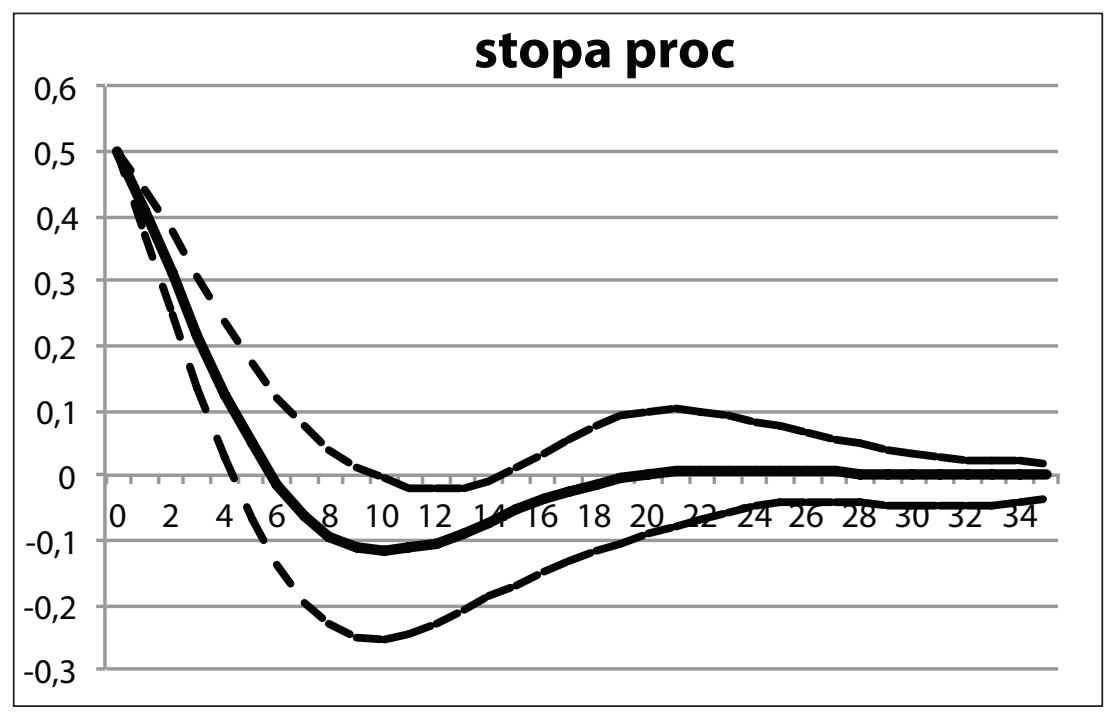

Wykres Z3-8: Reakcja stopy procentowej na szok polityki pieniężnej 
c) reguła antycypacyjna, szok nieoczekiwany

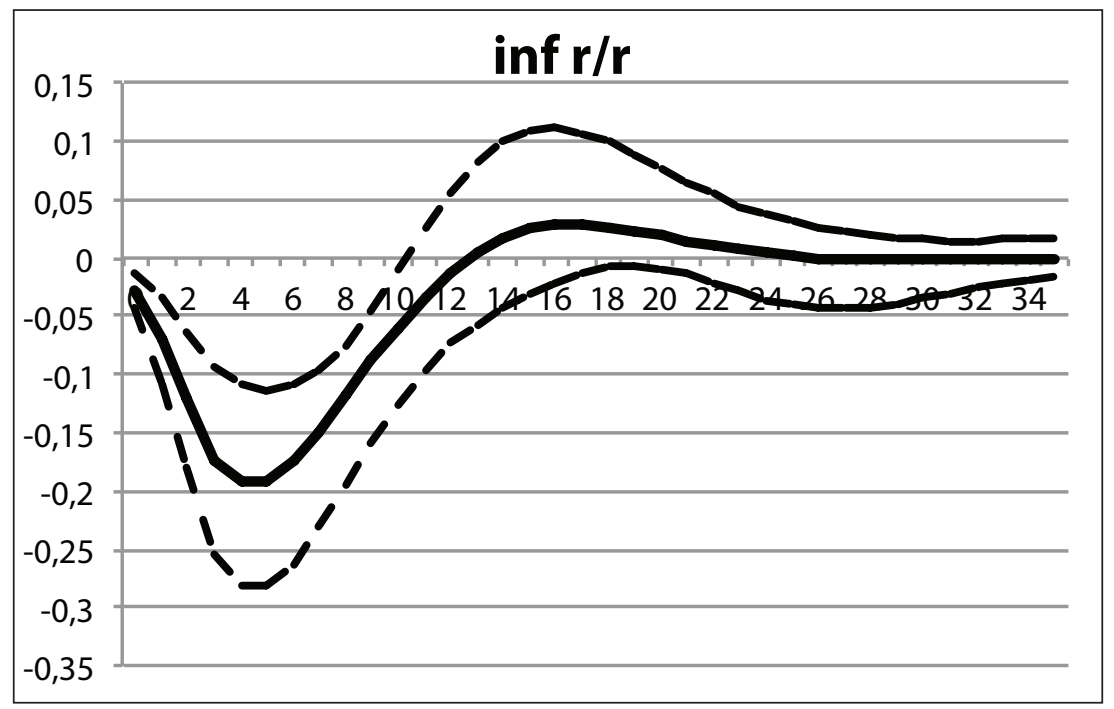

Wykres Z3-9. Reakcja inflacji (r/r) na szok polityki pieniężnej

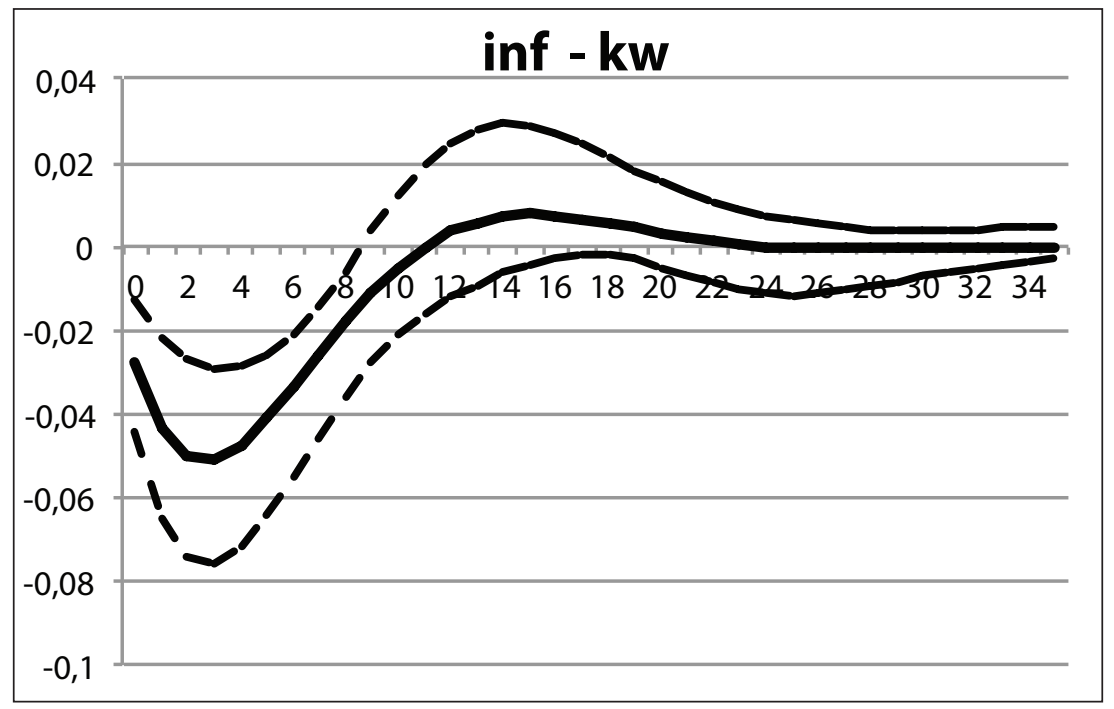

Wykres Z3-10. Reakcja inflacji (kw./kw.) na szok polityki pieniężnej 


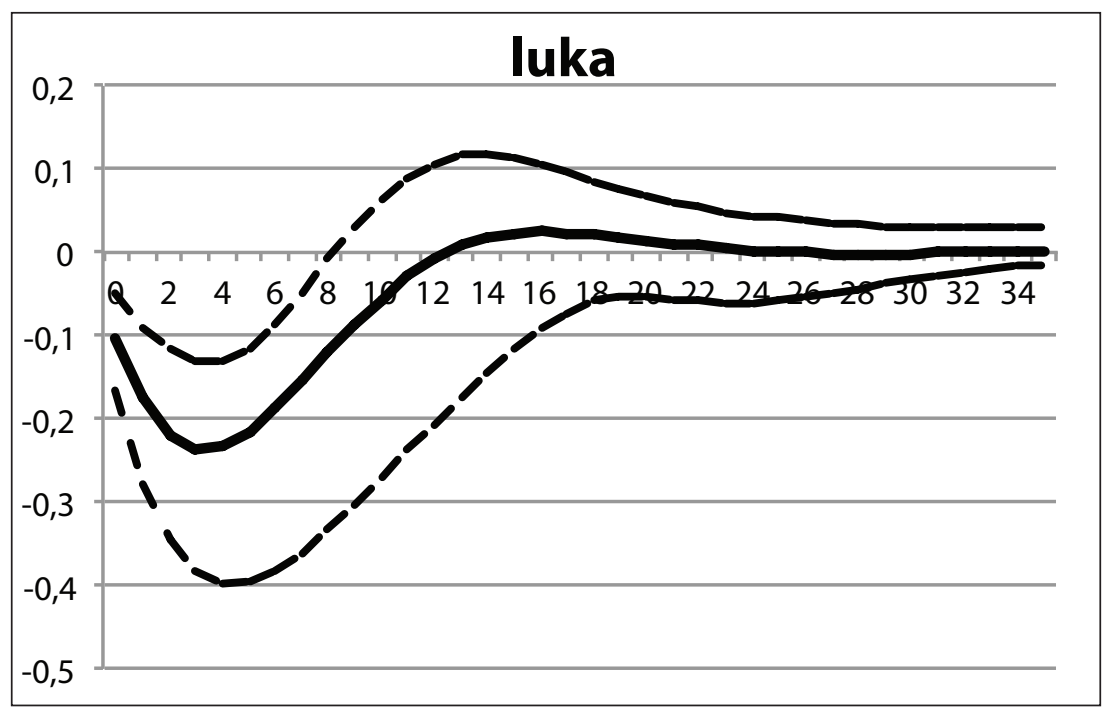

Wykres Z3-11. Reakcja luki produkcyjnej na szok polityki pieniężnej

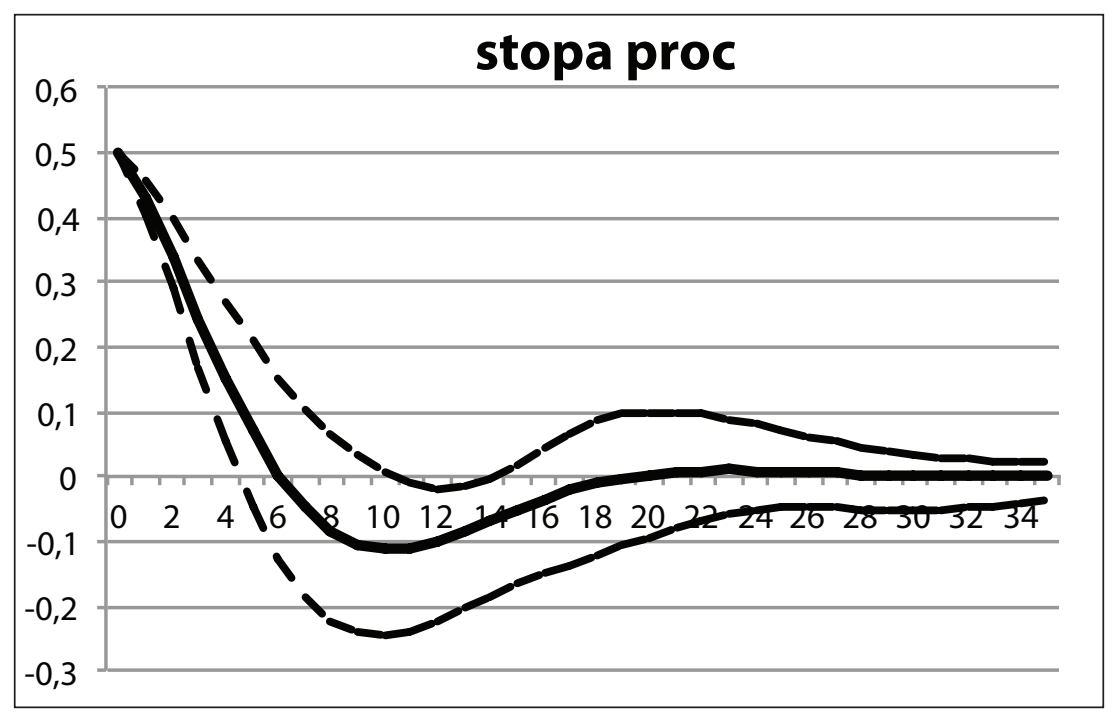

Wykres Z3-12. Reakcja stopy procentowej na szok polityki pieniężnej 


\section{ZAKOŃCZENIE}

Przytoczone w pracy modele niespójności polityki pieniężnej w czasie (Kydland, Prescott, 1977; Barro, Gordon 1983) wskazują, że polityka pieniężna powinna być prowadzona z zastosowaniem reguł. Stosowanie reguły celów, szczególnie w formie bezpośredniego celu inflacyjnego (w Polsce od początku 1999 roku), stabilizuje na niskim poziomie oczekiwania inflacyjne, a co za tym idzie pozwala na utrzymanie w długim okresie niższej inflacji.

Skuteczna realizacja reguły celów (strategii polityki pieniężnej) wymaga, aby bank centralny odpowiednio dostosowywał wartości instrumentów polityki pieniężnej do zmieniających się uwarunkowań makroekonomicznych. Modelowy opis tego typu „reakcji” banku centralnego nazywany jest w literaturze regułą instrumentów. Punktem wyjścia zdecydowanej większości badań poświęconych regułom instrumentów jest propozycja Taylora (1993), zgodnie z którą inflacja i luka produkcyjna wywierają dodatni wpływ na nominalną stopę procentową.

Nominalna stopa procentowa stanowi główny instrument polityki pieniężnej m.in. Narodowego Banku Polskiego. Dlatego też w książce przyjęto regułę Taylora jako podstawę ilościowej analizy polityki pieniężnej w Polsce w okresie obowiązywania strategii bezpośredniego celu inflacyjnego.

$\mathrm{Z}$ punktu widzenia postawionego celu pracy poszukiwano odpowiedzi na następujące pytania badawcze.

1) W jaki sposób nominalna stopa procentowa - główna miara stopnia restrykcyjności polskiej polityki pieniężnej, reaguje na zmiany inflacji i luki produkcyjnej?

2) Jak zmienia się inflacja i luka produkcyjna w Polsce pod wpływem szoku polityki pieniężnej - rozumianego jako krótkookresowe podwyższenie stopy procentowej ponad wartość wynikającą z reguły?

Realizacji celu pracy oraz pytaniom badawczym podporządkowano układ książki.

Początkowo dokonano krytycznego przeglądu literatury poświęconej roli reguł $\mathrm{w}$ teorii ekonomii, a także zagadnieniom metodologicznym istotnym dla dalszych badań empirycznych: pomiarowi inflacji i luki produkcyjnej oraz estymacji za pomocą uogólnionej metody momentów. Rozdział drugi poświęcono regule Taylora oraz jej najważniejszym rozszerzeniom. Z przytoczonej literatury wynika w szczególności, że podstawą dotychczasowych badań 
były modele stopy procentowej różniące się specyfikacją dynamiczną. Zagadnienie to wydaje się być szczególnie ważne, gdyż na gruncie teoretycznym trudno przesądzić czy stopień restrykcyjności polityki pieniężnej kształtują informacje dotyczące: przeszłych, bieżących bądź przyszłych-oczekiwanych wartości inflacji i luki produkcyjnej.

Brak takiego rozstrzygnięcia co do specyfikacji dynamicznej reguły Taylora sprawił, że próba odpowiedzi na pierwsze pytanie badawcze wymagała równoległego oszacowania trzech wariantów reguł. Zakładały one, że bank centralny korzysta z: przeszłej inflacji i luki produkcyjnej (reguła adaptacyjna), bieżącej inflacji i luki (reguła bieżąca) bądź przyszłej-oczekiwanej inflacji i luki (reguła antycypacyjna). Jednocześnie wydaje się, że standardowo stosowanym podejściem jest uwzględnienie wygładzania stóp procentowych. Taka konstrukcja modelu odzwierciedla tendencję do serii stopniowych zmian stóp procentowych, zamiast jednej dużej zmiany. Mechanizm wygładzania stóp procentowy będziemy zatem weryfikować we wszystkich trzech analizowanych wariantach reguły Taylora.

W rozdziale 3 przedstawiono wyniki badania empirycznego, w którym wykorzystano dane kwartalne dla gospodarki Polski w okresie realizacji strategii bezpośredniego celu inflacyjnego (za lata 1999-2012). W tej części pracy weryfikowaliśmy następujące hipotezy badawcze:

H1) wzrost inflacji i luki produkcyjnej powoduje wzrost stopy procentowej,

H2) występuje mechanizm wygładzania stóp procentowych,

H3) parametry reguły stopy procentowej są stabilne w czasie,

H4) reakcja inflacji i luki produkcyjnej różni się znacząco w zależności od przyjętej specyfikacji dynamicznej równania reguły.

Otrzymane wyniki dla wszystkich trzech analizowanych wariantów reguły wskazywały na silną dodatnią reakcję stopy procentowej na zmiany inflacji. Nie potwierdzono natomiast wpływu luki produkcyjnej (w regule adaptacyjnej i bieżącej potwierdzono jedynie wpływ krótkookresowy). Uznajemy na tej podstawie, że hipotezę $\mathrm{H} 1$ potwierdzono częściowo - w zakresie wpływu inflacji na stopę procentową.

We wszystkich analizowanych wariantach otrzymano silne wygładzanie stóp procentowych, co oznacza, że reakcja stóp procentowych na zmiany inflacji jest bardzo rozłożona w czasie. Tym samym potwierdzono hipotezę $\mathrm{H} 2$.

W celu weryfikacji hipotezy $\mathrm{H} 3$ początkowo dokonano estymacji na rozszerzających się podpróbach. Na tej podstawie stwierdziliśmy, że oceny parametrów reguły Taylora są stosunkowo stabilne. Ponadto nie potwierdziliśmy zmian parametrów pomiędzy podpróbami odpowiadającymi kadencjom Rady Polityki Pieniężnej (z wyjątkiem parametru związanego z przyrostem luki produkcyjnej w regule adaptacyjnej). Uzyskane wyniki pozwalają potwierdzić hipotezę o stabilności parametrów reguły Taylora. 
Ekonomiczna i statystyczna ocena wyników każdej z trzech specyfikacji reguły Taylora nie pozwoliła na wykluczenie któregokolwiek z nich. Jednocześnie otrzymane oceny parametrów, różniły się w zależności od przyjętej specyfikacji reguły. Dlatego w dalszych obliczeniach analizowano równolegle wszystkie trzy warianty reguły Taylora.

Odpowiedź na drugie pytanie badawcze dotyczące skutków krótkookresowego odejścia od reguły wymagało umieszczenia reguły Taylora w ramach modelu opisującego kształtowanie się inflacji i luki produkcyjnej. Podstawą analiz prowadzonych w rozdziale 4 był nowokeynesistowski model DSGE. Ze względu na silne osadzenie w teorii ekonomii oraz założenie o sztywności cen, modele te stanowią użyteczne narzędzie do analizy skutków polityki pieniężnej (por. np. Clarida, Gali i Gertler, 1999). Model ten zawierał, poza regułą, dwa równania estymowane za pomocą uogólnionej metody momentów - nowokeynesistowską krzywą Phillipsa oraz dynamiczną krzywą IS. Otrzymane wyniki estymacji przeprowadzonych na podstawie danych kwartalnych (za lata 1997-2012) uznano za poprawne ekonomicznie i statystycznie.

Na podstawie skonstruowanego modelu DSGE zbadano skutki krótkookresowego wzrostu stopy procentowej o 0,5 p. proc. ponad wartość wynikającą z reguły (kolejno trzy warianty oszacowane w rozdz. 3). We wszystkich symulacjach nieoczekiwany szok polityki pieniężnej powodował zmniejszenie inflacji i luki produkcyjnej, przy czym maksymalny efekt występował po 3-5 kwartałach. Nieco inną reakcję inflacji i luki obserwowalibyśmy w przypadku szoku oczekiwanego - ogłoszonego na cztery kwartały przed zacieśnieniem. W tym przypadku najsilniejsza reakcja luki występowałaby w okresie, w którym wystąpił szok lub 1 kwartał później (tj. 4-5 kwartałów po zapowiedzi szoku), a inflacji 1 kwartał po wystąpieniu szoku (tj. 5 kwartałów po zapowiedzi), co wiązało się z silnym oddziaływaniem oczekiwań na bieżące wartości inflacji i luki.

Interesujących wniosków dostarcza porównanie wyników symulacji otrzymanych dla poszczególnych wariantów reguły stopy procentowej. Mimo dość znacznych różnic $\mathrm{w}$ oszacowaniach parametrów poszczególnych wariantów reguły polityki pieniężnej, otrzymane reakcje inflacji i luki są bardzo zbliżone. Znaczących różnic w reakcji inflacji i luki nie stwierdzono również w modelu, w którym następowało skokowe przełączanie specyfikacji reguły (zmiany tak rozumianego „reżimu” wyrażono za pomocą procesu Markowa). Na tej podstawie odrzucono hipotezę $\mathrm{H} 4$ o istnieniu różnic $\mathrm{w}$ reakcji inflacji i luki produkcyjnej w modelach z różną regułą.

Rezultaty przeprowadzonych symulacji prowadzą do wniosku, że w modelach DSGE dla Polski wybór specyfikacji dynamicznej reguły stopy procentowej nie jest kluczowy. Można zatem przyjąć, że dalsze badania empiryczne wykorzystujące nowokeynesistowskie modele DSGE mogą ograniczać się do reguły bieżącej, stosunkowo łatwej w estymacji i interpretacji. Ze względu na rosnącą 
popularność modeli DSGE jako narzędzia modelowania gospodarki w krótkim okresie, wydaje się to ważną wskazówką o charakterze „narzędziowym” dla badaczy w przyszłości zajmujących się tą klasą modeli.

Poszukując odpowiedzi na drugie pytanie badawcze porównano także reakcje z dwu scenariuszy: szoku nieoczekiwanego i szoku oczekiwanego w horyzoncie czterech kwartałów. Reakcja inflacji i luki produkcyjnej na szok oczekiwany była silniejsza. Silniejszą, a przy tym widoczną jeszcze przed samym zacieśnieniem polityki pieniężnej, reakcję należy wiązać głównie z silnym oddziaływaniem oczekiwań na bieżące wartości inflacji i luki. Nasze mogą być podstawą twierdzenia, że oczekiwane zacieśnienie polityki pieniężnej zmniejsza koszty dezinflacji mierzone za pomocą współczynnika wyrzeczenia. Natomiast porównanie polityki pieniężnej w warunkach różnych reguł za pomocą kwadratowej funkcji straty banku centralnego wskazuje, że najmniejszych strat wynikających ze zmienności inflacji i luki moglibyśmy się spodziewać przy regule antycypacyjnej (szok nieoczekiwany) lub bieżącej (szok oczekiwany).

$\mathrm{Z}$ uwagi na stosunkowo prostą strukturę modelu (np. gospodarka zamknięta bez udziału państwa i inwestycji; brak sztywności płac; ograniczona rola pieniądza) wnioski z przeprowadzonego badania powinny być traktowane jako warunkowe ze względu na przyjęty model.

Kontynuacja badań może objąć w szczególności: powtórzenie badania skutków szoku polityki pieniężnej dla modeli rozszerzonych o sztywność płac nominalnych, analizę scenariusza szoku oczekiwanego, w którym moment przyszłego zacieśnienia jest obarczony ryzykiem oraz dalsze próby ekonometrycznej analizy reguły antycypacyjnej, w wersji pozwalającej odzwierciedlić reakcję banku centralnego na wiele zmiennych (data-rich environment). 


\section{BIBLIOGRAFIA}

Abel A.B. (1990), Asset prices under habit formation and catching up with the Joneses, „American Economic Review", vol. 80, no. 2.

Acemoglu D. (2008), Introduction to Modern Economic Growth, Princeton University Press, Princeton \& Oxford.

Acocella N. (2002), Zasady polityki gospodarczej, PWN, Warszawa.

Adam K., Billi R. (2005), Optimal monetary policy under commitment with a zero bound on nominal interest rates, ,Journal of Money, Credit, and Banking”, vol. 38, no.7.

Adolfson M., Laséen S., Lindé J., Villani M. (2007), Bayesian estimation of an open economy DSGE model with incomplete pass-through, ,Journal of International Economics”, vol. 72, no. 21.

Amato J.D., Laubach T. (2003), Rule-of-thumb behaviour and monetary policy, „European Economic Review", vol. 47, no. 5.

Andrews D. (1999), Consistent moment selection procedures for generalized method of moments estimation, „Econometrica”, vol. 67, no. 3 .

Athey S., Atkeson A., Kehoe P. (2005), The optimal degree of discretion in monetary policy, „Econometrica", vol. 73 , no. 5 .

Aruoba S. (2008), Data revisions are not well behaved, „Journal of Money, Credit, and Banking”, vol. 40 , no. $2-3$.

Badanie koniunktury gospodarczej (2011), Zeszyt metodologiczny, GUS, Warszawa.

Ball L. (1994), What Determines the Sacrifice Ratio?, [w:] N.G. Mankiw (ed.), Monetary Policy, University of Chicago Press, NBER, www.nber.org/chapters/c8332.

Ball L. (1999), Policy rules for open economies, [w:] J.B. Taylor (ed.), Monetary policy rules, NBER - Business Cycles Series, Chicago.

Baranowski P. (2008a), Problem optymalnej stopy inflacji w modelowaniu wzrostu gospodarczego, Wyd. Biblioteka, Łódź.

Baranowski P. (2008b), Reguła Taylora dla gospodarki polskiej, [w:] A. Krajewska, M. Mackiewicz (red.), Polityka monetarna i fiskalna w okresie akcesji do strefy euro, Wyd. Instytutu Ekonomii UŁ, Łódź.

Baranowski P. (2008c), Wykorzystanie danych typu real-time do oszacowania parametrów reguty Taylora dla Polski, „Wiadomości Statystyczne”, nr 8.

Baranowski P. (2011a), Efekty oczekiwanego i nieoczekiwanego zacieśnienia polityki pieniężnej w świetle hybrydowego modelu DSGE dla gospodarki Polski, „Ekonomista”, nr 3.

Baranowski P. (2011b), Reguła polityki pieniężnej dla Polski - porównanie wyników różnych wariantów specyfikacji, „Oeconomia Copernicana”, $\mathrm{nr} 3$.

Baranowski P., Gałecka-Burdziak E., Górajski M., Malaczewski M., Szafrański G. (2013), Inflacja a mechanizmy aktualizacji cen. Studium dla Polski, Wyd. UŁ i Wyd. Nauk. PWN, Łódź-Warszawa.

Baranowski P., Górajski M., Malaczewski M. (2013), Nowokeynesistowska krzywa Philipsa ze schematem cenotwórczym Calvo, „Ekonomia”, nr 1. 
Baranowski P., Leszczyńska A., Szafrański G. (2010), Krótkookresowe prognozowanie inflacji z uzyciem modeli czynnikowych, „Bank i Kredyt”, vol. 41, nr 4.

Baranowski P., Szafrański G. (2012), Reakcja gospodarki polskiej na szok polityki pieniężnej w matym modelu DSGE - na ile wybór metody estymacji determinuje wyniki?, „Bank i Kredyt”, vol. 43 , $\mathrm{nr} 4$.

Barbaroux N. (2013), Monetary Policy Rule in Theory and Practice, Routledge, London \& New York.

Barro R., Gordon D. (1983a), A positive theory of monetary policy in a natural rate model, „Journal of Political Economy", vol. 91, no. 4.

Barro R., Gordon (1983b), Rules, discretion and reputation in a model of monetary policy, ,Journal Monetary Economics", vol. 12, no. 1.

Barsky R., Sims Ch. (2011), News shocks and business cycles, „Journal of Monetary Economics”, vol. 58 , no. 3 .

Benati L. (2008), Investigating inflation persistence across monetary regimes, „Quarterly Journal of Economics", vol. 123, no. 3.

Bermingham C. (2010), A critical assessment of existing estimates of US core inflation, „Journal of Macroeconomics", vol. 32, no. 4.

Bernanke B., Boivin J. (2003), Monetary policy in a data-rich environment, „Journal of Monetary Economics", vol. 50, no. 3.

Bernanke B., Laubach T., Mishkin F., Posen A. (2001), Inflation Targeting: Lessons from the International Experience, Princeton University Press, Princeton \& Oxford.

Bernanke B., Mishkin F. (1997), Inflation targeting: A new framework for monetary policy, ,Journal of Economic Perspectives", vol. 11, no. 2.

Białek J. (2010), Uogólnione indeksy agregatowe, „Wiadomości Statystyczne”, nr 10.

Blanchard O., Fischer S. (1993), Lectures on Macroeconomics, MIT Press, Cambridge, Mass. \& London.

Blanchard O., Perotti R. (2002), An empirical characterization of the dynamic effects of changes in government spending and taxes on output, „Quarterly Journal of Economics”, vol. 117, no. 4.

Blinder A. (1997), What central bankers could learn from academics and vice-versa, „Journal of Economic Perspective", vol. 11, no. 2.

Blinder A. (2001), Bankowość centralna w teorii i praktyce, CeDeWu, Warszawa.

Blinder A. (2006), Monetary Policy Today: Sixteen Questions and About Twelve Answers, referat wygłoszony na konferencji: Central Banks in $21^{\text {st }}$ Century, Madrid.

Bludnik I. (2010), Nowa synteza neoklasyczna w makroekonomii, „Bank i Kredyt”, vol. 41, nr 2.

Bludnik I. (2012), Neokeynesizm, [w:] Ratajczak M. (red.), Wspótczesne teorie makroekonomiczne, Wyd. UE w Poznaniu, Poznań.

Bohl M., Siklos P., Werner T. (2007), Do central banks react to the stock market? The case of the Bundesbank, „Journal of Banking and Finance”, vol. 31, no. 3.

Boivin J. (2006), Has U.S. monetary policy changed? Evidence from drifting coefficients and realtime data, „Journal of Money, Credit, and Banking”, vol. 38, no. 5.

Boivin J., Ng S. (2006), Are more data always better for factor analysis?, „Journal of Econometrics", vol. 132, no. 1.

Box G.E.P., Draper N.R., Empirical model-building and response surfaces, 1987, http://en.wikiquote. org/wiki/George_E._P._Box. 
Brainard W. (1967), Uncertainty and the effectiveness of monetary policy, „American Economic Review", vol. 57, no. 2.

Brzoza-Brzezina M. (2003), Zagadnienie naturalnej stopy procentowej, „Ekonomista”, nr 4.

Brzoza-Brzezina M. (2008), Korzyści z publikacji projekcji makroekonomicznych i ścieżki stóp procentowych w Polsce, „Bank i Kredyt”, vol. 39, nr 12.

Brzoza-Brzezina M. (2011), Polska polityka pieniężna. Badanie teoretyczne $i$ empiryczne, C.H. Beck, Warszawa.

Brzoza-Brzezina M., Kotłowski J., Miśkowiec A. (2013), How forward-looking are central banks? Some evidence from their forecasts, „Applied Economics Letters”, vol. 20, no. 2.

Brzoza-Brzezina M., Makarski K. (2011), Credit crunch in a small open economy, "Journal of International Money and Finance", vol. 30, no. 7.

Bukowski M., Koloch G., Lewandowski P. (2009), Adaptacyjność gospodarki polskiej do szoków makroekonomicznych, Instytut Badań Strukturalnych, www.ibs.org.pl/site/upload/publikacje/ Adaptacyjnosc_gospodarki_polskiej_IBS_NBP.pdf.

Bukowski M., Dyrda S., Kowal P. (2008), Assessing effects of joining common currency area with large-scale DSGE model: A case of Poland, Instytut Badań Strukturalnych, www.ibs.org.pl/ site/upload/publikacje/working_papers/DSGE_IBS_paper.pdf.

Bussière M., Fratzscher M. (2008), Low probability, high impact: Policy making and extreme events, „Journal of Policy Modeling”, vol. 30, no. 1.

Burns A., Mitchell W. (1946), Measuring Business Cycles, NBER, Book Series Studies in Business Cycles, New York, www.nber.org/books/burn46-1.

Canova F. (2007), Methods of Applied Macroeconomic Research, Princeton University Press, Princeton \& Oxford.

Canova F., Gambetti L. (2009), Structural changes in the US economy: Is there a role for monetary policy?, „Journal of Economic Dynamics and Control”, vol. 33, no. 2.

Canzoneri M.B. (1985), Monetary policy games and the role of private information, „American Economic Review", vol. 75, no. 5.

Caplin A., Suplber D. (1987), Menu costs and the neutrality of money, „Quarterly Journal of Economics", vol. 102, no. 4.

Carstensen K. (2006), Estimating the ECB policy reaction function, „German Economic Review”, vol. 7 , no. 1.

Castro V. (2011), Can central banks' monetary policy be described by a linear (augmented) Taylor rule or by a nonlinear rule?, „Journal of Financial Stability”, vol. 7, no. 4.

Castelnuovo E. (2003), Taylor rules, omitted variables, and interest rate smoothing in the US, „Economics Letters", vol. 81, no. 1.

Castelnuovo E. (2007), Taylor rules and interest rate smoothing in the euro area, „The Manchester School", vol. 75, no. 1.

Cerra V., Saxena S. (2000), Alternative methods of estimating potential output and the output gap An application to Sweden, IMF Working Paper, no. 00/59.

Ciżkowicz P., Hołda M., Rzońca A. (2010), Inflation and corporate investment - a critical survey, „Bank i Kredyt”, vol. 41, nr 6.

Christiano L., Trabandt M., Walentin K. (2010), DSGE Models for Monetary Policy, Northwestern University(mpis), faculty.wcas.northwestern.edu/ lchrist/research/Handbook/ctw_manuscript_main.pdf.

Clarida R., Gali J., Gertler M. (1998), Monetary policy rules in practice. Some international evidence, „European Economic Review”, vol. 42, no. 6. 
Clarida R., Gali J., Gertler M. (1999), The science of monetary policy: A New Keynesian perspective, „Journal of Economic Literature”, vol. 37, no. 4.

Clarida R., Gali J., Gertler M. (2000), Monetary policy rules and macroeconomic stability: Evidence and Some Theory, „Quarterly Journal of Economics”, vol. 115, no. 1.

Cogley T., Sargent T. (2005), Drifts and volatilities: monetary policies and outcomes in the post WWII US, ,Review of Economic Dynamics”, vol. 8, no. 2.

Crespo-Cuaresma J., Gnan E. (2007), The natural rate of interest: Which concept? Which estimation method?, „Journal of Post Keynesian Economics”, vol. 29, no. 4.

Croushore D. (2011), Frontiers of real-time data analysis, „Journal of Economic Literature”, vol. 49 , no. 1.

Davig T., Leeper E. (2007), Generalizing the Taylor Principle, „American Economic Review”, vol. 97 , no. 3 .

Dejong D., Dave Ch. (2007), Structural Macroeconometrics, Princeton University Press, Princeton, Oxford.

Demchuk O., Łyziak T., Przystupa J., Sznajderska A., Wróbel E. (2012), Mechanizm transmisji polityki pieniężnej w Polsce. Co wiemy w 2011 roku?, „Materiały i Studia NBP”, nr 270, www. nbp.pl/publikacje/materialy_i_studia/ms270.pdf.

Dixit A., Stiglitz J. (1977), Monopolistic competition and optimum product diversity, „American Economic Review", vol. 67, no. 3.

Dufour J.-M. (2003), Identification, weak instruments, and statistical inference in econometrics, „Canadian Journal of Economics”, vol. 36, no. 4.

Dolado J., María-Dolores R., Manuel Naveirad M. (2005), Are monetary-policy reaction functions asymmetric?: The role of nonlinearity in the Phillips curve, „European Economic Review”, vol. 49 , no. 2.

Domański Cz. (2001), Analiza dynamiki zjawisk, [w:] Domański Cz. (red.), Metody statystyczne. Teoria i zadania, Wyd. UŁ, Łódź.

Dudek M. (2008), O problemach polityki pieniężnej inaczej (normalnie?), Oficyna Wydawnicza SGH, Warszawa.

Dudek M. (2009), Mikroekonomiczne podstawy dla keynesowskich teorii fluktuacji, Oficyna Wydawnicza SGH, Warszawa.

Dupasquier Ch., Guay A., St-Amant P. (1999), A survey of alternative methodologies for estimating potential output and the output gap, ,Journal of Macroeconomics”, vol. 21, no. 3.

Farmer R., Waggoner D., Zha T. (2011), Minimal state variable solutions to Markov-switching rational expectations models, „Journal of Economic Dynamics and Control”, vol. 35, no. 12.

Favero C. A., Marcellino M., Neglia F. (2005), Principal components at work: the empirical analysis of monetary policy with large data sets, „Journal of Applied Econometrics”, vol. 20, no. 5.

Fic T., Kolasa M., Kot A., Murawski K., Rubaszek M., Tarnicka M. (2005), Model gospodarki polskiej ECMOD, „Materiały i Studia NBP”, nr 194.

Friedman M. (1969), The Optimum Quantity of Money, [w:] M. Friedman (red.), The Optimum Quantity of Money and Other Essays, Aldine Publishing Company, Chicago.

Fuhrer J.C. (2000), Habit formation in consumption and its implications for monetary policy, „American Economic Review”, vol. 90, no. 3.

Fuhrer J.C., Moore G. (1997), Forward-looking behavior and the sability of a conventional monetary policy rule, „Journal of Money, Credit and Banking”, vol. 27, no. 4.

Fuhrer J.C., Rudebusch G.D. (2004), Estimating the Euler equation for output, „Journal of Monetary Economics", vol. 51, no. 6. 
Galati G., Moessner R. (2012), Macroprudential policy - a literature review, „Journal of Economic Surveys", vol. 27, no. 5.

Gali J. (2008), Monetary Policy, Inflation, and the Business Cycle: An Introduction to the New Keynesian Framework, Princeton University Press, Princeton \& Oxford.

Gali J., Gertler M. (1999), Inflation dynamics: A structural econometric analysis, „Journal of Monetary Economics", vol. 44, no. 2.

Gali J., Gertler M., Lopez-Salido D. (2001), European inflation dynamics, „European Economic Review", vol. 45, no. 7.

Gali J., Gertler M., Lopez-Salido D. (2005), Robustness of the estimates of the hybrid New Keynesian Phillips curve, „Journal of Monetary Economics”, vol. 52, no. 6.

Gascoigne J., Turner P. (2004), Asymmetries in Bank of England monetary policy, „Applied Economics Letters", vol. 11, no. 10.

Garcia-Iglesias J. (2007), How the European Central Bank decided its early monetary policy?, „Applied Economics", vol. 39, no. 7.

Gärtner M. (2000), Political macroeconomics: A survey of recent developments, „Journal of Economic Surveys", vol. 14, no. 5.

Gerdesmeier D., Roffia B. (2003), Empirical estimates of reaction function for the euro area, „ECB Working Paper", no. 206.

Gerlach S. (2011), ECB repo rate setting during the financial crisis, „Economics Letters”, vol. 112, no. 2.

Gerlach-Kristen P. (2002), Interest rate smoothing: monetary policy inertia or unobserved variables? A comment on Rudebusch's "term structure evidence on interest-rate smoothing and monetary policy inertia", maszynopis.

Gerlach-Kristen P., Rudolf B. (2010), Financial shocks and the maturity of the monetary policy rate, „Economics Letters”, vol. 107, no. 3.

Giannoni M., Woodford M. (2002), Optimal Interest-Rate Rules, NBER Working Paper, no. 94199420.

Górajski M. (2009), Reduction of absorbing Markov chain, „Annales UMCS. Mathematica”, vol. 63 , no. 1 .

Grabek G. (2006), Statystyczne własności szeregów czasowych inflacji, „Wiadomości Statystyczne", nr 3.

Grabek G., Kłos B., Koloch G. (2010), SOE-PL 2009 - Model DSGE matej otwartej gospodarki estymowany na polskich danych. Specyfikacja, oceny parametrów, zastosowania, „Materiały i Studia NBP", nr 251.

Grabek G., Kłos B., Utzig-Lenarczyk G. (2007), SOE-PL - model DSGE małej otwartej gospodarki estymowany na danych polskich, „Materiały i Studia NBP”, nr 217.

Grabek G., Kłos B. (2012), Podstawowe mechanizmy ekonomiczne modelu DSGE SoePL-2012, „Bank i Kredyt”, vol. 43, nr 6.

Grabowski B. (2000), Polityka pieniężna (tezy), referat niepublikowany.

Gradzewicz M., Kolasa M. (2004), Szacowanie luki popytowej dla gospodarki polskiej przy wykorzystaniu metody VECM, „Bank i Kredyt”, vol. 35, nr 2.

Grzęda Latocha R. (2005), Ekonometryczna analiza determinantów inflacji i stopy procentowej w strefie euro na podstawie danych ankietowych, Wyd. Biblioteka, Łódź.

Grzęda Latocha R., Nerb G. (2003), Modeling short - term interest rates in the euro area using business survey data, referat wygłoszony na konferencji: Annual Meeting of the Verein für Socialpolitik, Zurich. 
Grudkowska S., Paśnicka E. (2007), X-12-ARIMA i TRAMO/SEATS - empiryczne porównanie metod wyrównania sezonowego w kontekście dlugości próby, „Materiały i Studia NBP”, nr 220.

Greene W. (2003), Econometric Analysis, Pearson Education, New York.

Gruszczyński M. (2012), Mikroekonometria. Modele i metody analizy danych indywidualnych, Wolters Kluwer, Warszawa.

Grzęda Latocha R. (2005), Ekonometryczna analiza determinantów inflacji i stopy procentowej w strefie euro na podstawie danych ankietowych, Wyd. Biblioteka, Łódź.

Gwin C., VanHoose D. (2008), Alternative measures of marginal cost and inflation in estimations of New Keynesian inflation dynamics, ,Journal of Macroeconomics”, vol. 30, no. 3.

Hall A.R. (2005), Generalised Method of Moments, Oxford University Press.

Halunga A., Osborn D., Sensier M. (2009), Changes in the order of integration of US and UK inflation, „Economics Letters”, vol. 102, no. 2.

Hałka A., Leszczyńska A. (2011), Wady i zalety wskaźnika cen towarów i ustug konsumpcyjnych - szacunki obciążenia, „Gospodarka Narodowa”, nr 9.

Hansen L.P. (1982), Large sample properties of generalized method of moments estimators, „Econometrica", vol. 50, no. 4.

Hansen L.P., Heaton J., Yaron A. (1996), Finite-sample properties of some alternative GMM estimators, ,Journal of Business and Economic Statistics”, vol. 14, no. 3.

Hardouvelis G.A. (1992), Monetary policy games, inflationary bias, and openness, „Journal of Economic Dynamics and Control", vol. 16, no. 1.

Harris D., Matyas L. (1999), Introduction to the Generalized Method of Moments Estimation, [w:] Matyas L., Generalized Method of Moments Estimation, Cambridge University Press.

Hausman J. (2003), Sources of bias and solutions to bias in the Consumer Price Index, „Journal ofźEconomic Perspectives", vol. 17, no. 1.

Hayford M., Malliaris A. (2004), Monetary policy and the U.S. stock market, „Economic Inquiry”, vol. 42 , no. 3 .

Hertel K., Leszczyńska A. (2013), Uporczywość inflacji i jej komponentów - badanie empiryczne dla Polski, „Przegląd Statystyczny”, nr 2.

Hsing Y. (2005), Did U.S. Monetary policy respond to exchange rates, long-term interest rates, andźthe unemloyment rate gap?, „International Trade Journal”, vol. XIX, no. 1.

Instrumenty polityki pieniężnej... (raporty za lata: od 2001 do 2011), NBP, Warszawa.

Jaimovich N., Rebelo S. (2010), Can news about the future drive the business cycle?, „American Economic Review", vol. 99, no. 4.

Jajuga K., Jajuga T. (2006), Inwestycje, Wyd. Nauk. PWN, Warszawa.

Janecki J. (2011), Reakcja rynkowych stóp procentowych na zmiany stopy procentowej banku centralnego, referat wygłoszony na konferencji NBP pt. „Mechanizm transmisji polityki pieniężnej w Polsce. Co wiemy w 2011 roku?", Warszawa.

Jankiewicz Z., Kołodziejczyk D. (2008), Mechanizmy kształtowania cen w przedsiębiorstwach Polskich na tle zachowań firm ze strefy euro, „Bank i Kredyt”, vol. 39, $\mathrm{nr} 2$.

Judd J., Rudebush G. (1998), Taylor's rule and the Fed: 1970-1997, „Federal Reserve Bank of San Francisco Economic Review", no. 3.

Kapetanios G., Marcellino M. (2010), Factor-GMM estimation with large sets of possibly weak instruments, „Computational Statistics and Data Analysis”, vol. 54, no. 11.

Kauppi H. (2007), Predicting the Fed's Target Rate Decisions, Helsinki Center of Economic Research Discussion Paper, no. 182. 
Kaźmierczak A. (2008), Polityka pieniężna w gospodarce rynkowej, Wyd. Nauk._PWN, Warszawa.

Kim D., Osborn D., Sensier M. (2005), Nonlinearity in the Fed's monetary policy rule, „Journal of Applied Econometrics", vol. 20.

Kleibergen F., Paap R. (2006), Generalized reduced rank tests using the singular value decomposition, „Journal of Econometrics”, vol. 133, no. 1.

Kohn D.L., How should policymakers deal with low-probability, high-impact events?, [w:] Remarks at the European Central Bank Conference on Monetary Policy and Imperfect Knowledge, 2004.

Kokoszczyński R. (2004), Wspótczesna polityka pieniężna w Polsce, PWE, Warszawa.

Kolasa M. (2009), Structural heterogeneity or asymmetric shocks? Poland and the euro area through the lens of a two-country DSGE model, „Economic Modelling”, vol. 26, no. 6.

Kotłowski J. (2006), Funkcje reakcji Rady Polityki Pieniężnej - analiza logitowa, „Bank i Kredyt”, vol. $37, \mathrm{nr} 4$.

Kotłowski J. (2008), Forecasting inflation with dynamic factor model: the case of Poland, Department of Applied Econometrics Working Paper no. 24, Warsaw School of Economics.

Krajewski P. (2006), Metody wyodrębniania strukturalnej i cyklicznej części deficytu, [w:] Józefiak C., Krajewski P., Mackiewicz M., Deficyt budżetowy. Przyczyny i metody ograniczania, PWE, Warszawa.

Krajewski P., Baranowski P. (2006), Wprowadzenie i realizacja strategii bezpośredniego celu inflacyjnego w Polsce, Instytut Ekonomii UŁ, Łódź.

Krajewski P. (2013), Oddziaływanie polityki fiskalnej na wahania koniunktury w Polsce, Wyd. UŁ, Łódź.

Kuchta Z. (2011), Wpływ utraty autonomicznej polityki monetarnej na absorpcje zaburzeń egzogenicznych [w:] Krajewski P. (red.), Gospodarka Polski w perspektywie wstapienia do strefy euro. Ujęcie ilościowe, PWE, Warszawa.

Kydland F., Prescott E. (1977), Rules rather than discretion: The inconsistency of optimal plans, „Journal of Political Economy”, vol. 85, no. 3.

Landreth H., Colander D. (2005), Historia myśli ekonomicznej, Wyd. Nauk. PWN, Warszawa.

Laubach T., Williams J. (2003), Measuring the natural rate of interest, ,Review of Economics andźStatistics", vol. 85, no. 4.

Lebow D., Rudd J. (2003), Measurement error in the consumer price index: where do we stand?, „Journal of Economic Literature”, vol. 41, no. 1.

Lebow D., Rudd J. (2008), Inflation Measurement, [w:] The New Palgrave Dictionary of Economics, eds. S.N. Durlauf, L.E. Blume, Palgrave Macmillan, London.

Leszczyńska A. (2012), Wpływ publikacji projekcji ścieżki stóp procentowych przez bank centralny na efektywność polityki pieniężnej (mpis).

Lohmann S. (1992), Optimal commitment in monetary policy: Credibility versus flexibility, „American Economic Review", vol. 82, no. 1.

Lubik T.A., Marzo M. (2007), An inventory of simple monetary policy rules in a New Keynesian macroeconomic model, „International Review of Economics and Finance”, vol. 16.

Lubik T.A., Schorfheide F. (2007), Do central banks respond to exchange rate movements? A structural investigation, „Journal of Monetary Economics”, vol. 54, no. 4.

Łyko J. (2002), Pomiar i prognozy inflacji, Wyd. AE im O. Langego we Wrocławiu, Wrocław.

Łupiński M. (2012), Short-term forecasting and composite indicators construction with help of dynamic factor models handling mixed frequencies data with ragged edges, „Przegląd Statystyczny", nr 1.

Mackiewicz-Łyziak J. (2010), Wiarygodność banku centralnego, Difin, Warszawa. 
Mackiewicz M. (2006a), Reguły polityki fiskalnej jako metoda ograniczania deficytu, [w:] C. Józefiak, P. Krajewski, M. Mackiewicz, Deficyt budżetowy. Przyczyny i metody ograniczania, PWE, Warszawa.

Mackiewicz M. (2006b), Problem wyboru regut polityki fiskalnej w warunkach gospodarki polskiej, Wyd. UŁ, Łódź.

Mackiewicz M. (2010a), Stabilizacyjna polityka fiskalna w krajach OECD, PWE, Warszawa.

Mackiewicz M. (2010b), Metody weryfikacji stabilności fiskalnej - porównanie własności, „Bank i Kredyt", vol. 41, nr 5.

Maddala G.S. (2006), Ekonometria, Wyd. Nauk. PWN, Warszawa.

Majsterek M. (2008), Wielowymiarowa analiza kointegracyjna w ekonomii, Wyd. UŁ, Łódź.

Małecki W., Sławiński A. (2011), Ewolucja systemów kursowych, [w:] A. Sławiński (red.), Polityka pieniężna, C.H. Beck, Warszawa.

Mankiw N.G., Taylor M.P. (2009), Makroekonomia, PWE, Warszawa.

Mark N.C. (2009), Changing monetary policy rules, learning, and real exchange rate dynamics, „Journal of Money, Credit and Banking”, vol. 41, no. 6.

Martin C., Milas C. (2004), Modelling monetary policy: Inflation targeting in practice, „Economica", vol. 71, no. 282.

McCallum B. (1988), Postwar developments in business cycle theory: A moderately classical perspective, „Journal of Money, Credit and Banking”, vol. 20, no. 3.

McCallum B. (1999), Issues in the Design of Monetary Policy Rules, [w:] J.B. Taylor, M. Woodford (eds.), Handbook of Macroeconomics, vol. 1, Elsevier, Amsterdam.

McCallum B. (2000), Alternative monetary policy rules: A comparison with historical settings for the United States, the United Kingdom and Japan, ,Federal Reserve Bank of Richmond Economic Quarterly", 86/1.

Mehra Y. (1997), A federal funds rate equation, „Economic Inquiry”, vol. XXXV, no. 2.

Metodologia obliczania miar inflacji bazowej (stan: III 2012), Narodowy Bank Polski, Instytut Ekonomiczny - Biuro Cen i Inflacji, www.nbp.pl/home.aspx?f=/statystyka/bazowa/bazowa.htm.

Michałek A. (2009), Znaczenie szacowania potencjalnego PKB w kontekście weryfikacji reguły Taylora, „Acta Universitatis Nicolai Copernici. Nauki Humanistyczno-Społeczne. Ekonomia”, vol. 39, nr 389 .

Milani F., Treadwell J. (2011), The effects of monetary Policy "News" and "Surprises", Department of Economics, University of California-Irvine.

Milas C., Naraidoo R. (2012), Financial conditions and nonlinearities in the European Central Bank (ECB) reaction function: In-sample and out-of-sample assessment, „Computational Statistics \& Data Analysis", vol. 56, no. 1.

Milo W. (1997), Badania ekonometryczne: podstawy metodologiczne, Wyd. UŁ, Łódź.

Mishkin F. (2002), Ekonomika pieniądza, bankowości i rynków finansowych, Wyd. Nauk. PWN, Warszawa.

Mishkin F., [z udziałem:] Eakins S.G. (1998), Financial Markets and Institutions, Addison-Wesley, Boston.

Murray M.P. (2006), Avoiding invalid instruments and coping with weak instruments, „Journal of Economic Perspectives", vol. 20, no. 4.

Moons C., Garretsen H., Bas van Aarle B., Forneroa J. (2007), Monetary policy in the New-Keynesian model: An application to the euro area, „Journal of Policy Modeling”, vol. 29, no. 6. 
Musielak-Linkowska M. (2007), Cel inflacyjny w Polsce. Założenia i realizacja, CeDeWu, Warszawa.

Musielak-Linkowska M. (2008), Strategie polityki pieniężnej, [w:] W. Przybylska-Kapuścińska (red.), Współczesna polityka pieniężna, Difin, Warszawa.

Newey W.K., West K.D. (1987), A simple, positive semi-definite, heteroskedasticity and autocorrelation consistent covariance matrix, „Econometrica”, vol. 55, no. 3.

Osińska M. (2000), Ekonometryczne modelowanie oczekiwań gospodarczych, Wyd. UMK, Toruń.

Orphanides A. (2001), Monetary policy rules based on real-time data, „American Economic Review", vol. 91, no. 4.

Orphanides A. (2003), The quest for prosperity without inflation, „Journal of Monetary Economics”, vol. 50 , no. 3 .

Orphanides A., Williams J. (2006), Monetary policy with imperfect knowledge, „Journal of the European Economic Association", vol. 4, no. 2-3.

Phillips P.C.B., Xiao Z. (1998), A primer on unit root testing, „Journal of Economic Surveys”, vol. 12 , no. 5 .

Polański Z. (2004), Polityka pieniężna, [w:] B. Pietrzak, Z. Polański, B. Woźniak (red.), System finansowy w Polsce, Wyd. Nauk. PWN, Warszawa.

Postek Ł. (2011), Nieliniowy model mechanizmu transmisji monetarnej $w$ Polsce $w$ latach 1999-2009. Podejście empiryczne, „Materiały i Studia NBP”, nr 253.

Przystupa J., Wróbel E. (2006), Looking for an optimal monetary policy rule: The case of Poland under IT framework, „Materiały i Studia NBP”, no. 38.

Qin T., Enders W. (2008), A comparison of the in-sample and out-of-sample properties of linear and nonlinear Taylor rules using real-time data, ,Journal of Macroeconomics”, vol. 30, no. 1.

Raport o inflacji, listopad 2012, NBP, Warszawa.

Razzak W.A. (2003), Is the Taylor rule really different from the McCallum rule?, „Contemporary Economic Policy", vol. 21, no. 4.

Reade J. (2006), The Taylor rule in a real-time cointegrated VAR model of the US, Working Paper, Oxford University.

Reinsdorf M., Triplett J. (2009), A Review of Reviews. Ninety Years of Professional Thinking About the Consumer Price Index, [w:] Diewert E., Price Index Concept and Measurement, University of Chicago Press, Chicago \& London.

Romer D. (2001), Makroekonomia keynesistowska bez krzywej LM, [przedruk z tłumaczeniem na język polski w:] „Gospodarka Narodowa”, nr 5-6.

Romer D. (2011), Advanced Macroeconomics, McGraw-Hill, New York.

Rotemberg J., Woodford M. (1999), Interest-Rate Rules in an Estimated Sticky-Price Model, [w:] J.B. Taylor (ed.), Monetary policy rules, NBER - Business Cycles Series, Chicago.

Rudebush G. (2002), The term structure evidence on interest-rates smoothing and monetary policy inertia, „Journal of Monetary Economics”, vol. 49, no. 6.

Rybiński K. (2007), Globalizacja w trzech odsłonach, Difin, Warszawa.

Sack B. (1998), Does the Fed Act Gradually? A VAR Analysis, „Finance and Economics Discussion Series", Federal Reserve Board Working Paper.

Schmitt-Grohe S., Uribe M. (2009), What's news in business cycles, CEPR Discussion Papers, no. 7201, econpapers.repec.org/RePEc:cpr:ceprdp:7201.

Schmitt-Grohe S., Uribe M. (2012), What's news in business cycles, „Econometrica”, vol. 80, no. 6. 
Shiller R. (1990), The Term Structure of Interest Rates, [w:] B.M. Friedman, F. Hahn (eds.), Handbook of Monetary Economics, Elsevier, Amsterdam.

Shortland A., Stasavage D. (2004), What determines monetary policy in the Franc zone?: Estimating a reaction function for the BCEAO, ,Journal of African economies”, vol. 13, no. 4.

Simons H.-C. (1936), Rules versus authorities in monetary policy, „Journal of Political Economy”, vol. 44.

Sims C., Zha T. (2006), Were there regime switches in U.S. monetary policy?, „American Economic Review", vol. 96, no. 1.

Smets F., Wouters R. (2003), An estimated dynamic stochastic general equilibrium model of the euro area, „Journal of the European Economic Association”, vol. 1, no. 5.

Smets F., Wouters R. (2007), Shocks and frictions in US business cycles: A bayesian DSGE approach, „American Economic Review”, vol. 97, no. 3.

Snowdon B., Vane H., Wynarczyk P. (1998), Wspótczesne nurty teorii makroekonomii, PWN, Warszawa.

Snowdon B., Vane H. (2005), Modern Macroeconomics. Its Origins, Development and Current State, Edward Elgar, Cheltenham, UK \& Northampton, MA.

Statistical Methods for Potential Output Estimation and Cycle Extraction (2003), European Comission, Eurostat, epp.eurostat.ec.europa.eu/cache/ITY_OFFPUB/KS-AN-03-015/EN/KS-AN03-015-EN.PDF.

Stock J., Watson M. (2006), Forecasting with Many Predictors, [w:] G. Ellion, C.W.J. Granger, A. Timmermann (eds.), Handbook of Economic Forecasting, vol. 1, Elsevier, Amstedram.

Stokey N. (2003), "Rules vs. Discretion" after twenty-five years, NBER, Macroeconomics Annual, vol. 17.

Strategia polityki pieniężnej po 2003 roku, NBP, Warszawa.

Sturm J.-E., Den Haan J. (2011), Does central bank communication really lead to better forecasts of policy decisions? New evidence based on a taylor rule model for the ECB, „Review of World Economics", no. 147.

Szafrański G. (2013), Syntetyczne wskaźniki wyprzedzające w prognozowaniu inflacji w Polsce analiza czynnikowa, „Przegląd Statystyczny”, nr 3.

Sznajderska A. (2012), On asymmetric effects in a monetary policy rule. The case of Poland, "National Bank of Poland Working Papers", nr 125, www.nbp.pl/publikacje/materialy_i_studia/125_en.pdf.

Szpunar P. (2000), Polityka pieniężna, PWE, Warszawa.

Sztaudynger J.J. (2002), Prognozowanie cen, [w:] W. Milo (red.), Prognozowanie i symulacja, Wyd. UŁ, Łódź.

Sztaudynger J.J. (2003), Modyfikacje funkcji produkcji $i$ wydajności pracy z zastosowaniami, Wyd. UŁ, Łódź.

Sztaudynger J.J. (2005), Wzrost gospodarczy a kapitat społeczny, prywatyzacja i inflacja, Wyd. Nauk. PWN, Warszawa.

Szyszko M. (2012), Komunikowanie banku centralnego z rynkiem a stabilizowanie oczekiwań inflacyjnych, „Ruch Prawniczy, Ekonomiczny i Socjologiczny”, nr 2.

Svensson L.E.O. (1997), Inflation forecast targeting: Implementing and monitoring inflation targets, „European Economic Review”, vol. 41, no. 6.

Svensson L.E.O. (1999), Inflation targeting: Some extensions, „Scandinavian Journal of Economics", vol. 101, no. 3 . 
Svensson L.E.O. (2000), Open-economy inflation targeting, „Journal of International Economics”, vol. 50 , no. 1 .

Svensson L.E.O. (2002), Inflation targeting: Should it be modelled as an instrument rule or a targeting rule?, „European Economic Review”, vol. 46, no. 4-5.

Svensson L.E.O. (2011), Inflation targeting, [w:] B.M. Friedman, M. Woodford (red.), Handbook of Monetary Economics, vol. 3, Elsevier, Amsterdam.

Svensson L.E.O., Woodford M. (2003), Indicator variables for optimal policy, „, Journal of Monetary Economics", vol. 50, no. 3.

Swamy P.A., Tavlas G., Chang I. (2005), How stable are monetary policy rules: estimating the time varying coefficients in monetary policy reaction function for the US, „Computational Statistics and Data Analysis", vol. 49.

Śmiłowska T., Cynkier A. (2002), Metody uwzględniania jakości w badaniu cen, „Wiadomości Statystyczne", $\mathrm{nr} 8$.

Tae-Hwan K., Mizen P., Chevapatrakul T. (2008), Forecasting changes in UK interest rates, „Journal of Forecasting", vol. 27, no. 1.

Taylor J.B. (1993), Discretion versus Policy Rules in Practice, Carnegie-Rochester Series on Public Policy, vol. 39.

Taylor J.B. (1999), A Historical Analysis of Monetary Policy Rules, [w:] J.B. Taylor (ed.), Monetary Policy Rules, University of Chicago Press.

Taylor J.B. (2000), Using Monetary Rules in Emerging Economies, a revised version of a paper presented at the 75th Anniversary Conference, ,Stabilisation and Monetary Policy: The International Experience", November, Bank of Mexico (mpis).

Taylor J.B. (2001), Role of the exchange rate in monetary-policy rules, „American Economic Review", vol. 91, no. 2.

Taylor M.P., Davradakis E. (2006), Interest rate setting and inflation targeting: Evidence of a nonlinear Taylor rule for the United Kingdom, ,Studies in Nonlinear Dynamics \& Econometrics”, vol. 10 , no. 4.

Temple J. (2000), Inflation and growth: Stories short and tall, „Journal of Economic Surveys”, vol. 14, no. 4.

The Monetary Policy of the ECB (2004), European Central Bank, Frankurt, www.ecb.int.

Tymoczko D. (2011), Operacje otwartego rynku [w:] A. Sławiński (red.), Polityka pieniężna, C.H. Beck, Warszawa.

Wallusch J. (2011), Szoki podażowe i nieokreśloność równowag i przy niestacjonarnej inflacji, „Zeszyty Naukowe UE w Poznaniu", nr 190.

Wallusch J. (2012), How frequently do consumer prices change in transition countries?, „Applied Economics Letters", vol. 19, no. 10.

Wallusch J. (2013), Patrzac na słońce. Nieokreśloność równowagi a polska dezinflacja 1994-2011, Wyd. UE w Poznaniu, Poznań.

Walsh C. (2010), Monetary Theory and Policy, MIT Press, Cambridge, Mass.

Wdowiński P. (2011), Analiza kointegracji kursu PLN/EUR na podstawie modelu równowagi CHEER, „Bank i Kredyt”, vol. 42, nr 1.

Welfe A. (2009), Ekonometria, PWE, Warszawa.

Welfe W. (1966), Indeksy produkcji, PWE, Warszawa.

Welfe W. (2013), Ekonometryczne modelowanie gospodarki narodowej, „Bank i Kredyt”, vol. 44, $\mathrm{nr} 1$. 
Wojtyna A. (1996), Inflacja a wzrost gospodarczy, „Ekonomista”, nr 3.

Wojtyna A. (2000), Ewolucja keynesizmu a główny nurt ekonomii, Wyd. Nauk. PWN, Warszawa.

Wojtyna A. (2004a), Szkice o polityce pieniężnej, PWE, Warszawa.

Wojtyna A. (2004b), Bank centralny w świetle teorii agencji, „Gospodarka Narodowa”, nr 9.

Wojtyna A. (2004c), Skuteczność polityki pieniężnej, cykl wykładów dziekańskich „Gospodarka i społeczeństwo", Wyd. UŁ, Łódź.

Woodford M. (2003), Interest and Prices: Foundations of a Theory of Monetary Policy, Princeton University Press, Princeton \& Oxford.

Woźniak P. (2002), Inflacja bazowa, CASE, Warszawa.

Wróblewska K. (2013), Koszty dezinflacji - analiza teoretyczna i empiryczna, praca licencjacka napisana w Katedrze Ekonometrii UŁ pod kierunkiem P. Baranowskiego, Łódź.

Vetlov I., Hlédik T., Jonsson M., Kucsera H., Pisani M. (2011), Potential output in DSGE models, ECB Working Paper, no. 1351.

Vasicek B. (2009), Inflation dynamics and the New Keynesian Phillips curve in EU-4, William Davidson Institute Working Paper, no. 971.

Verbeek M. (2012), Modern Guide to Econometrics, John Wiley \& Sons, The Atrium, etc.

Yates T. (2004), Monetary policy and the zero bound to interest rates: A review, „Journal of Economic Surveys", vol. 18, no. 3.

Założenia polityki pieniężnej... (różne wydania), NBP, Warszawa.

Zawadzka Z. (1997), Systemy bankowe. Przykład RFN, Studia Finansowo-Bankowe SGH, Poltext, Warszawa.

Ziarko-Siwek U. (2013), Efekt ogłoszeń jako wyraz przejrzystości polityki pieniężnej, „Ekonomista", nr 1.

Zienkowski L., Cywil E. (1992), Indeksy wolumenu produktu krajowego brutto (różne metody szacunku), „Wiadomości Statystyczne”, nr 10. 


\section{OD REDAKCJI}

Dr Paweł Baranowski jest adiunktem w Katedrze Ekonometrii Uniwersytetu Łódzkiego. Jego zainteresowania naukowe skupiają się wokół makroekonomii i ekonometrii stosowanej, specjalizuje się w analizie polityki pieniężnej. W roku 2007 obronił pracę doktorską pt. Problem optymalnej stopy inflacji w modelowaniu wzrostu gospodarczego, napisaną pod kierunkiem prof. Jacka J. Sztaudyngera. Za pracę tę otrzymał II Nagrodę im. prof. Witolda Kuli. Ponadto trzykrotnie otrzymał Nagrody Rektora UŁ za działalność naukową (indywidualnie i zespołowo). Jest autorem lub współautorem ponad 35 prac naukowych publikowanych m.in. w: „Ekonomiście”, „Banku i Kredycie”, „Gospodarce Narodowej” i „Przeglądzie Statystycznym”. Brał udział jako wykonawca lub kierownik w 5 projektach badawczych finansowanych przez MN i SW oraz NCN.

Dr Paweł Baranowski od 2009 roku pracuje także w Instytucie Ekonomicznym NBP, gdzie zajmuje się analizą i prognozowaniem szeroko rozumianych procesów inflacyjnych. 